\author{
UNIVERSIDADE DE SÃO PAULO \\ ESCOLA DE ARTES, CIÊNCIAS E HUMANIDADES \\ PROGRAMA DE PÓS-GRADUAÇÃO EM TÊXTIL E MODA
}

FABIO CAMPOS FATALLA

Proposta de metodologia para classificação fiscal de mercadorias têxteis na Nomenclatura Comum do Mercosul

SÃO PAULO

2017 


\title{
PROPOSTA DE METODOLOGIA PARA CLASSIFICAÇÃO FISCAL DE MERCADORIAS TÊXTEIS NA NOMENCLATURA COMUM DO MERCOSUL
}

\author{
Versão corrigida
}

Dissertação apresentada à Escola de Artes Ciências e Humanidades da Universidade de São Paulo para obtenção do título de Mestre em Ciências do Programa de Pós-Graduação em Têxtil e Moda.

Versão corrigida contendo as alterações solicitadas pela comissão julgadora em 15/09/2017. A versão original encontra-se em acervo reservado na Biblioteca da $\mathrm{EACH} / \mathrm{USP}$ e na Biblioteca Digital de Teses e Dissertações da USP (BDTD), de acordo com a Resolução CoPGr 6018, de 13 de outubro de 2011.

Área de Concentração: Têxtil e Moda

Orientadora: Profa. Dra. Regina Aparecida Sanches 
Autorizo a reprodução e divulgação total ou parcial deste trabalho, por qualquer meio convencional ou eletrônico, para fins de estudo e pesquisa, desde que citada a fonte.

CATALOGAÇÃO-NA-PUBLICAÇÃO

(Universidade de São Paulo. Escola de Artes, Ciências e Humanidades. Biblioteca)

Fatalla, Fabio Campos

Proposta de metodologia para classificação fiscal de mercadorias têxteis na nomenclatura comum do Mercosul / Fabio Campos Fatalla ; orientadora, Regina Aparecida Sanches. 2017

$139 \mathrm{f}$. : il

Dissertação (Mestrado em Ciências) - Programa de PósGraduação em Têxtil e Moda, Escola de Artes, Ciências e Humanidades, Universidade de São Paulo Versão corrigida

1. Indústria têxtil. 2. Produtos - Classificação. 3.

Mercosul. I. Sanches, Regina Aparecida, orient. II. Título.

CDD 22.ed. -677 
Nome: FATALLA, Fabio Campos

Título: Proposta de metodologia para classificação fiscal de mercadorias têxteis na Nomenclatura Comum do Mercosul

Dissertação apresentada à Escola de Artes, Ciências e Humanidades da Universidade de São Paulo para obtenção do título de Mestre em Ciências do Programa de Pós-Graduação em Têxtil e Moda

Aprovado em:19/10/2017

\section{Banca Examinadora}

Prof. Dr. João Paulo Pereira Instituição: Escola de Artes, Ciências e Marcicano Humanidades Universidade

Julgamento: Aprovado de São Paulo

Prof. Dr. Nicolas Theophanis Instituição: Centro Universitário Boukouvalas Anhanguera de São Paulo

Julgamento: Aprovado

Prof. Dra. Adriana Yumi Sato Instituição: Centro Universitário Nossa Duarte Senhora do Patrocínio

Julgamento: Aprovado 


\section{DEDICATÓRIA}

Dedico esse trabalho a minha esposa Adriana Fatalla e meus filhos Henrique Fatalla, Guilherme Fatalla e Helena Fatalla, que de muitas formas me ajudaram e incentivaram para que fosse possível a concretização deste trabalho. Aos meus colegas por estarem sempre presentes nos momentos difíceis. 


\section{AGRADECIMENTOS}

À Escola de Artes Ciências e Humanidades (EACH/USP), pela oportunidade de ter realizado este curso de Mestrado.

A minha orientadora, Professora Doutora Regina Aparecida Sanches pela disponibilidade, confiança e pela autonomia que me deu durante a realização deste trabalho. Gostaria de agradecer a oportunidade que me ofereceu em realizar a dissertação numa área tão emergente como a aduaneira.

Ao meu grande amigo Professor Fernando Barros de Vasconcelos, pelo auxílio prestado na orientação para as melhores vias a seguir na realização do trabalho.

A minha esposa e meus filhos, por estarem sempre presentes, nos meus melhores e piores momentos, me ajudaram a caminhar e concluir esta jornada preenchendo meus dias com amor, carinho, paciência e confiança.

Aos Engenheiros Fernanda Gomes de Vasconcelos, Guilherme Venâncio de Oliveira e Allan Baptista Reis, pela disponibilidade em auxiliar e aconselhamentos.

Aos meus amigos agradeço toda a compreensão. 


\section{RESUMO}

FATALLA, Fabio Campos. Proposta de metodologia para classificação fiscal de mercadorias têxteis na Nomenclatura Comum do Mercosul. 2017. 139 f. Dissertação (Mestrado em Ciências) - Escola de Artes, Ciências e Humanidades, Universidade de São Paulo, São Paulo, 2017. Versão corrigida.

A Classificação Fiscal de Mercadorias está entre as principais dificuldades do dia a dia das empresas uma vez que é fundamental na determinação de vários impostos e taxas, notadamente, na apuração dos tributos envolvidos nas operações de importação e exportação. Com o aumento das operações de exportação e, principalmente, de importação nos últimos anos na área têxtil, a correta classificação de mercadorias tornou-se tema de fundamental importância no setor. Considerando o exposto, esse trabalho teve por objetivo analisar a classificação de materiais têxteis na Nomenclatura Comum do Mercosul (NCM) e desenvolver uma metodologia que possibilite e facilite a sua correta classificação. Através da identificação de pontos chaves na classificação dos produtos foram construídos fluxogramas lógicos de decisão que permitiram chegar à correta classificação de quatro produtos escolhidos como pilotos mostrando a aplicabilidade da metodologia proposta

Palavras-chave: Classificação Fiscal de Têxteis. Sistema Harmonizado. NCM. 


\section{ABSTRACT}

FATALLA, Fabio Campos. Proposal of a methodology for tax classification of textile goods in the Mercosur Common Nomenclature. 2017. 139 f. Dissertação (Master of Science) - Escola de Artes, Ciências e Humanidades, Universidade de São Paulo, São Paulo, 2017. Corrected version.

Fiscal Goods Classification is one of the main difficulties in companies' day-today operations since it is fundamental in the determination of many tax and fees, in particular, in the determination of the taxes involved in import and export operations. With the increase of the export operations and, mainly, of the import in the last years in the textile area, the correct classification of commodities became a subject of fundamental importance in the sector. Considering the above, this work aimed to analyze the classification of textile materials in the Mercosul Common Nomenclature (NCM) and to develop a methodology that allows and facilitates its correct classification. By means of the identification of key points in the classification of the products, logical decision flow diagrams were constructed that allowed to reach the correct classification of four products chosen as pilots showing the applicability of the proposed methodology.

Keywords: Textile Tax Classification, Harmonized System, NCM 


\section{LISTA DE FIGURAS}

Figura 1 - Importações nacionais de têxteis (em US\$ milhões) ……......................19

Figura 2 - Origem das importações nacionais de têxteis ......................................19

Figura 3 - Importações nacionais de têxteis por tipo de material ............................19

Figura 4 - Importações nacionais de confeccionados (em US\$ milhões) ................20

Figura 5 - Origem das importações nacionais de confeccionados ........................20

Figura 6 - Importações nacionais de confeccionados por tipo de produto ................21

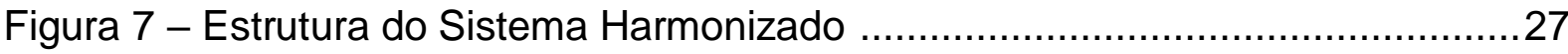

Figura 8 - Organização do Sistema Harmonizado ............................................28

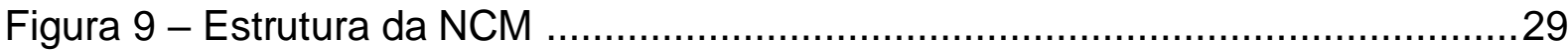

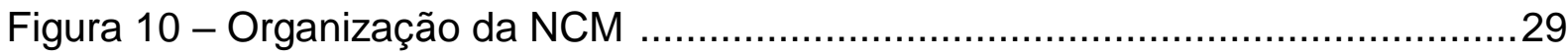

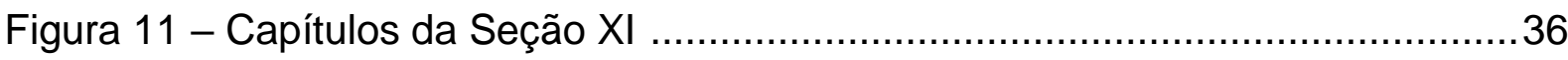

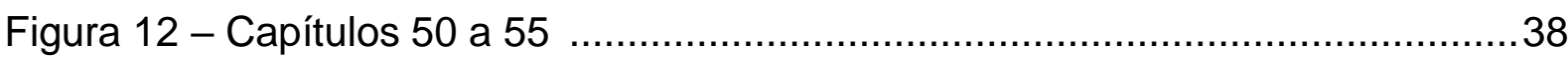

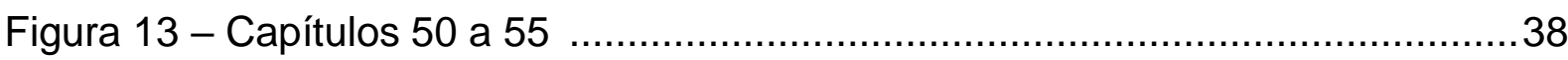

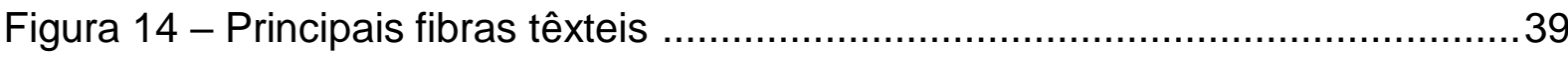

Figura 15 - Classificação e siglas das fibras têxteis segundo a ABNT ....................39

Figura 16 - Principais apresentações dos materiais têxteis ..................................40

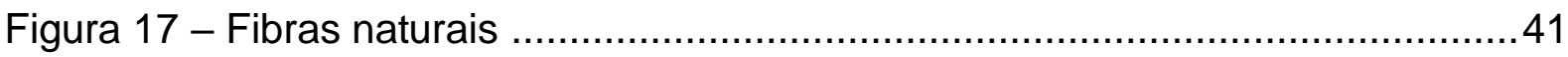

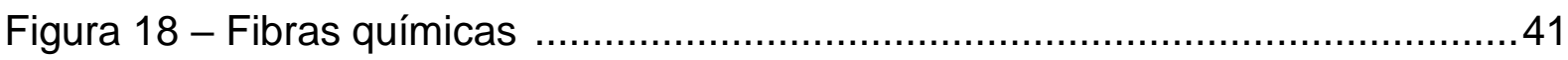

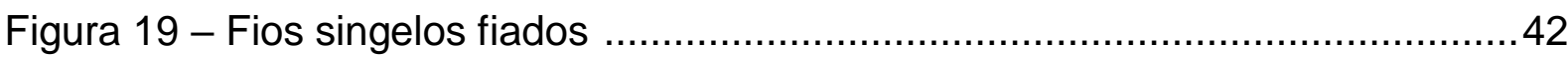

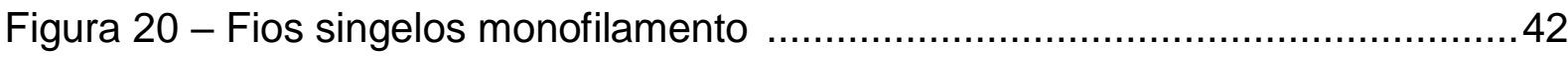

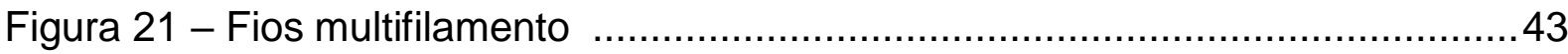

Figura 22 - Fios multifilamento convencional e microfibra ...................................43

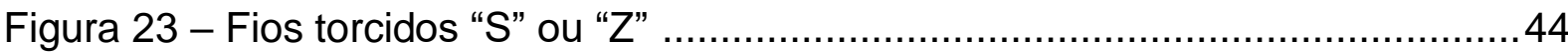

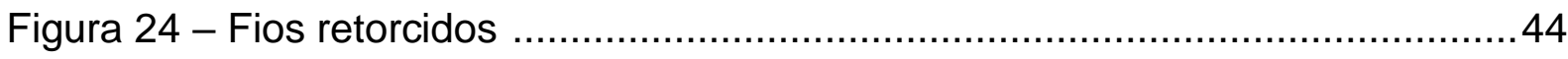

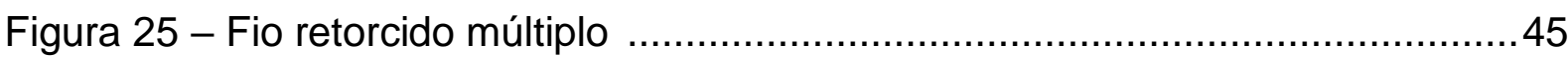

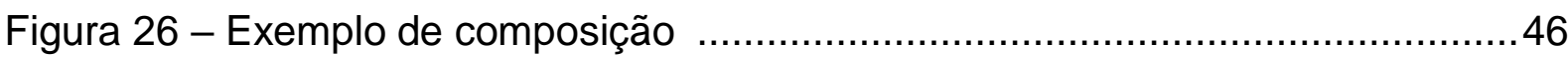

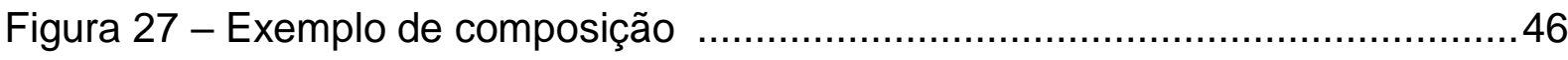

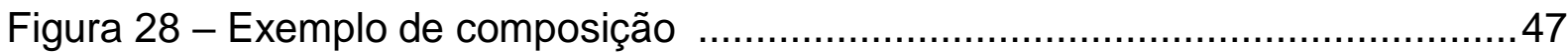

Figura 29 - Exemplo de composição …………...........................................47

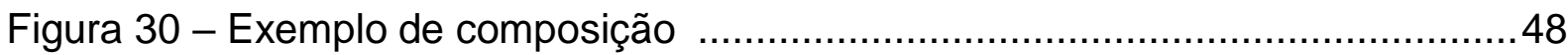

Figura 31 - Exemplo de composição .......................................................... 48 


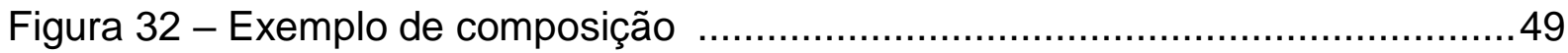

Figura 33 - Fios acondicionados para venda no varejo ...................................... 49

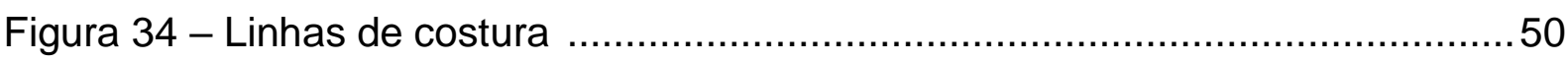

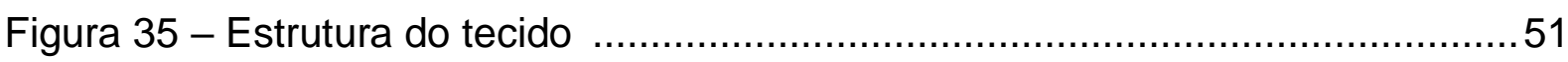

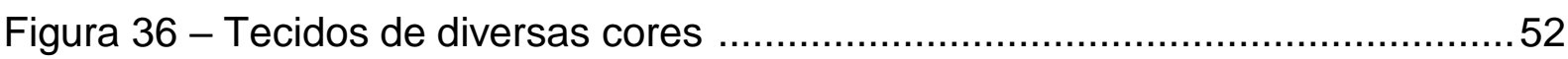

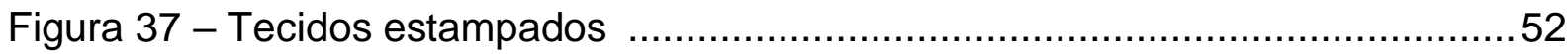

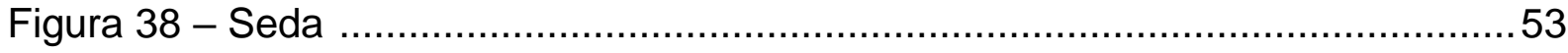

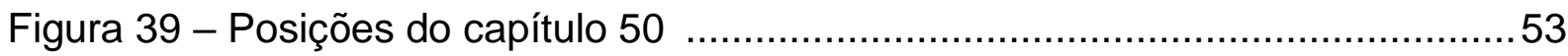

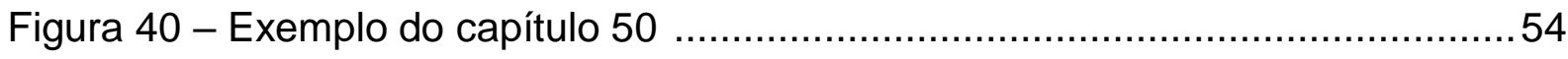

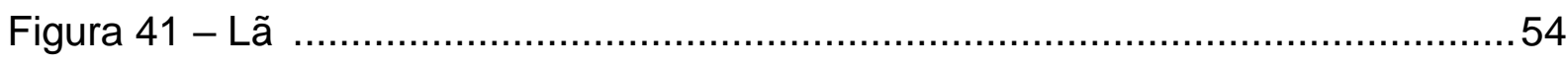

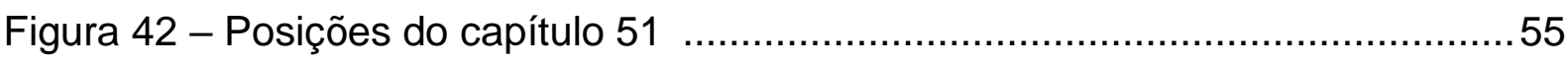

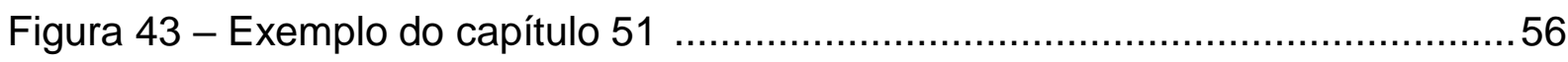

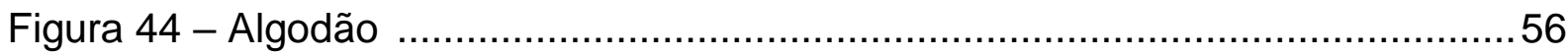

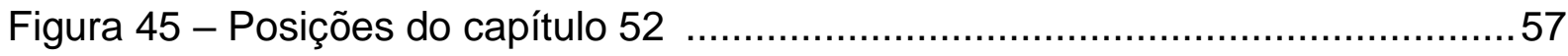

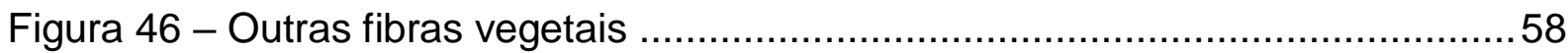

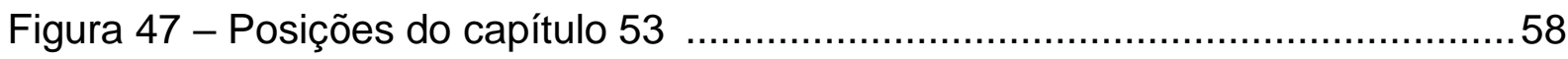

Figura 48 - Filamentos sintéticos e artificiais …………...................................59

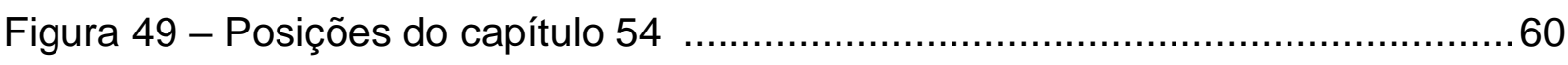

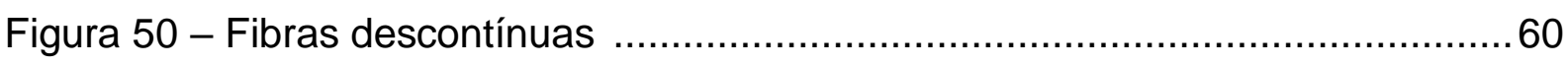

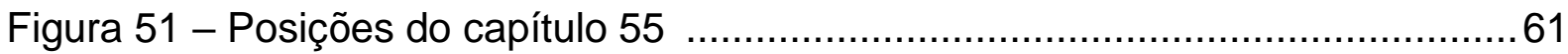

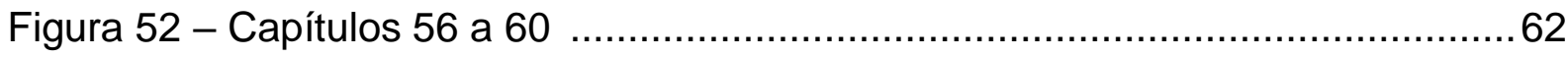

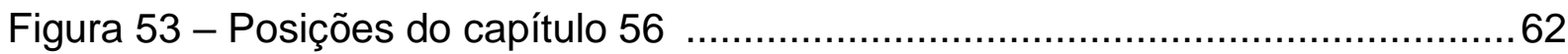

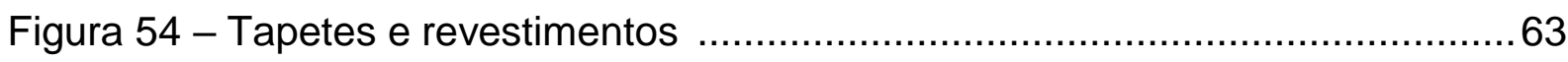

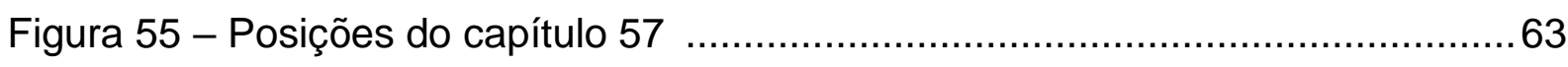

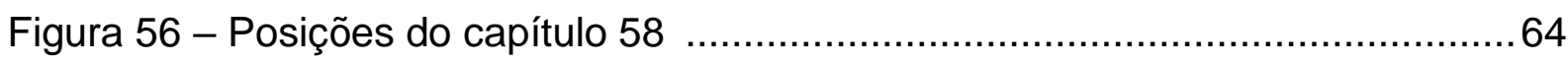

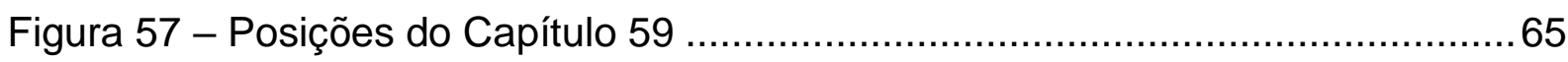

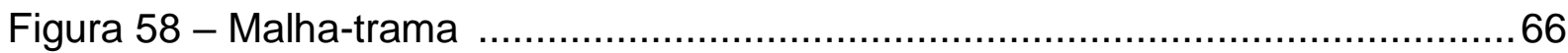

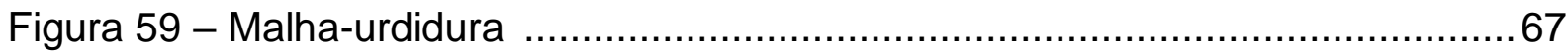

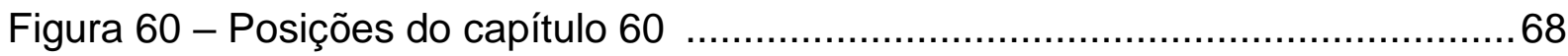

Figura 61 - Imitação de renda em malha-urdidura raschel .....................................69

Figura 62 - Outros tecidos de malha - posição 60.06 ..........................................69

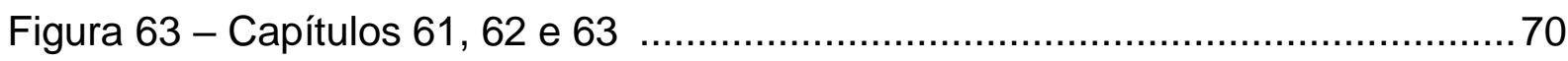

Figura 64 - Posições do capítulo 61 ............................................................ 72

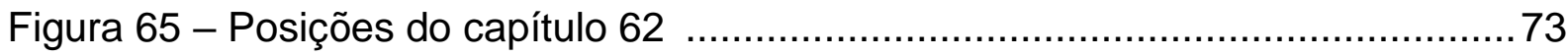




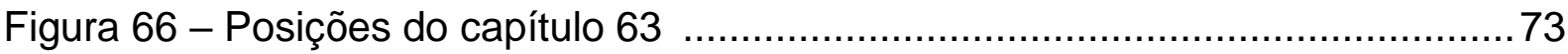

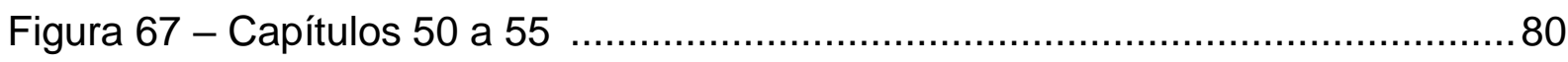

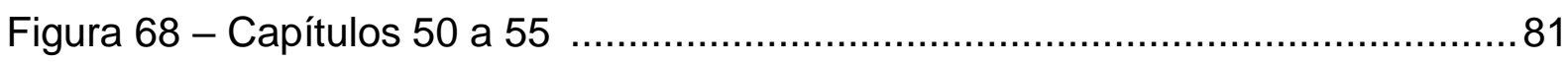

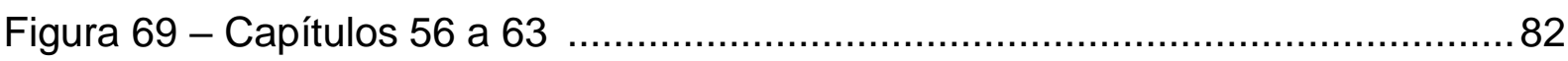

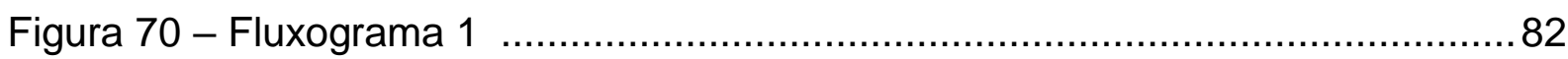

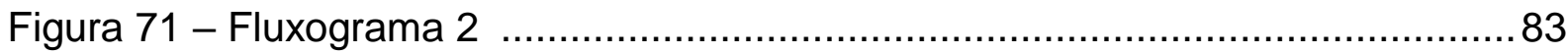

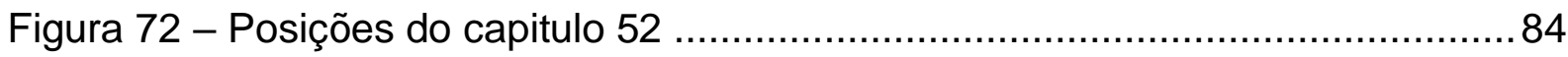

Figura 73 - Fluxograma de posições do capitulo 52 (1) ……............................. 84

Figura 74 - Fluxograma de posições para fios de algodão (2) ……......................... 85

Figura 75 - Fluxograma de subposições para fios de algodão - nível 1 ..................86

Figura 76 - Fluxograma de subposições para fios de algodão - nível 2 .................. 86

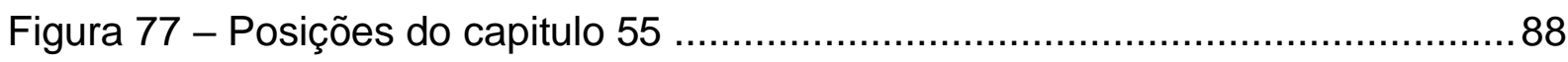

Figura 78 - Fluxograma de posições do capítulo 55 ......................................... 89

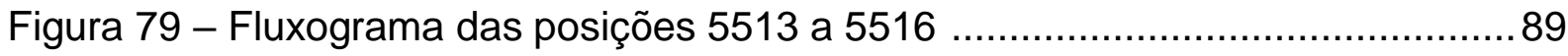

Figura 80 - Fluxograma para definição do primeiro dígito de subposição para a

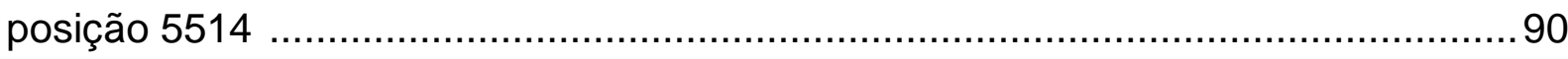

Figura 81 - Fluxograma para definição do segundo dígito de subposição para a

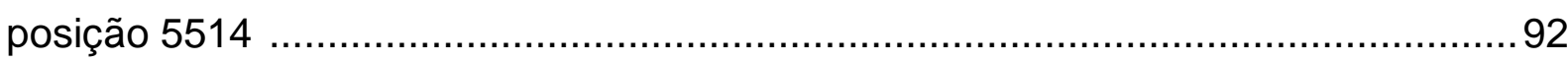

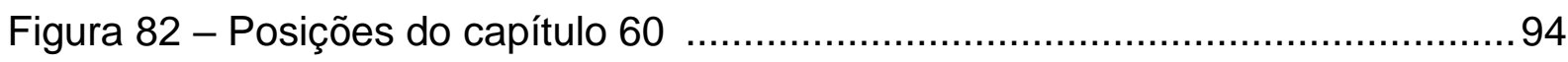

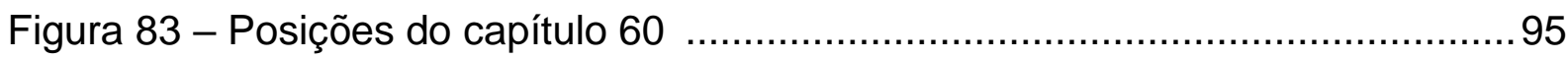

Figura 84 - fluxograma de posições do capítulo 60 ...........................................96

Figura 85 - fluxograma de posições do capítulo 60 ..........................................97

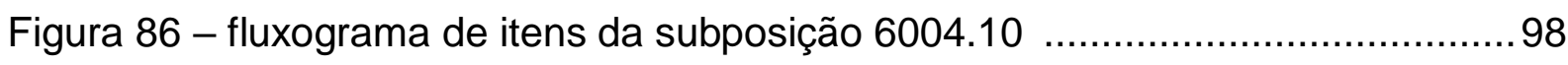

Figura 87 - fluxograma de itens da subposição 6004.10 .....................................99

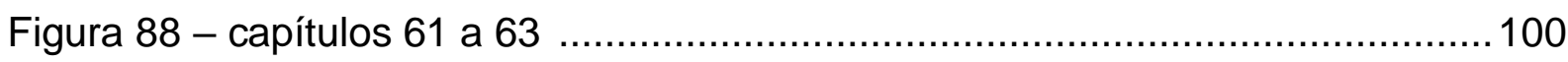

Figura 89 - fluxograma para os capítulos 61 a 63 ...............................................101

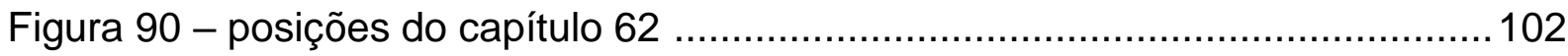

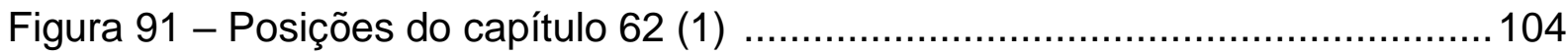

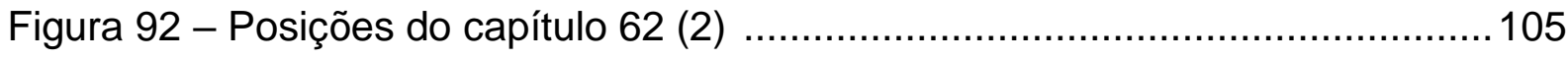

Figura 93 - Subposições da posição 6204 (1ํ dígito) ……………......................106

Figura 94 - Subposições da posição 6204 ( $2^{\circ}$ dígito) .........................................107

Figura 95 - Classificação de fio de algodão - grupo de capítulos .........................109

Figura 96 - Classificação de fio de algodão - capítulo ......................................110

Figura 97 - Classificação de fio de algodão - posição (1) ..................................110 
Figura 98 - Classificação de fio de algodão - posição (2) 111

Figura 99 - Classificação de fio de algodão - subposição nível 1 112

Figura 100 - Classificação de fio de algodão - subposição nível 2 113

Figura 101 - Classificação de tecido - grupo de capítulos 116

Figura 102 - Classificação de tecido - capítulo 116

Figura 103 - Classificação de tecido - grupo de posições 117

Figura 104 - Classificação de tecido - posição 118

Figura 105 - Classificação de tecido - primeiro algarismo da subposição 119

Figura 106 - Classificação de tecido - segundo algarismo da subposição 120

Figura 107 - Classificação de malha de urdume - capítulo 123

Figura 108 - Classificação de malha de urdume - posição 124

Figura 109 - Classificação de malha de urdume - subposição 125

Figura 110 - Classificação de malha de urdume - subposição 126

Figura 111 - Classificação de malha de urdume - subposição 127

Figura 112 - Classificação de vestido de algodão - capítulo 128

Figura 113 - Classificação de vestido de algodão - grupo de posições 130

Figura 114 - Classificação de vestido de algodão - posição 131

Figura 115 - Classificação de vestido de algodão - primeiro dígito da subposição

Figura 116 - Classificação de vestido de algodão - segundo dígito da subposição 


\section{LISTA DE ABREVIATURAS}

ABNT - Associação Brasileira de Normas Técnicas

ADE COANA - Ato Declaratório Executivo Coordenação-Geral de Administração Aduaneira

BNDS - Banco Nacional de Desenvolvimento Econômico e Social CAMEX - Câmara do Comércio Exterior CCA - Conselho de Cooperação Aduaneira $\mathrm{CUCl}$ - Classificação Uniforme para o Comércio Internacional IEMI - Instituto de Estudos e Marketing Industrial IPI - Imposto sobre Produtos Industrializados MDIC - Ministério do Desenvolvimento da Indústria e do Comércio NAB - Nomenclatura Aduaneira de Bruxelas NCCA - Nomenclatura do Conselho de Cooperação Aduaneira NCM - Nomenclatura Comum do Mercosul

NESH - Notas Explicativas do Sistema Harmonizado

OMA - Organização Mundial de Aduanas

RGC - Regras Gerais Complementares

$\mathrm{SH}$ - Sistema Harmonizado

TEC - Tarife Externa Comum 
SUMÁRIO

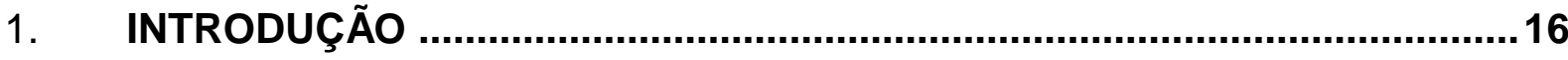

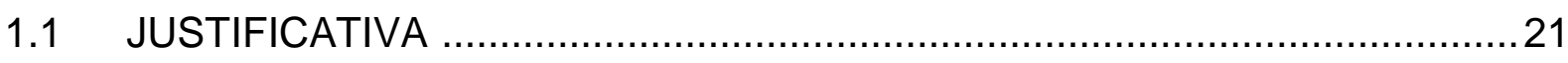

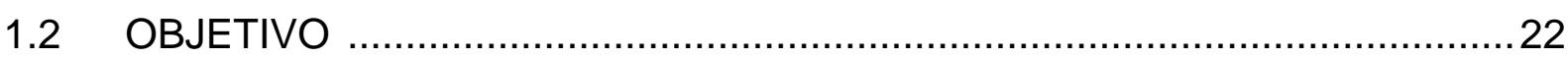

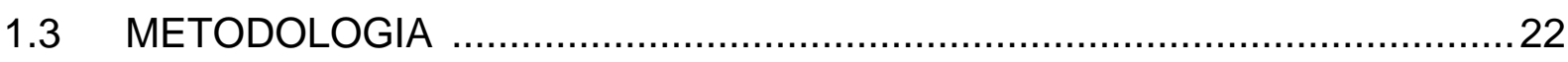

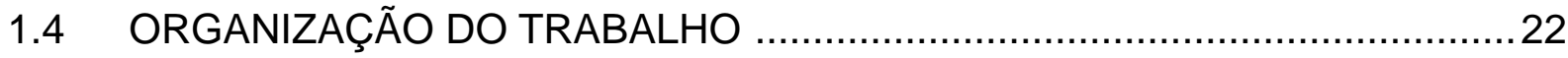

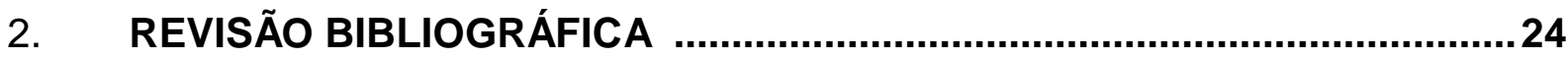

2.1 A CLASSIFICAÇÂO FISCAL DE MERCADORIAS ……............................24

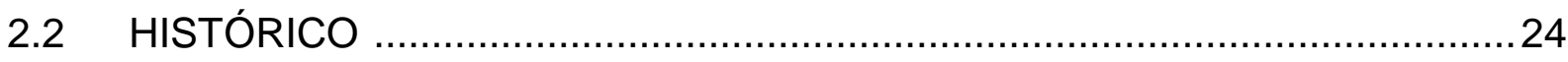

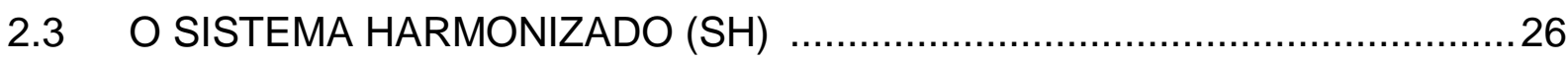

2.4 NOMENCLATURA COMUM DO MERCOSUL (NCM) ...............................28

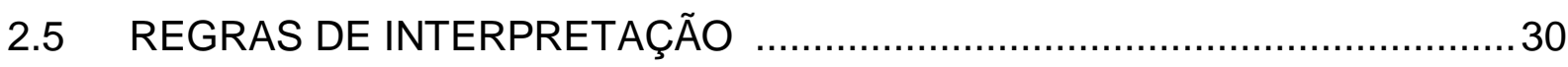

2.5.1 Regras Gerais do sistema harmonizado ..................................................30

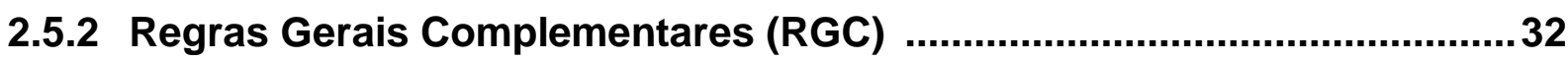

2.5.3 Notas Explicativas do Sistema Harmonizado (NESH) ..............................33

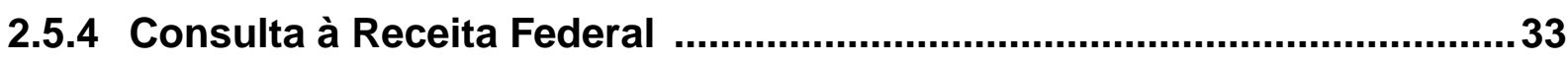

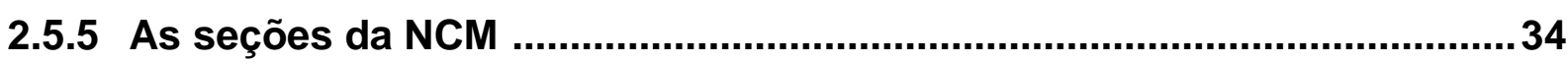

2.6 A SEÇÃO XI DA NCM: MATERIAIS TÊXTEIS E SUAS OBRAS ...................35

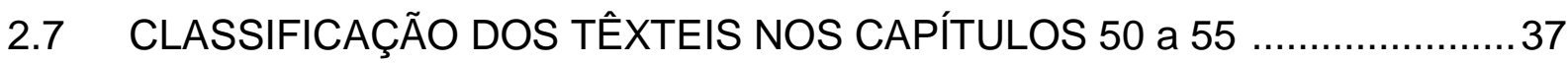

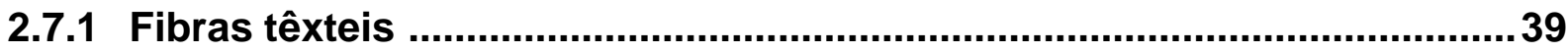

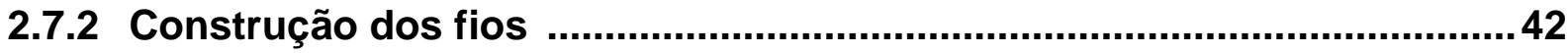

2.7.3 Considerações sobre a classificação dos têxteis nos capítulos 50 a 5545

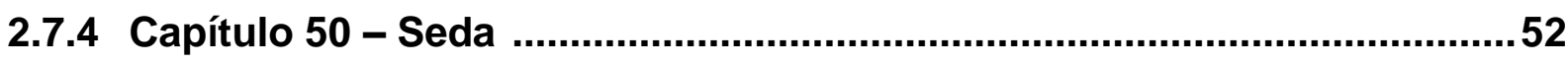

2.7.5 Capítulo 51 - Lã, pelos finos ou grosseiros; fios e tecidos de crina. ......54

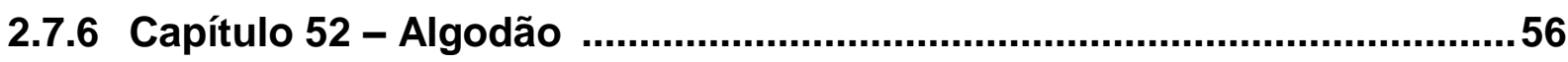

2.7.7 Capítulo 53 - Outras fibras têxteis vegetais; fios de papel e tecidos de fios de papel

2.7.8 Capítulo 54 - Filamentos sintéticos ou artificiais; lâminas e formas semelhantes de matérias têxteis sintéticas ou artificiais .............59

2.7.9 Capítulo 55 - Fibras sintéticas ou artificiais, descontínuas ....................60

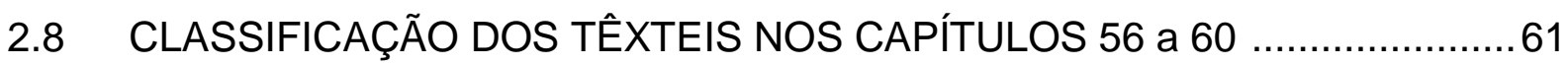


2.8.1 Capítulo 56 - Pastas (ouates), feltros e falsos tecidos; fios especiais; cordéis, cordas e cabos; artigos de cordoaria. 62

2.8.2 Capítulo 57 - Tapetes e outros revestimentos para pisos (pavimentos), de matérias têxteis 63

2.8.3 Capítulo 58 - Tecidos especiais; tecidos tufados; rendas; tapeçarias; passamanarias; bordados

2.8.4 Capítulo 59 - Tecidos impregnados, revestidos, recobertos ou estratificados; artigos para usos técnicos de matérias têxteis .64

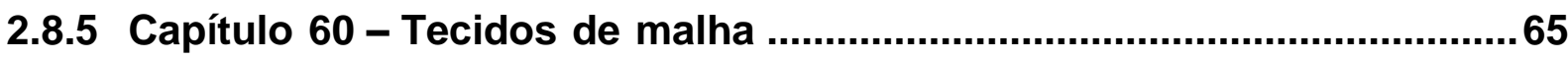

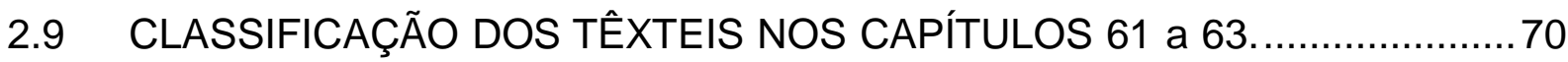

2.9.1 Capítulo 61 - vestuário e seus acessórios, de malha .............................71

2.9.2 Capítulo 62 - vestuário e seus acessórios exceto malha .....................72

2.9.3 Capítulo 63 - Outros Artefatos Têxteis Confeccionados; Sortidos; Artefatos de Matérias Têxteis, Calçados, Chapéus e Artefatos de uso semelhante, usados; Trapos . .73

2.10 ATO DECLARATÓRIO EXECUTIVO (ADE) COANA 22 ….........................74

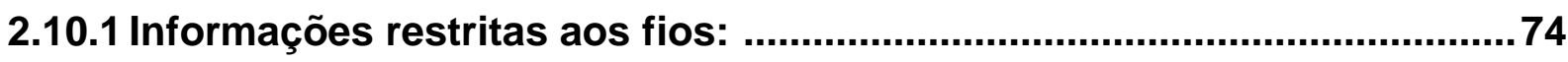

2.10.2 Informações restritas aos tecidos: .............................................................

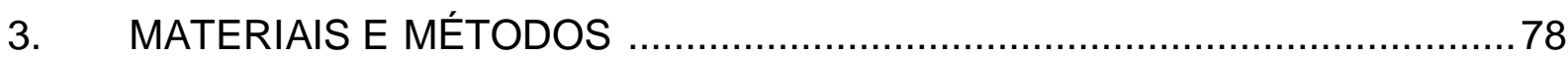

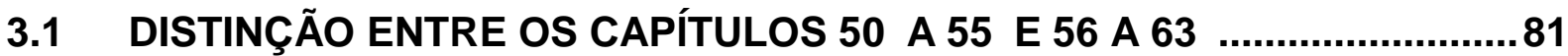

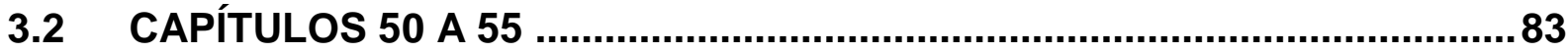

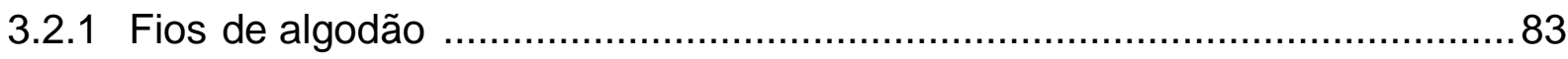

3.2.2 Tecido de fibras sintéticas descontinuas tinto ................................................. 88

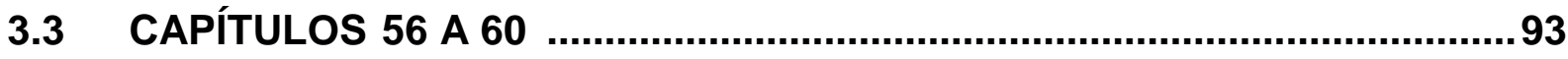

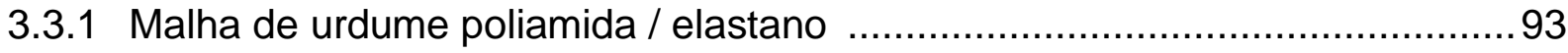

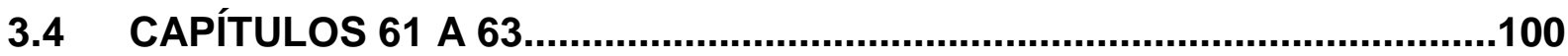

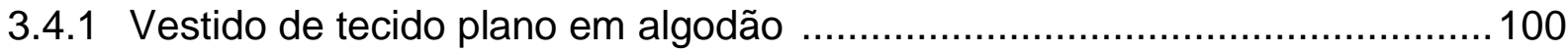

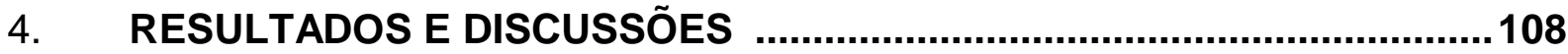

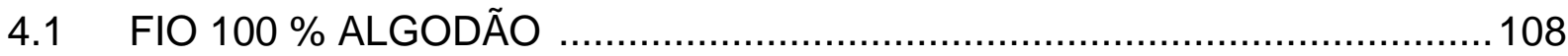

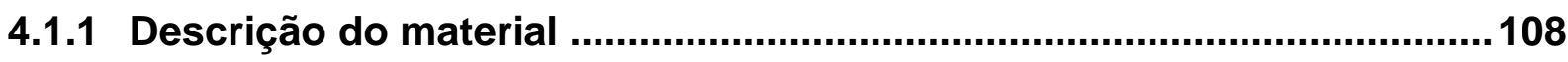

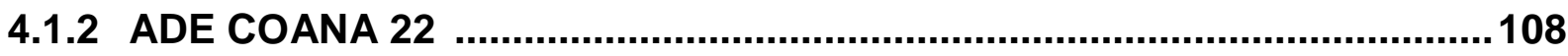

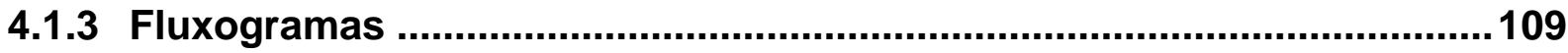

4.2 TECIDO PLANO POLIÉSTER/ALGODÃO ….........................................112

4.2.1 Descrição do material .........................................................................112 
4.2.2 ADE COANA 22 114

4.2.3 Fluxogramas 115

4.3 TECIDO DE MALHA POR URDUME POLIAMIDA/ELASTANO 120

4.3.1 Descrição do material 120

4.3.2 ADE COANA 22 120

4.3.3 Fluxogramas 122

4.4 VESTIDO DE TECIDO PLANO DE ALGODÃO 127

4.4.1 Descrição do material 127

4.4.2 Fluxogramas 128

5. CONCLUSÃO 134

REFERÊNCIAS 136 


\section{INTRODUÇÃO}

No Brasil, a modernização do parque têxtil tomou forma desde os anos 90 . Os principais reflexos retrataram-se no aumento das importações de produtos e de equipamentos para o setor, da mesma forma que na redução do número de empresas e de empregos (OLIVEIRA e MEDEIROS, 1996).

As medidas com destino ao apoio à abertura comercial e incentivo da produção industrial nacional do início da década de 1990, bem como as políticas posteriores de estabilização da inflação introduzidas pelo Plano Real causaram transformações consideráveis na produção da indústria têxtil brasileira. Os impactos da abertura da economia brasileira e do aumento da concorrência externa a partir da abertura comercial, bem como a estabilização da moeda, que ampliou o consumo da população de renda mais baixa, levaram a transformações estruturais na cadeia têxtil nacional

A abertura comercial intensificou a busca de interesses entre os participantes deste contexto comercial. Esta disparidade tem origem nos produtos do setor que, por terem características muito homogêneas dos produtos intermediários, são tratados no mercado quase como produtos finais (MASSUDA, 2002).

De acordo com Antero (2006), a elevação da competitividade das cadeias produtivas é um propósito complexo, que envolve políticas de natureza sistêmica, em boa medida dependentes de iniciativas do governo, de natureza estrutural, de âmbito setorial, e ações de domínio empresarial relativas aos fatores microeconômicos.

Nas últimas décadas, nota-se uma tendência à crescente internacionalização da cadeia global nessas indústrias, com papel essencial exercido pelas grandes empresas compradoras internacionais. Esta nova realidade de organização da cadeia global exerceu efeitos importantes sobre a participação dos diferentes países no comércio internacional têxtil.

Segundo Coutinho, Hiratuka e Sabbatini (2003), os desafios enfrentados pelo Brasil para a sustentação do seu desenvolvimento econômico estão ligados à reestruturação de sua inserção internacional. Por conseguinte, um objetivo prioritário a ser perseguido pela gestão da política econômica deveria ser o aumento de competitividade do setor produtivo, contribuindo para que o Brasil reestruture sua pauta exportadora e ocupe melhores espaços na economia internacional.

A balança comercial do setor têxtil brasileiro sofreu duro impacto com a abertura 
comercial e, se antes apresentava saldo positivo, embora decrescente, passou a ter déficit. Hoje, entretanto, o setor encontra-se em recuperação, depois de adotar medidas que deram início a um processo de reestruturação, com a modernização de seu parque de máquinas, aumento de produtividade e novas técnicas de gestão.

A participação do Brasil no comércio mundial é, ainda, de pouco menos de $1 \%$. Os países asiáticos, nossos maiores concorrentes, modernizaram-se rapidamente e, atualmente, aparecem, junto com os Estados Unidos, entre os maiores produtores e exportadores de têxteis (FRANCISCHINI e AZEVEDO, 2009).

O papel da indústria têxtil ao longo do processo de industrialização do Brasil, sempre foi importante geradora de emprego e renda, mesmo quando as outras indústrias encontraram dificuldades maiores e tiveram crescimento negativo, provavelmente por ser o produto têxtil pouco sensível à queda de renda da população, ou seja, de baixa renda.

A indústria têxtil do Brasil nasceu ainda no período colonial, desenvolveu-se acentuadamente a partir do início do século XX e encontrou a maturidade na década de 1940, quando chegou a ser considerada um setor industrial dinâmico de uma economia subdesenvolvida. Isto se verificou tendo em vista ter alcançado uma sólida estrutura que lhe conferiu a posição de segundo lugar na produção têxtil mundial, e de exportar para grande parte do mundo, por ocasião da Segunda Guerra Mundial (GORINI e SIQUEIRA, 2002).

O ramo têxtil, no Brasil, reestruturou-se progressivamente, definindo uma ruptura com os padrões vigentes até então, com amplos reflexos sobre os estabelecimentos e o emprego. No mesmo sentido, a balança comercial efetivou essa influência na evolução do ramo têxtil.

Algumas ações realizadas pelo governo, além daquelas adotadas pelas próprias indústrias, já contribuíram com a melhoria da balança comercial do setor. O BNDES criou, em 1996, um programa exclusivo para financiamento às indústrias têxteis, respeitando suas características (FRANCISCHINI e AZEVEDO, 2009).

A indústria têxtil caracteriza-se pela descontinuidade entre os segmentos. $O$ produto final de uma etapa constitui-se na matéria-prima para a seguinte. Apesar de constituírem etapas, na maioria das vezes sequenciais, cada um dos segmentos possui dinâmica própria, com especificidades tecnológicas de mercado e de matériaprima, existindo empresas que se dedicam exclusivamente a uma delas. 
No macrocomplexo têxtil, tanto a cadeia têxtil e de vestuário quanto a de calçados apresentaram queda de produção, apesar de suas importações terem apresentado as maiores quedas observadas no período. Esse comportamento foi claramente distinto no período quando as importações cresceram de forma explosiva (HAGUENAUER et al., 2001).

A cadeia produtiva têxtil vem passando por muitas transformações recentes, destacando-se especialmente aquelas relacionadas não apenas com as mudanças tecnológicas que permitiram expressivos incrementos de produtividade, mas também com a crescente importância do comércio intrabloco.

Além dos investimentos em novas tecnologias, a integração de empresas voltadas para fases distintas do processo têxtil apareceu como um fato relevante para a concretização de um novo padrão de concorrência. A histórica fragmentação do setor foi atenuada pela formação de redes compostas por ateliês de design, fornecedores de fibras e outras matérias-primas, tecelagens, confecções e grandes cadeias varejistas, em que a logística de toda a cadeia foi otimizada via informatização (GORINI, 2000).

A balança comercial do setor têxtil brasileiro sofreu duro impacto com a abertura comercial e, se antes apresentava saldo positivo, embora decrescente, passou a ter déficit.

De acordo com o IEMI (2014), entre 2010 e 2014, as importações nacionais de produtos têxteis não confeccionados cresceram 9,5\%, embora tivesse seu auge em 2011 e desacelerado a partir de então, conforme mostra o gráfico da figura 1.

As Importações brasileiras do segmento têxtil, respondem por $26 \%$ do consumo interno, vindas notadamente da China, Indonésia e Índia conforme mostrado no gráfico da figura 2, sendo que a maior parte desse volume são de fios e tecidos (figura $3)$. 
Figura 1 - Importações nacionais de têxteis (em US\$ milhões)

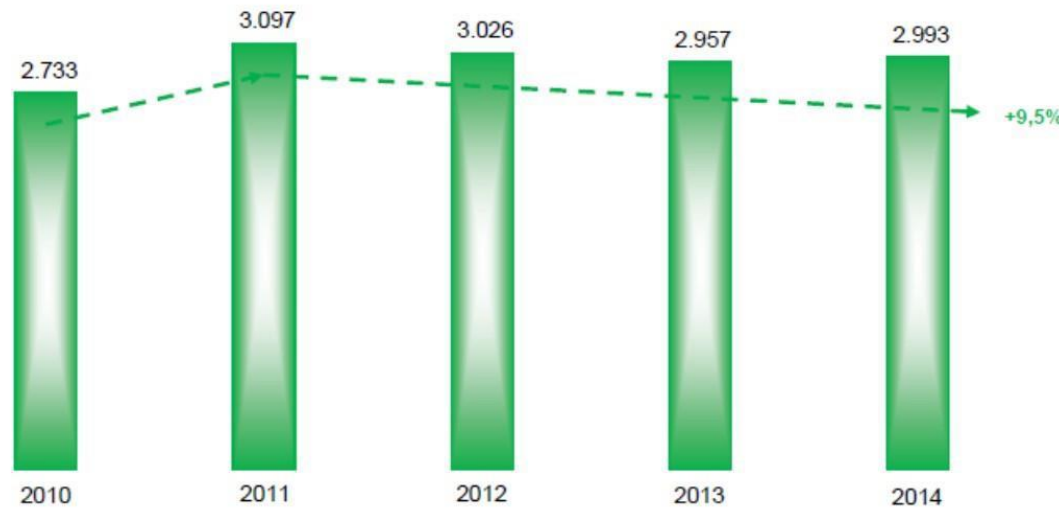

Fonte: IEMI, 2014

Figura 2 - Origem das importações nacionais de têxteis

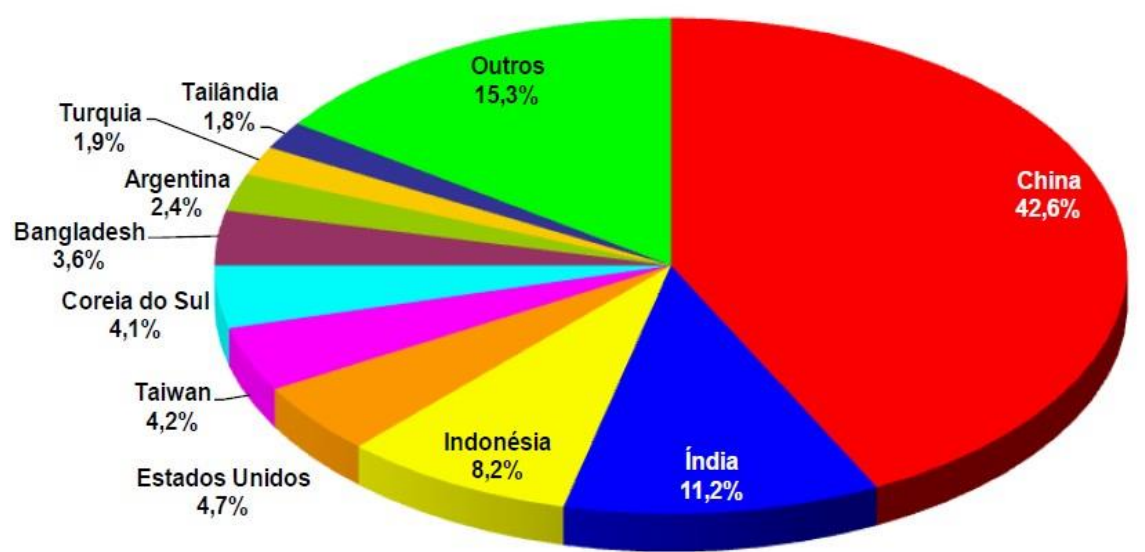

Fonte: IEMI, 2014

Figura 3 - Importações nacionais de têxteis por tipo de material

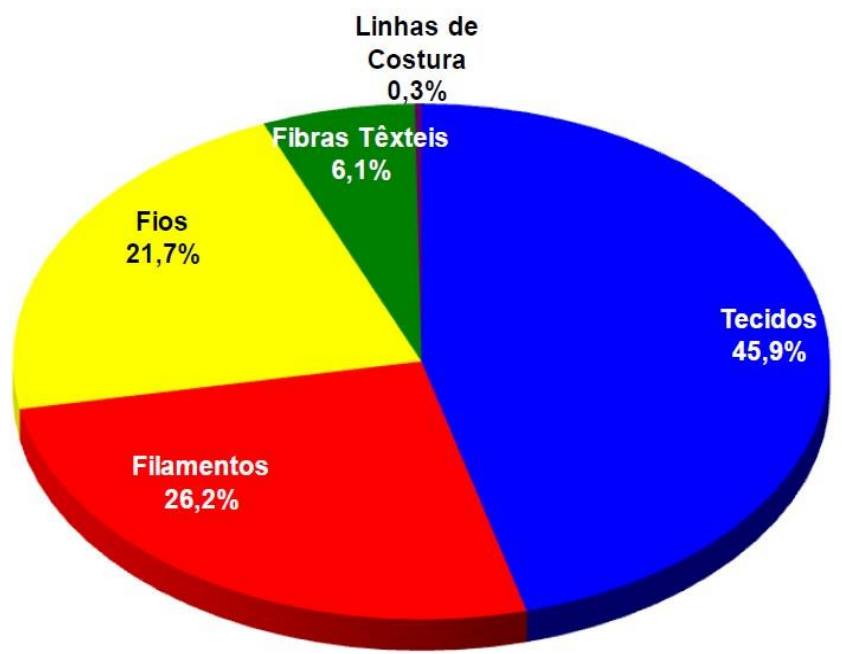

Fonte: IEMI, 2014 
Já a importação de confeccionados aumentou 127,5\% no mesmo período (2010 a 2014), conforme pode ser visto no gráfico da figura 4 .

No segmento de confeccionados, as importações respondem por $6,4 \%$ do mercado interno, sendo originadas notadamente da China (figura 5), sendo que o setor de vestuário responde por $74,5 \%$ do total (figura 6 ).

Figura 4 - Importações nacionais de confeccionados (em US\$ milhões)

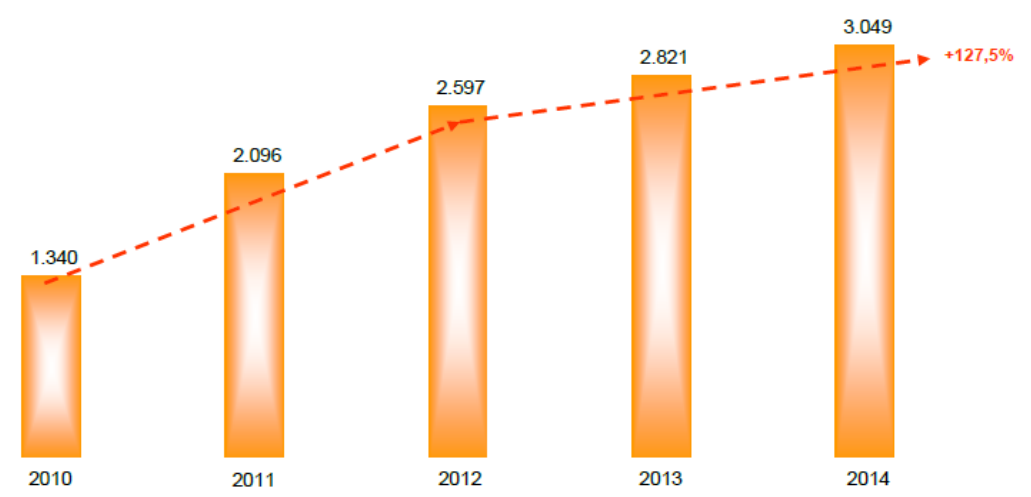

Fonte: IEMI, 2014

Figura 5 - Origem das importações nacionais de confeccionados

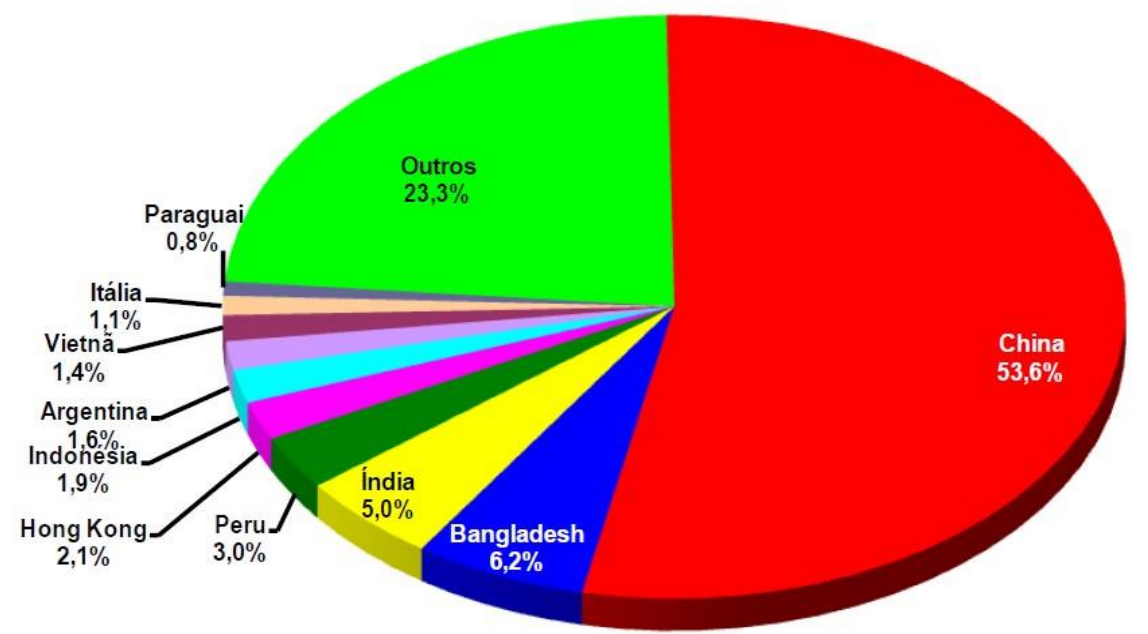

Fonte: IEMI, 2014 
Figura 6 - Importações nacionais de confeccionados por tipo de produto

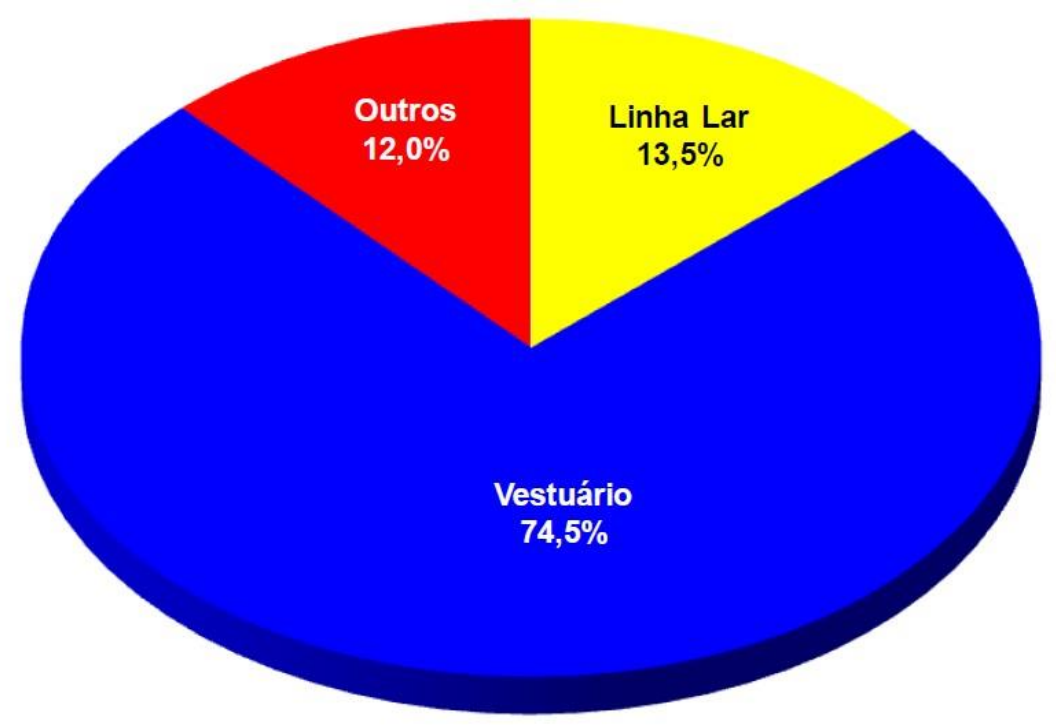

Fonte: IEMI, 2014

Hoje, entretanto, o setor busca uma recuperação, depois de adotar medidas que deram início a um processo de reestruturação, com a modernização de seu parque de máquinas, aumento de produtividade e novas técnicas de gestão.

O processo de liberalização comercial e de globalização dos mercados, desencadeado a partir da abertura comercial no Brasil durante a década de 1990, provocou uma reorganização do setor têxtil brasileiro, quando este buscou se adequar ao novo cenário econômico. A reorganização foi marcada por um conjunto de mudanças produtivas e institucionais que tanto destruiu diversas empresas e inúmeros postos de trabalho, quanto provocou uma reordenação deste setor produtivo, com a introdução de diversas inovações. De qualquer forma o setor passou a conviver com um nível de importações de produtos jamais visto em outras épocas e uma parcela dessas importações deve se tornar permanente.

\subsection{JUSTIFICATIVA}

Classificar uma mercadoria é o procedimento de maior complexidade de interpretação nos processos de comércio exterior, principalmente na importação. É a classificação fiscal que vai determinar se o bem a ser importado ou exportado tem necessidade de autorização/licença prévia ao embarque, os impostos incidentes e se há alguma medida específica em vigor, como antidumping por exemplo. 
A Classificação Fiscal de Mercadorias na NCM, por sua importância, está entre as principais dificuldades do dia a dia das empresas uma vez que é fundamental na determinação do IPI, na apuração dos tributos envolvidos nas operações de importação e exportação, bem como no montante do PIS/PASEP, da COFINS e do ICMS.

Efetuar a classificação correta da mercadoria é um trabalho extenso e, certamente, o mais importante de todo o processo de comércio exterior e, caso não seja efetuado corretamente, pode acarretar percalços que vão desde atrasos até a multas, sem falar no retrabalho gerado e que poderia ser evitado. Em casos de importação principalmente, deve-se dobrar a atenção ao solicitar que o fornecedor estrangeiro informe a classificação determinada pelo importador brasileiro, respeitando a estrutura da NCM, de modo que não haja dúvida no ato do desembaraço e tampouco erro de classificação que pode levar a multa por informação inexata.

Cabe a quem que está classificando o bem ler as notas de seção e capítulos presentes na Tarife Externa Comum (TEC - NCM), de modo a saber detalhadamente o que se enquadra e o que não se enquadra em determinada posição. As Notas Explicativas do Sistema Harmonizado (NESH) podem ajudar no entendimento das posições.

\subsection{OBJETIVO}

O objetivo desse trabalho é analisar a classificação de materiais têxteis na Nomenclatura Comum do Mercosul e desenvolver uma metodologia lógica que possibilite e facilite a sua correta classificação.

\subsection{METODOLOGIA}

Serão explorados os conceitos contidos na NESH e sua lógica de entendimento. Através do estudo de casos serão expostos exemplos de classificação especialmente escolhidos de forma a expor o raciocínio seguido nesses procedimentos.

\subsection{ORGANIZAÇÃO DO TRABALHO}

O trabalho será dividido em seis capítulos a saber: 
Capítulo 1 - Introdução: Apresenta um apanhado básico do que será tratado no trabalho, com objetivos, justificativa, perguntas e hipóteses e tipo de metodologia a ser utilizada, além do plano de organização do trabalho.

Capítulo 2 - Revisão bibliográfica: Esse capítulo tratará a evolução dos sistemas de classificação de mercadorias desde o seu surgimento até os dias atuais. Será discutida a sua evolução tanto no mundo como particularmente no Brasil. Também serão apresentados os sistemas atualmente vigentes no mundo (Sistema Harmonizado) e no Brasil (Nomenclatura Comum do Mercosul) com suas seções e capítulos, além de suas regras de interpretação e procedimentos classificatórios.

Também serão abordados detalhes da seção XI da NCM, Materiais têxteis e suas obras, avaliando seus capítulos principais, suas nuances, especificidades e descrição de materiais.

Capítulo 3 - Materiais e métodos: nesse capitulo serão desenvolvidos os conceitos básicos da lógica de classificação baseada na análise dos pontos chaves da NESH.

Capitulo 4 - Resultados e discussões: nesse capítulo serão apresentados alguns exemplos de classificação baseados nos conceitos desenvolvidos no capítulo 4

Capitulo 5 - Conclusão: serão apresentadas as conclusões obtidas no trabalho. 


\section{REVISÃO BIBLIOGRÁFICA}

\subsection{A CLASSIFICAÇÂO FISCAL DE MERCADORIAS}

Segundo Brogini (2008), no comercio internacional, "nomenclatura" é um tipo de codificação criada pelo homem para a identificação e classificação de mercadorias. Essa linguagem foi criada para facilitar o processo de troca comercial entre as nações, independentemente de diferenças linguísticas ou culturais. Com o aumento do comércio entre as nações tornou-se imperativo desenvolver métodos para identificação e classificação dos produtos visando determinar os tributos envolvidos nas operações de importação e exportação bem como o controle estatístico dessas operações.

Para facilitar as operações do comércio internacional, os países firmaram, ao longo do tempo, tratados que visavam padronizar a classificação dos produtos. $O$ principal deles é a Convenção Internacional sobre o Sistema Harmonizado de Designação e Codificação de Mercadorias, mais conhecida pela sigla SH (Sistema Harmonizado). Nesse sistema, as mercadorias são classificadas em códigos numéricos de seis dígitos, divididos em capítulos, seções e posições (BROGINI, 2008).

\subsection{HISTÓRICO}

A ideia da necessidade de uma nomenclatura uniforme que poderia ser a base para as tarifas aduaneiras de todos os países e que usaria uma única língua no comércio internacional, não se remonta a mais de um século.

Esta velha ambição de governos, empresas, especialistas aduaneiros e todos os interessados em comércio internacional, foi debatida em longos anos de estudos aprofundados e gerou enormes esforços para simplificar a harmonização dos procedimentos, e tornar possível a comparação dos direitos aduaneiros em benefício não só da sua aplicação segura, mas também a quantificação adequada do comércio internacional. A base das recomendações destinadas a alcançar este ideal foi baseada no fato conhecido que a diversidade de nomenclaturas aduaneiras nacionais representa uma série de problemas e obstáculos que impedem qualquer tentativa de análise racional e comparativa dos direitos aduaneiros e informações estatísticas 
sobre o comércio exterior.

Segundo Bizelli (2006), ao longo do tempo realizaram-se inúmeras conferências e congressos no mundo visando estabelecer uma nomenclatura mundial harmonizada para as mercadorias.

Uma das primeiras foi a Nomenclatura Estatística Internacional aprovada na $2^{\underline{a}}$ Conferência Internacional sobre Estatística Comercial, realizada em Bruxelas em 1913. Posteriormente surgiu a Nomenclatura Aduaneira da Liga das Nações, em 1937, conhecida como Nomenclatura de Genebra.

Ao final da 2ª Guerra Mundial, entre 1948 e 1949 os países da União Aduaneira Europeia, elaboraram, através de um Grupo de Estudos, um novo projeto baseado na Nomenclatura de Genebra. Esse projeto foi aprovado e incorporado ao Convênio de Bruxelas no final de 1950 com a denominação de Nomenclatura para a Classificação das Mercadorias nas Tarifas Aduaneiras.

A relação inicial do projeto sofreu modificações em 1955 que estabeleceu uma nova versão da nomenclatura, conhecida originalmente como NAB - Nomenclatura Aduaneira de Bruxelas e que, a partir de 1974, passou a ser denominada NCCA - Nomenclatura do Conselho de Cooperação Aduaneira.

Paralelamente, a Liga das Nações publicou, em 1938, uma "Lista Mínima de Mercadorias para Estatística de Comércio Exterior", baseada na Nomenclatura de Genebra. Entre 1948 e 1950, essa lista foi adotada e posteriormente modificada pela Comissão de Estatística das Nações Unidas.

Em 1950 o Conselho Econômico e Social das Nações Unidas adotou oficialmente essa classificação com o objetivo de facilitar o estudo e análise estatística dos fluxos do comércio internacional a qual passou a denominar-se CUCI Classificação Uniforme para o Comércio Internacional.

As estruturas da NCCA e da CUCl embora tivessem um vínculo estreito, não apresentavam nenhuma correlação direta. A NCCA tinha como objetivo principal discriminar mercadorias para fins aduaneiros enquanto que a CUCI visava a obtenção de informações para análises e comparações estatísticas.

Em 1970, a ONU e o Conselho de Cooperação Aduaneira (CCA), órgão da Organização Mundial de Aduanas (OMA), juntamente com outras entidades internacionais decidiram elaborar um estudo para a criação de uma nova nomenclatura comum que pudesse atender aos interesses aduaneiros e estatísticos dos países. Seu principal objetivo foi a criação de um sistema único mundial de 
designação e de codificação de mercadorias, podendo ser utilizado na elaboração das tarifas de direitos aduaneiros e de frete, nas estatísticas do comércio de importação e de exportação, de produção e dos diferentes meios de transporte de mercadorias, entre outras aplicações.

Após 13 anos, em junho de 1983, o CCA encerrou os trabalhos e aprovou o projeto de Convenção Internacional do Comitê sobre o Sistema Harmonizado de Designação e Codificação de Mercadorias, e sendo conhecida como a Nomenclatura do Sistema Harmonizado (SH). Atualmente mais de 170 países adotam a nomenclatura SH. No Brasil sua adoção foi promulgada pelo poder executivo por meio do decreto nํ9 97409 de 23 de dezembro de 1988.

\subsection{O SISTEMA HARMONIZADO (SH)}

O "Sistema Harmonizado de Designação e de Codificação de Mercadorias", ou simplesmente "Sistema Harmonizado" é um sistema único mundial que visa designar e codificar mercadorias, podendo ser utilizado na elaboração das tarifas de direitos aduaneiros e de frete, das estatísticas do comércio de importação e de exportação, de produção e dos diferentes meios de transporte de mercadorias, entre outras aplicações (BIZELLI, 2006).

O Sistema Harmonizado, tem a seguinte estrutura (figura 7):

- Nomenclatura - Compreende 21 seções, composta por 97 capítulos, além das notas de seção e de capítulo. Os capítulos, por sua vez, são divididos em posições e subposições, atribuindo-se códigos numéricos a cada um dos desdobramentos citados. Enquanto o capítulo 77 foi reservado para uma eventual utilização futura no $\mathrm{SH}$, os capítulos 98 e 99 foram reservados para usos especiais pelas partes contratantes. O Brasil, por exemplo, utiliza o Capítulo 99 para registrar operações especiais na exportação.

- Regras Gerais para a Interpretação do Sistema Harmonizado - Estabelecem as regras gerais de classificação das mercadorias na Nomenclatura.

- Notas Explicativas do Sistema Harmonizado (NESH) - Fornecem esclarecimentos e interpretam o Sistema Harmonizado, estabelecendo, detalhadamente, o alcance e conteúdo da Nomenclatura. 
Figura 7 - Estrutura do Sistema Harmonizado

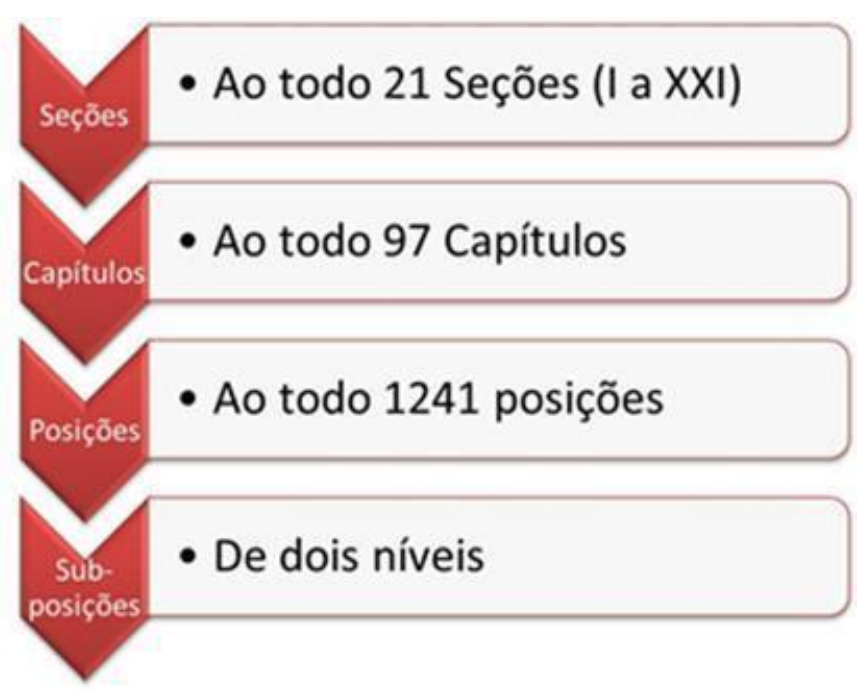

Fonte: Fabio Campos Fatalla, 2016

As mercadorias são identificadas por um conjunto de números, em ordem crescente, de acordo com o seu grau de elaboração, ou seja, quanto maior a complexidade do processo produtivo da mercadoria maior é seu número no Sistema Harmonizado. Dessa forma, as mercadorias estão ordenadas de forma progressiva, iniciando com animais vivos e terminando com as obras de arte, passando por matérias-primas e produtos semielaborados. Quanto maior a participação do homem na elaboração da mercadoria, mais elevado é o número do capítulo em que ela será classificada.

O SH compreende 5019 grupos ou categorias distintas de mercadorias identificadas por um código de 6 dígitos (DALSTON, 2006).

Conforme mostrado na figura 8 , os dois primeiros dígitos indicam o Capítulo. A Posição dentro do Capítulo é identificada pelos terceiro e quarto dígitos. O quinto dígito, denominado Subposição Simples (ou de 1ํㅡível), representa o desdobramento da Posição. O sexto dígito, Subposição Composta (ou de $2^{\circ}$ nível), corresponde ao desdobramento da Subposição Simples. Se o quinto e sexto dígitos forem iguais a zero, significa que não há desdobramento da Posição. Se somente o sexto dígito for igual a zero, significa que não há desdobramento da Subposição Simples em um $2^{\circ}$ nível. 


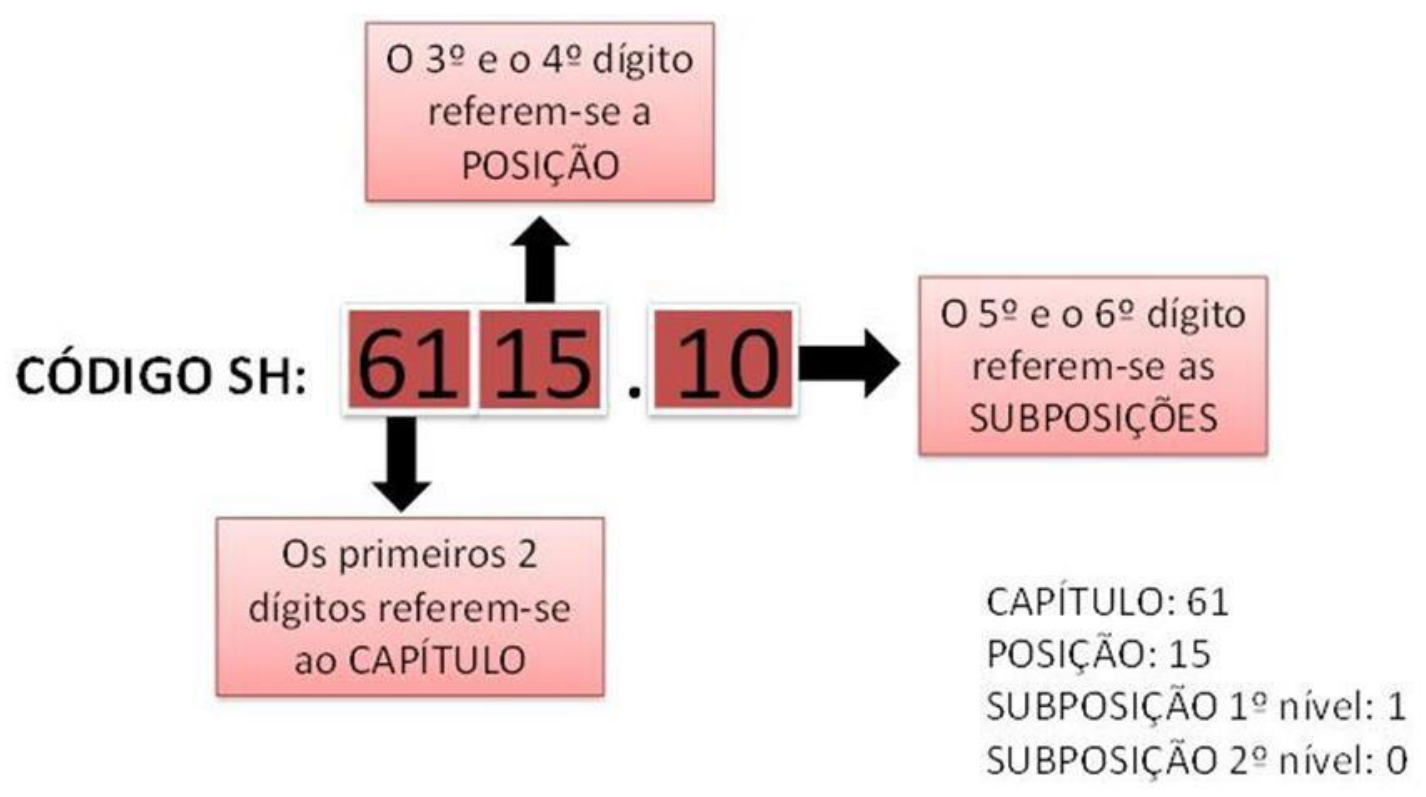

Fonte: Fabio Campos Fatalla, 2016

O decreto 1343/94 instituiu a TEC (Tarifa Externa Comum), que é formada pela NCM (Nomenclatura Comum do Mercosul) e as alíquotas de imposto de importação. Em 2001, a NCM e a TEC deixaram o âmbito do Ministério da Fazenda e passaram a ser responsabilidade da CAMEX (Câmara do Comércio Exterior) e do MDIC (Ministério do Desenvolvimento da Indústria e do Comércio).

\subsection{NOMENCLATURA COMUM DO MERCOSUL (NCM)}

A Nomenclatura SH é desdobrada pelas Nações, Uniões Econômicas e Uniões Aduaneiras de tal forma, que sejam obtidas as Nomenclaturas Nacionais ou Regionais. No âmbito do Mercosul, o SH foi desdobrado em Itens e Subitens (figura 9), formando a NCM, que é a Nomenclatura Comum do Mercosul adotada pelo Brasil e os demais países membros desde 1995 (SIFUENTES, 2013). 
Figura 9 - Estrutura da NCM

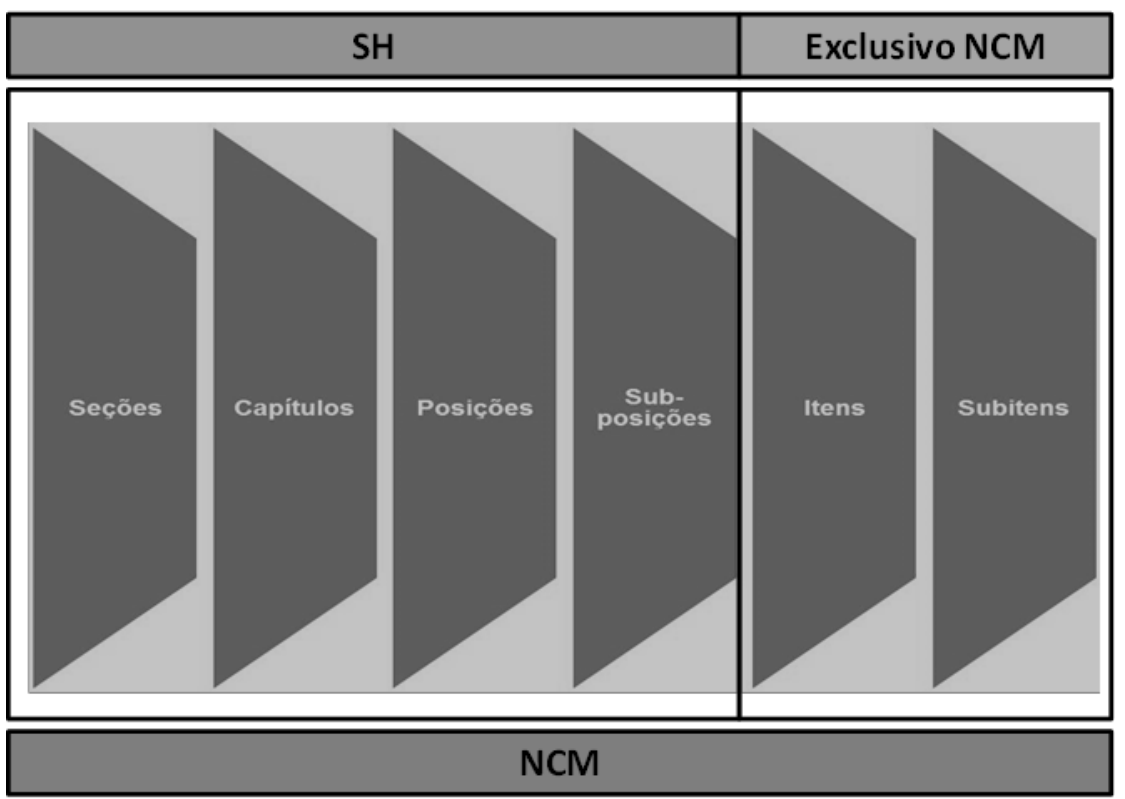

Fonte: Fabio Campos Fatalla, 2016

Além dos seis dígitos do Sistema Harmonizado, a NCM acrescentou mais dois dígitos, para os itens e subitens (figura 10). $\mathrm{O}$ item é representado pelo sétimo dígito e o subitem pelo oitavo dígito. Tanto itens quanto subitens desdobram-se de 0 a 9 . Um dígito zero em qualquer posição indica a ausência de desdobramentos.

Figura 10 - Organização da NCM

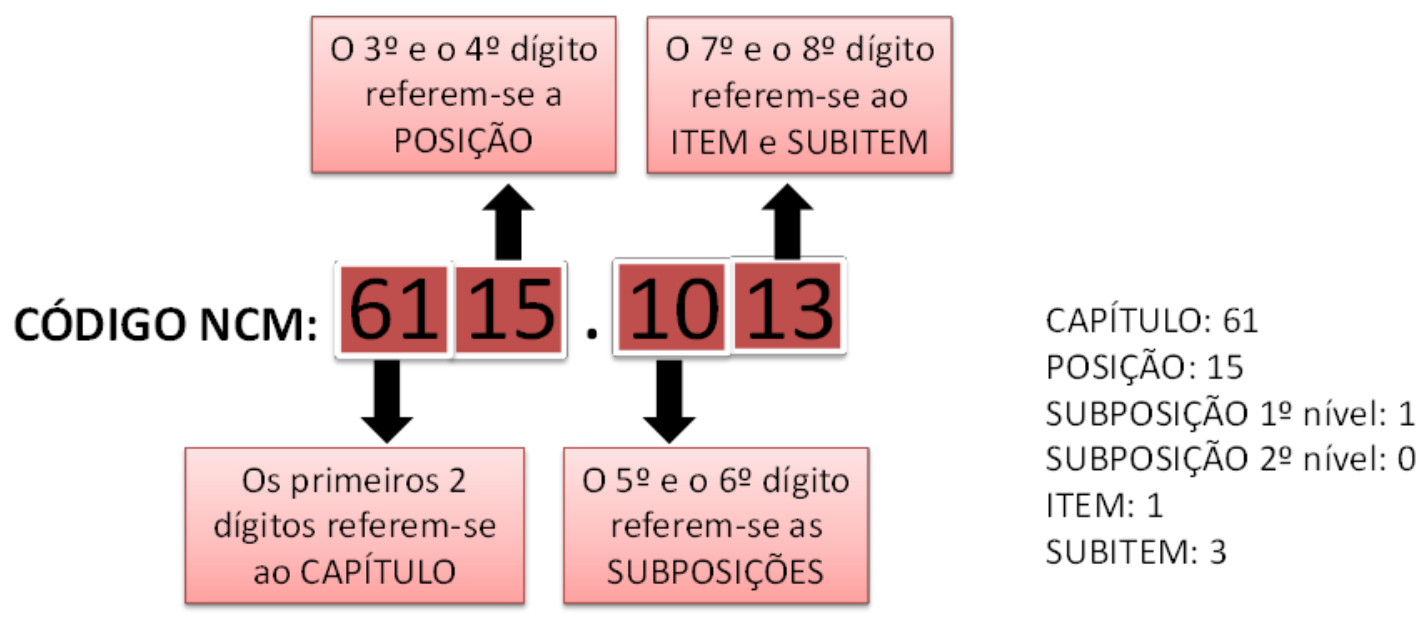

Fonte: Fabio Campos Fatalla, 2016 


\subsection{REGRAS DE INTERPRETAÇÃO}

A classificação de mercadorias deve ser feita mediante observação de algumas regras gerais e específicas (DALSTON, 2005).

As Regras Gerais do Sistema Harmonizado, contemplam as seis regras de interpretação, que devem ser aplicadas na ordem sequencial das mesmas. Além disso, existem no Mercosul duas Regras Gerais Complementares.

Entre as Normas específicas que regem a classificação de mercadorias incluem-se as Notas de seção, Notas de capítulos, Notas de Subposição, as Notas Explicativas do Sistema Harmonizado (NESH) além de Atos Declaratórios Interpretativos e Executivos e Instruções Normativas.

\subsubsection{Regras Gerais do sistema harmonizado}

De acordo com o Sistema Harmonizado, a classificação das mercadorias na sua Nomenclatura rege-se pelas seis regras seguintes, as quais devem ser aplicadas hierarquicamente em ordem sequencial.

\subsubsection{Regra 1}

Os títulos das Seções, Capítulos e Subcapítulos têm apenas valor indicativo. Para os efeitos legais, a classificação é determinada pelos textos das posições e das Notas de Seção e de Capítulo e pelas Regras seguintes desde que não sejam contrárias aos textos das referidas posições e Notas.

\subsubsection{Regra 2}

A regra 2 divide-se em duas partes a e b:

a) qualquer referência a um artigo em determinada posição abrange esse artigo mesmo incompleto ou inacabado, desde que apresente, no estado em que se encontra, as características essenciais do artigo completo ou acabado. Abrange igualmente o artigo completo ou acabado, ou como tal considerado nos termos das disposições precedentes, mesmo que se apresente desmontado ou por montar.

b) qualquer referência a uma matéria em determinada posição diz respeito a essa matéria, quer em estado puro, quer misturada ou associada a outras matérias. Da mesma forma, qualquer referência a obras de uma matéria determinada abrange 
as obras constituídas inteira ou parcialmente por essa matéria.

A classificação destes produtos misturados ou artigos compostos efetua-se conforme os princípios enunciados na Regra 3.

\subsubsection{Regra 3}

Quando parecer que a mercadoria pode classificar-se em duas ou mais posições por aplicação da Regra 2b ou por qualquer outra razão, a classificação deve efetuar-se da forma seguinte:

a) A posição mais específica prevalece sobre as mais genéricas. Todavia, quando duas ou mais posições se refiram, cada uma delas, a apenas uma parte das matérias constitutivas de um produto misturado ou de um artigo composto, ou a apenas um dos componentes de sortidos acondicionados para venda a retalho, tais posições devem considerar-se, em relação a esses produtos ou artigos, como igualmente específicas, ainda que uma delas apresente uma descrição mais precisa ou completa da mercadoria.

b) os produtos misturados, as obras compostas de matérias diferentes ou constituídas pela reunião de artigos diferentes e as mercadorias apresentadas em sortidos acondicionados para venda a retalho, cuja classificação não se possa efetuar pela aplicação da Regra 3a, classificam-se pela matéria ou artigo que Ihes confira a característica essencial, quando for possível realizar esta determinação.

c) nos casos em que as Regras 3a e 3b não permitam efetuar a classificação, a mercadoria classifica-se na posição situada em último lugar na ordem numérica, dentre as suscetíveis de validamente se tomarem em consideração.

\subsubsection{Regra 4}

As mercadorias que não possam ser classificadas por aplicação das Regras acima enunciadas classificam-se na posição correspondente aos artigos mais semelhantes.

\subsubsection{Regra 5}

Além das disposições precedentes, as mercadorias abaixo mencionadas estão sujeitas às regras seguintes: 
a) os estojos para aparelhos fotográficos, para instrumentos musicais, para armas, para instrumentos de desenho, para joias e receptáculos semelhantes, especialmente fabricados para conterem um artigo determinado ou um sortido, e suscetíveis de um uso prolongado, quando apresentados com os artigos a que se destinam, classificam-se com estes últimos, desde que sejam do tipo normalmente vendido com tais artigos. Esta Regra, todavia, não diz respeito aos receptáculos que confiram ao conjunto a sua característica essencial.

b) sem prejuízo do disposto na Regra 5a, as embalagens contendo mercadorias classificam-se com estas últimas quando sejam do tipo normalmente utilizado para o seu acondicionamento. Todavia, esta disposição não é obrigatória quando as embalagens sejam claramente suscetíveis de utilização repetida.

\subsubsection{Regra 6}

A classificação de mercadorias nas subposições de uma mesma posição é determinada, para efeitos legais, pelos textos dessas subposições e das Notas de Subposição respectivas, assim como, mutatis mutandis, pelas Regras precedentes, entendendo-se que apenas são comparáveis subposições do mesmo nível. Para os fins da presente Regra, as Notas de Seção e de Capítulo são também aplicáveis, salvo disposições em contrário.

\subsubsection{Regras Gerais Complementares (RGC)}

O sistema de classificação considera ainda algumas regras gerais complementares conforme disposto a seguir:

\subsubsection{Regra geral complementar 1}

As Regras Gerais para Interpretação do Sistema Harmonizado se aplicarão, "mutatis mutandis", para determinar dentro de cada posição ou sub posição, o item aplicável e, dentro deste último, o subitem correspondente, entendendo-se que apenas são comparáveis desdobramentos regionais (itens e subitens) do mesmo nível. 


\subsubsection{Regra geral complementar 2}

As embalagens contendo mercadorias e que sejam claramente suscetíveis de utilização repetida, mencionadas na Regra 5 b), seguirão seu próprio regime de classificação sempre que estejam submetidas aos regimes aduaneiros especiais de admissão temporária ou de exportação temporária. Caso contrário, seguirão o regime de classificação das mercadorias.

\subsubsection{Notas Explicativas do Sistema Harmonizado (NESH)}

Para permitir a correta identificação de um código da NCM, se faz necessário conhecer as notas explicativas do sistema harmonizado de designação e de codificação de mercadorias, mais conhecidas por NESH (OLIVEIRA, 2009)

As Notas Explicativas do Sistema Harmonizado de Codificação e Classificação de Mercadorias (NESH) compreendem as Notas de Seção, de Capítulo e de Subposição. Trata-se de material extenso e pormenorizado, que estabelece, detalhadamente, o alcance e conteúdo da Nomenclatura abrangida pelo Sistema Harmonizado, divulgado por Instruções Normativas da Receita Federal do Brasil.

\subsubsection{Consulta à Receita Federal}

É possível realizar uma consulta para interpretação de mercadorias na NCM à Secretaria da Receita Federal pela própria empresa interessada conforme Instrução Normativa da RFB no573/02. (CIESP, 2007)

A consulta deverá conter os seguintes elementos de informação sobre a mercadoria:

a) Nome vulgar, comercial, científico e técnico

b) Marca registrada, modelo, tipo e fabricante

c) Função principal e secundária

d) Princípio e descrição resumida do funcionamento

e) Aplicação, uso e emprego

f) Forma de acoplamento de motor a máquina ou aparelhos, quando for o caso

g) Dimensões e peso líquido

h) Peso molecular, ponto de fusão e densidade, para produtos do capítulo 
39 da NCM

i) Forma (líquido, pó, escamas, etc.) e apresentação (tambores, caixas, etc.)

j) Matéria ou matérias de que é constituída a mercadoria e suas percentagens em peso ou em volume

k) Processo de obtenção (industrial, farmacêutico, etc.), com descrição detalhadas

l) Classificação adotada e pretendida

\subsubsection{As seções da NCM}

A NCM é composta de vinte e uma seções que estão listadas a seguir:

- Seção I - Animais vivos e produtos do reino animal

- Seção II - Produtos do reino vegetal

- Seção III - Gorduras e óleos animais ou vegetais; produtos da sua dissociação; gorduras alimentares elaboradas; ceras de origem animal ou vegetal

- Seção IV - Produtos das indústrias alimentares; bebidas, líquidos alcoólicos e vinagres; tabaco e seus sucedâneos manufaturados

- Seção V - Produtos minerais

- Seção VI - Produtos das indústrias químicas ou das indústrias conexas

- Seção VII - Plásticos e suas obras; borracha e suas obras

- Seção VIII - Peles, couros, peles com pelo e obras destas matérias; artigos de correeiro ou de seleiro; artigos de viagem, bolsas e artefatos semelhantes; obras de tripa

- Seção IX - Madeira, carvão vegetal e obras de madeira; cortiça e suas obras; obras de espartaria ou de cestaria

- Seção X - Pastas de madeira ou de outras matérias fibrosas celulósicas; papel ou cartão para reciclar (desperdícios e aparas); papel ou cartão e suas obras

- Seção XI - Matérias têxteis e suas obras

- Seção XII - Calçados, chapéus e artefatos de uso semelhante, guardachuvas, guarda-sóis, bengalas, chicotes, e suas partes; penas preparadas e suas obras; flores artificiais; obras de cabelo

- Seção XIII - Obras de pedra, gesso, cimento, amianto, mica ou de 
matérias semelhantes; produtos cerâmicos; vidro e suas obras

- Seção XIV - Pérolas naturais ou cultivadas, pedras preciosas ou semipreciosas e semelhantes, metais preciosos, metais folheados ou chapeados de metais preciosos (plaquê), e suas obras; bijuterias; moedas

- Seção XV - Metais comuns e suas obras

- Seção XVI - Máquinas e aparelhos, material elétrico, e suas partes; aparelhos de gravação ou de reprodução de som, aparelhos de gravação ou de reprodução de imagens e de som em televisão, e suas partes e acessórios

- Seção XVII - Material de transporte

- Seção XVIII - Instrumentos e aparelhos de óptica, de fotografia, de cinematografia, de medida, de controle ou de precisão; instrumentos e aparelhos médico-cirúrgicos; artigos de relojoaria; instrumentos musicais; suas partes e acessórios

- Seção XIX - Armas e munições; suas partes e acessórios

- Seção XX - Mercadorias e produtos diversos

- Seção XXI - Objetos de arte, de coleção e antiguidades

\subsection{A SEÇÃO XI DA NCM: MATERIAIS TÊXTEIS E SUAS OBRAS}

Os materiais têxteis em geral estão abordados na Seção XI - Materiais têxteis e suas obras, nos capítulos 50 a 63. Desta seção fazem parte:

- Matérias-primas da indústria têxtil (fibras)

-Produtos intermediários (fios, tecidos e malhas)

- Produtos confeccionados para vestuário, cama, mesa e banho

Na figura 11 estão descritos os Capítulos que compõem a Seção XI: 
Figura 11 - Capítulos da Seção XI

\begin{tabular}{|c|c|}
\hline 50 & SEDA \\
\hline 51 & LÃ, PELOS FINOS OU GROSSEIROS; FIOS E TECIDOS DE CRINA \\
\hline 52 & ALGODÃO \\
\hline 53 & OUTRAS FIBRAS TÊXTEIS VEGETAIS; FIOS DE PAPEL E TECIDOS DE FIOS DE PAPEL \\
\hline 54 & $\begin{array}{l}\text { FILAMENTOS SINTÉTICOS OU ARTIFICIAIS; LÂMINAS E FORMAS SEMELHANTES DE } \\
\text { MATÉRIAS TÊXTEIS SINTÉTICAS OU ARTIFICIAIS }\end{array}$ \\
\hline 55 & FIBRAS SINTÉTICAS OU ARTIFICIAIS, DESCONTÍNUAS \\
\hline 56 & $\begin{array}{l}\text { PASTAS (OUATES), FELTROS E FALSOS TECIDOS; FIOS ESPECIAIS; CORDÉIS, CORDAS } \\
\text { E CABOS; ARTIGOS DE CORDOARIA }\end{array}$ \\
\hline 57 & $\begin{array}{l}\text { TAPETES E OUTROS REVESTIMENTOS PARA PISOS (PAVIMENTOS), DE MATÉRIAS } \\
\text { TÊXTEIS }\end{array}$ \\
\hline 58 & $\begin{array}{l}\text { TECIDOS ESPECIAIS; TECIDOS TUFADOS; RENDAS; TAPEÇARIAS; PASSAMANARIAS; } \\
\text { BORDADOS }\end{array}$ \\
\hline 59 & $\begin{array}{l}\text { TECIDOS IMPREGNADOS, REVESTIDOS, RECOBERTOS OU ESTRATIFICADOS; } \\
\text { ARTIGOS PARA USOS TÉCNICOS DE MATÉRIAS TÊXTEIS }\end{array}$ \\
\hline 60 & TECIDOS DE MALHA \\
\hline 61 & VESTUÁRIO E SEUS ACESSÓRIOS, DE MALHA \\
\hline 62 & VESTUÁRIO E SEUS ACESSÓRIOS, EXCETO DE MALHA \\
\hline 63 & $\begin{array}{l}\text { OUTROS ARTEFATOS TÊXTEIS CONFECCIONADOS; SORTIDOS; ARTEFATOS DE } \\
\text { MATÉRIAS TÊXTEIS, CALÇADOS, CHAPÉUS E ARTEFATOS DE USO SEMELHANTE, } \\
\text { USADOS; TRAPOS }\end{array}$ \\
\hline
\end{tabular}

Fonte: Fabio Campos Fatalla com base na NESH, 2016

Essa seção tem foco sobretudo nos matérias têxteis intermediárias e artigos acabados para vestuário e têxteis do lar.

Algumas exceções a esse conceito são materiais de composição têxtil de uso técnico ou utilizados em máquinas, aparelhos, instalações ou instrumentos incluídos nos capítulos 56 e 59 tais como:

- Cabos e cordas

- Mechas para isqueiros, velas, etc.

- Correias transportadoras ou de transmissão

- Mangueiras e tubos

Se tomarmos como exemplo uma camisa, tanto o tecido utilizado na sua fabricação como a camisa em si são classificados na seção XI, porém em capítulos diferentes. Se uma empresa importa tecido a ser utilizado na produção de camisas este será classificado num capítulo. Se ao invés disso a empresa importa a camisa 
pronta esta será classificada em outro capítulo, mas ambos da Seção XI.

No entanto, outros produtos acabados ou confeccionados de outras áreas não estão incluídos nessa seção mesmo que sejam constituídos total ou parcialmente de têxteis. Vejamos alguns exemplos:

- Os tecidos usados na confecção de calçados pertencem à Seção XI, porém os calçados, independentemente de sua composição são classificados na seção XII Calçados, chapéus e artefatos de uso semelhante, guarda-chuvas, guarda-sóis, bengalas, chicotes, e suas partes; penas preparadas e suas obras; flores artificiais; obras de cabelo.

- O fio usado como matéria prima para produção de fio dental pertence à Seção $\mathrm{XI}$ enquanto que o fio dental pronto em embalagem para venda no varejo é classificado na Seção VI - Produtos das indústrias químicas ou das indústrias conexas

- O tecido e as fibras de enchimento que compõem uma almofada são classificados cada um em seu respectivo capítulo na Seção XI. No entanto a almofada pronta deve ser classificada na seção na Seção XX - Mercadorias e produtos diversos

- Os materiais têxteis usados na fabricação de roupas para bonecas são classificados individualmente na Seção XI. Já a roupa da boneca para venda bem como a própria boneca vestida com a roupa devem ser classificados na Seção XX Mercadorias e produtos diversos

- As telas para pneus são classificadas na Seção XI enquanto que o pneu acabado dever ser classificado na Seção VII - Plásticos e suas obras; borracha e suas obras.

Os Capítulos da Seção XI podem ser divididos em dois grupos que apresentam mecânicas de classificação distintas:

- Capítulos 50 a 55, que incluem fibras, fios e tecidos planos e cuja classificação é norteada inicialmente pelo tipo de fibra;

- Capítulos 56 a 63 que incluem os demais materiais têxteis da seção.

\subsection{CLASSIFICAÇÃO DOS TÊXTEIS NOS CAPÍTULOS 50 a 55}

Nesses Capítulos os produtos têxteis são agrupados conforme as matérias que os constituem (figura 12). Cada um deles trata de uma ou de várias matérias têxteis, puras ou misturadas entre si, nas diferentes fases de manufatura até a sua transformação em tecidos. 
Figura 12 - Capítulos 50 a 55

\begin{tabular}{|l|l|}
\hline $\mathbf{5 0}$ & SEDA \\
\hline $\mathbf{5 1}$ & LÃ, PELOS FINOS OU GROSSEIROS; FIOS E TECIDOS DE CRINA \\
\hline $\mathbf{5 2}$ & ALGODÃO \\
\hline $\mathbf{5 3}$ & OUTRAS FIBRAS TÊXTEIS VEGETAIS; FIOS DE PAPEL E TECIDOS DE FIOS DE PAPEL \\
\hline $\mathbf{5 4}$ & $\begin{array}{l}\text { FILAMENTOS SINTÉTICOS OU ARTIFICIAIS; LÂMINAS E FORMAS SEMELHANTES DE } \\
\text { MATÉRIAS TÊXTEIS SINTÉTICAS OU ARTIFICIAIS }\end{array}$ \\
\hline $\mathbf{5 5}$ & FIBRAS SINTÉTICAS OU ARTIFICIAIS, DESCONTÍNUAS \\
\hline
\end{tabular}

Fonte: Fabio Campos Fatalla com base na NESH, 2016

Eles compreendem gradativamente (figura 13):

- Matéria-prima (fibras)

- Desperdícios e resíduos de recuperação

- Fios

- Tecidos

Figura 13 - Capítulos 50 a 55
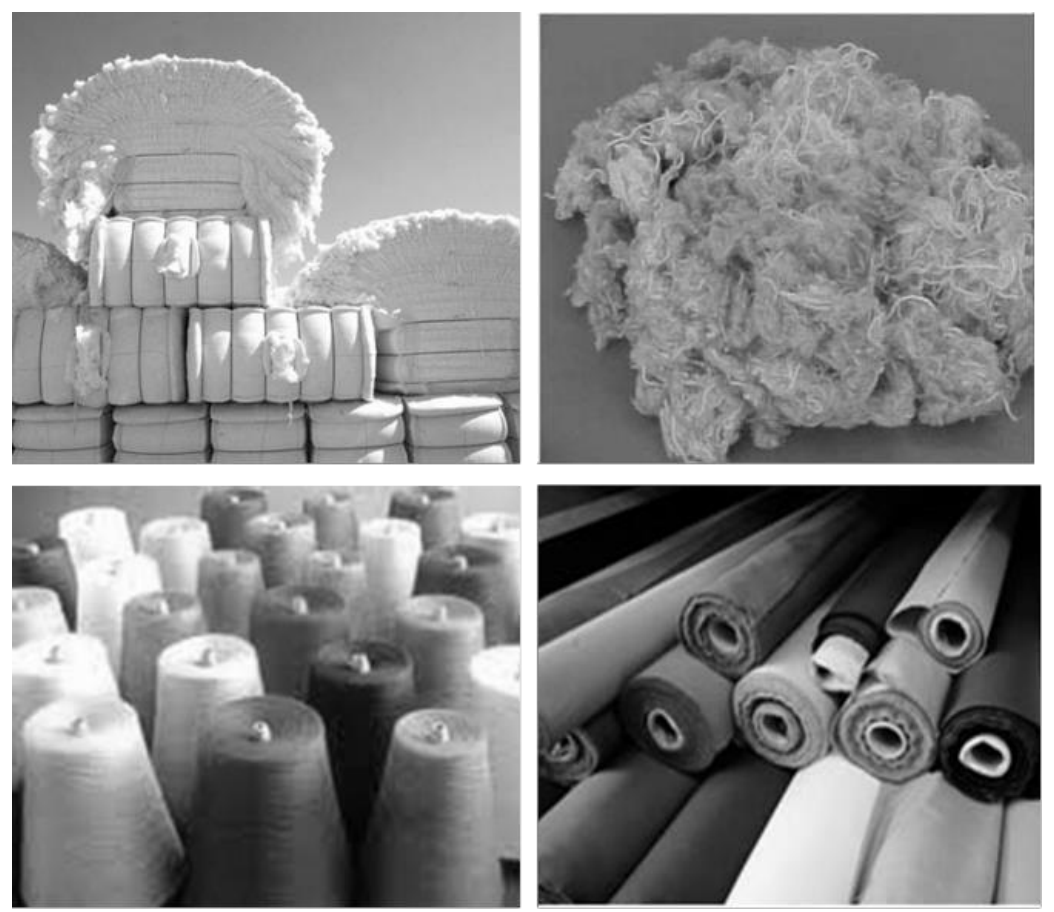

Fonte: Fabio Campos Fatalla a partir de imagens diversas, 2016 


\subsubsection{Fibras têxteis}

As principais matérias primas têxteis (fibras) estão mostradas no quadro da figura 14, de acordo com Maluf e Kolbe (2003).

Figura 14 - Principais fibras têxteis

\begin{tabular}{|c|c|c|c|c|c|}
\hline \multirow{8}{*}{$\begin{array}{l}\frac{n}{5} \\
\frac{\underline{s}}{2} \\
\frac{2}{2} \\
z\end{array}$} & & \multirow{3}{*}{ Vegetais } & de sementes & \multicolumn{2}{|l|}{ coco, algodão } \\
\hline & & & de caules & \multicolumn{2}{|c|}{ cânhamo, juta, linho, malva, rami, abacá } \\
\hline & & & de folhas & \multicolumn{2}{|c|}{ sisal, ráfia, abacaxi, bananeira, piaçava } \\
\hline & \multirow{4}{*}{\multicolumn{2}{|c|}{ Animais }} & 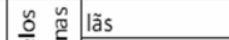 & \multicolumn{2}{|c|}{ ovelhas } \\
\hline & & & $\bar{\Xi} \bar{u}$ pelos finos & \multicolumn{2}{|c|}{ alpaca, angorá, cashemire, coelho, Ihama, vicunha, ca melo } \\
\hline & & & $\frac{8}{0}$ pelos grossos & \multicolumn{2}{|c|}{ cabras } \\
\hline & & & de secreção & \multicolumn{2}{|c|}{ seda cultivada e seda Tussah } \\
\hline & & Minerais & amianto ou asbesto & \multicolumn{2}{|l|}{ crisolita } \\
\hline \multirow{13}{*}{ 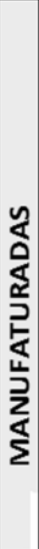 } & \multirow{5}{*}{\multicolumn{2}{|c|}{$\begin{array}{l}\text { Artificiais } \\
\text { (polimeros } \\
\text { naturais) }\end{array}$}} & \multirow{2}{*}{ celulósicas (vegetais) } & celulose regenerada & viscose, liocel, modal, polinósica \\
\hline & & & & éster de celulose & acetato, triacetato \\
\hline & & & de algas & \multicolumn{2}{|l|}{ alginato } \\
\hline & & & de látices & \multicolumn{2}{|l|}{ borracha } \\
\hline & & & de animais & \multicolumn{2}{|l|}{ caseina (leite) } \\
\hline & \multirow{7}{*}{ 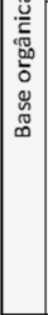 } & \multirow{7}{*}{\begin{tabular}{|l} 
\\
Sintéticas \\
(polimeros \\
sintéticos)
\end{tabular}} & \multirow{3}{*}{ por policondensação } & \multicolumn{2}{|l|}{ poliéster } \\
\hline & & & & \multirow{2}{*}{ poliamidas } & cadeia normal \\
\hline & & & & & cadeia aromática \\
\hline & & & \multirow{3}{*}{ por polimerização } & olefinas & polietileno, polipropileno, elastodieno \\
\hline & & & & \begin{tabular}{|l|} 
combinações \\
de polivinila
\end{tabular} & $\begin{array}{l}\text { acrilica, modacrílica, vinial, vinilal, poli } \\
\text { cloreto de vinila, poli cloreto de vinilideno }\end{array}$ \\
\hline & & & & de flúor & politetrafluo retileno, policlorotrifluoretileno \\
\hline & & & por poliadição & \multicolumn{2}{|l|}{ elastana, poliuretana } \\
\hline & \multicolumn{2}{|c|}{ Base inorgânica } & \multicolumn{3}{|c|}{$\begin{array}{l}\text { Carbono, cerâmica, lã de escória, } \\
\text { lã de rocha, metálica, vidro }\end{array}$} \\
\hline
\end{tabular}

Fonte: Maluf e Kolbe (2003)

De acordo com a ABNT (NBR 12744/1992) as fibras têxteis são classificadas conforme o quadro da figura $15 \mathrm{com}$ as respectivas siglas.

Figura 15 - Classificação e siglas das fibras têxteis segundo a ABNT

\begin{tabular}{|c|c|c|c|}
\hline FIBRAS NRT URQIS & FIBRQ S NATURAIS & FIBRAS ARTIFICIRIS & FIBRASS SINTETICAS \\
\hline VEGETRIS & ANIMAIS & & \\
\hline SEMENTES & SECREÇ:̈O & CA-Acetato & PAN-Acŕlica \\
\hline CO -AIgodầ & S. Seda & AL-Aginato & AR - Ararrida \\
\hline CP - Capoque (Paina) & PELOOS & LA- Borracha & PVC - Cloreto de polivirila \\
\hline CQULES & WP-Apaca & CAR- Carbono & PVD-Cloreto de polivirilideno \\
\hline CH-Cânhamo & WAA-Angorá & CPT-Caseina & EL- Bastano \\
\hline CJ.Juta & wc- Cabra & CUP-Cupro & MAC-Mbdacrílica \\
\hline CK - Kenaf & Wus - Cashmere & SLF - Esoória & PVH-Multipolímero \\
\hline $\mathrm{CL}$ - Linho & WiK-Camelo & CLY-Liocel & PA-Poliarrida* \\
\hline OM-Malne & WR-Coelho & MTF - Metálica & PUA-Policarbarrida \\
\hline CR - Rarri & WO- Lã & MT - Metaiz adas & PCF-Polidorotrifluoretileno \\
\hline FOLHAS & WL- Lharna & CMD - Moda & PES - Poliéster \\
\hline CB-Abacá & WM-Mohair & STF-Rocha & PST - Poliestireno \\
\hline CN - Canoá (Conoá) & WV-Mounha & CTA- Triacetato & PE - Polietileno \\
\hline CF-Fórmio & MINERA IS & GF - Vidro & PP - Polipropileno \\
\hline CS - Sisal & A- Asbesto (Arrianto) & CV-Uscose & PFT- Politetrafluoretileno \\
\hline FRUTOS & & & PUR - Poliunatana \\
\hline $\mathrm{CC} \cdot \mathrm{COON}$ & & & PVA- Mna \\
\hline
\end{tabular}


De acordo com Araujo e Castro (1986), dependendo do processo de obtenção podem ser obtidos diversos tipos de materiais:

- $\quad$ Fio monofilamento

- $\quad$ Fio multifilamento

- $\quad$ Filamento

- Fibra descontínua

- Flocos

- Fibras perfiladas

- $\quad$ Fibras bi componentes

- $\quad$ Filamentos cortados de filmes

- $\quad$ Filamentos ou fibras de fibrilação

A figura 16 mostra um resumo dessas possibilidades:

Figura 16 - Principais apresentações dos materiais têxteis

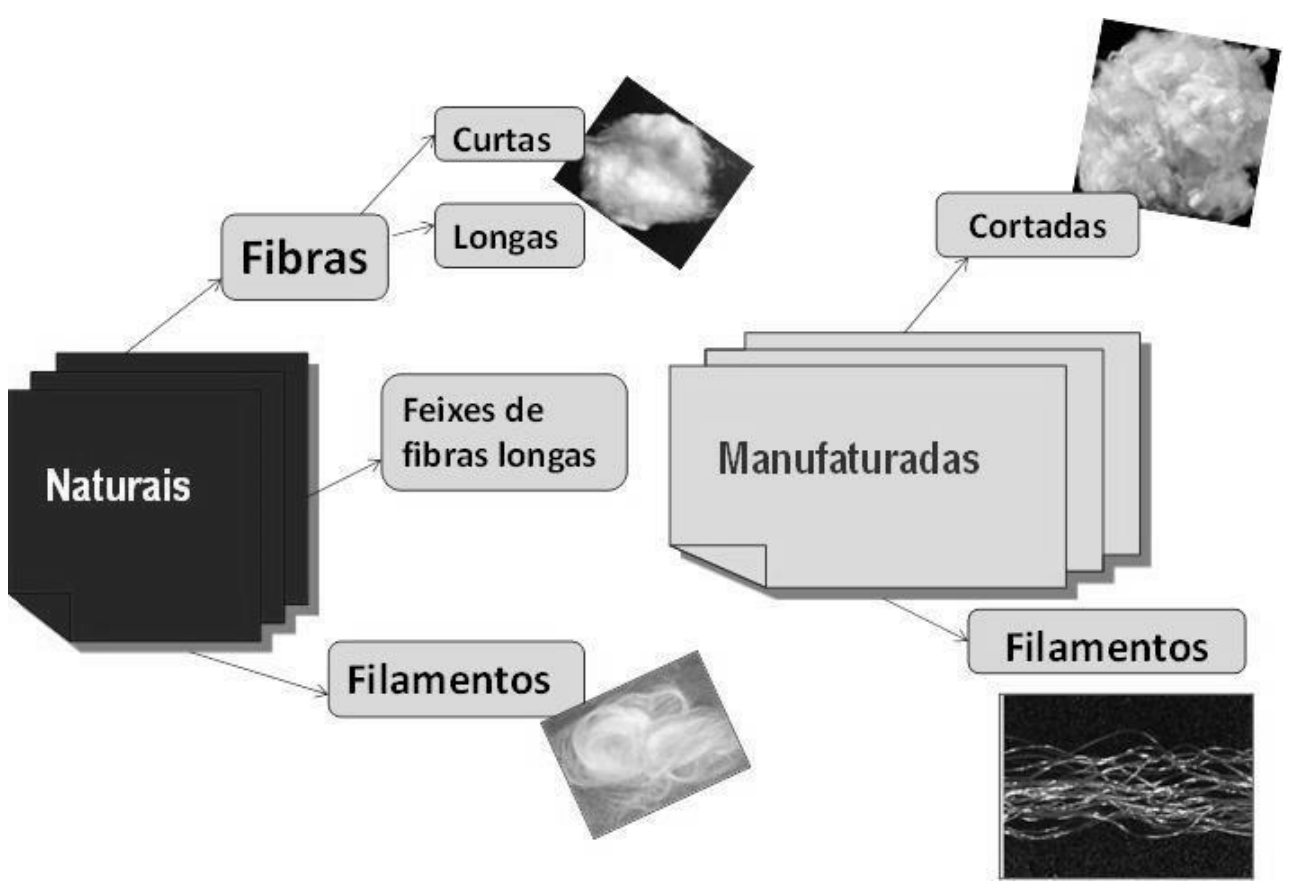

Fonte: Fabio Campos Fatalla, 2016

\subsubsection{Fibras naturais}

As fibras naturais são encontradas na natureza e subdividem-se em animais, 
vegetais e minerais (MALUF e KOLBE, 2003), conforme mostrado na figura 17.

Figura 17 - Fibras naturais

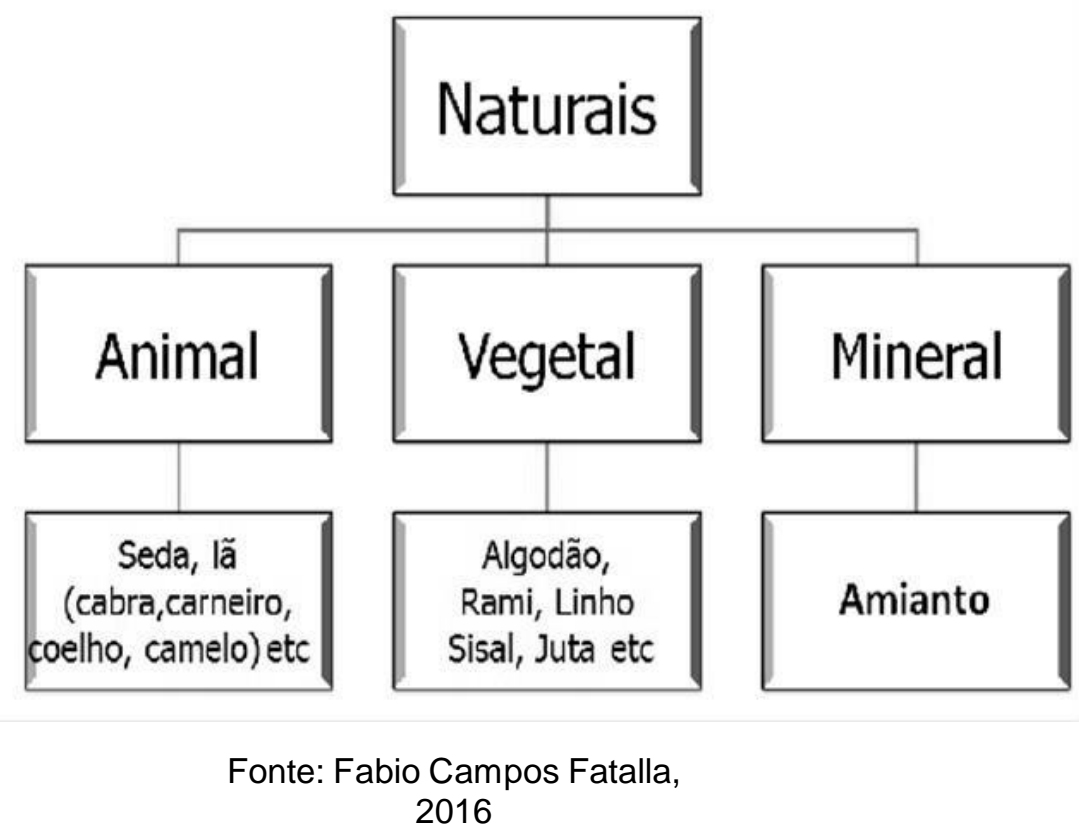

\subsubsection{Fibras químicas}

De acordo com Cook (1984), são fibras produzidas pelo homem partir de polímeros naturais (fibras artificiais) ou de polímeros produzidos também pelo homem (fibras sintéticas) conforme mostrado na figura 18.

Figura 18 - Fibras químicas

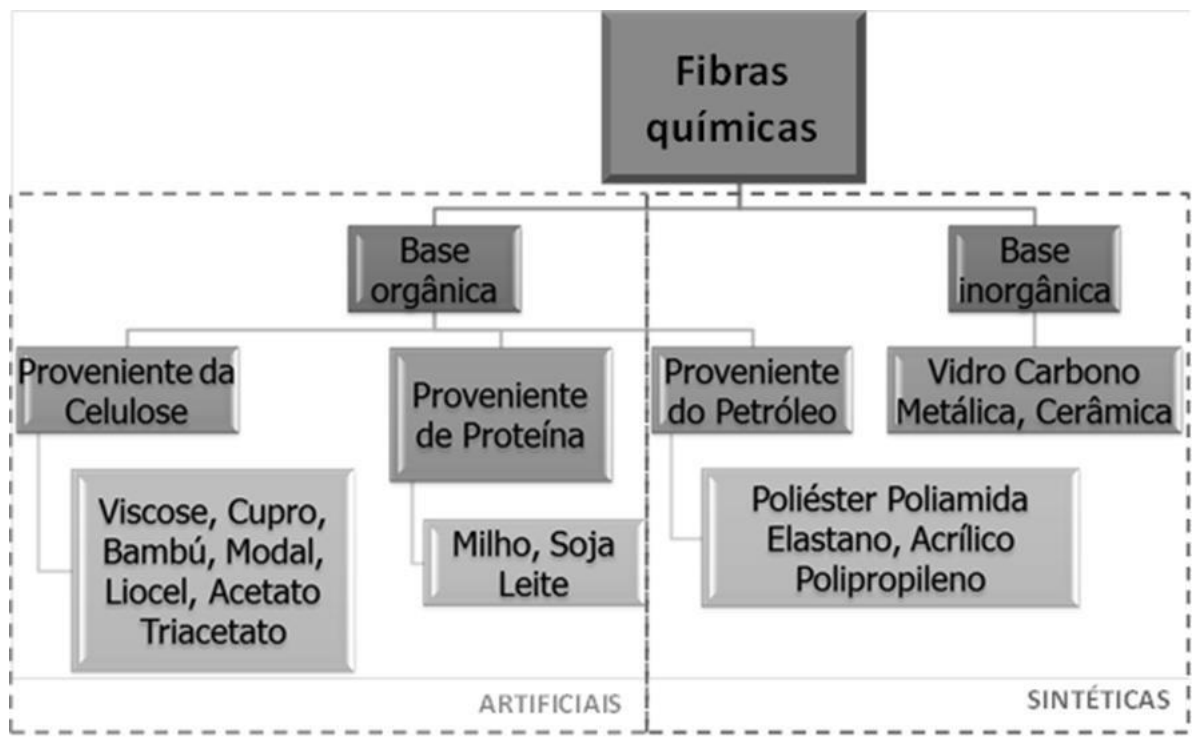

Fonte: Fabio Campos Fatalla, 2016 


\subsubsection{Construção dos fios}

Segundo Lord (2003), os fios têxteis podem ser construídos de diversas formas conforme resumido a seguir.

\subsubsection{Fios simples (singelos)}

São fios constituídos de apenas um cabo e podem ser obtidos por diferentes processos:

- Fios fiados: Constituídos por fibras descontínuas reunidas por torção ou outro método de coesão (figura 19).

Figura 19 - Fios singelos fiados

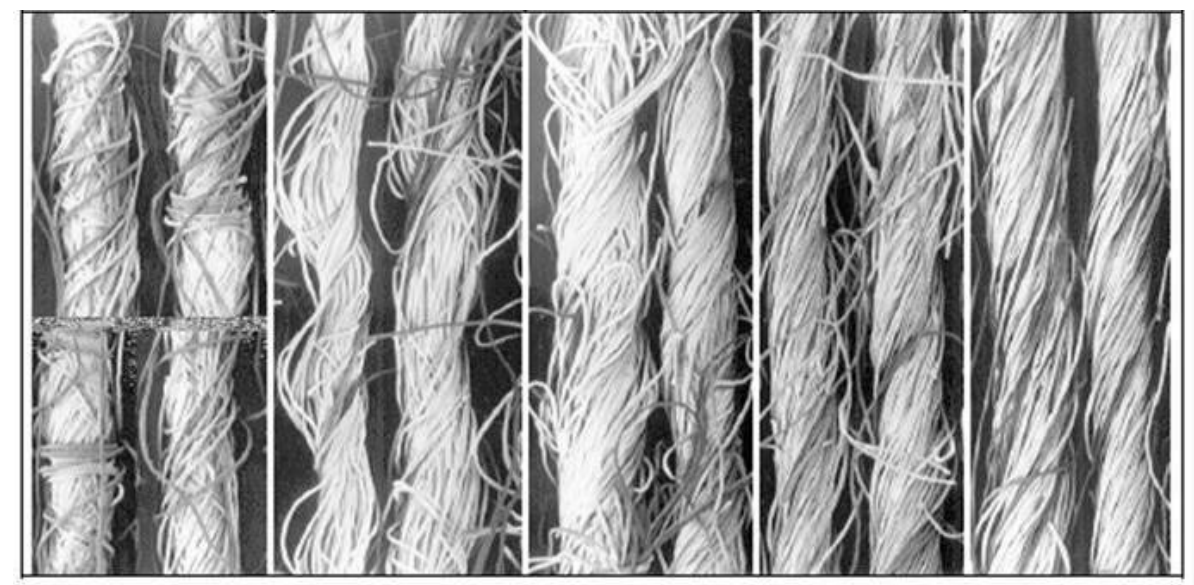

Fonte: Lord (2003)

- Fios monofilamentos (geralmente lisos): filamentos individuais contínuos obtidos na fiação de fibras químicas (figura 20).

Figura 20 - Fios singelos monofilamento
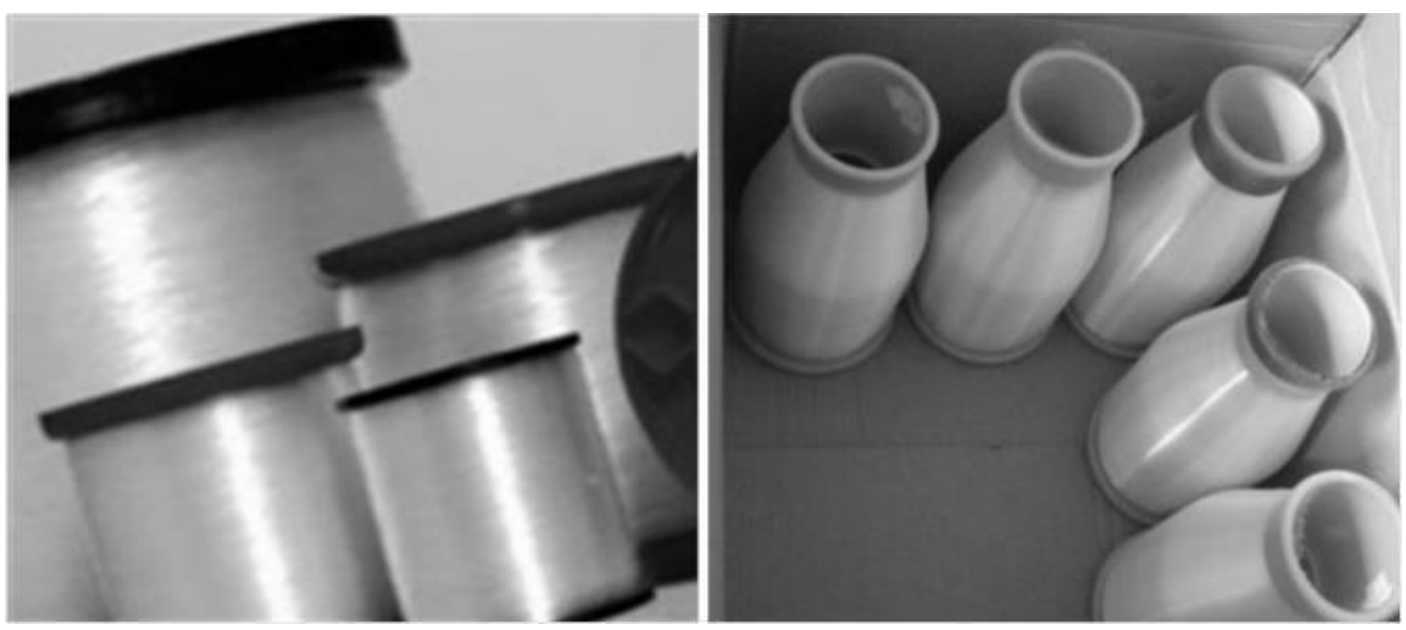

Fonte: Fabio Campos Fatalla a partir de imagens diversas, 2016 
- Fios multifilamentos: vários filamentos contínuos mantidos unidos com ou sem torção que podem ser lisos, texturizados ou texturizados a ar (figura 21).

Figura 21 - Fios multifilamento

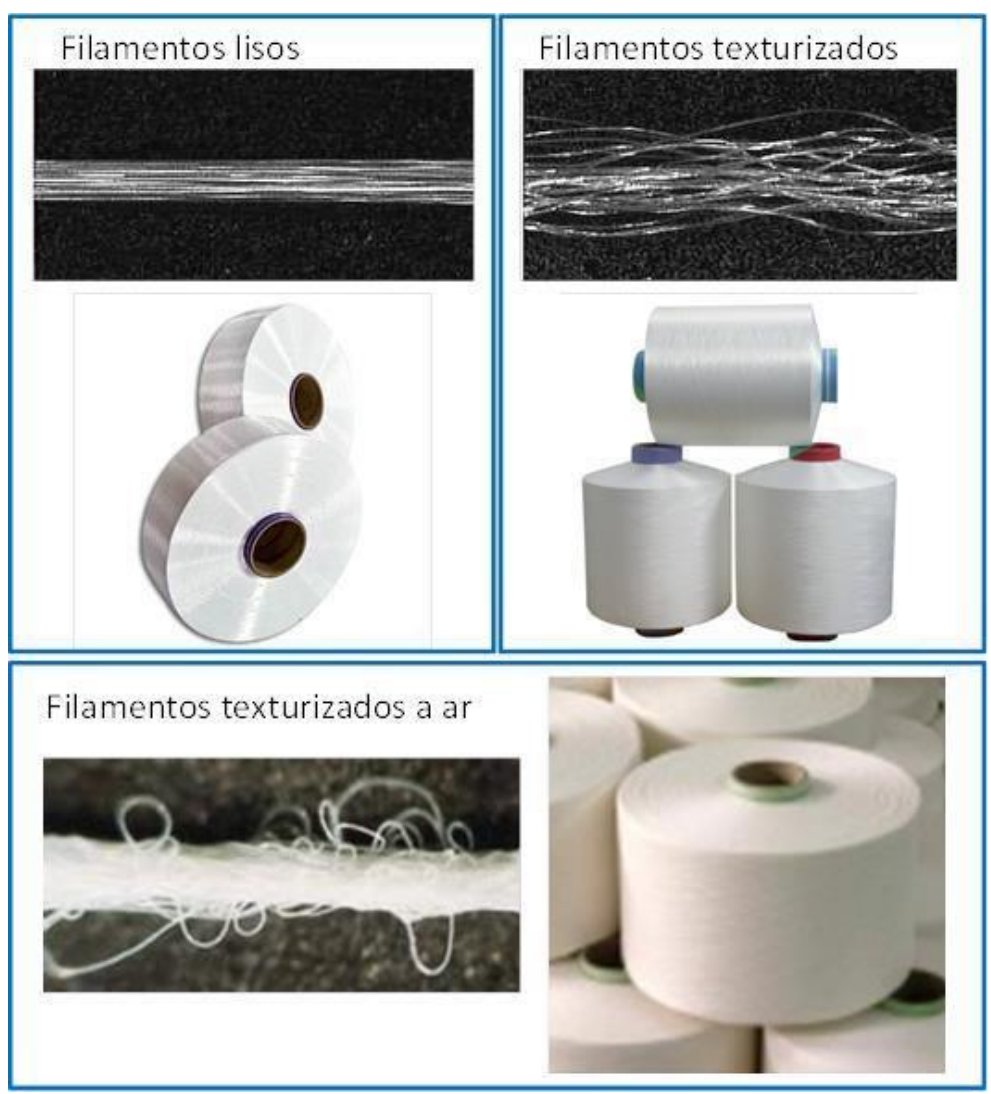

Fonte: Fabio Campos Fatalla a partir de imagens diversas, 2016

Com relação ao número de filamentos Guillén (2001) define que os fios multifilamentos podem ser classificados em convencional e microfibra (figura 22).

Figura 22 - Fios multifilamento convencional e microfibra

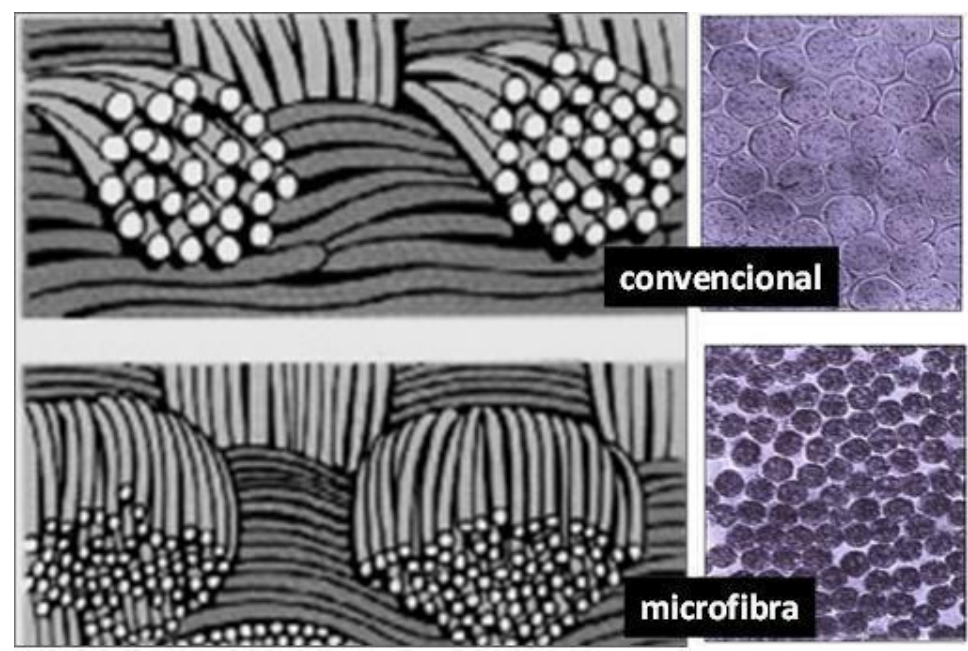

Fonte: Fabio Campos Fatalla a partir de imagens diversas, 2016 


\subsubsection{Fios torcidos e retorcidos}

São fios constituídos por um único fio singelo com torção (fio torcido) ou pela junção de vários cabos de fios singelos, normalmente por torção (fio retorcido). (ARAUJO e CASTRO, 1986)

- Fios torcidos no sentido S ou Z (figura 23)

Figura 23 - Fios torcidos "S" ou "Z"

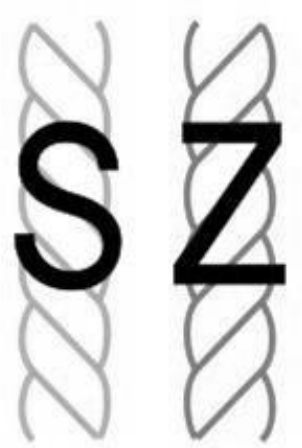

Fonte: Fabio Campos Fatalla, 2016

- Fios retorcidos: constituído por dois ou mais fios simples reunidos por retorcimento (figura 24).

Figura 24 - Fios retorcidos
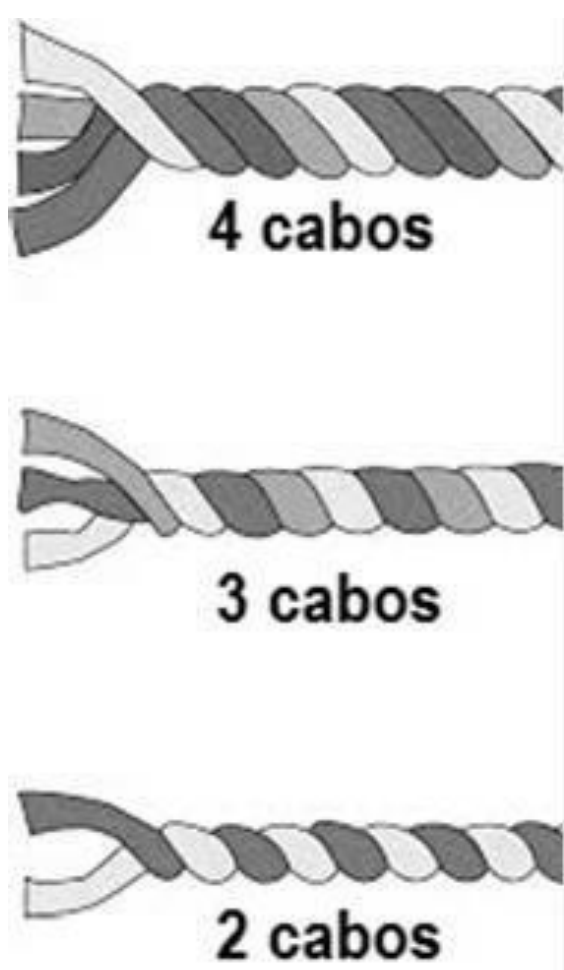

Fonte: Fabio Campos Fatalla, 2016 
- Fios retorcidos múltiplos: obtidos pela torção de dois ou mais fios retorcidos (figura 25).

Figura 25 - Fio retorcido múltiplo

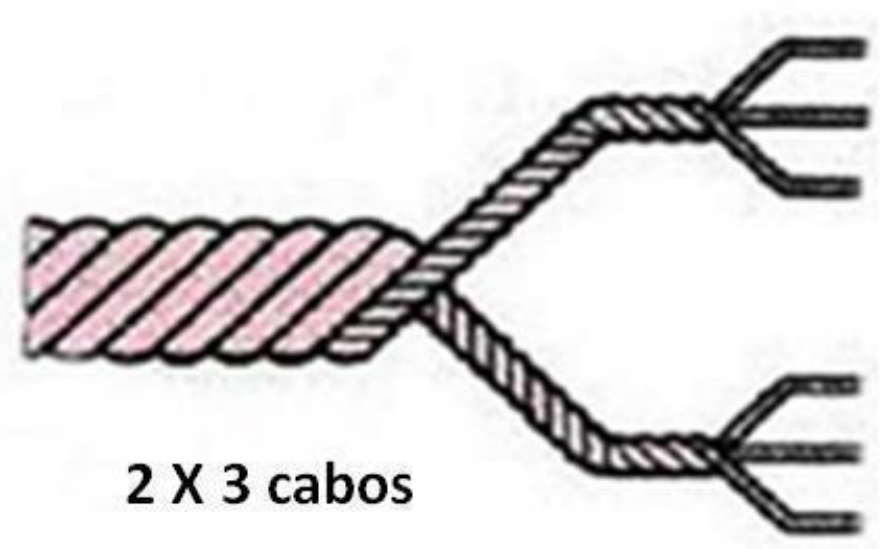

Fonte: Fabio Campos Fatalla, 2016

\subsubsection{Considerações sobre a classificação dos têxteis nos capítulos 50 a 55}

\subsubsection{Classificação dos produtos têxteis formados por misturas de matérias têxteis:}

A classificação de produtos têxteis incluídos nos capítulos 50 a 55 deve levar em conta inicialmente a matéria prima constituinte (NESH, 2008). No entanto, são bastante comuns artigos têxteis produzidos por misturas de duas ou mais matérias primas diferentes. Segundo Walczak (2002), essas misturas podem ser efetuadas em diferentes etapas dos processos têxteis:

- Antes ou durante a fiação - processo conhecido como mistura "íntima".

Exemplos comuns são as misturas de algodão e poliéster PES/CO 50/50\% e PES/CO 67/33\%.

- Durante a torção ou torção múltipla - fios de diferentes composições são torcidos juntos.

- Durante o tecimento do tecido - teares planos ou circulares são alimentados com fios de diferentes composições.

Nesses casos, de acordo com a NESH (2008) devem ser seguidas as seguintes regras: 
A. Os produtos devem ser classificados como se fossem constituídos inteiramente pela matéria têxtil predominante em peso na sua composição. Dessa forma, por exemplo, um artigo constituído de $75 \%$ algodão e $25 \%$ poliéster deve ser classificado como se fosse $100 \%$ algodão (capítulo 52) (figura 26).

Figura 26 - Exemplo de composição

\section{$75 \%$ Algodão}

\section{$25 \%$ Poliester}

Fonte: Fabio Campos Fatalla, 2016

Outro artigo composto, por exemplo, de 60\% algodão, $20 \%$ linho e $20 \%$ viscose deve também ser classificado como se fosse 100\% algodão (capítulo 52) (figura 27).

Figura 27 - Exemplo de composição

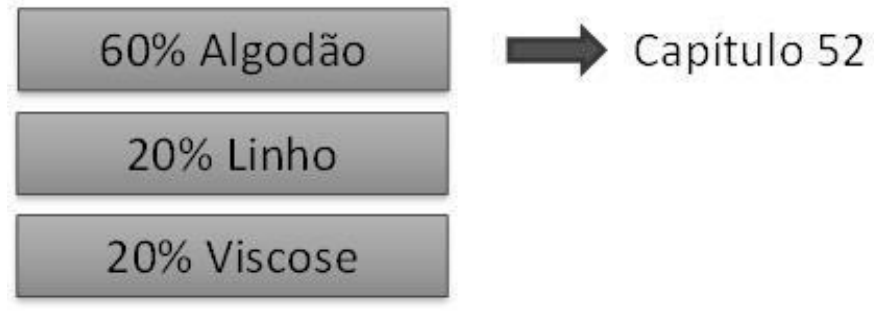

Fonte: Fabio Campos Fatalla, 2016

B. Quando nenhuma matéria predomine em peso, o produto é classificado como se fosse inteiramente constituído pela matéria têxtil que se inclui na posição situada em último lugar na ordem numérica dentre as suscetíveis de validamente se tomarem em consideração. Assim, um produto constituído de $50 \%$ algodão e $50 \%$ poliéster filamento, deverá ser classificado como se fosse $100 \%$ poliéster filamento (capítulo 54) (figura 28). 
Figura 28 - Exemplo de composição

\section{$50 \%$ Algodão}

$50 \%$ Poliéster

filamento

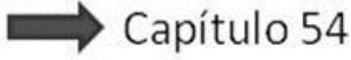

Fonte: Fabio Campos Fatalla, 2016

C. Para efeitos de classificação, matérias primas do mesmo capítulo consideram- se conjuntamente. Dessa forma devem-se somar os percentuais de composição de todas as matérias presentes no produto que pertençam ao mesmo capítulo, como:

- todos os fios de origem de pelos e lã (capítulo 51),

- todas as outras fibras vegetais exceto algodão (capítulo 53),

- todos os filamentos contínuos sintéticos ou artificiais (capítulo 54),

- todas as fibras descontinuas sintéticas ou artificiais (capítulo 55). Assim, por exemplo, num produto contendo $40 \%$ de algodão, $30 \%$ de poliéster (fibra sintética descontinua) e $30 \%$ de viscose (fibra artificial descontinua) devemse somar os percentuais de composição de poliéster e viscose, que perfaz $60 \%$ tornando-os majoritários no artigo que deverá ser classificado como se fosse totalmente constituído de fibras descontínuas artificiais ou sintéticas (capítulo 55) (figura 29).

Figura 29 - Exemplo de composição

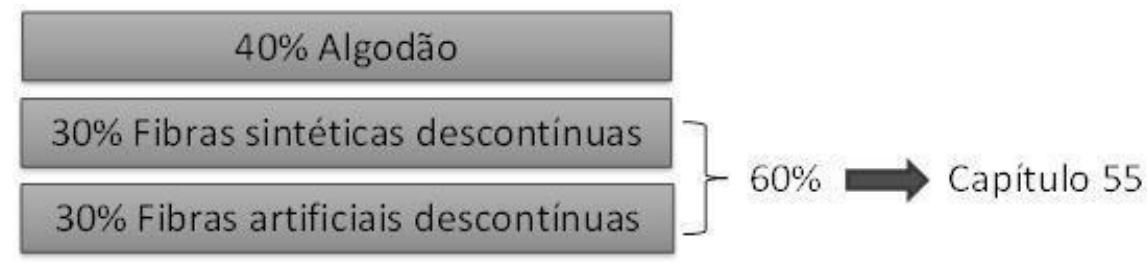

Fonte: Fabio Campos Fatalla, 2016

Em outro exemplo, num produto composto de $40 \%$ poliéster, 35\% lã penteada e $25 \%$ pelos finos devem ser somados os percentuais de lã e pelos que perfazem $60 \%$. Então a matéria prima majoritária no artigo é a do capítulo 
51 (lã, pelos finos ou grosseiros; fios e tecidos de crina) (figura 30).

Figura 30 - Exemplo de composição

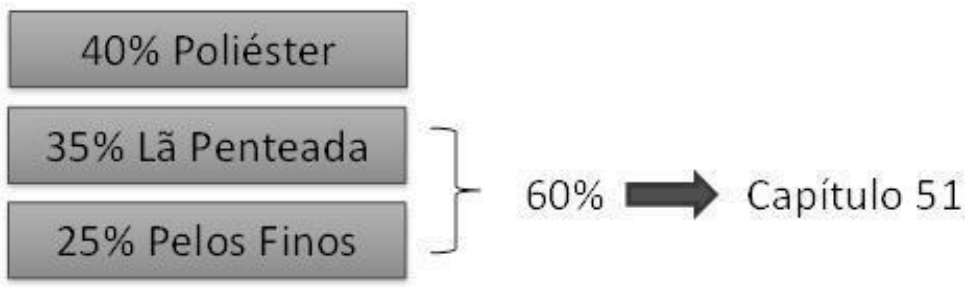

Fonte: Fabio Campos Fatalla, 2016

D. Quando os capítulos 54 e 55 devam ambos ser levados em consideração em relação a outro capítulo, estes dois capítulos devem ser tratados como um único e mesmo capítulo.

O exemplo da figura 31 , mostra um produto composto de $35 \%$ de poliéster filamento (cap. 54), $25 \%$ fibras de viscose (cap. 55) e $40 \%$ de algodão. $O$ percentual somado das matérias primas dos capítulos 54 e 55 perfaz $60 \%$, portanto maior que o percentual de algodão. Assim 0 artigo deverá ser classificado num desses dois capítulos (54 ou 55), nesse caso no capítulo 54 por que apresenta percentual maior que o capítulo 55.

Figura 31 - Exemplo de composição

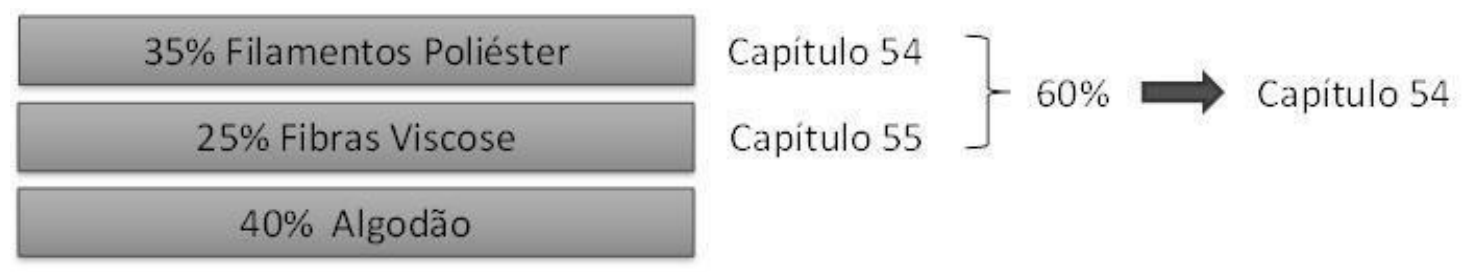

Fonte: Fabio Campos Fatalla, 2016

Outro exemplo (figura 32) mostra um produto onde, assim como no caso anterior, a soma das matérias dos capítulos 54 e 55 supera as demais (capitulo 51). Nesse caso a classificação final será no capitulo 55 pois como os percentuais dos capítulos 54 e 55 são iguais, vale a classificação de ordem numérica mais alta. 
Figura 32 - Exemplo de composição

\begin{tabular}{|c|}
\hline $35 \%$ Filamentos Poliéster \\
\hline $35 \%$ Fibras Acrilicas \\
\hline $12 \%$ Lã cardada \\
\hline $18 \%$ Lã penteada \\
\hline
\end{tabular}

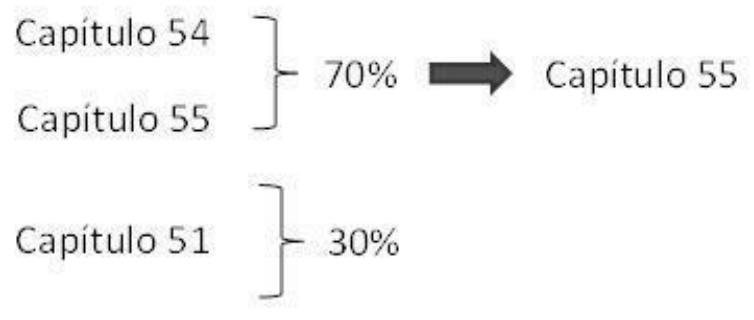

Fonte: Fabio Campos Fatalla, 2016

\subsubsection{Considerações sobre fios}

\subsection{Fios acondicionados para venda ao varejo:}

Uma das distinções abrangida nas posições dos capítulos 50 a 55 refere-se ao tipo de apresentação dos fios, no sentido de tratar-se de embalagem própria para venda ao varejo ou não (nesse caso para uso em processos industriais).

O quadro da figura 33 mostra as especificações de apresentações para venda no varejo segundo a NESH (2008):

Figura 33 - Fios acondicionados para venda no varejo

\begin{tabular}{|l|l|}
\hline Tipo de embalagem & Tamanho do suporte (peso máx. incluindo o suporte) \\
\hline $\begin{array}{l}\text { Cartões, bobinas, tubose } \\
\text { suportes semelhantes. }\end{array}$ & $\begin{array}{l}85 \mathrm{~g} \text { - fios e desperdícios de seda ou de filamentos } \\
\text { sintéticos ou artificiais } \\
125 \mathrm{~g} \text { - outros fios }\end{array}$ \\
\hline Bolas, novelos ou meadas. & $\begin{array}{l}85 \mathrm{~g} \text { - fios de filamentos sintéticos ou artificiais com } \\
\text { menos de } 3000 \text { dtex, seda e desperdícios de seda. } \\
125 \mathrm{~g} \text { - outros fios c/ menos de 2000 dtex } \\
500 \mathrm{~g} \text { - outros fios }\end{array}$ \\
\hline $\begin{array}{l}\text { Meadas subdivididas em } \\
\text { meadas menores por um } \\
\text { ou mais divisores (meadas } \\
\text { independentes) }\end{array}$ & $\begin{array}{l}85 \mathrm{~g} \text { - fios e desperdicios de seda ou de filamentos } \\
\text { sinteos ourtificiais } \\
\text { (Nota: pesos de cada subdivisão) }\end{array}$ \\
\hline
\end{tabular}

Fonte: Fonte: Fabio Campos Fatalla com base na NESH, 2016

\subsection{Linhas de costura:}

Para efeito de classificação são considerados como linha de costura (figura 34) os fios retorcidos ou retorcidos múltiplos que preencham simultaneamente as seguintes condições: 
- Apresentarem-se em suportes (bobinas, tubos, cones, carreteis, etc.) com peso não superior a $1.000 \mathrm{~g}$, incluído o suporte;

- Encontrarem-se acabados, tendo em vista a sua utilização como linha para costurar;

- Apresentarem torção final em "Z".

Figura 34 - Linhas de costura

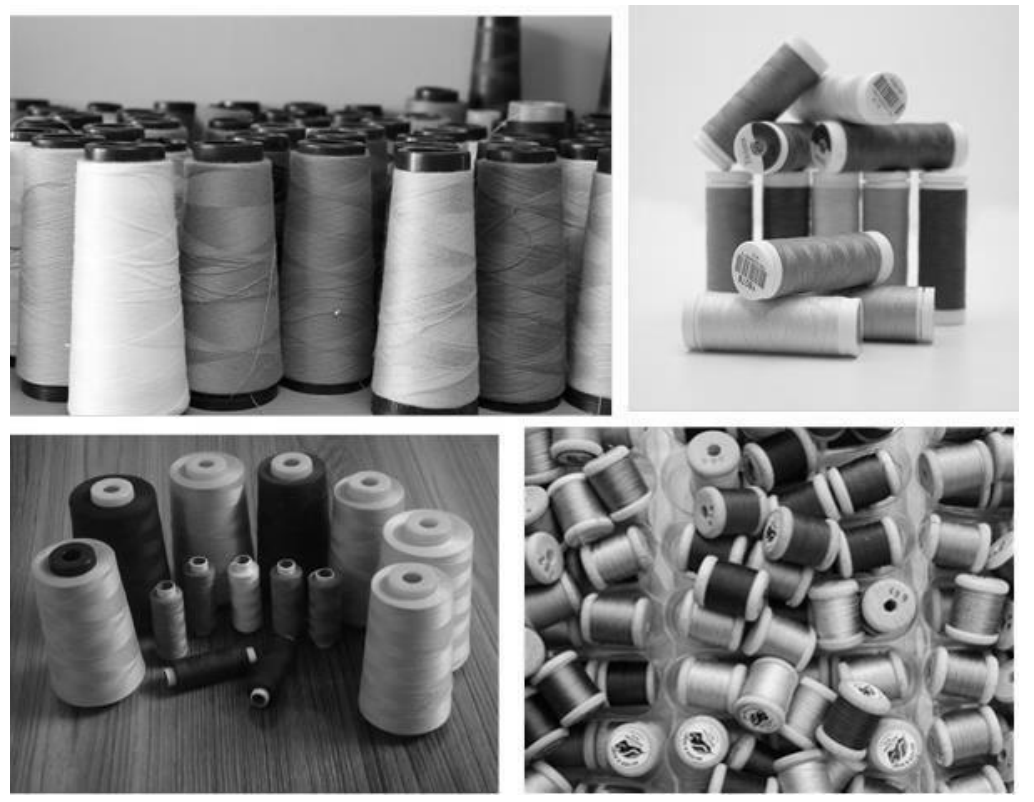

Fonte: Fabio Campos Fatalla a partir de imagens diversas, 2016

\subsection{Fios de alta tenacidade:}

Consideram-se fios de alta tenacidade aqueles cuja tenacidade, expressa em cN/tex, seja superior aos seguintes limites:

- Fios simples de poliamida ou de poliéster: $60 \mathrm{cN} / \mathrm{tex}$

- Fios retorcidos ou retorcidos múltiplos de poliéster: $53 \mathrm{cN} / \mathrm{tex}$

- Fios simples, retorcidos ou retorcidos múltiplos de viscose: 27 cN/tex

\subsubsection{Considerações sobre os tecidos}

\subsection{Definição de tecidos:}

Nos Capítulos 50 a 55, o termo tecido designa os produtos obtidos por entrecruzamento, em teares de urdidura e de trama, de fios têxteis (quer estes fios sejam considerados como fios dos Capítulos 50 a 55, quer como cordéis da posição 
56.07), ou de mechas, monofilamentos ou lâminas e formas semelhantes do Capítulo 54, de fios denominados "de cadeia" (chainette), de fitas estreitas, de entrançados ou de fitas sem trama em fios ou fibras paralelizadas e colados etc., desde que:

- não se trate de tapetes e outros revestimentos de pavimentos (Capítulo 57)

- não se trate de veludos, pelúcias ou chenille, atoalhados, tapeçarias, etc.

- não sejam revestidos, impregnados, nem de uso técnico,

- não sejam confeccionados

\subsection{Estrutura dos tecidos:}

Os tecidos são formados pelo entrelaçamento de fios de urdume e trama, (ARAUJO e CASTRO, 1986) como mostrado na figura 35. Na NESH utiliza-se o termo urdidura (português de Portugal) ao invés de urdume (português do Brasil).

Figura 35 - Estrutura do tecido

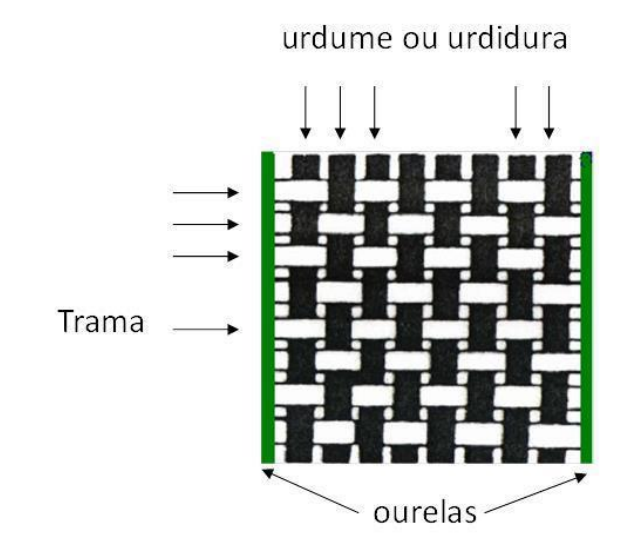

Fonte: adaptado de autor Araujo e Castro (1986)

\subsubsection{Considerações sobre acabamentos de tecidos}

Os tecidos englobados pelos capítulos 50 a 55 têm suas posições divididas em sub posições conforme segue:

- Tecidos crus:

São os tecidos que não tenham sofrido nem branqueamento, nem tintura, nem estampa.

- Tecidos branqueados:

São os tecidos que tenham sido branqueados ou tingidos de branco ou constituídos por fios branqueados, ou constituídos por fios crus e fios branqueados.

- Tecidos tintos: 
São tingidos de cor diferente do branco em uma única cor uniforme, ou constituídos por fios coloridos de uma única cor uniforme.

- Tecidos de fios de diversas cores (figura 36):

São constituídos por fios de diferentes cores ou por fios de tons diferentes de uma mesma cor, com exclusão da cor natural das fibras constitutivas. Normalmente enquadram-se aqui os tecidos listrados e xadrezes obtidos não por estampa.

Figura 36 - Tecidos de diversas cores
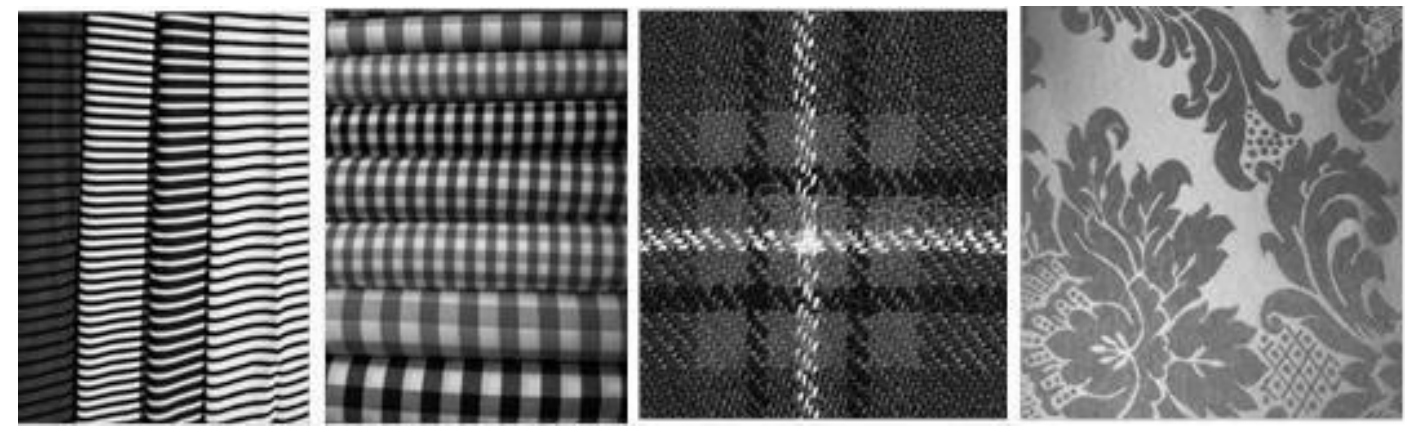

Fonte: Fabio Campos Fatalla a partir de imagens diversas, 2016

- Tecidos estampados (figura 37):

São os tecidos estampados na peça, mesmo que sejam constituídos por fios de diversas cores.

Figura 37 - Tecidos estampados
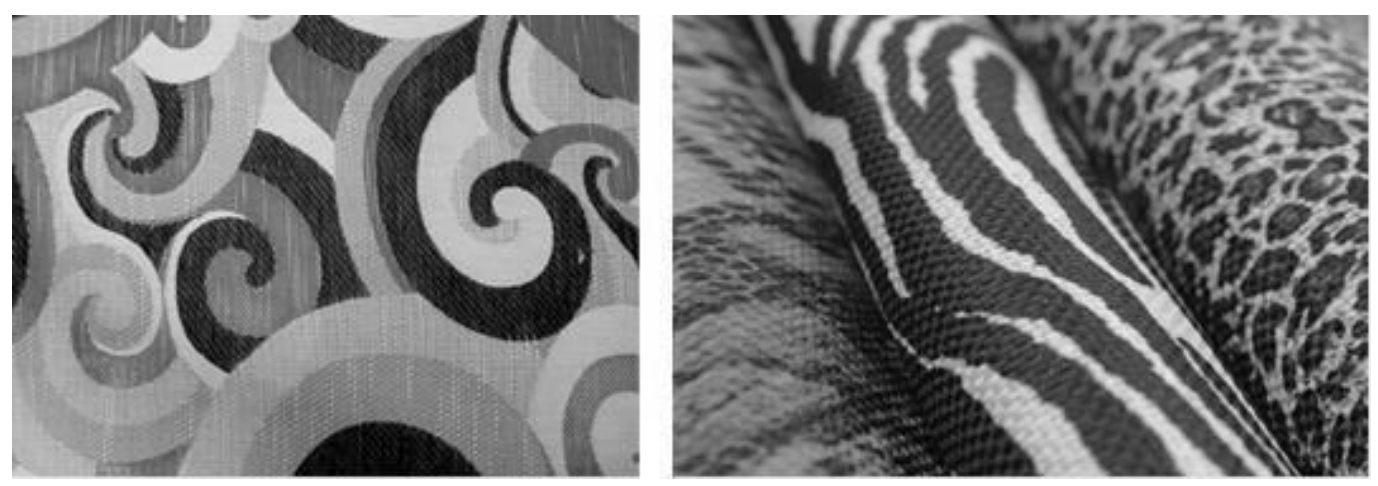

Fonte: Fabio Campos Fatalla a partir de imagens diversas, 2016

\subsubsection{Capítulo 50 - Seda}

O Capítulo 50 abrange a seda e as misturas desta com matérias têxteis assimiladas, desde os casulos até o tecido (figura 38).

Incluem-se neste capítulo as sedas das aranhas, a seda marinha (byssus) e 
o pelo de Messina (crina de Florença).

Figura 38 - Seda
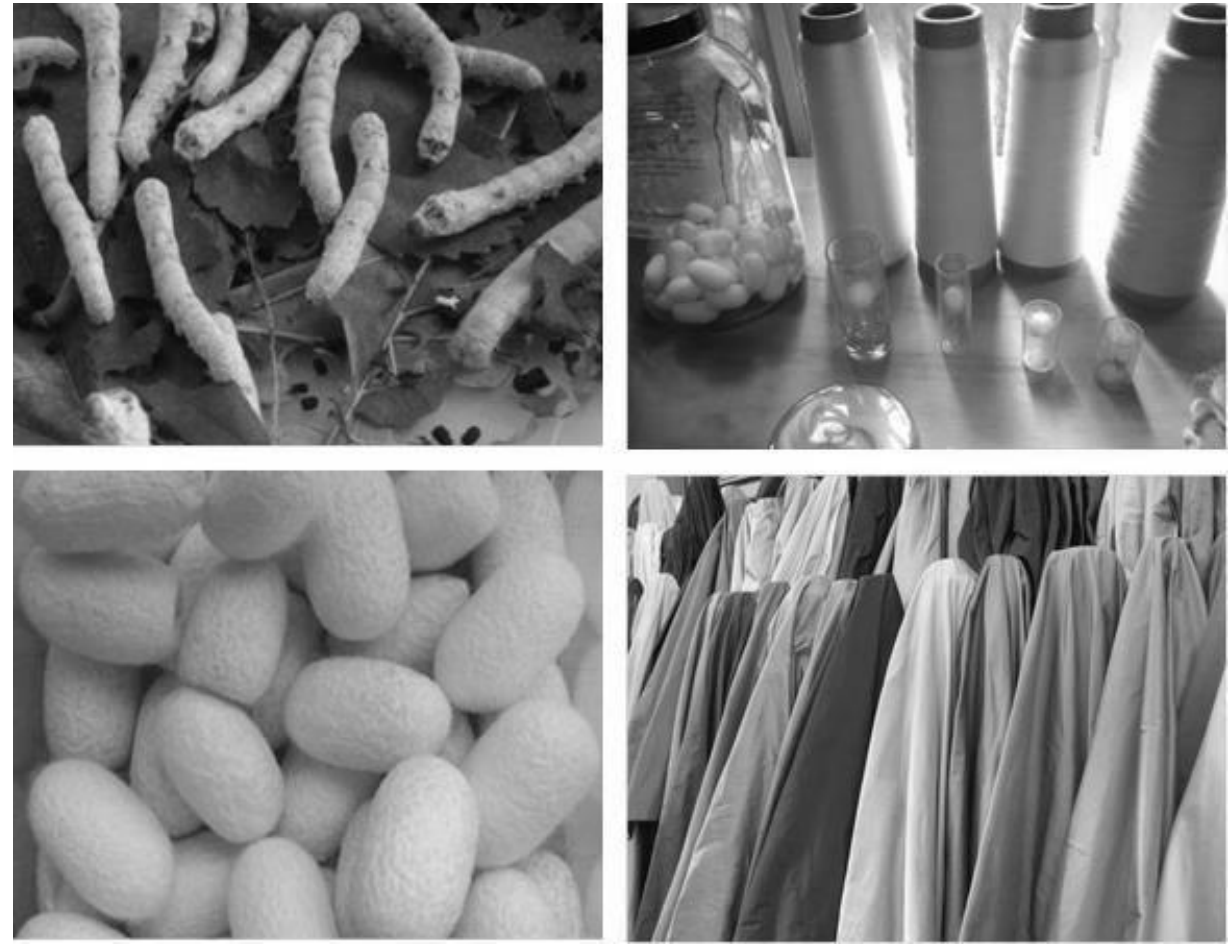

Fonte: Fabio Campos Fatalla a partir de imagens diversas, 2016

A figura 39 mostra as sete posições relativas ao capítulo 50:

Figura 39 - Posições do capítulo 50
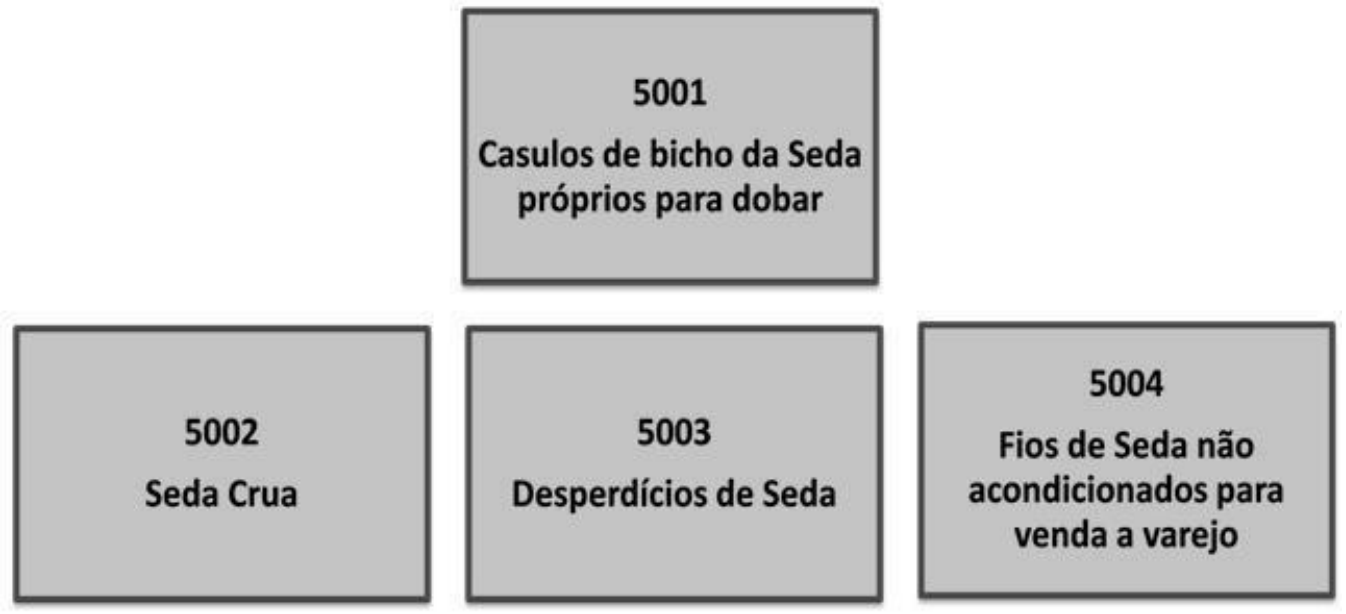

\section{5}

Fios de desperdício de seda não acondicionados para a venda a varejo
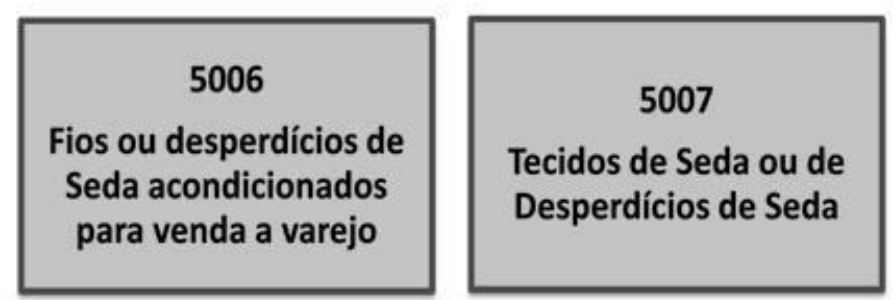

Fonte: Fabio Campos Fatalla com base na NESH, 2016 
Um tecido plano, por exemplo, composto de 15\% de filamentos de poliéster, $15 \%$ de fibras de viscose e $70 \%$ de seda será classificado na posição 5007 conforme mostrado na figura 40:

Figura 40 - Exemplo do capítulo 50
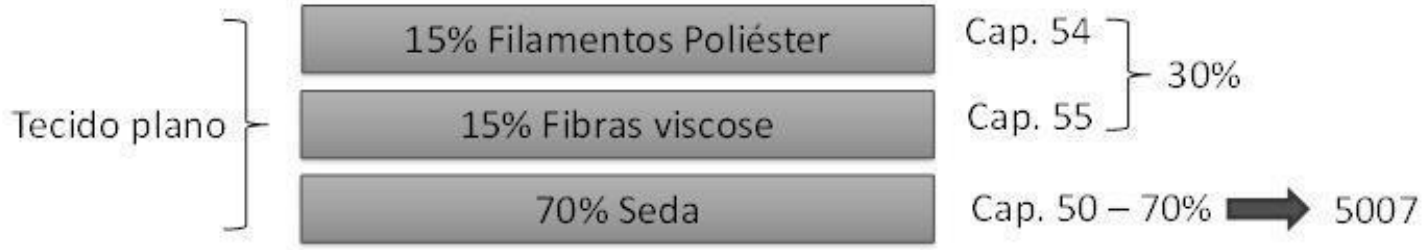

Fonte: Fabio Campos Fatalla, 2016

\subsubsection{Capítulo 51 - Lã, pelos finos ou grosseiros; fios e tecidos de crina}

Esse capítulo abrange, de um modo geral, a lã e os pelos, finos ou grosseiros, nas diversas fases de transformação, desde a fibra até o tecido, bem como os fios e tecidos de crina (figura 41).

Figura 41 - Lã
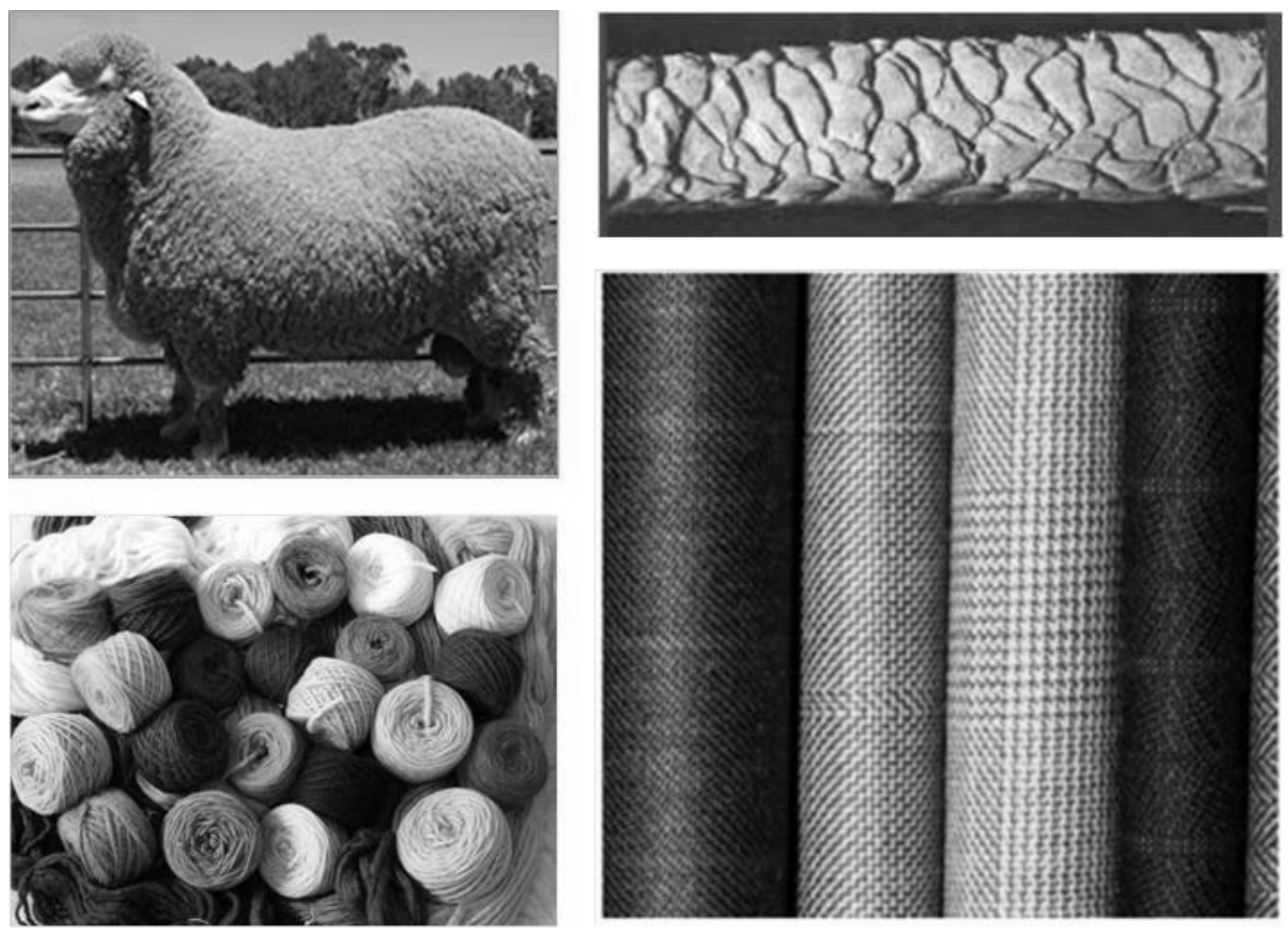

Fonte: Fabio Campos Fatalla a partir de imagens diversas, 2016 
Estão incluídos nesse capítulo:

- Lã: fibra natural que cobre os ovinos

- Pelos finos: os pelos de alpaca, Ihama, vicunha, camelo e dromedário, iaque, cabra angorá, Caxemira ou semelhantes

- Pelos grosseiros: os pelos dos animais não mencionados

anteriormente. Estão excluídos desse capítulo:

- Os pelos e cerdas utilizados na fabricação de pincéis, escovas e semelhantes.

A figura 42 mostra as posições do capítulo 51 :

Figura 42 - Posições do capítulo 51
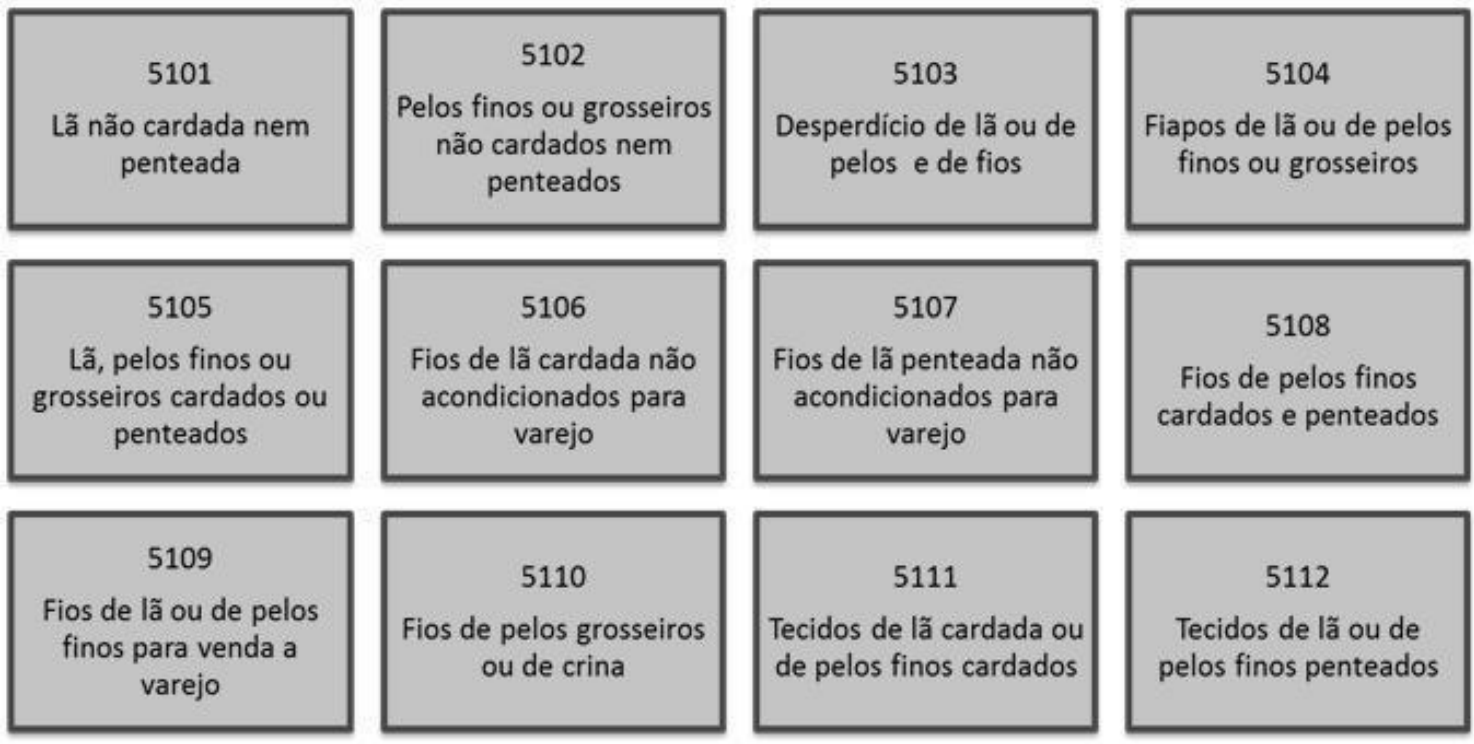

\section{3}

Tecidos de pelos grosseiros ou de crina

Fonte: Fabio Campos Fatalla com base na NESH, 2016

Por exemplo, um novelo composto de fio 65\% Lã e 35\% fibra Acrílica conforme mostrado na figura 43, deverá ser classificado na posição 5109:

- Capítulo 51, pois a composição majoritária do produto é lã;

- Posição 5109, pois trata-se de fio de lã para venda a varejo (novelo) 
Figura 43 - Exemplo do capítulo 51

Novelo $\}$

$35 \%$ Fibras Acrilicas

$65 \%$ Lã
Cap. 55

Cap. 51

5109

Fonte: Fabio Campos Fatalla, 2016

\subsubsection{Capítulo 52 - Algodão}

Esse capítulo inclui o algodão nas suas diversas fases de transformação, desde a fibra até o tecido, além de produtos mistos semelhantes ao algodão (figura 44).

Figura 44 - Algodão

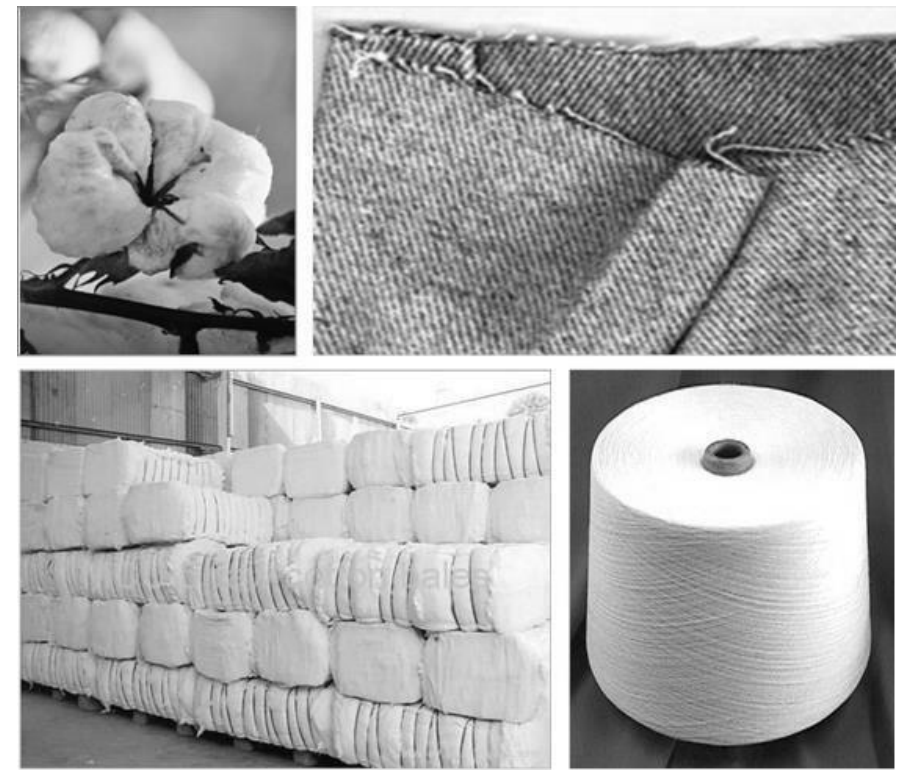

Fonte: Fabio Campos Fatalla a partir de imagens diversas, 2016

A figura 45 mostra as posições do capítulo 52: 
Figura 45 - Posições do capítulo

52
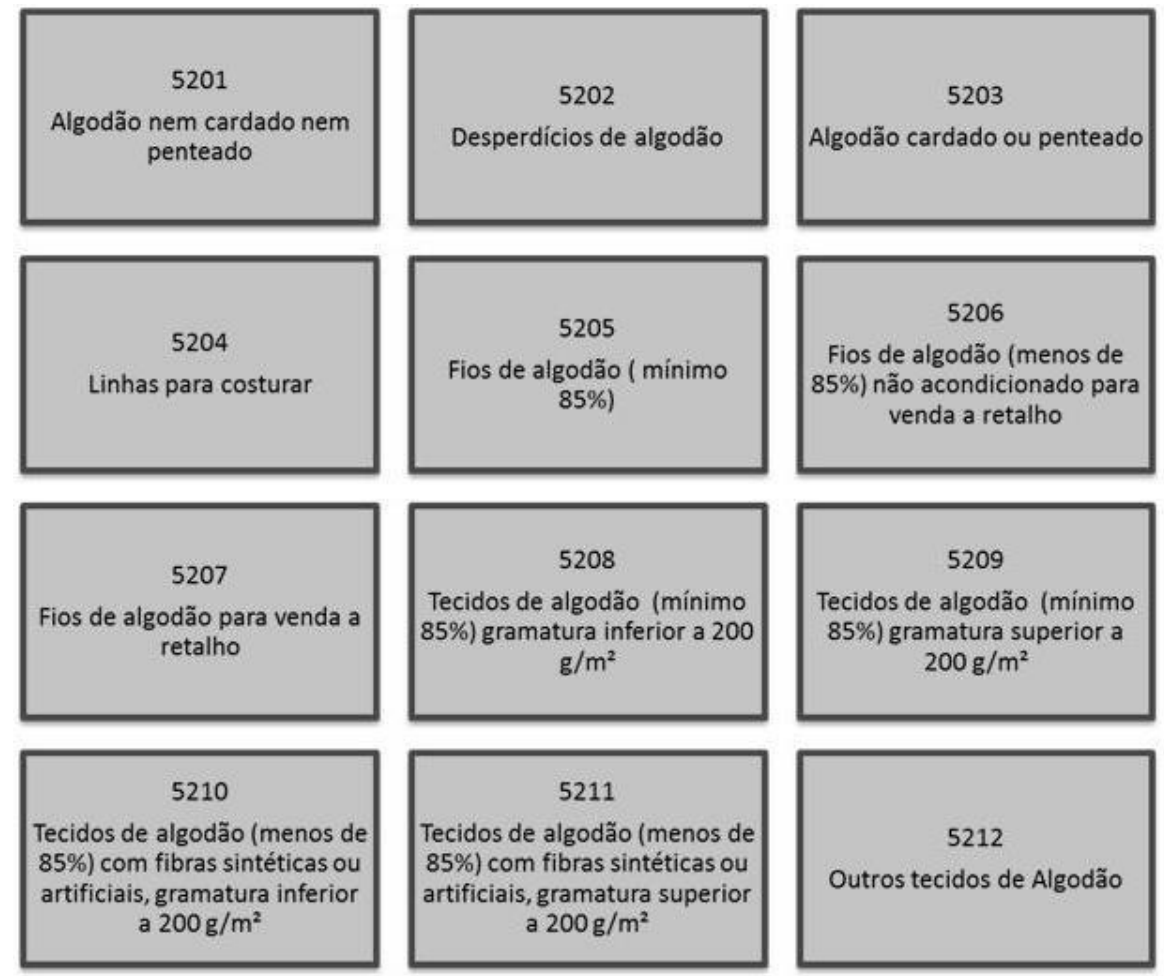

Fonte: Fabio Campos Fatalla com base na NESH, 2016

Nos tecidos de algodão estão incluídos os tecidos conhecidos por índigo denim. Nesses tecidos três construções são mais utilizadas: a sarja $3 \times 1$, a sarja $2 \times 1$, a sarja interrompida (sarja quebrada ou cetim de 4) e a tela (Chambray). Os fios de urdume (100\% algodão) são tintos com corante índigo e a trama de algodão cru. As tramas podem ser também de fios mistos com elastano, com fibras e filamentos sintéticos e/ou artificiais.

\subsubsection{Capítulo 53 - Outras fibras têxteis vegetais; fios de papel e tecidos de fios de papel}

Esse capítulo engloba as matérias têxteis vegetais, exceto o algodão, nas suas diversas fases de transformação na indústria têxtil, incluídos os tecidos (figura 46).

Fazem parte desse capítulo fibras como: linho, juta, rami, cânhamo, sisal, 
cairo, abacá, coco, etc.

Figura 46 - Outras fibras vegetais
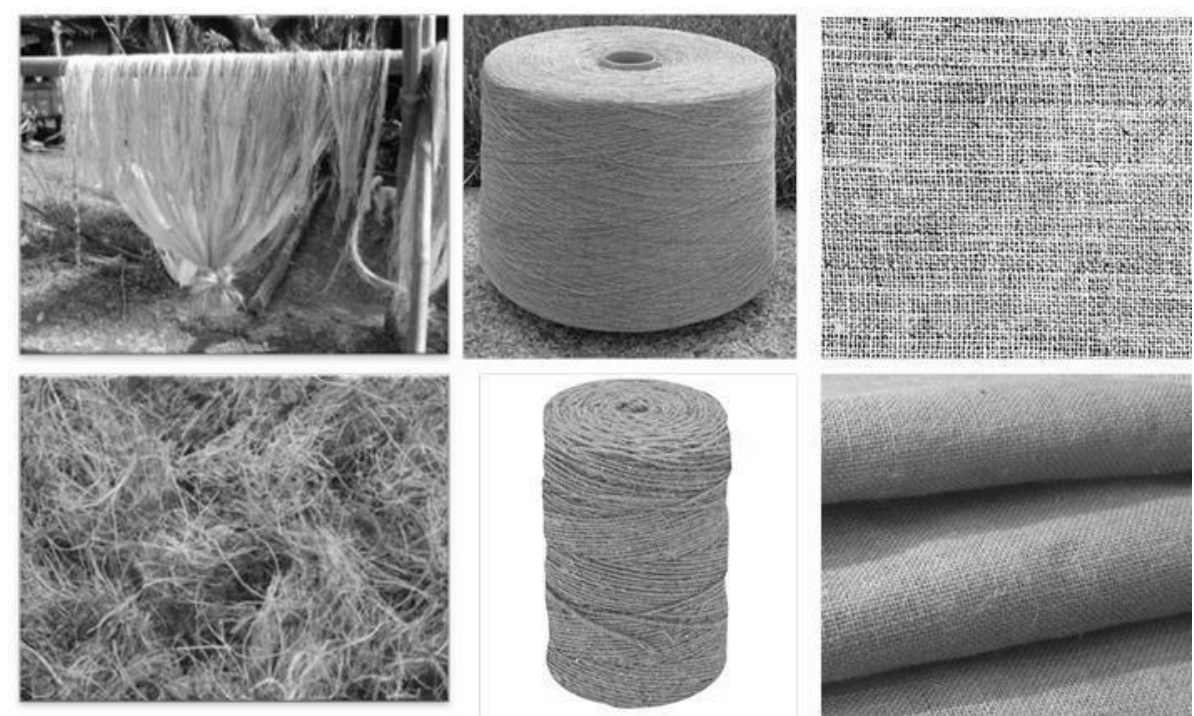

Fonte: Fabio Campos Fatalla a partir de imagens diversas, 2016

Os fios para serem classificados nesta posição, não devem satisfazer às definições de cordéis, cabos, etc. da posição 56.07, ou seja, não se enquadram nesse capítulo as cordas e cabos desses materiais.

A figura 47 mostra as posições que fazem parte desse capítulo:

Figura 47 - Posições do capítulo

53

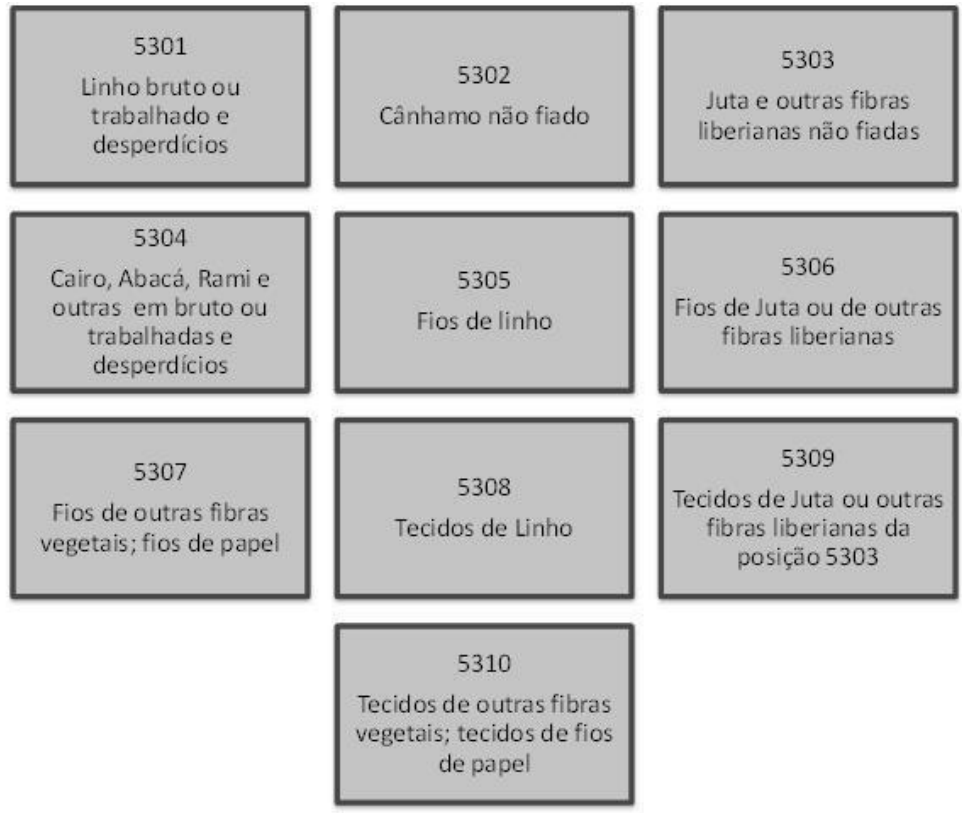

Fonte: Fabio Campos Fatalla com base na NESH, 2016 


\subsubsection{Capítulo 54 - Filamentos sintéticos ou artificiais; lâminas e formas} semelhantes de matérias têxteis sintéticas ou artificiais

O presente Capítulo abrange os filamentos e monofilamentos sintéticos ou artificiais (figura 48), bem como os fios e os tecidos obtidos a partir desses filamentos.

Figura 48 - Filamentos sintéticos e artificiais

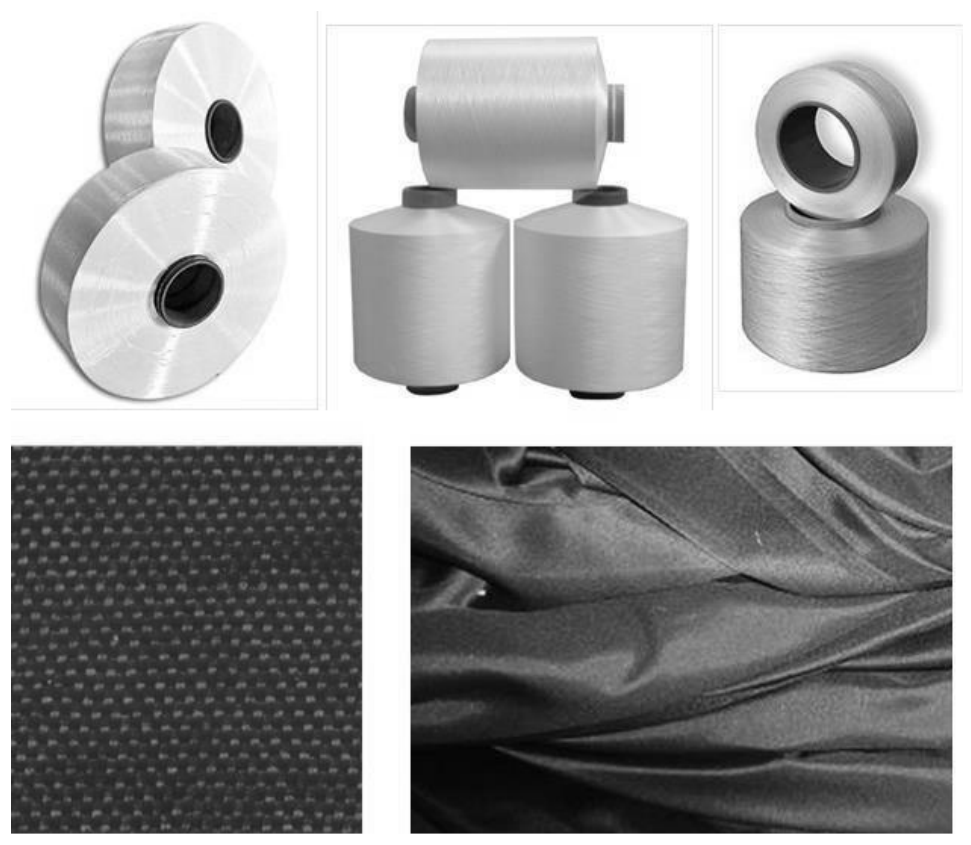

Fonte: Fabio Campos Fatalla a partir de imagens diversas, 2016

Estão excluídos desse capítulo:

- Os fios utilizados para limpar os espaços interdentais (fios dentais), em embalagens individuais para venda a retalho,

- Os fios e cordas da posição 40.07,

- As fibras descontínuas, os fios e os tecidos de fibras descontínuas, bem como os desperdícios de filamentos, os desperdícios de fios e os fiapos,

- As fibras de carbono e suas obras da posição 68.15,

- As fibras de vidro e suas obras da posição 70.19.

A figura 49 mostra as posições do capítulo 54: 
Figura 49 - Posições do capítulo 54

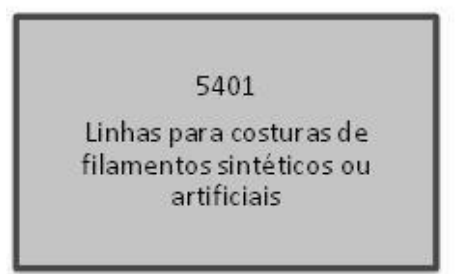

5404

Mon ofilamentos sintéticos com mais de 67 Dtex, diâmetro inferior a $1 \mathrm{~mm}$; laminas de largura inferior a $5 \mathrm{~mm}$

\section{2}

Fios de filamentos sintéticos não acondicionados para venda a retalho incluindo os

monofilamentos com menos de 67 Dtex

\section{5}

Monofilamentos artificiais com mais de $67 \mathrm{D}$ tex, diâmetro inferior a $1 \mathrm{~mm}$; laminas de largura inferior a $5 \mathrm{~mm}$

\section{3}

Fios de filamentos artificiais sintéticos não acondicionados para venda a retalho incluindo os monofilamentos com menos de 67 Dtex

\section{6}

Fios de filamentos sintéticos ou ar tificiais para venda a retalho
5407

Tecidos de fios de filamentos sintéticos

\section{8}

Tecidos de fios de filamentos artificiais

Fonte: Fabio Campos Fatalla com base na NESH, 2016

\subsubsection{Capítulo 55 - Fibras sintéticas ou artificiais, descontínuas}

O presente Capítulo abrange as fibras descontínuas sintéticas ou artificiais bem como os fios e os tecidos obtidos a partir dessas fibras (figura 50).

Figura 50 - Fibras descontínuas
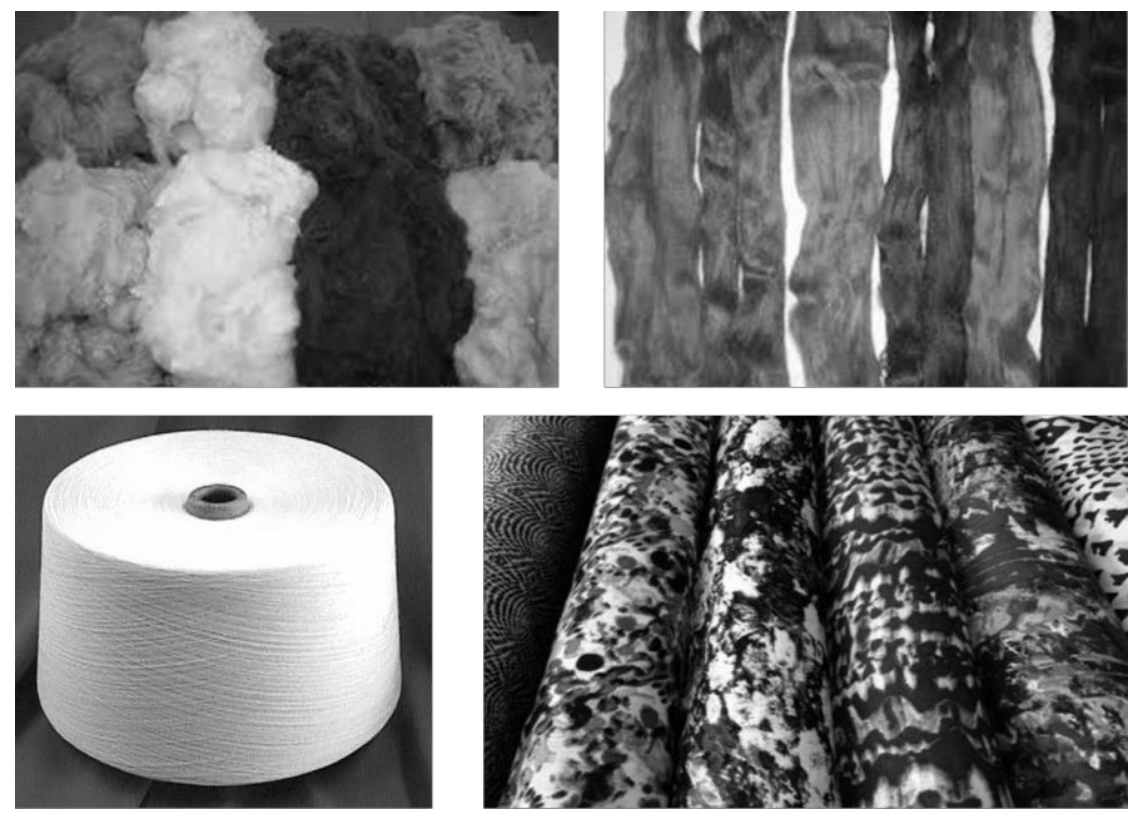

Fonte: Fabio Campos Fatalla a partir de imagens diversas, 2016 
Incluem-se nesse capítulo (nas posições 55.01 e 55.02) os cabos de filamentos sintéticos ou artificiais, constituídos por um conjunto de filamentos paralelos, de comprimento uniforme e igual ao dos cabos, que satisfaçam as seguintes condições:

- Comprimento do cabo superior a $2 \mathrm{~m}$

- Torção do cabo inferior a 5 voltas/m

- Título unitário dos filamentos inferior a 67 dtex

- Cabos de filamentos sintéticos estirado

- Alongamento não pode ser mais que $100 \%$ do seu comprimento

- Título total do cabo superior a 20.000 dtex

Os cabos cujo comprimento não exceda 2 metros classificam-se nas posições

\subsection{3 ou 55.04}

A figura 51 mostra as posições do capítulo 55:

Figura 51 - Posições do capítulo 55
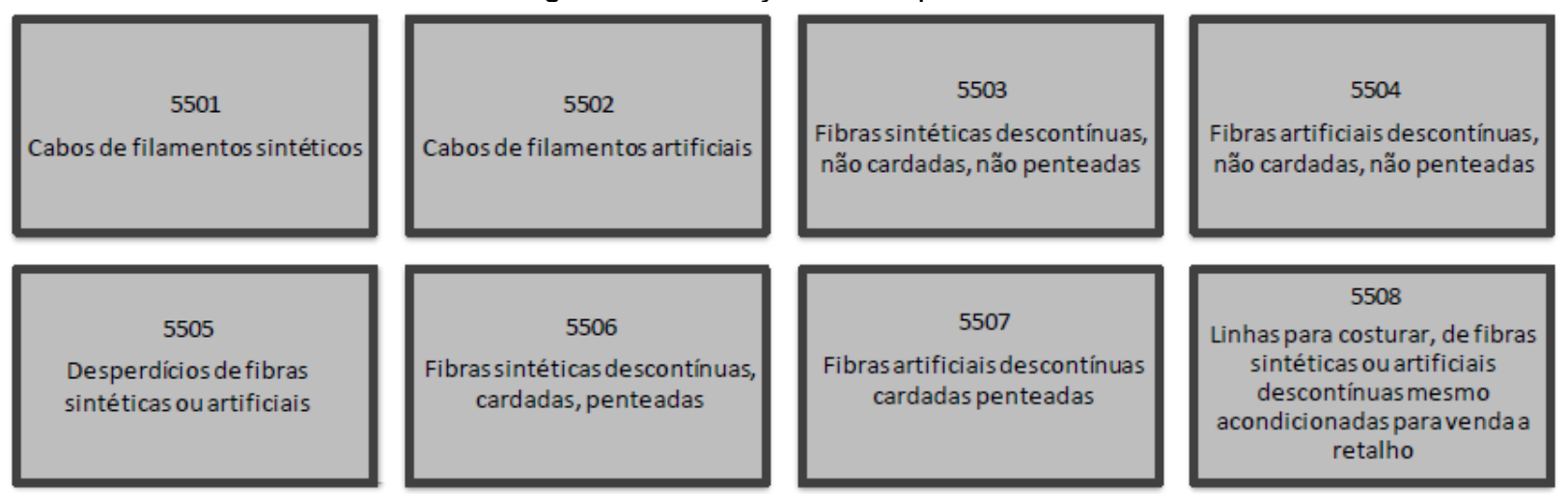

5505

Desperdícios de fibras sintéticas ou artificiais

\section{9}

Fios de fibras sintéticas descontínuas não acondicionados para vendaa retalho

\section{3}

Tecidos de fibras sintéticas descontínuas commenos de $85 \%$ combinados com algodão com gramatura inferior a 170 $\mathrm{g} / \mathrm{m}^{2}$

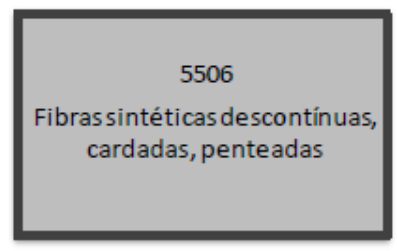

5510

Fios de fibras artificiais descontínuas não acondicionados paravenda a retalho

\section{4}

Tecidos de fibras sintéticas descontínuas com menos de $85 \%$ combinados com algodão com gramatura superior a 170 $\mathrm{g} / \mathrm{m}^{2}$

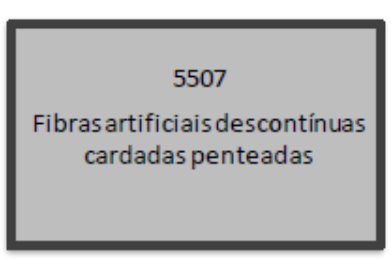

5511

Fios de fibras sintéticas ou artificiais descontínuos acondicionados paravendaa retalho

\section{5}

Outros tecidos de fibras sintéticas descontínuas
5512

Tecidos de fibras sintéticas descontínuas que tenham pelo menos $85 \%$ dessas fibras

menos $85 \%$ dessas fibras

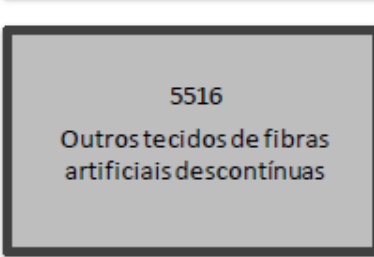

Fonte: Fabio Campos Fatalla com base na NESH, 2016

\subsection{CLASSIFICAÇÃO DOS TÊXTEIS NOS CAPÍTULOS 56 a 60}

Os capítulos 56 a 60 englobam os materiais têxteis especificados na figura 52 , 
com destaque para os tecidos de malha e os produtos confeccionados, além de feltros, não tecidos, tapetes, rendas, tecidos impregnados, etc.

Figura 52 - Capítulos 56 a 60

\begin{tabular}{|l|l|}
\hline 56 & $\begin{array}{l}\text { PASTAS (OUATES), FELTROS E FALSOS TECIDOS; FIOS ESPECIAIS; CORDÉIS, CORDAS } \\
\text { E CABOS; ARTIGOS DE CORDOARIA }\end{array}$ \\
\hline 57 & $\begin{array}{l}\text { TAPETES E OUTROS REVESTIMENTOS PARA PISOS (PAVIMENTOS), DE MATÉRIAS } \\
\text { TEXXTEIS }\end{array}$ \\
\hline 58 & $\begin{array}{l}\text { TECIDOS ESPECIAIS; TECIDOS TUFADOS; RENDAS; TAPEÇARIAS; PASSAMANARIAS; } \\
\text { BORDADOS }\end{array}$ \\
\hline 59 & $\begin{array}{l}\text { TECIDOS IMPREGNADOS, REVESTIDOS, RECOBERTOS OU ESTRATIFICADOS; } \\
\text { ARTIGOS PARA USOS TÉCNICOS DE MATÉRIAS TÊXTEIS }\end{array}$ \\
\hline 60 & TECIDOS DE MALHA \\
\hline
\end{tabular}

Fonte: Fabio Campos Fatalla com base na NESH, 2016

\subsubsection{Capítulo 56 - Pastas (ouates), feltros e falsos tecidos; fios especiais; cordéis, cordas e cabos; artigos de cordoaria}

As pastas ("ouates"), feltros e falsos tecidos, impregnados, revestidos ou recobertos de substâncias ou preparações como, por exemplo, perfumes ou cosméticos, sabões ou detergentes, pomadas, cremes ou preparações semelhantes, não devem ser consideradas nesse capítulo quando essas matérias têxteis sirvam apenas de suporte.

A figura 53 mostra as posições do capitulo 56.

Figura 53 - Posições do capítulo 56

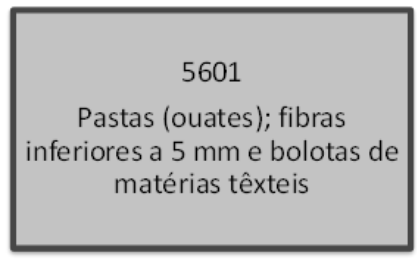

\section{4}

Fios e cordas de borracha recobertos de têxteis, laminas impregnados, revestidos, recobertos ou embainhados de borracha ou de plástico

\section{7}

Cordéis, cordas e cabos, entrelaçados ou não, mesmo impregnados, revestidos, recobertos ou embainhados de borracha ou de plástico
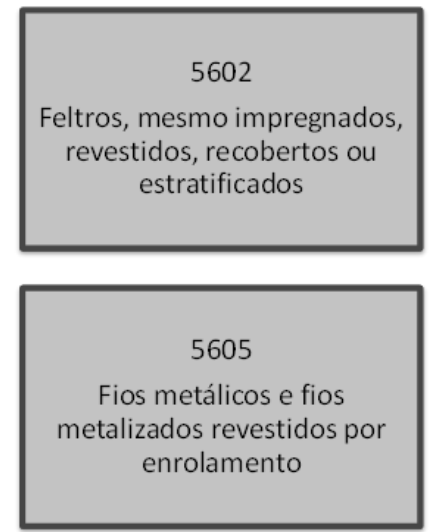

\section{8}

Redes de malhas com nós, obtidas a partir de cordéis, cordas ou cabos; redes de pesca

\section{3}

Falsos tecidos, mesmo impregnados, revestidos, recobertos ou estratificados

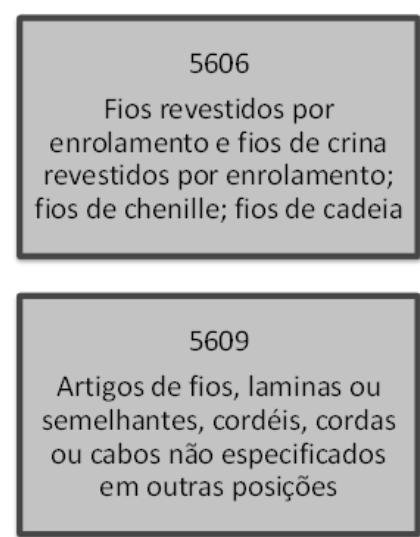




\subsubsection{Capítulo 57 - Tapetes e outros revestimentos para pisos (pavimentos), de matérias têxteis}

$\mathrm{Na}$ concepção da NCM, entende-se por tapetes e outros revestimentos para pisos qualquer revestimento cuja superfície de matéria têxtil seja a superfície exposta ao uso (figura 54).

Figura 54 - Tapetes e revestimentos
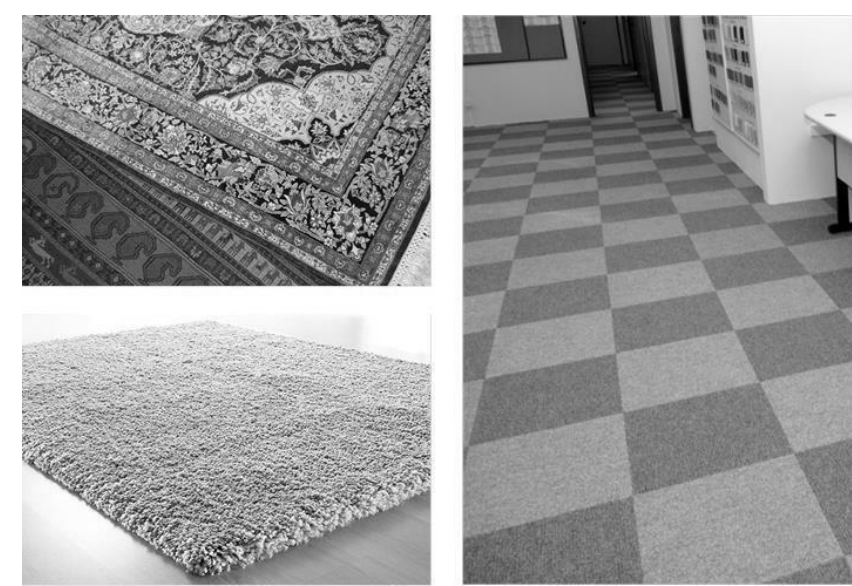

Fonte: Fabio Campos Fatalla a partir de imagens diversas, 2016

O capítulo 57 não abrange as mantas espessas comumente chamadas de forração que se interpõem entre o piso e os tapetes e outros revestimentos para pisos, nem os linóleos e similares.

As posições do capítulo 57 estão mostradas na figura 55. São divididas em função do tipo de tapete.

Figura 55 - Posições do capítulo 57
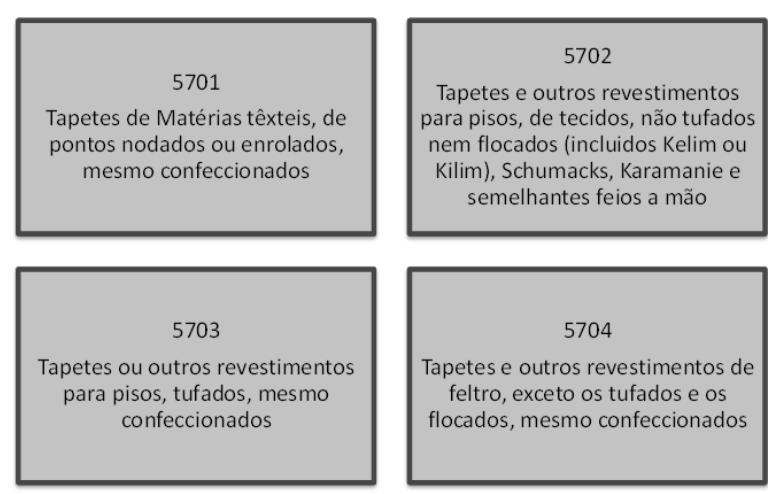

5705

Outros tapetes e revestimentos

para pisos de matérias têxteis,

mesmo confeccionados

Fonte: Fabio Campos Fatalla com base na NESH, 2016 


\subsubsection{Capítulo 58 - Tecidos especiais; tecidos tufados; rendas; tapeçarias;} passamanarias; bordados

Esse capítulo engloba uma série de tecidos e construções têxteis especiais que, em função de sua complexidade serão abordados individualmente em cada posição (figura 56).

Figura 56 - Posições do capítulo 58

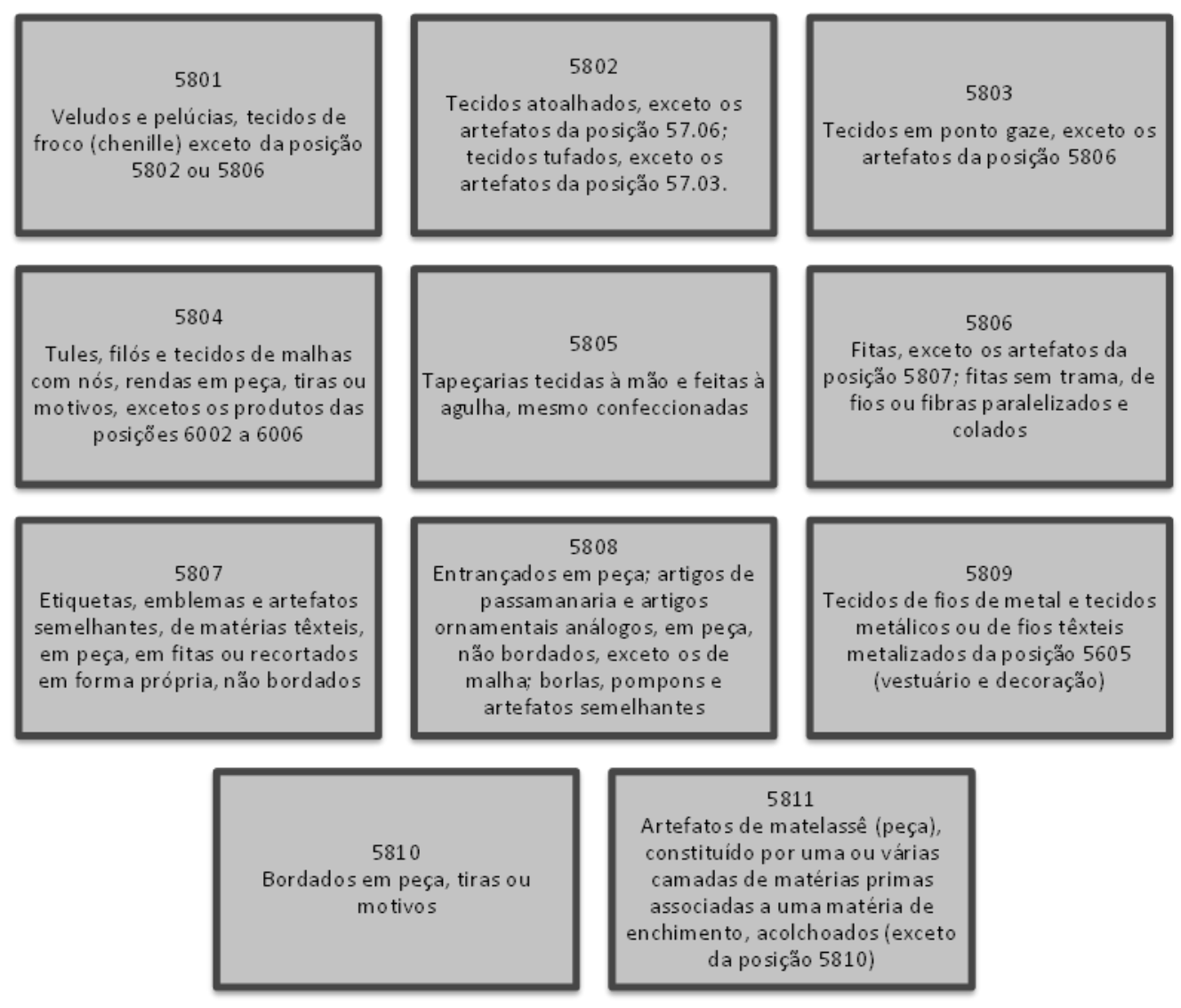

Fonte: Fabio Campos Fatalla com base na NESH, 2016

Não estão incluídos nesse capítulo os tecidos do Capítulo 59, impregnados, revestidos, recobertos ou estratificados, nem outros artefatos do Capítulo 59.

\subsubsection{Capítulo 59 - Tecidos impregnados, revestidos, recobertos ou estratificados; artigos para usos técnicos de matérias têxteis}

Esse capítulo inclui os tecidos que tenham sido impregnados, revestidos, recobertos ou estratificados por plásticos, colas ou outros materiais passíveis de 
serem utilizados para esse fim, além de têxteis para usos técnicos, conhecidos no mercado por têxteis técnicos.

Os têxteis técnicos são artigos feitos, em geral, a partir da tecnologia convencional (tecelagem, não tecido e malharia), usando matérias primas diferenciadas e processos especiais de acabamento, que geram produtos que podem ser utilizados em diversas áreas onde o desempenho técnico específico e/ou uma determinada característica seja desejada.

A figura 57 mostra as posições desse capítulo.

Figura 57 - Posições do Capítulo 59

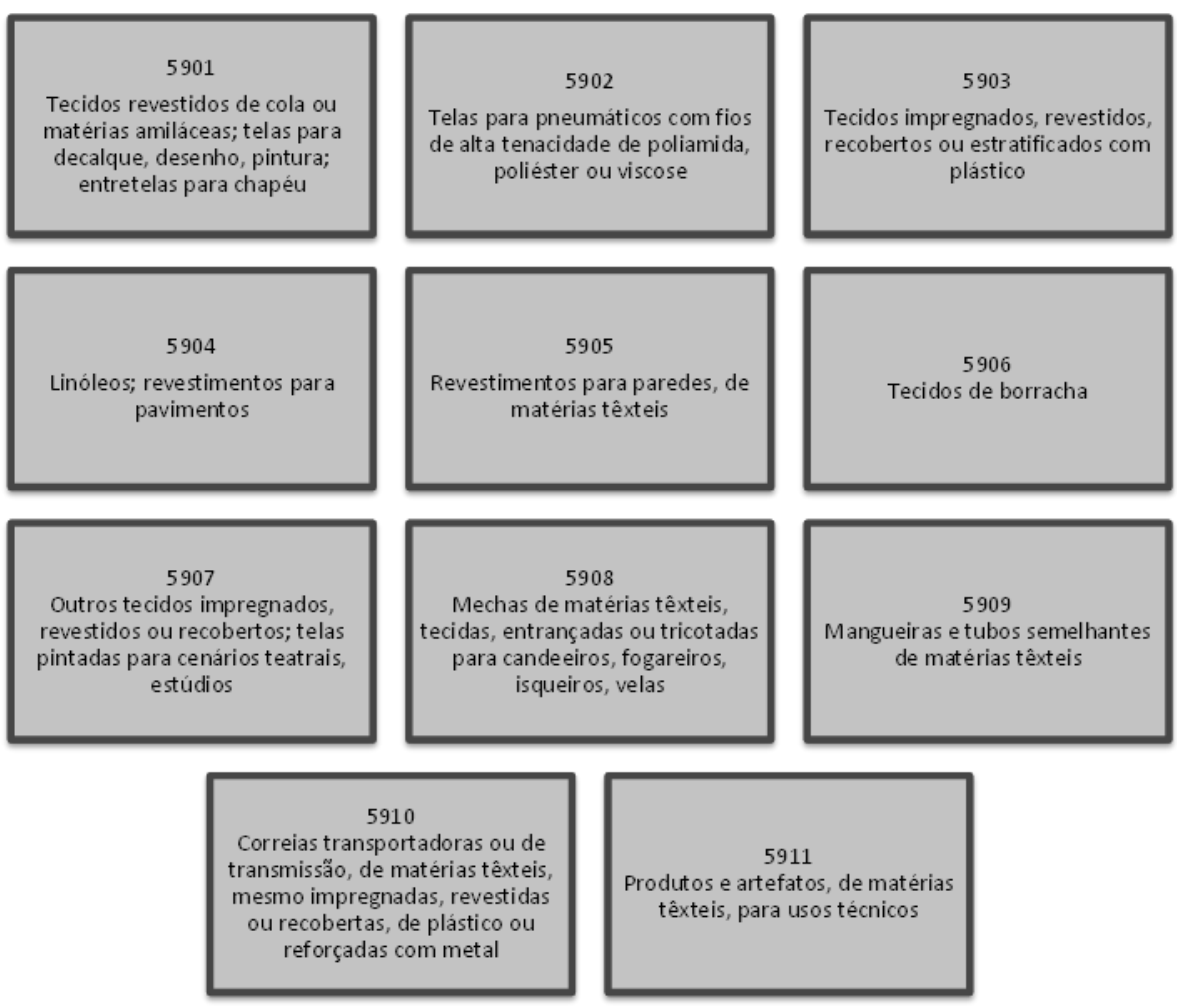

Fonte: Fabio Campos Fatalla com base na NESH, 2016

\subsubsection{Capítulo 60 - Tecidos de malha}

De acordo com a NESH (2008), o presente capítulo abrange os tecidos de malhas (não obtidos pelo processo de tecido plano de entrelaçamento de fios de urdidura e de trama) essencialmente produzidos por um dos processos de malhatrama ou malha-urdidura, conforme definidos por Spencer (2001): 
- Malha-trama (malharia de trama): Cada fio forma laçadas que se entrelaçam com as laçadas do fio anterior percorrendo o tecido no sentido da largura (figura 58). As malhas são facilmente desmalháveis.

Figura 58 - Malha-trama

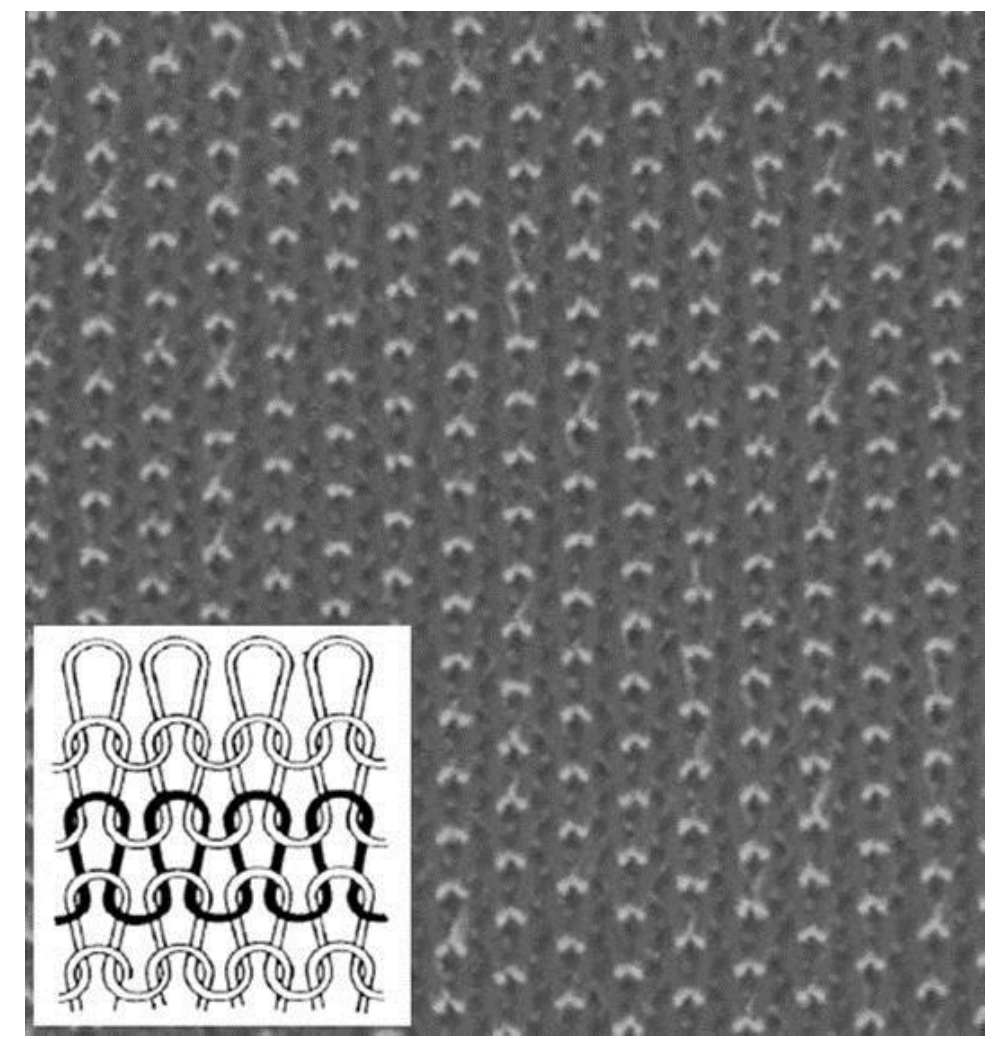

Fonte: Vasconcelos, 2015

A malharia de trama se divide em três tipos de máquinas principais:

- Máquinas circulares de grande diâmetro (26 a 38 polegadas): para produção de tecidos em rolo para confecção

- Máquinas circulares de pequeno diâmetro (3 a 16 polegadas): para produção de meias e peças de vestuário sem costura

- Máquinas retilíneas: para produção de peças de vestuário como pulovers, malhas de inverno, blusas, etc.

- Malha-Urdidura (malharia de urdume): Os fios de urdidura (urdume) formam laçadas que se entrelaçam com as laçadas uns dos outros e cada fio percorre $o$ tecido no sentido do comprimento. As malhas são quase sempre indesmalháveis (figura 59). 
Figura 59 - Malha-urdidura

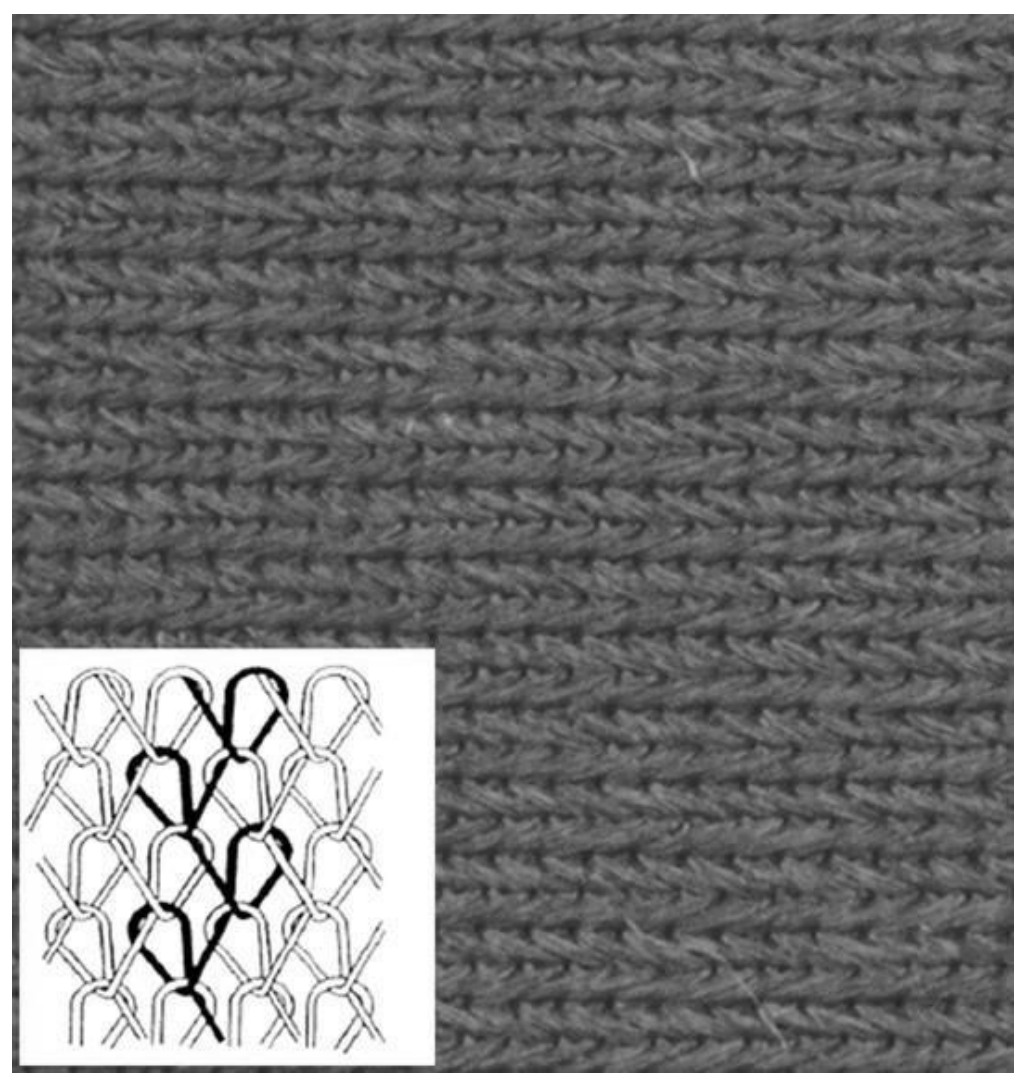

Fonte: Vasconcelos, 2015

A malha de urdidura se divide em dois tipos de máquinas principais:

- Máquinas kettenstuhl: para produção de tecidos lisos para maio, lingerie, artigos esportivos, estofamento, etc.

- Máquinas raschel: tecidos desenhados e abertos para cortinas, rendas, redes, etc.

Segundo Araujo e Castro (1986), os tecidos de malha podem ser de fabricação manual ou mecânica. No caso de fabricação manual, utilizam-se duas ou mais agulhas de tricotar ou, em alguns casos, uma só agulha

O capítulo 60 compreende os tecidos de malha planos ou tubulares, em peças ou simplesmente cortados de forma quadrada ou retangular. Todos esses tecidos podem apresentar-se tingidos, estampados ou fabricados com fios de diversas cores.

A figura 60 mostra as posições do capítulo 60. 
Figura 60 - Posições do capítulo 60

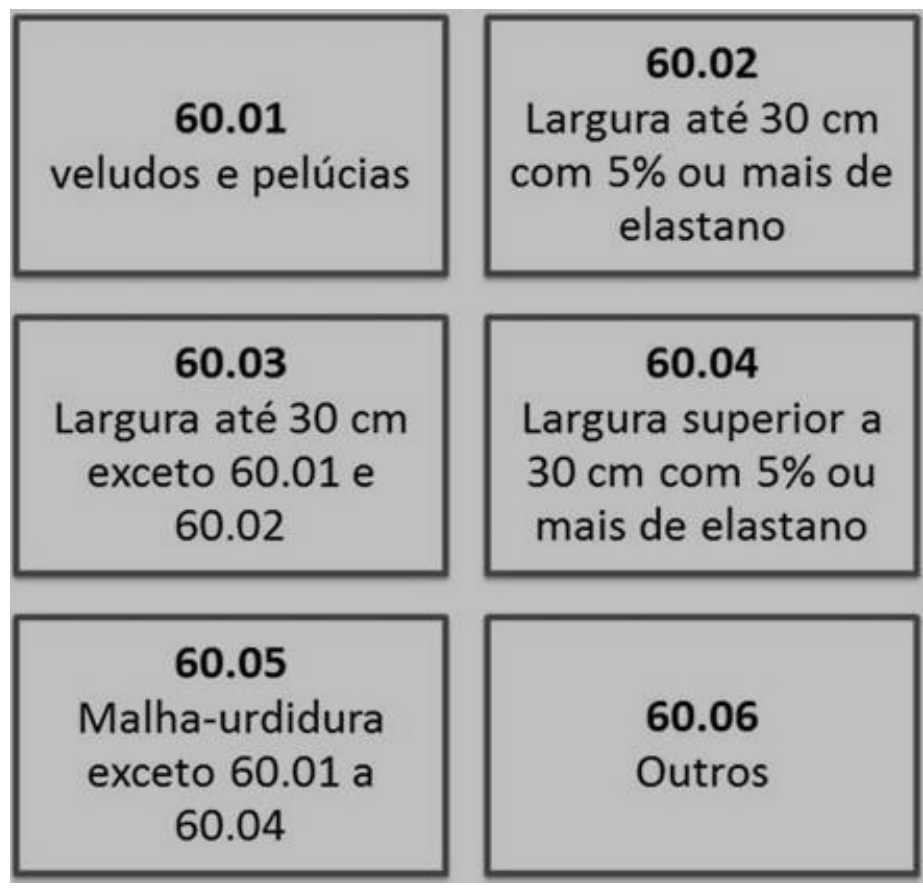

Fonte: Fabio Campos Fatalla com dados da NESH, 2016

De acordo com a NESH (2008), não se enquadram nesse capítulo:

- Os produtos obtidos por costura por entrelaçamento a partir de uma manta de fibras têxteis utilizando-se as fibras da própria manta (posição 56.02).

- As redes da posição 56.08 .

- Os tapetes de malha (posição 57.05)

- Os tecidos de malha com nós e as rendas de crochê (posição 58.04).

- Os retalhos de tecidos de malha cortados de forma quadrada ou retangular que tenham sofrido qualquer obra suplementar (debruados ou embainhados, por exemplo).

2.8.5.1 Posição 60.05 - Tecidos de malha-urdidura (incluindo os fabricados em teares para galões), exceto os das posições 60.01 a 60.04 .

Com exclusão dos veludos, pelúcias e tecidos atoalhados (posição 60.01), a presente posição compreende todos os tecidos de malha-urdidura de largura superior a $30 \mathrm{~cm}$, que não contenham nem fios de elastômeros nem fios de borracha, ou contendo menos de $5 \%$, em peso, de tais fios.

Segundo a interpretação da NESH, os tecidos de malha-urdidura obtidos em teares Raschel, imitando o aspecto de tules ou de rendas não devem ser confundidos 
com estes. São considerados como imitações de renda em malha (figura 61), muitas vezes fabricadas em peças de largura determinada, que se cortam em tiras quando dos trabalhos de acabamento. Essas tiras, de comprimento indeterminado, são classificadas nesta posição se suas bordas forem paralelas e retilíneas e que sua largura for superior a $30 \mathrm{~cm}$.

Figura 61 - Imitação de renda em malha-urdidura raschel

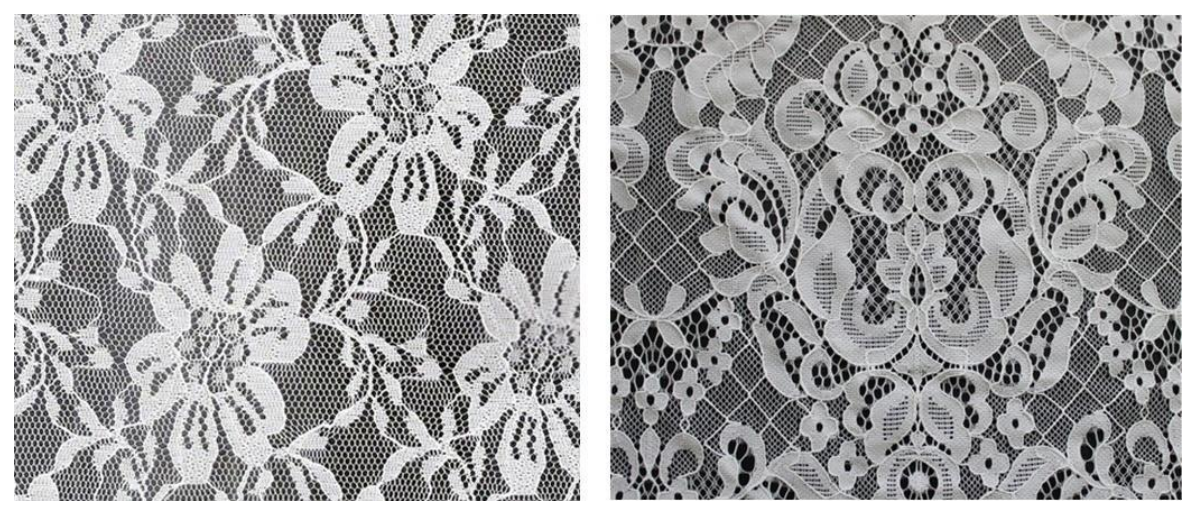

Fonte: Fabio Campos Fatalla a partir de imagens diversas, 2016

\subsubsection{Posição 60.06 - Outros tecidos de malha}

Essa posição compreende os tecidos de malha que não estejam incluídos nas posições anteriores (figura 62). Engloba especialmente os tecidos de malha-trama e os tecidos de crochê manual de largura superior a $30 \mathrm{~cm}$, que não contenham nem fios de elastômeros nem fios de borracha, ou contendo menos de $5 \%$, em peso de tais fios.

Figura 62 - Outros tecidos de malha - posição 60.06
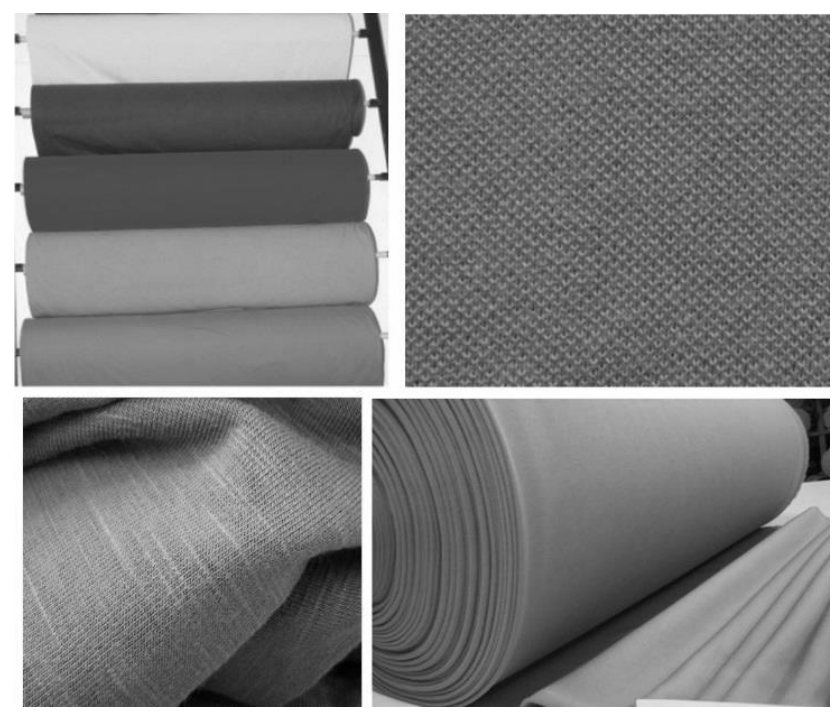

Fonte: Fabio Campos Fatalla a partir de imagens diversas, 2016 


\subsection{CLASSIFICAÇÃO DOS TÊXTEIS NOS CAPÍTULOS 61 a 63}

Os capítulos 61,62 e 63 englobam os materiais têxteis confeccionados. Para efeito de classificação, entende-se como confeccionados:

- Os artefatos cortados em forma diferente da quadrada ou retangular;

- Os artefatos obtidos já acabados e prontos para serem usados ou podendo ser utilizados depois de separados mediante simples corte dos fios não entrelaçados, sem costura nem outro trabalho complementar.

- Os artefatos cortados nas dimensões próprias em que pelo menos um lado tenha sido termosselado.

- Os artefatos cujas orlas tenham sido quer embainhadas por qualquer processo.

- Os artefatos reunidos por costura, colagem ou por qualquer outro processo.

- Os artefatos de malha obtidos em forma própria, independente de se apresentarem em unidades, ou em peças compreendendo várias unidades.

A figura 63 mostra a divisão dos capítulos 61,62 e 63 conforme o tipo de artigo:

Figura 63 - Capítulos 61, 62 e

63

\begin{tabular}{|l|l|}
\hline 61 & VESTUÁRIO E SEUS ACESSÓRIOS, DE MALHA \\
\hline 62 & VESTUÁRIO E SEUS ACESSÓRIOS, EXCETO DE MALHA \\
\hline 63 & $\begin{array}{l}\text { OUTROS ARTEFATOS TÊXTEIS CONFECCIONADOS; SORTIDOS; ARTEFATOS DE } \\
\text { MATÉRIAS TÊXTEIS, CALÇADOS, CHAPÉUS E ARTEFATOS DE USO SEMELHANTE, } \\
\text { USADOS; TRAPOS }\end{array}$ \\
\hline
\end{tabular}

Fonte: Fabio Campos Fatalla com dados da NESH, 2016

Os capítulos 61 e 62 englobam os têxteis confeccionados para vestuário e seus acessórios. Algumas definições aplicam-se aos dois capítulos:

- Vestuário masculino e feminino: De acordo com o especificado na NESH são considerados vestuários masculino e feminino:

- O vestuário que se feche na frente da esquerda para a direita é considerado vestuário de uso masculino.

- O vestuário que se feche na frente da direita para a esquerda é considerado vestuário de uso feminino. 
- O vestuário que não seja reconhecível como vestuário de uso masculino ou vestuário de uso feminino deve ser classificado como vestuário de uso feminino.

Estas disposições não se aplicam nos casos em que o corte do vestuário indique claramente que é concebido para um ou outro sexo.

- Ternos e tailleurs: Entende-se por "ternos (fatos)" e "tailleurs (fatos de saiacasaco)", os conjuntos de duas ou três peças de vestuário, confeccionados na sua face exterior, com tecido com a mesma estrutura, a mesma cor e a mesma composição, formados por:

- Um paletó (casaco) concebido para cobrir a parte superior do corpo, cuja face exterior podendo ser acompanhado de um colete cuja parte da frente seja confeccionada com o mesmo tecido que o da face exterior dos outros componentes do conjunto e cuja parte de trás seja confeccionada com o mesmo tecido que o do forro do paletó (casaco);

- Uma peça concebida para cobrir a parte inferior do corpo, podendo ser uma calça, uma bermuda (calça curta*), um short (calção) (exceto de banho), uma saia ou saia calça, sem alças nem peitilho.

O termo "ternos" abrange também os trajes de cerimônia ou de noite como o fraque, a casaca e o smoking, mesmo que não sejam satisfeitas todas as condições precedentes.

\subsubsection{Capítulo 61 - vestuário e seus acessórios, de malha}

Esse capítulo compreende os artefatos confeccionados apenas de malha. Inclui o vestuário e seus acessórios, ou seja, os artefatos de uso masculino ou feminino e os acessórios que sirvam para guarnece-los ou completa-los. Também se incluem neste Capítulo as partes de malha, de vestuário ou de seus acessórios. No entanto, não inclui os sutiãs, cintas, espartilhos, suspensórios, ligas e artefatos semelhantes, mesmo que produzidos em malha os quais são incluídos na posição 62.12 .

Os artigos incluídos neste capítulo podem conter partes e acessórios de tecido, plástico, couro, peleteria (peles com pelo), metal, penas, etc.

O vestuário que tenha na parte frontal uma abertura cujas duas partes se fechem da esquerda para a direita é considerado como vestuário de uso masculino enquanto 
aqueles na qual a abertura se fecha da direita para esquerda é considerado como de uso feminino, com exceção dos casos em que o corte do vestuário indique claramente que é concebido para um ou outro sexo. O vestuário que não seja reconhecível como vestuário de uso masculino nem vestuário de uso feminino deve ser classificado como vestuário de uso feminino.

As posições desse Capítulo estão mostradas na figura 64 .

Figura 64 - Posições do capítulo 61

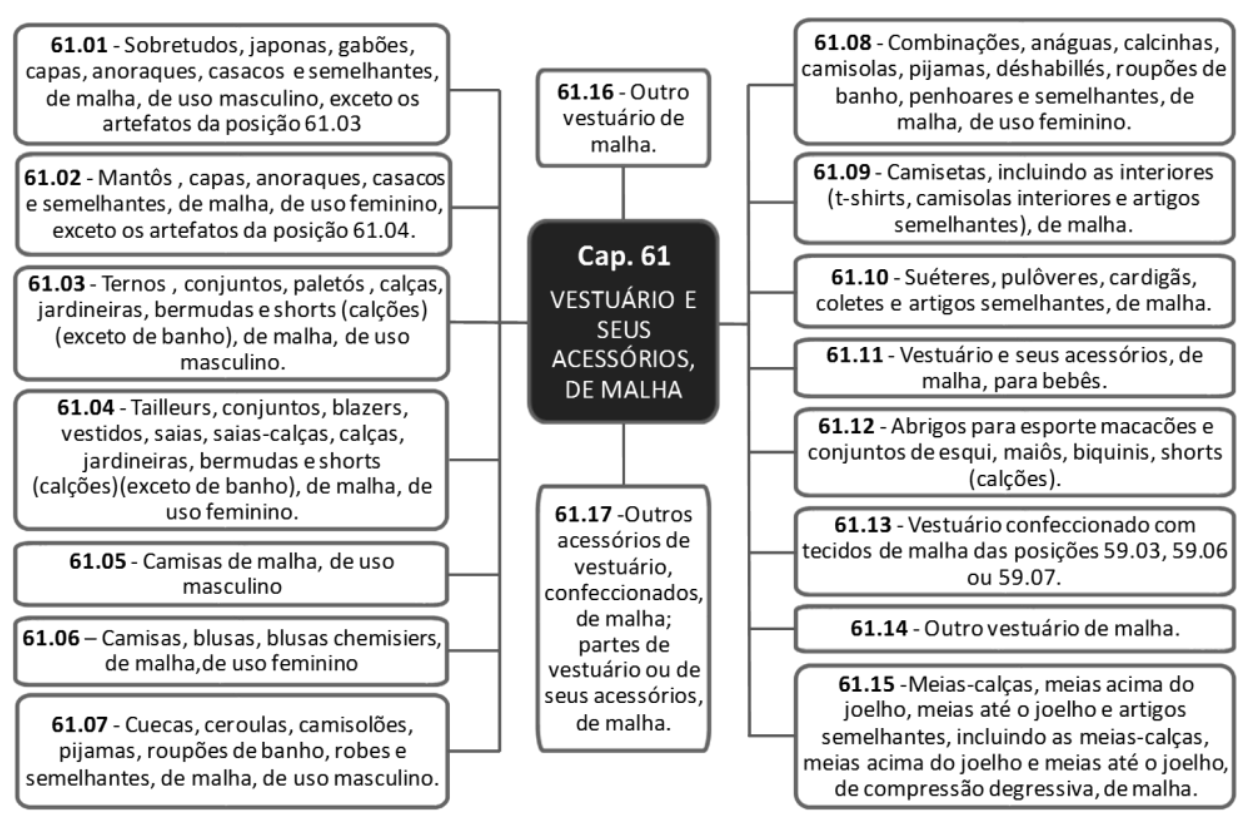

Fonte: Fabio Campos Fatalla com dados da NESH, 2016

\subsubsection{Capítulo 62 - vestuário e seus acessórios exceto malha}

O capítulo 62 compreende:

- Artigos confeccionados com qualquer tecido dos capítulos 50 a 55, 58 e 59

- Artigos confeccionados de feltro ou de "falsos tecidos".

- Abrange também, excepcionalmente, na posição 62.12, certos artefatos de malha.

As posições desse capítulo estão mostradas na figura 65. 
Figura 65 - Posições do capítulo 62

\begin{tabular}{|c|c|c|}
\hline $\begin{array}{c}\text { 62.01 -Sobretudos, japonas, gabões, } \\
\text { capas, anoraques, casacos e semelhantes, } \\
\text { de uso masculino, exceto os artefatos da } \\
\text { posição } 62.03 \text {. }\end{array}$ & $\begin{array}{l}\mathbf{6 2 . 1 6} \text { - Luvas, } \\
\text { mitenes e } \\
\text { semelhantes. }\end{array}$ & $\begin{array}{l}\text { 62.08 - Corpetes, combinações, anáguas, } \\
\text { calcinhas, camisolas, pijamas, déshabillés, } \\
\text { roupões de banho, penhoares e } \\
\text { semelhantes, de uso feminino. }\end{array}$ \\
\hline $\begin{array}{l}\text { 62.02 - Mantôs, capas, anoraques, casacos } \\
\text { e semelhantes, de uso feminino, exceto os }\end{array}$ & \multirow{3}{*}{$\begin{array}{c}\text { Cap. } 62 \\
\text { VESTUÁRIO E } \\
\text { SEUS } \\
\text { ACESSÓRIOS, } \\
\text { EXCETO DE } \\
\text { MALHA }\end{array}$} & $\begin{array}{c}\text { 62.09-Vestuário e seus acessórios, para } \\
\text { bebês. }\end{array}$ \\
\hline $\begin{array}{l}\text { 62.03 - Ternos, conjuntos, paletós, calças, } \\
\text { jardineiras, bermudas e shorts (calções) } \\
\text { (exceto de banho), de uso masculino. }\end{array}$ & & $\begin{array}{c}\mathbf{6 2 . 1 0} \text { - Vestuário confeccionado com as } \\
\text { matérias das posições } 56.02,56.03,59.03 \text {, } \\
59.06 \text { ou } 59.07 . .\end{array}$ \\
\hline (exceto de banho), de uso masculino. & & $\begin{array}{c}\text { 62.11 - Abrigos para esporte macacões e } \\
\text { conjuntos de esqui, maiôs, biquinis, shorts } \\
\text { (calções) e sungas de banho. }\end{array}$ \\
\hline $\begin{array}{c}\text { vestidos, saias, saias-calças, calças, } \\
\text { jardineiras, bermudas e shorts } \\
\text { (calções)(exceto de banho), de uso } \\
\text { feminino. }\end{array}$ & 62.17-Outros & $\begin{array}{c}\text { 62.12 - Sutiãs, cintas, espartilhos, } \\
\text { suspensórios, ligas e artefatos } \\
\text { semelhantes, e suas partes, mesmo de } \\
\text { malha }\end{array}$ \\
\hline 62.05 - Camisas de uso masculino & $\begin{array}{l}\text { confeccionados } \\
\text { de vestuário; }\end{array}$ & 62.13 -Lenços de assoar e de bolso. \\
\hline $\begin{array}{l}\text { 62.06 - Camisas, blusas, blusas chemisiers, } \\
\text { de uso feminino }\end{array}$ & $\begin{array}{l}\text { partes de } \\
\text { vestuário ou } \\
\text { dos seus } \\
\text { acessórios, }\end{array}$ & $\begin{array}{c}\text { 62.14 -Xales, echarpes, lenços de pescoço, } \\
\text { cachenês, cachecóis, mantilhas, véus e } \\
\text { artefatos semelhantes. }\end{array}$ \\
\hline $\begin{array}{l}\text { 62.07 - Cuecas, ceroulas, camisolões, } \\
\text { pijamas, roupões de banho, robes e } \\
\text { semelhantes, de uso masculino. }\end{array}$ & $\begin{array}{c}\text { exceto as da } \\
\text { posição } 62.12 .\end{array}$ & $\begin{array}{l}\text { 62.15 - Gravatas, gravatas-borboletas e } \\
\text { plastrons. }\end{array}$ \\
\hline
\end{tabular}

Fonte: Fabio Campos Fatalla com dados da NESH, 2016

\subsubsection{Capítulo 63 - Outros Artefatos Têxteis Confeccionados; Sortidos; Artefatos de Matérias Têxteis, Calçados, Chapéus e Artefatos de uso semelhante, usados; Trapos}

Esse capítulo compreende outros artefatos confeccionados que não se enquadram nos capítulos 61 e 62 . As posições desse capítulo estão mostradas na figura 66.

Figura 66 - Posições do capítulo 63

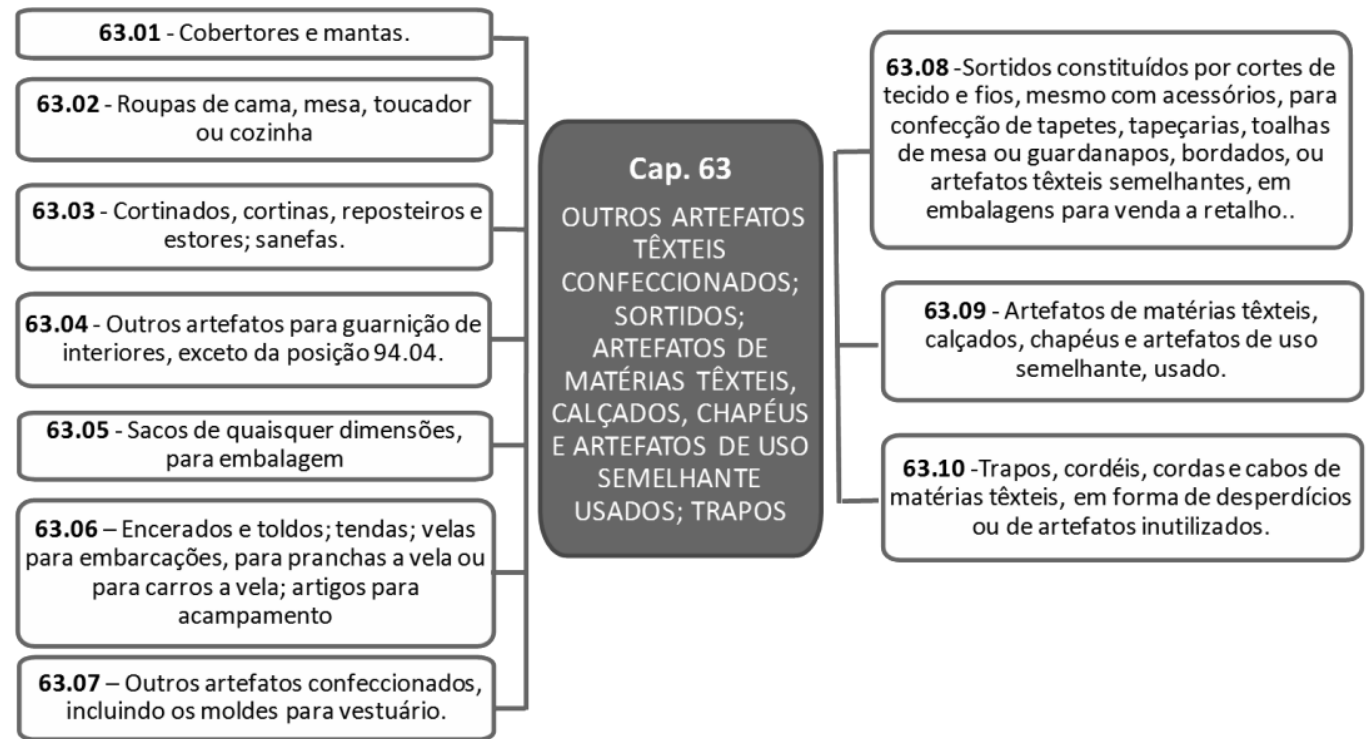

Fonte: Fabio Campos Fatalla com dados da NESH, 2016 


\subsection{ATO DECLARATÓRIO EXECUTIVO (ADE) COANA 22}

O ADE COANA 22 (2005) é um ato declaratório que dispõe sobre a descrição de fios e tecidos classificados nos capítulos 50 a 60 da Nomenclatura Comum do Mercosul.

Ele define as informações que deverão constar na descrição detalhada de fios e tecidos e contém os parâmetros necessários para a classificação do material sendo fundamental para sua correta realização. Essas informações são:

\subsubsection{Informações restritas aos fios:}

I - Quanto à natureza da matéria-

prima 1 - Natural

1.1 - Vegetais

1.1.1 - Algodão

1.1.2 - Linho

1.1.3 - Rami

1.1.4 - Juta

1.1.5 - Outras (especificar)

1.2 - Animais

1.2.1 - Lã

1.2.2 - Seda

1.2.3 - Outras (especificar)

2 - Química

2.1 - Artificiais

2.1.1 - Raiom viscose

2.1.2 - Acetato

2.1.3 - Modal

2.1.4 - Lyocel

2.1.5 - Cupro

2.1.6 - Outras (especificar)

2.2 - Sintéticas

2.2.1 - Poliéster

2.2.2 - Poliamida

2.2.3 - Acrílico 
2.2.4 - Elastano

2.2.5 - Polipropileno

2.2.6 - Outras (especificar) 3 -

Composição

Especificar a composição percentual do fio, mencionando a \% em peso, de cada um dos seus constituintes, segundo a natureza da matéria-prima (subitens 1 e 2 anteriores).

II - Quanto ao processo de fabricação 1 -

Fio de fibra descontínua

1.1 - Fio cardado

1.1.1 - Ring

1.1.2 - Open-End

1.2 - Fio penteado

1.3 - Outros (especificar)

2 - Fio monofilamento ou multifilamento contínuo

2.1 - Fio parcialmente orientado

2.2 - Fio texturizado

2.3 - Fio liso

2.4 - Fio elastomérico

2.5 - Fio de alta tenacidade

2.6 - Outros (especificar) III -

Quanto à torção

1 - Fio simples (singelo)

2 - Fio retorcido ou retorcido múltiplo IV

- Quanto ao beneficiamento

1 - Fio cru 2 -

Fio tinto

3 - Fio branqueado 4 -

Fio fantasia

5 - Outros (especificar)

V - Quanto à forma de acondicionamento 1 -

Bobina

2 - Cone 
3 - Cops

4 - Outras (especificar)

IV - Quanto a outras informações

1 - Título (em dTex)

2 - Tenacidade (se aplicável) (em cN/Tex)

3 - Número de torções (voltas/metro)

\subsubsection{Informações restritas aos tecidos:}

I - Quanto à estrutura do

tecido 1 - Tecido

plano

2 - Tecido de malha

2.1 Malha de trama

2.1.1 - Circular

2.1.2 - Retilínea

2.2 Malha de

urdume 3 - Tecido

felpudo

4 - Falso tecido

5 - Tecidos especiais (veludos, pelúcia, chenille, tufados, rendas, tapeçarias, passamanarias e bordados)

6 - Outros (especificar)

II - Quanto à natureza da matéria-

prima 1 - Natural

1.1 - Vegetais

1.1.1 - Algodão

1.1.2 - Linho

1.1.3 - Rami

1.1 .4 - Juta

1.1.5 - Outras (especificar)

1.2 - Animais

1.2.1 - Lã

1.2.2 - Seda 


\subsection{3 - Outras (especificar)}

2 - Química

2.1 - Artificiais

2.1.1 - Raiom viscose

2.1.2 - Acetato

2.1.3 - Modal

2.1.4 - Liocel

2.1.5 - Cupro

2.1.6 - Outras (especificar)

2.2 - Sintéticas

2.2.1 - Poliéster

2.2.2 - Poliamida

2.2.3 - Acrílico

2.2.4 - Elastano

2.2.5 - Polipropileno

2.2.6 - Outras (especificar) 3 -

Composição

Especificar a composição percentual do tecido, mencionando a \% em peso, de cada um dos seus constituintes, segundo a natureza da matéria-prima (subitens 1 e 2 anteriores).

III - Quanto ao tipo de ligamento dos fios 1 -

Tela

2 - Sarja

3 - Cetim

4 - Outros (especificar) IV -

Quanto ao beneficiamento

1 - Tecido cru 2 -

Tecido tinto

3 - Tecido branqueado

4 - Tecido de fios de diversas cores 5 -

Tecido estampado

6 - Outros (especificar)

IV - Quanto a outras informações 1 - 
Título dos fios (em Dtex) 2 -

Largura do tecido

3 - Gramatura do tecido (g/m2) 


\section{MATERIAIS E MÉTODOS}

Para esse estudo a metodologia proposta para a classificação de mercadorias têxteis na NCM consiste em 4 passos:

$1^{\circ}$ passo:

Desvendar a mercadoria a ser classificada, identificando:

- No que consiste a mercadoria;

- Qual sua função principal;

- Material constitutivo (\%);

- Aplicação, uso ou emprego;

- Nome comercial, técnico, científico, vulgar, marca registrada...

- Forma ou apresentação;

- Se possui acessórios, opcionais, etc.

$2^{\circ}$ passo:

Aplicar as regras de Interpretação do Sistema Harmonizado:

- Lembrando que as regras devem ser aplicadas na ordem sequencial, sendo que só se deve passar para a próxima regra, se não for possível a classificação pela regra presente.

- Como a classificação se dá, pelo texto da posição e notas de seção e capítulo, é IMPRESCINDÍVEL ler todas as notas de seção e capítulos, antes de iniciar a classificação.

- Sempre que não for possível classificar pela aplicação das Regras, recorrer às Normas Explicativas do Sistema Harmonizado (NESH).

$3^{\circ}$ passo:

Enquadrar sistematicamente a mercadoria na seção, capítulo, posição, subposição de primeiro e segundo nível, item e subitem. Sempre nessa sequência. 
Verificar os pontos chaves de diferenciação contidos na descrição dos capítulos, posições, subposições, itens e subitens da NCM (figura 67).

Figura 67 - Capítulos 50 a 55

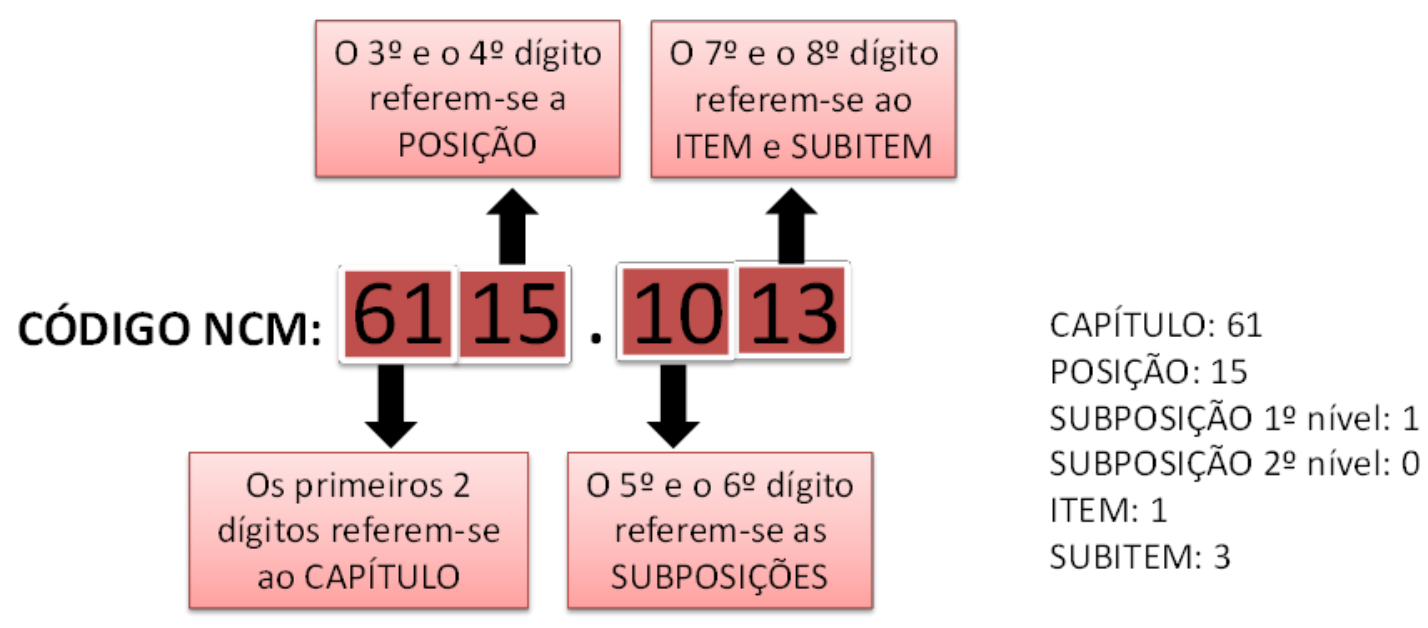

Fonte: Fabio Campos Fatalla, 2016

- Construir um fluxograma lógico de decisão baseado nos pontos chaves levantados e nas regras de classificação.

- Analisar e descrever os produtos a serem classificados de acordo com a ADE COANA 22, focando especialmente esses pontos chaves.

- Submeter o material ao fluxo de decisão e determinar sua classificação.

$4^{\circ}$ passo:

Por fim, após determinar a classificação da mercadoria, tão importante quanto a classificação é a descrição da mercadoria de forma a evidenciar a classificação fiscal adotada.

Dada a grande quantidade de classificações foram escolhidos alguns produtos típicos para exemplificar a aplicação da metodologia proposta. Esses produtos são:

- Fio $100 \%$ algodão

- Tecido plano algodão/poliéster/viscose

- Tecido de malha por urdume poliamida/elastano

- Vestido de tecido plano algodão

Dessa forma foram construídos fluxos de decisão com foco nos 
produtos utilizados como exemplo.

\subsection{DISTINÇÃO ENTRE OS CAPÍTULOS 50 A 55 E 56 A 63}

Existe uma distinção de enfoque entre os capítulos 50 a 55 e 56 a 63 . Nos capítulos 50 a 55 os produtos têxteis são agrupados conforme as matérias que os constituem (figura 68). Cada um deles trata de uma ou de várias matérias têxteis, puras ou misturadas entre si, nas diferentes fases de manufatura até a sua transformação em tecidos.

Compreende principalmente:

- Fibras

- Resíduos de fibras

- Fios

- Tecidos planos comuns

Figura 68 - Capítulos 50 a 55

\begin{tabular}{|l|l|}
\hline $\mathbf{5 0}$ & SEDA \\
\hline $\mathbf{5 1}$ & LÃ, PELOS FINOS OU GROSSEIROS; FIOS E TECIDOS DE CRINA \\
\hline $\mathbf{5 2}$ & ALGODÃO \\
\hline $\mathbf{5 3}$ & OUTRAS FIBRAS TÊXTEIS VEGETAIS; FIOS DE PAPEL E TECIDOS DE FIOS DE PAPEL \\
\hline $\mathbf{5 4}$ & $\begin{array}{l}\text { FILAMENTOS SINTÉTICOS OU ARTIFICIAIS; LÂMINAS E FORMAS SEMELHANTES DE } \\
\text { MATERIAS TÊXTEIS SINTÉTICAS OU ARTIFICIAIS }\end{array}$ \\
\hline $\mathbf{5 5}$ & FIBRAS SINTÉTICAS OU ARTIFICIAIS, DESCONTÍNUAS \\
\hline
\end{tabular}

Fonte: Fabio Campos Fatalla com base na NESH, 2016

Por outro lado, os capítulos 56 a 63 englobam os materiais têxteis conforme o tipo de produto/aplicação, com destaque para os tecidos de malha e os produtos confeccionados, além de feltros, não tecidos, tapetes, rendas, tecidos impregnados, etc., de acordo com o especificado na figura 69. 
Figura 69 - Capítulos 56 a 63

\begin{tabular}{|l|l|}
\hline 56 & $\begin{array}{l}\text { PASTAS (OUATES), FELTROS E FALSOS TECIDOS; FIOS ESPECIAIS; CORDÉIS, CORDAS } \\
\text { E CABOS; ARTIGOS DE CORDOARIA }\end{array}$ \\
\hline 57 & $\begin{array}{l}\text { TAPETES E OUTROS REVESTIMENTOS PARA PISOS (PAVIMENTOS), DE MATÉRIAS } \\
\text { TÊXTEIS }\end{array}$ \\
\hline 58 & $\begin{array}{l}\text { TECIDOS ESPECIAIS; TECIDOS TUFADOS; RENDAS; TAPEÇARIAS; PASSAMANARIAS; } \\
\text { BORDADOS }\end{array}$ \\
\hline 59 & $\begin{array}{l}\text { TECIDOS IMPREGNADOS, REVESTIDOS, RECOBERTOS OU ESTRATIFICADOS; } \\
\text { ARTIGOS PARA USOS TÉCNICOS DE MATÉRIAS TÊXTEIS }\end{array}$ \\
\hline 60 & TECIDOS DE MALHA \\
\hline 61 & VESTUÁRIOE SEUS ACESSÓRIOS, DE MALHA \\
\hline 63 & $\begin{array}{l}\text { VESTUÁRIOE SEUS ACESSÓRIOS, EXCETO DE MALHA } \\
\text { MATÉRIAS TÉXTEIS, CALÇADOS, CHAPÉUS E ARTEFATOS DE USO SEMELHANTE, } \\
\text { USADOS; TRAPOS }\end{array}$ \\
\hline
\end{tabular}

Fonte: Fabio Campos Fatalla com base na NESH, 2016

Dessa forma um primeiro ponto chave de diferenciação consiste em verificar se o material é composto de fibras, resíduos de fibras, fios ou tecidos planos (capítulos 50 a 55) ou não (capítulos 56 a 63), conforme mostrado na figura 70.

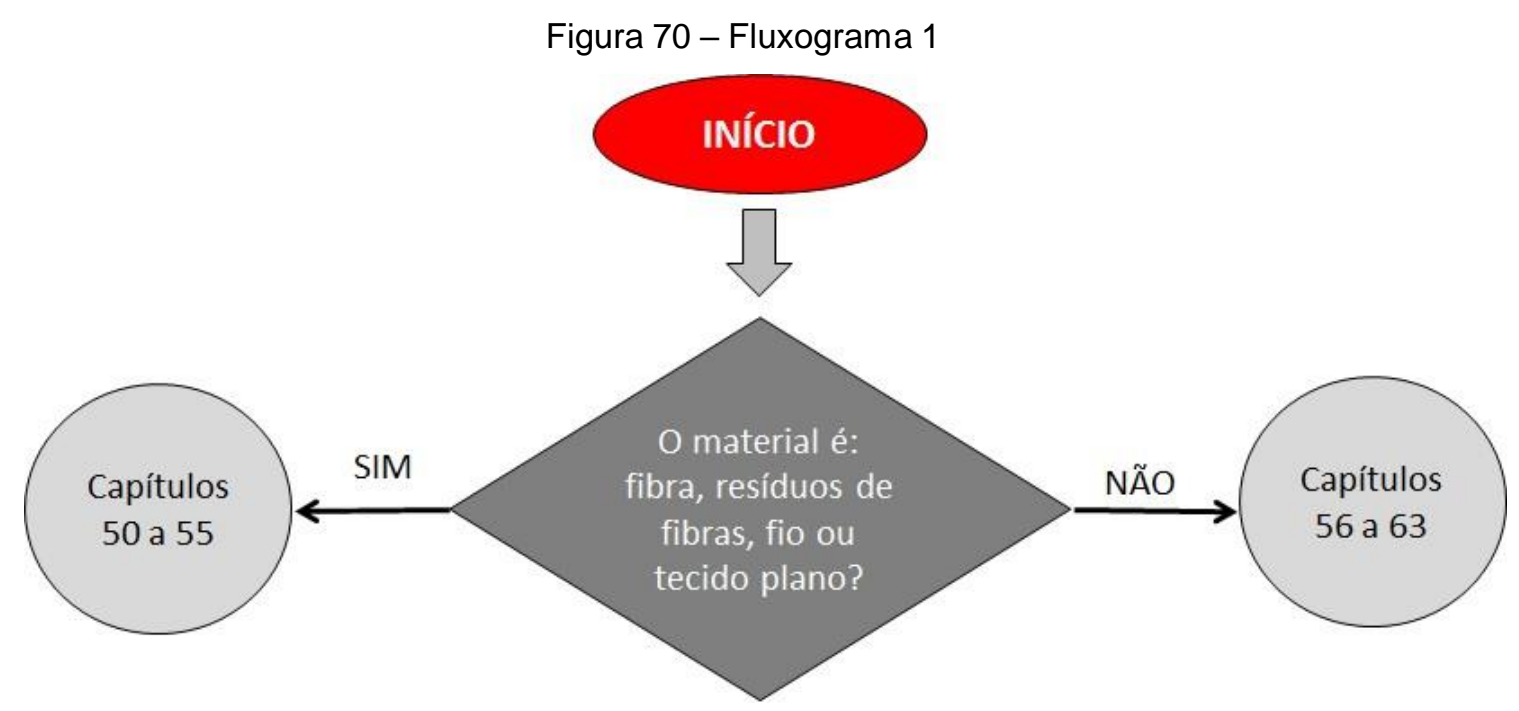

Fonte: Fabio Campos Fatalla, 2016 


\subsection{CAPÍTULOS 50 A 55}

Conforme já mostrado na figura 68, os capítulos 50 a 55 são divididos função do tipo de fibra. Assim o novo ponto chave de diferenciação é o tipo de fibra. Pode ser feita uma primeira distinção entre naturais e artificiais / sintéticas. Entre as fibras naturais, deve-se separa-las em animais (seda - 50 e lã - 51) e vegetais (algodão - 52 e outras vegetais - 53). Entre as artificiais / sintéticas a separação é entre filamentos

(54) e fibras descontinuas (55). Essa análise está mostrada no fluxograma da figura 71.

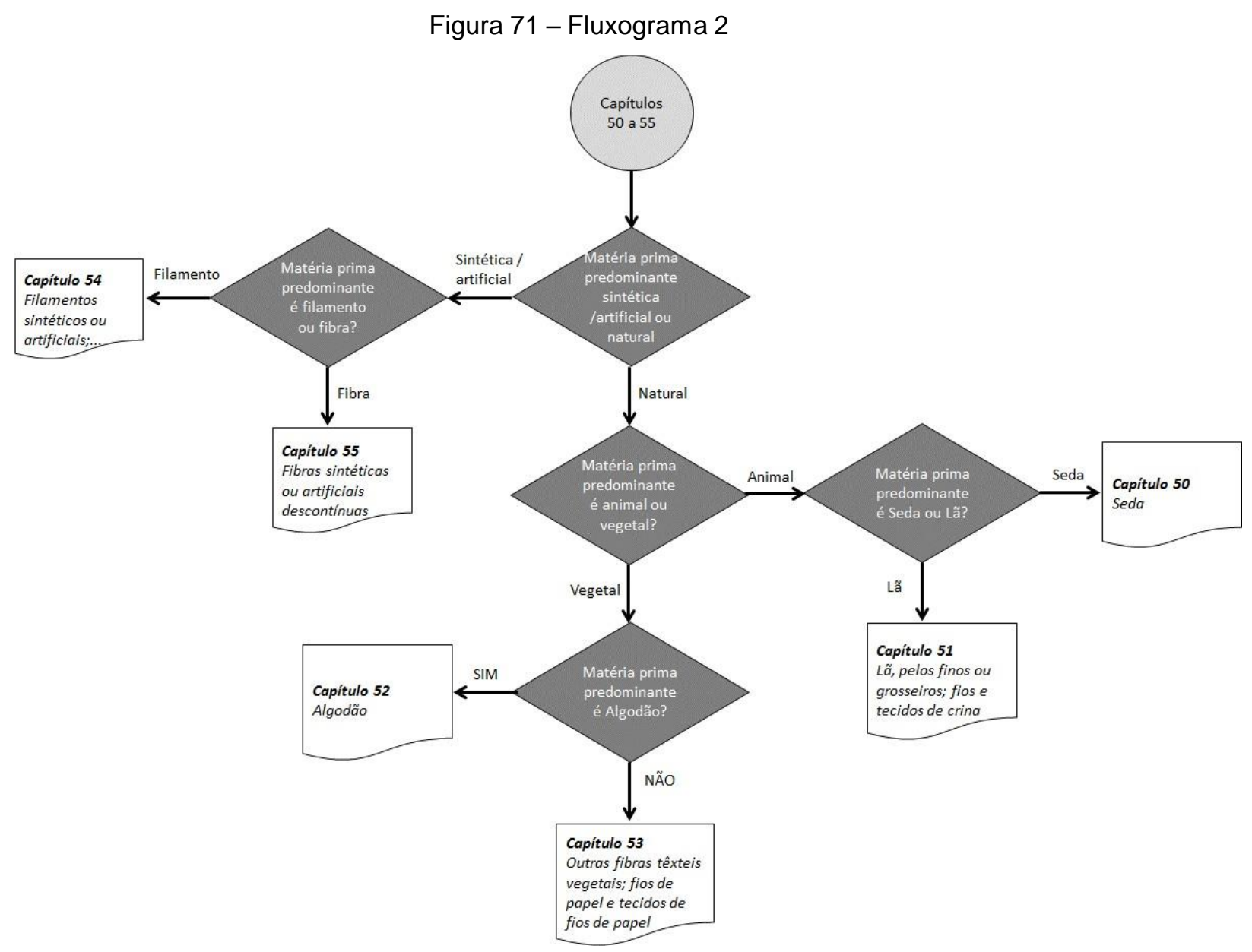

Fonte: Fabio Campos Fatalla, 2016

\subsubsection{Fios de algodão}

Os artigos de algodão do capítulo 52 são divididos nas posições mostradas na figura 72. 
Analisando as posições é possível verificar um primeiro ponto chave de diferenciação ou seja o tipo de material têxtil:

- Fibras

- Fios

- Tecidos

Essa interpretação está mostrada no fluxo da figura 73.

Figura 72 - Posições do capitulo 52
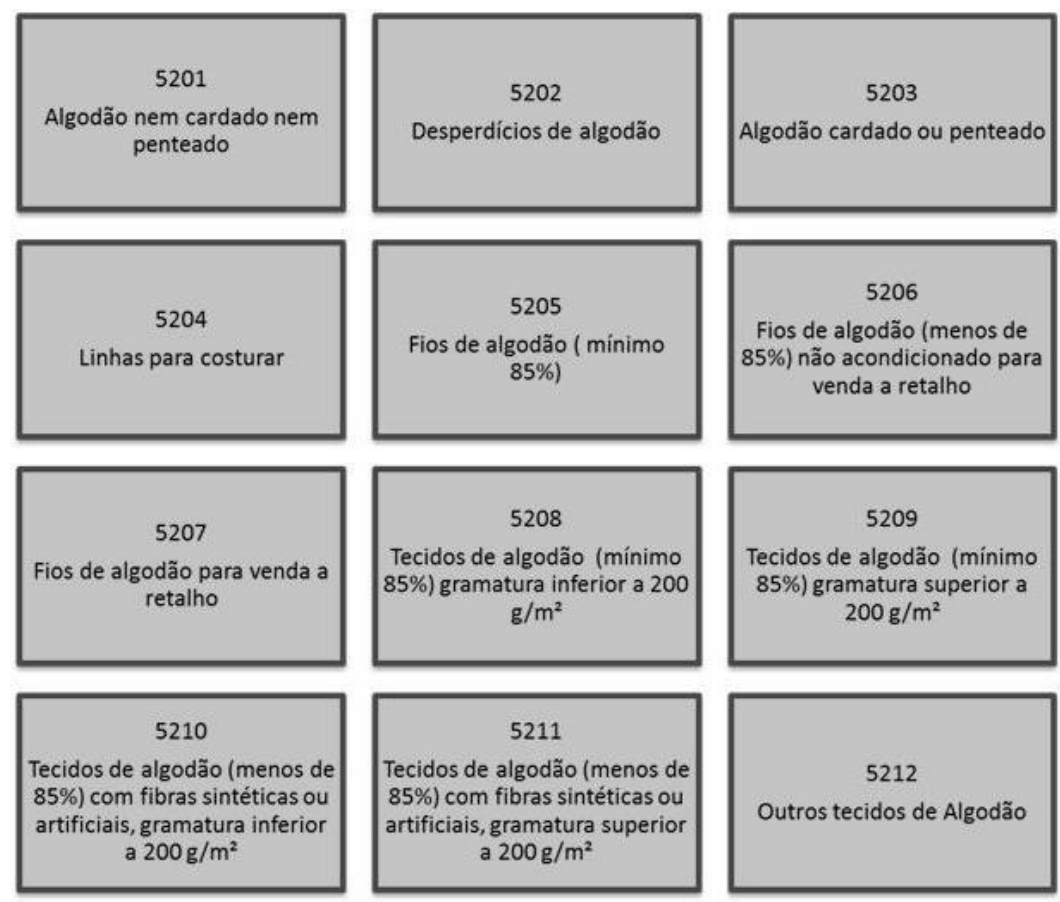

Fonte: Fabio Campos Fatalla com base na NESH, 2016

Figura 73 - Fluxograma de posições do capitulo 52 (1)

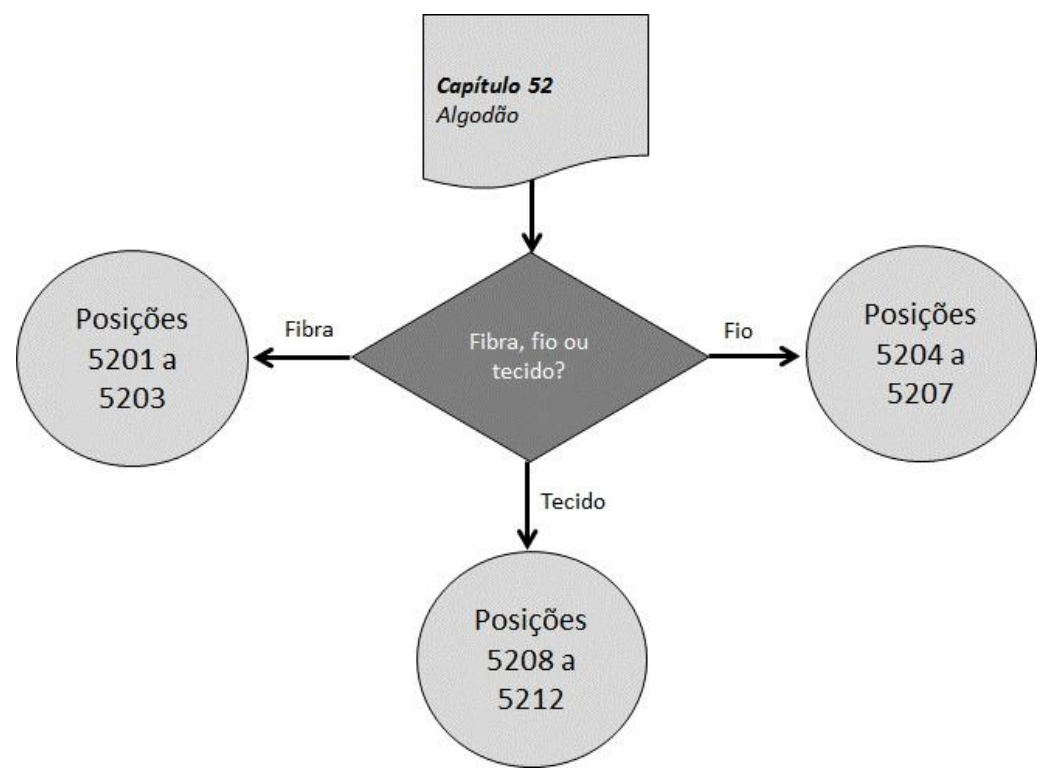

Fonte: Fabio Campos Fatalla, 2016 
No caso dos fios de algodão, o próximo grupo de pontos chaves inclui:

- Linhas para costura

- Fios de algodão

- mínimo $85 \%$ de algodão

- menos de $85 \%$ de algodão

- Fios de algodão acondicionado para venda a retalho

A figura 63 mostra esses pontos chaves incluídos no fluxograma.

Figura 74 - Fluxograma de posições para fios de algodão (2)

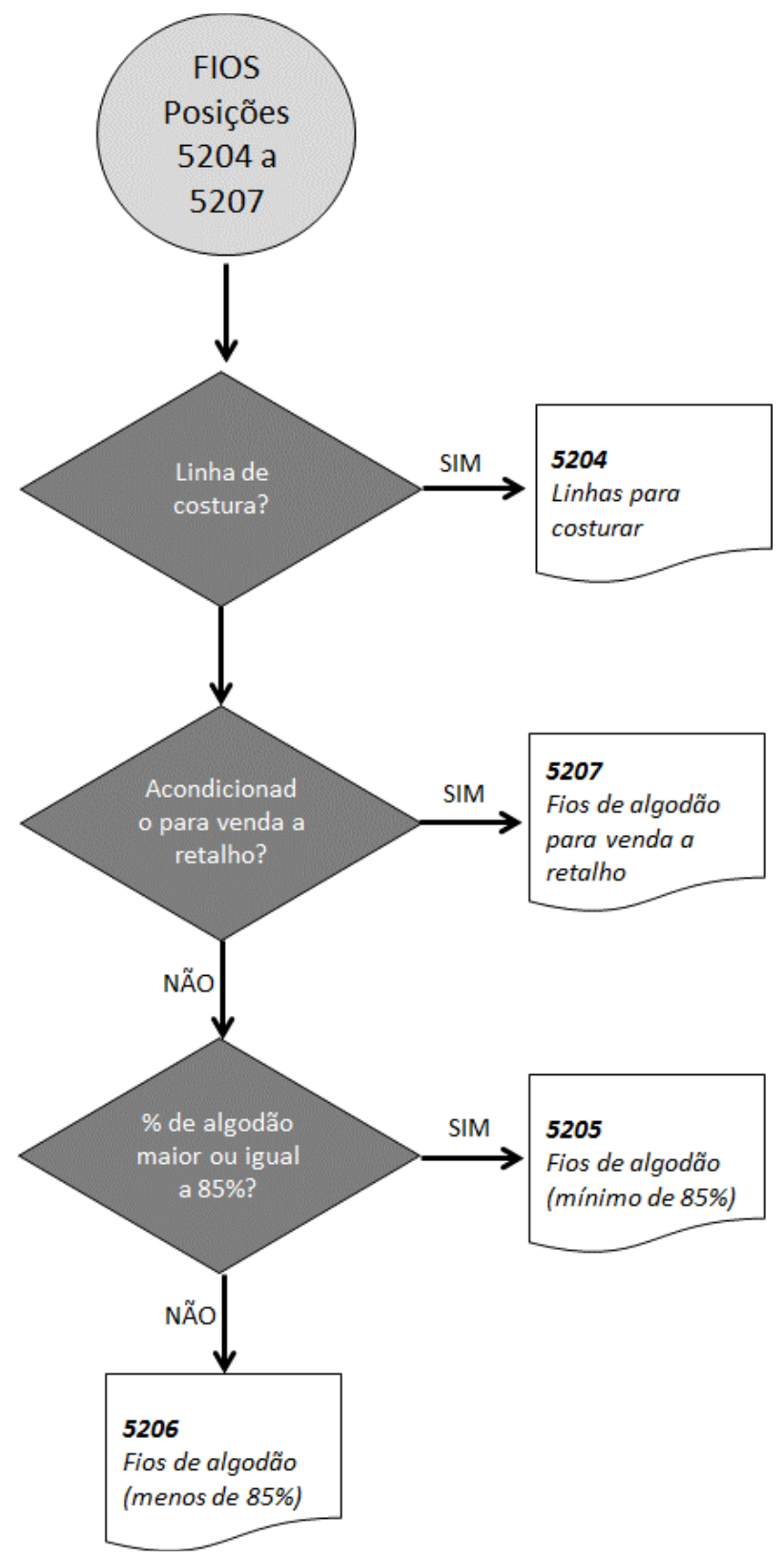

Fonte: Fabio Campos Fatalla, 2016 
3.2.1.1 Subposições para fios com mínimo de $85 \%$ de algodão

A posição 5205, considera dois níveis de pontos chaves na definição das subposições. O primeiro nível leva em conta o número de cabos (simples ou retorcido) e o tipo de processo cardado (não penteado) ou penteado:

- Fios simples

- Fibras não penteadas

- Fibras penteadas

- Fios retorcidos

- Fibras não penteadas

- Fibras penteadas

Esses pontos estão abordados no fluxograma da figura 75

Figura 75 - Fluxograma de subposições para fios de algodão nível 1

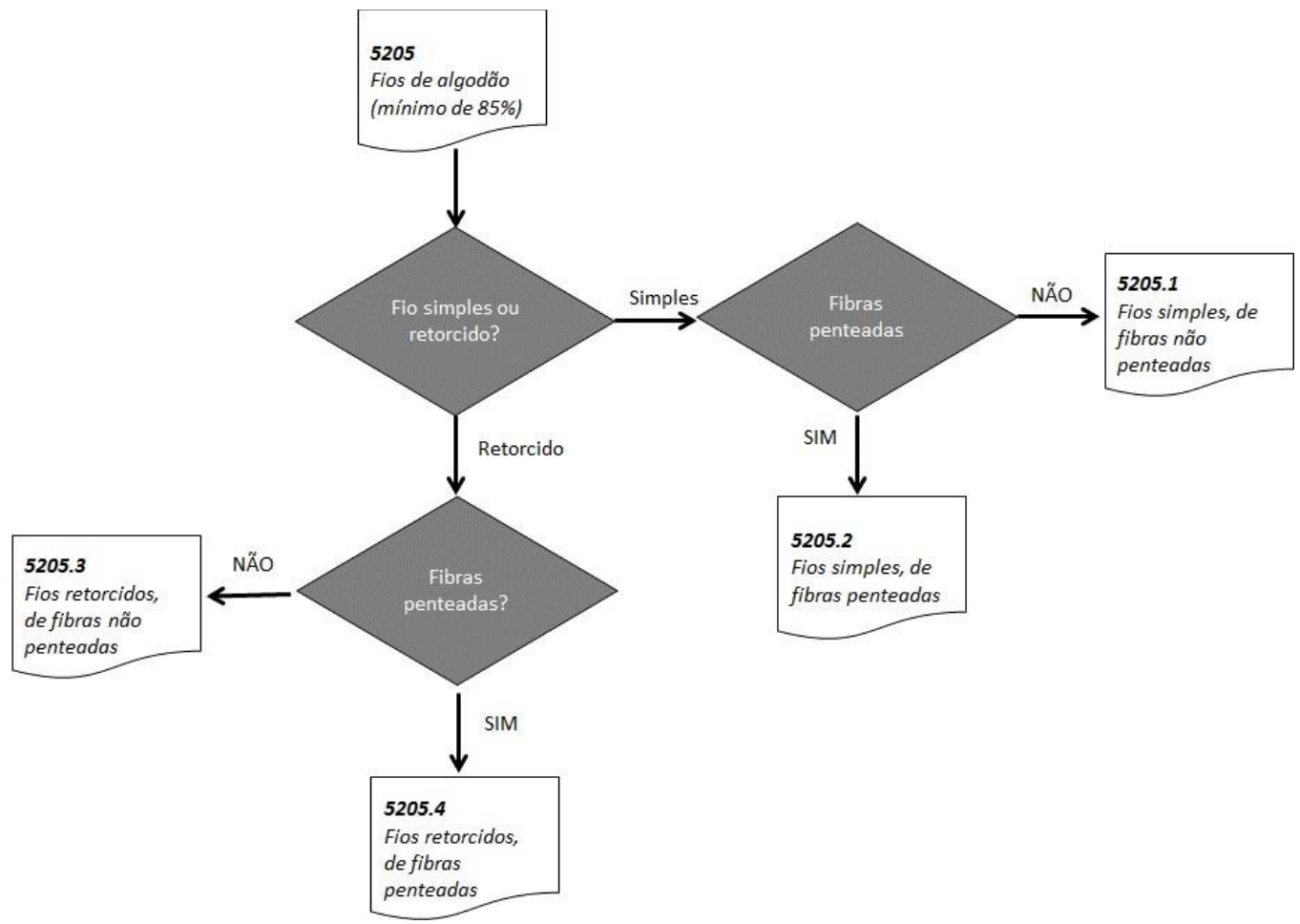

Fonte: Fabio Campos Fatalla, 2016

O segundo nível de subposição refere-se ao título do fio. No caso de fio de algodão retorcido não penteado as classificações são (figura 64):

- De título igual ou superior a 714,29 decitex por fio simples

- De título inferior a 714,29 decitex mas não inferior a 232,56 decitex, por fio 
simples

- De título inferior a 232,56 decitex mas não inferior a 192,31 decitex, por fio simples

- De título inferior a 192,31 decitex mas não inferior a 125 decitex, por fio simples

- De título inferior a 125 decitex por fio simples

Como essa classificação específica não possui itens ou subitens, todos apresentam final 00 .

Figura 76 - Fluxograma de subposições para fios de algodão nível 2

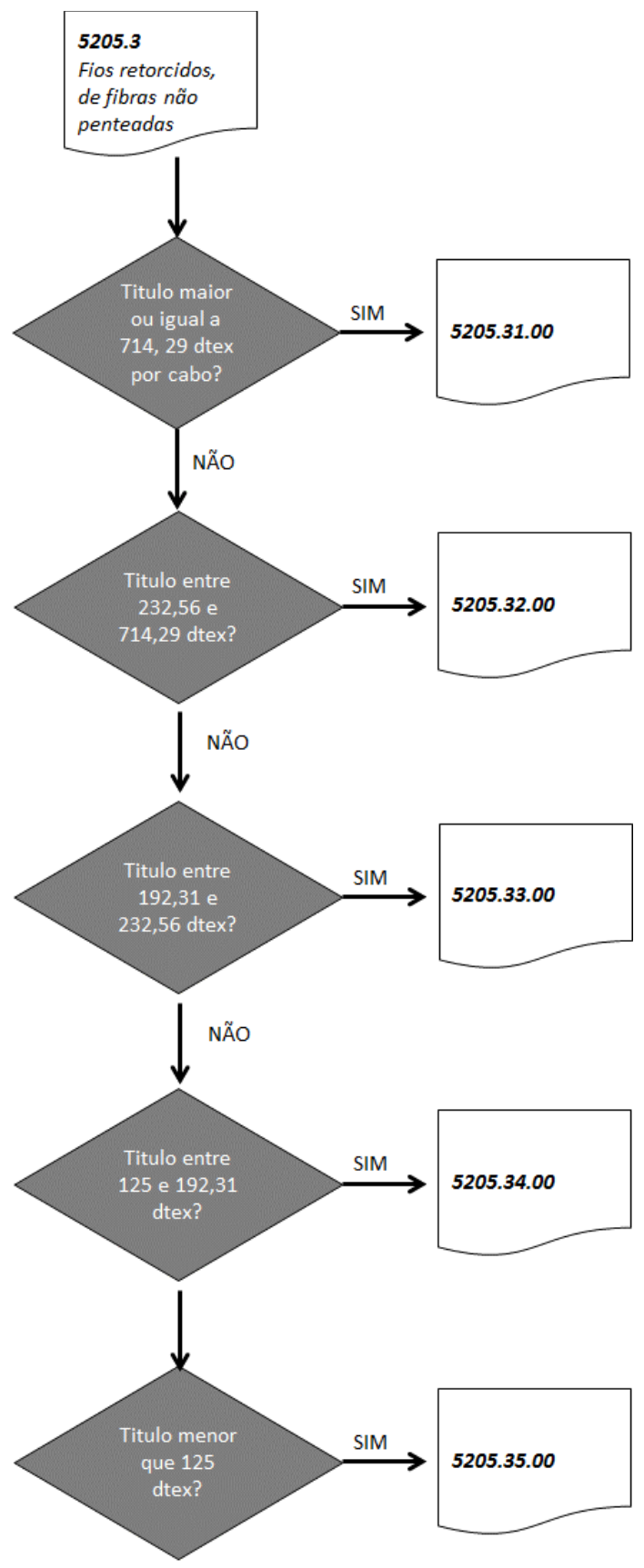

Fonte: Fabio Campos Fatalla 
3.2.1.2 Pontos chaves para fios de algodão - resumo:

- Tipo de acondicionamento (linha de costura, venda a retalho ou fio normal)

- Porcentagem de algodão

- Número de cabos (simples ou retorcido)

- Processo fiação (penteado ou não)

- Titulo do fio

\subsubsection{Tecido de fibras sintéticas descontinuas tinto}

Nesse caso trata-se de um tecido com predominância de fibras sintéticas, que reporta ao capitulo 55 cujas posições estão mostradas na figura 77 .

Figura 77 - Posições do capitulo 55

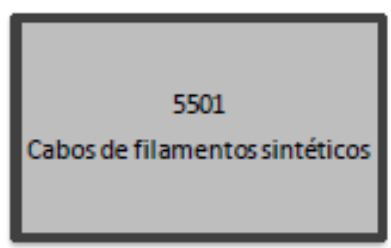

5505

Desperdícios defibras sintéticas ou artificiais

5509

Fios de fibras sintéticas descontínuasnão acondicionados paravenda a retalho

\section{3}

Tecidos de fibras sintéticas descontínuas com menos de $85 \%$ combinados com algodão com gramatura inferior a 170 $\mathrm{g} / \mathrm{m}^{2}$
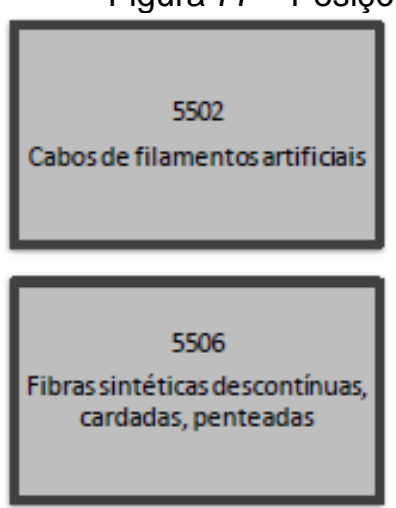

5510

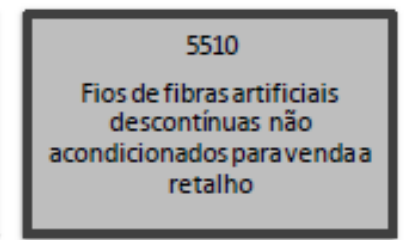

\section{4}

Tecidos de fibras sintéticas descontínuas com menos de $85 \%$ combinados comalgodão com gramatura superior a 170 $\mathrm{g} / \mathrm{m}^{2}$
5503

Fibras sintéticas descontínuas,

não cardadas, não penteadas

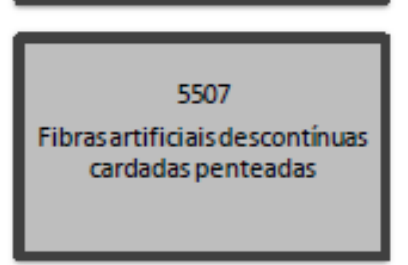

5511

Fios de fibras sintéticas ou

artificiais descontínuos

acondicionados paravendaa

retalho

5515

Outros tecidos de fibras

sintéticas descontínuas

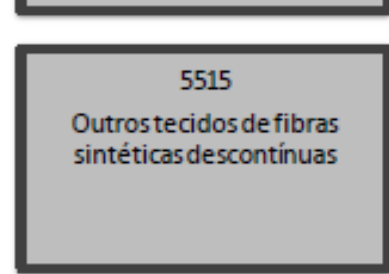

5504

Fibras artificiais descontinuas,

não cardadas, não penteadas

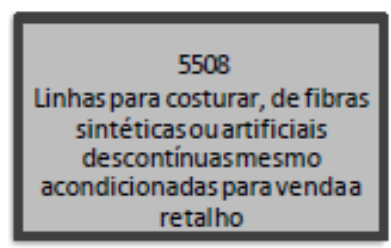

5512

Tecidos de fibras sintéticas

descontínuas que tenham pelo menos $85 \%$ dessas fibras

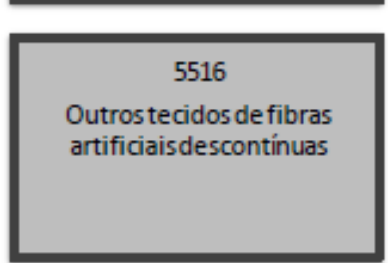

Fonte: Fabio Campos Fatalla com base na NESH, 2016

No capítulo 55 o primeiro ponto chave a ser considerado é o tipo de material dividido conforme segue:

- Cabo de filamentos

- Fibras 
- Fios

- Tecidos

O fluxograma da figura 78 mostra essa interpretação:

Figura 78 - Fluxograma de posições do capítulo 55

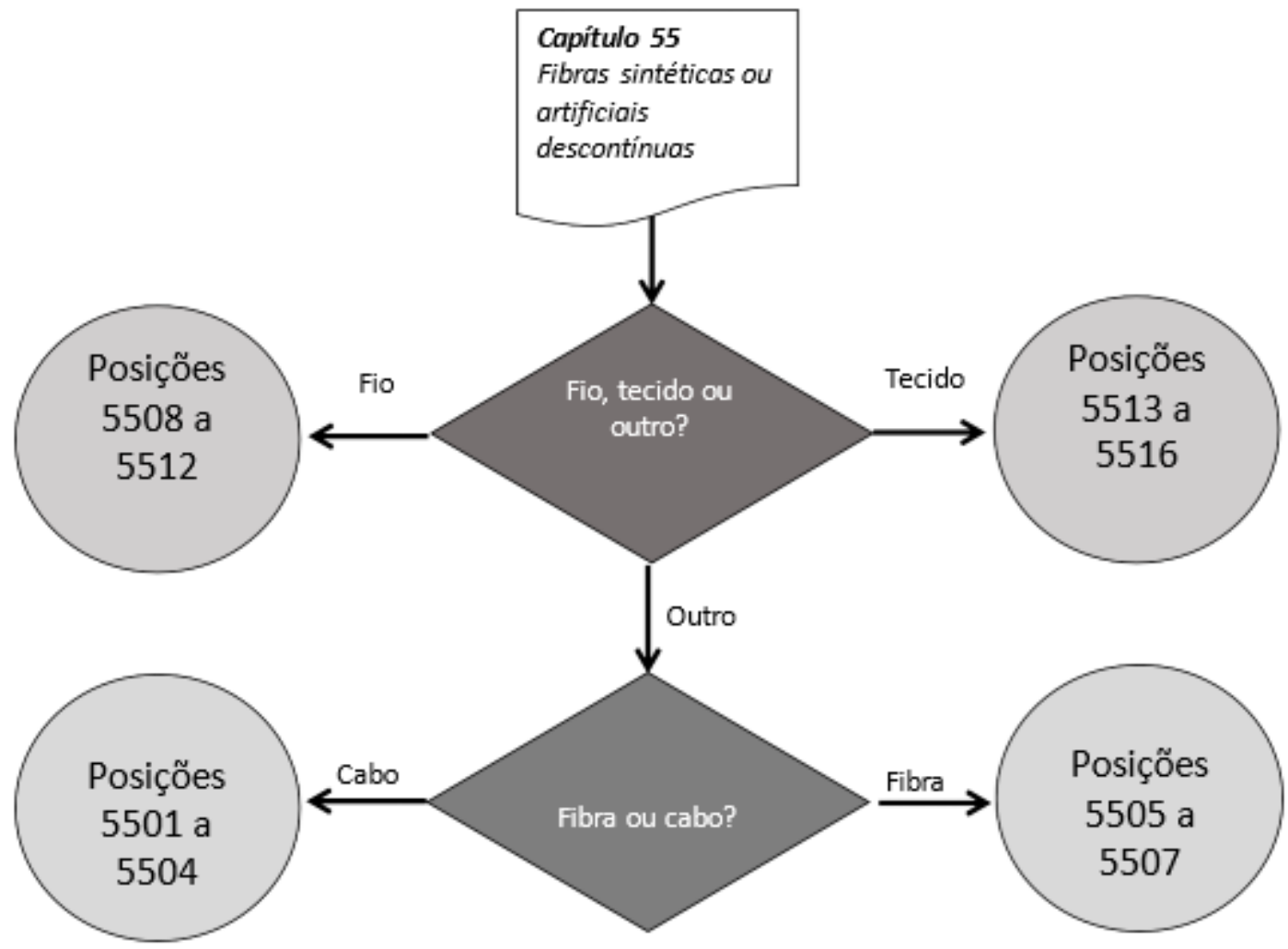

Fonte: Fabio Campos Fatalla, 2016

No caso do tecido em análise, o próximo grupo de pontos chaves inclui:

- Mínimo de 85 \% de fibras sintéticas descontínuas

- Menos de $85 \%$ de fibras sintéticas descontínuas combinadas com algodão

- Gramatura menor que $170 \mathrm{~g} / \mathrm{m}^{2}$

- Gramatura maior que $170 \mathrm{~g} / \mathrm{m}^{2}$

- Outros tecidos

- Sintéticos

$\circ$ Artificiais

Essa decisão está esquematizada no fluxograma da figura 79: 
Figura 79 - Fluxograma das posições 5513 a 5516

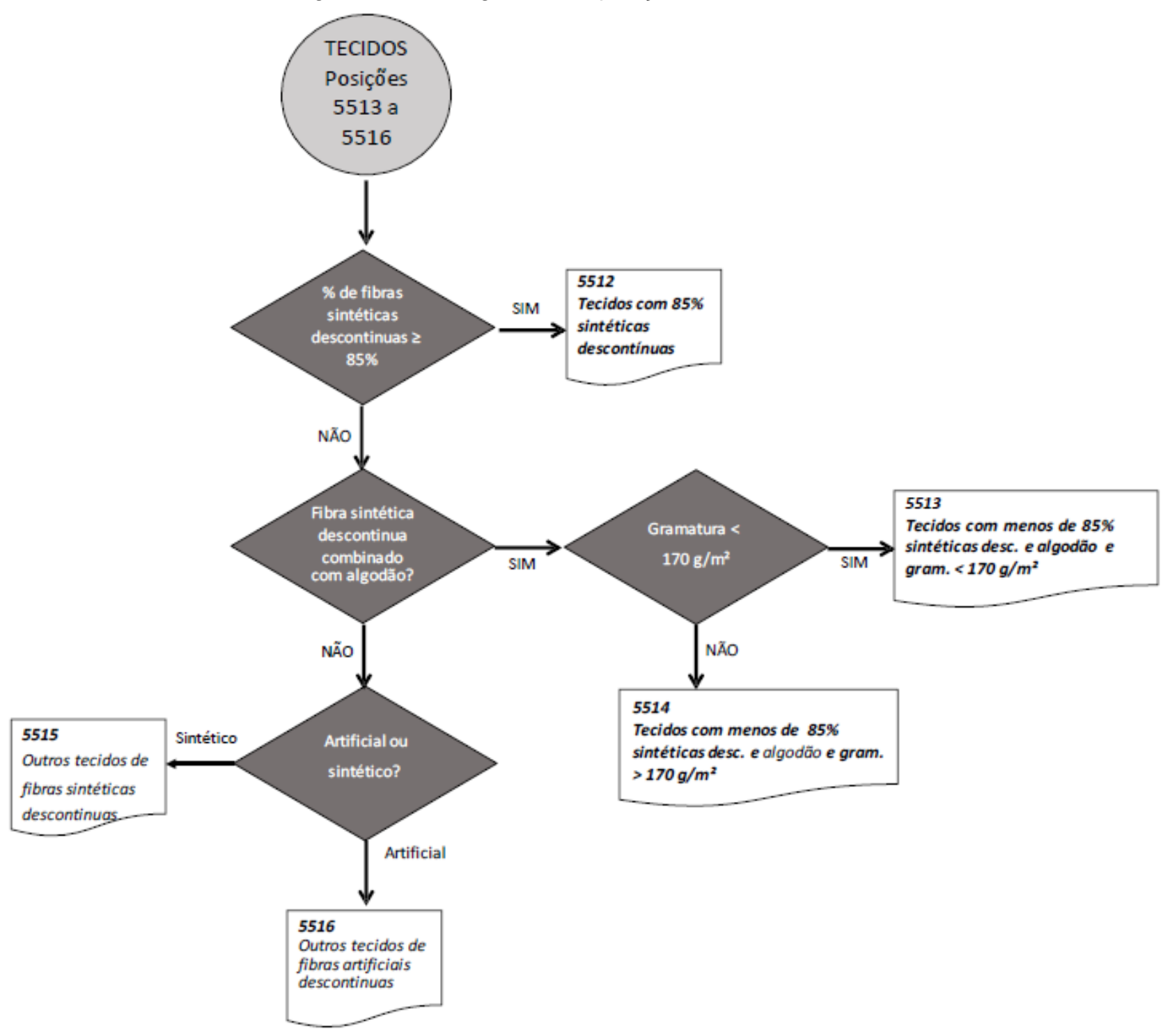

Fonte: Fabio Campos Fatalla, 2016

Para definição do primeiro dígito da subposição, considera-se o beneficiamento do tecido:

- Cru ou branqueado

- Tinto

- De fios de diversas cores

- Estampado

O fluxograma da figura 80 considera essa classificação: 
Figura 80 - Fluxograma para definição do primeiro dígito de subposição para a posição 5514

$\mathbf{5 2 1 4}$
Tecido com menos de $85 \%$, de fibras
sintéticas descontínuas, combinadas
principalmente com algodão

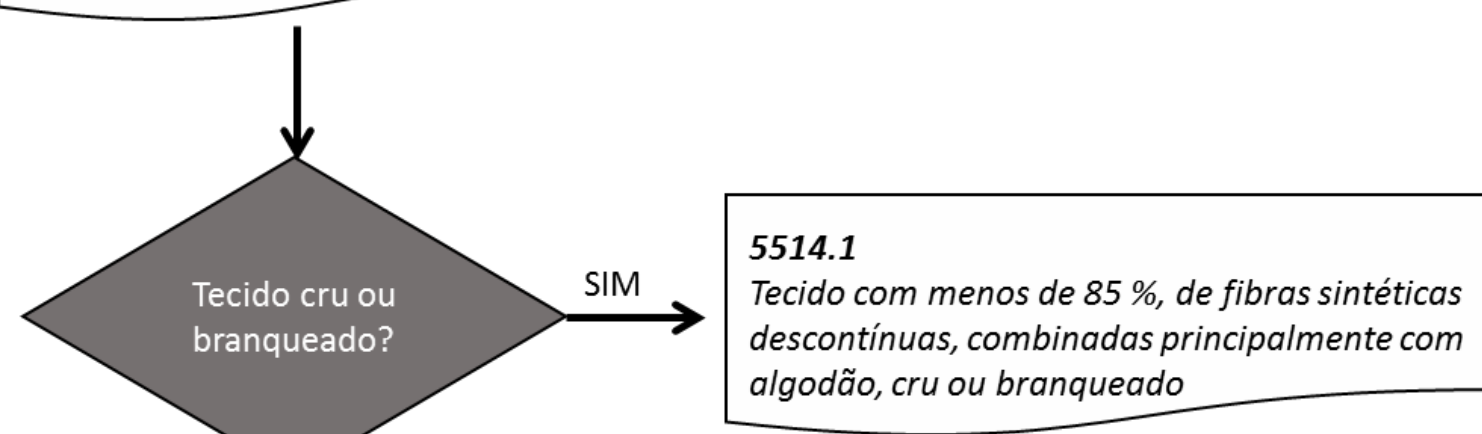

5514.2

Tecido com menos de $85 \%$, de fibras sinteticas descontínuas, combinadas principalmente com algodão, tinto

\section{3}

Tecido com menos de $85 \%$, de fibras sintéticas descontínuas, combinadas principalmente com algodão, com fios de diversas cores

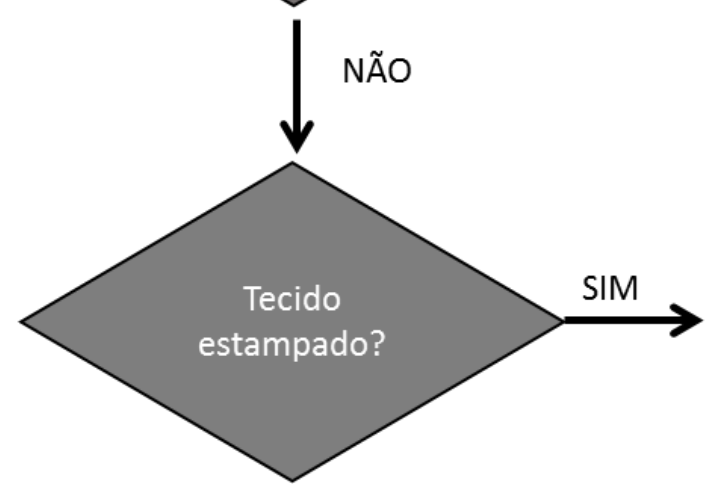

\section{4}

Tecido com menos de $85 \%$, de fibras sintéticas descontínuas, combinadas principalmente com algodão, estampado

Fonte: Fabio Campos Fatalla, 2016 
Finalmente para obtenção do segundo dígito da subposição deve-se considerar o ligamento e o tipo de fibra sintética (poliéster ou outra) como exemplificado no fluxograma da figura 81 a seguir. Como essa posição não apresenta itens ou subitens, todos apresentam final 00.

Figura 81 - Fluxograma para definição do segundo dígito de subposição para a posição 5514

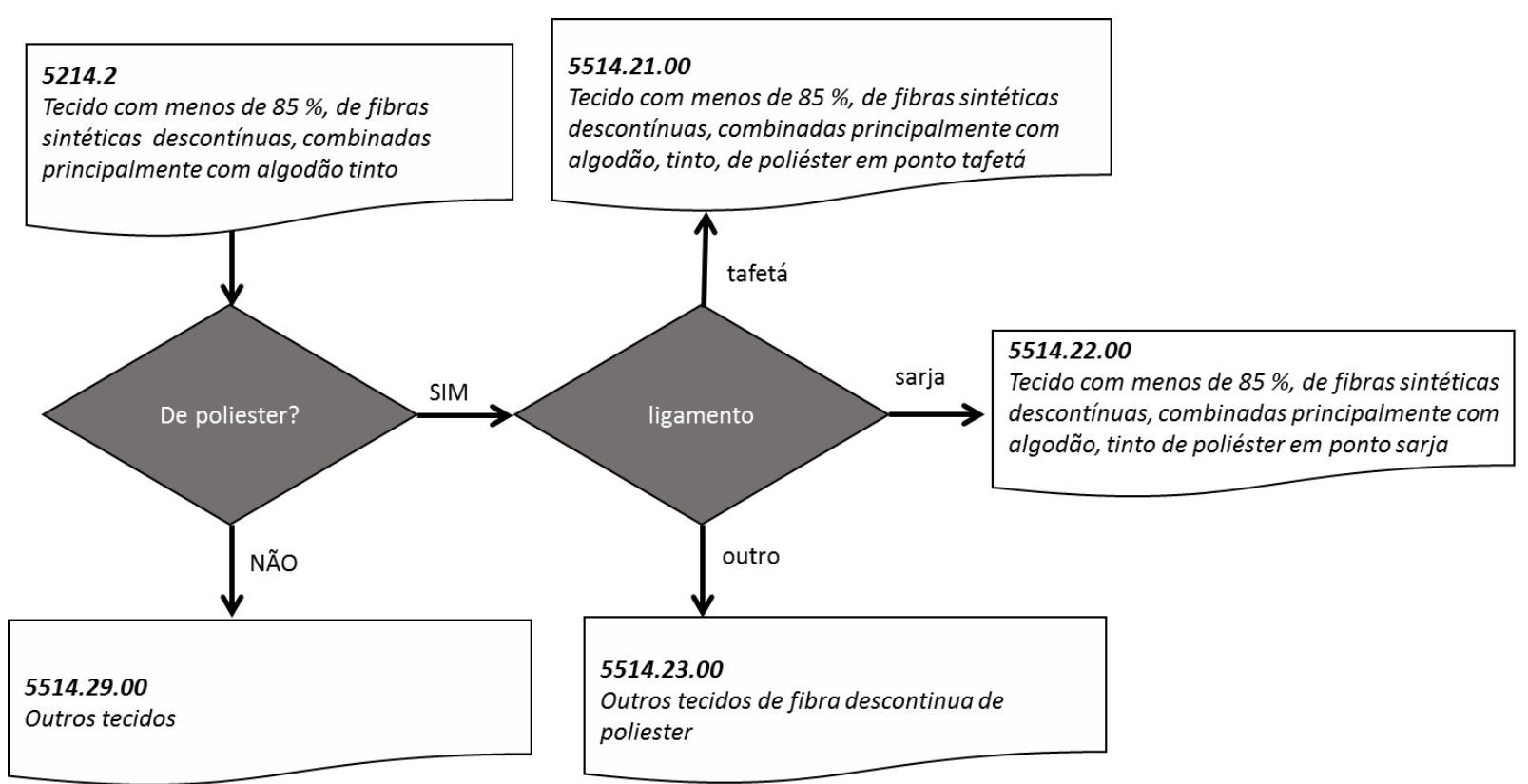

Fonte: Fabio Campos Fatalla, 2016

3.2.2.1 Pontos chaves para tecido de fibra sintética descontínua - resumo:

- Apresentação: cabo, fibra, fio ou tecido

- Porcentagem da fibra predominante e gramatura

- \% de material e combinação com outras fibras

- Tipo de beneficiamento

- Tipo de fibra (poliester)

- ligamento 


\subsection{CAPÍTULOS 56 A 60}

\subsubsection{Malha de urdume poliamida / elastano}

Nesse caso trata-se de tecido de malha que necessita esclarecer alguns pontos chaves iniciais para correta definição docapítulo em que se enquadra:

- Se é um produto confeccionado

- Se é renda de crochet, etiqueta, emblema ou semelhante

- Se é veludo, pelucia ou ataoalhado de malha

- Se é tecido impregnado, revestido ou recoberto

As definições para eslarecimentos desse pontos estão mostradas no fluxograma da figura 82 .

A malha de urdume em questão enquadra-se no capitulo 60 cujas posições estão mostradas na figura 83.

Analisando as posições do capitulo 60 chega-se aos seguintes pontos chaves:

- Veludo, pelucia ou atoalhado

- Largura

- Porcentagem de elastano

- Malha urdidura 
Figura 82 - Posições do capítulo 60

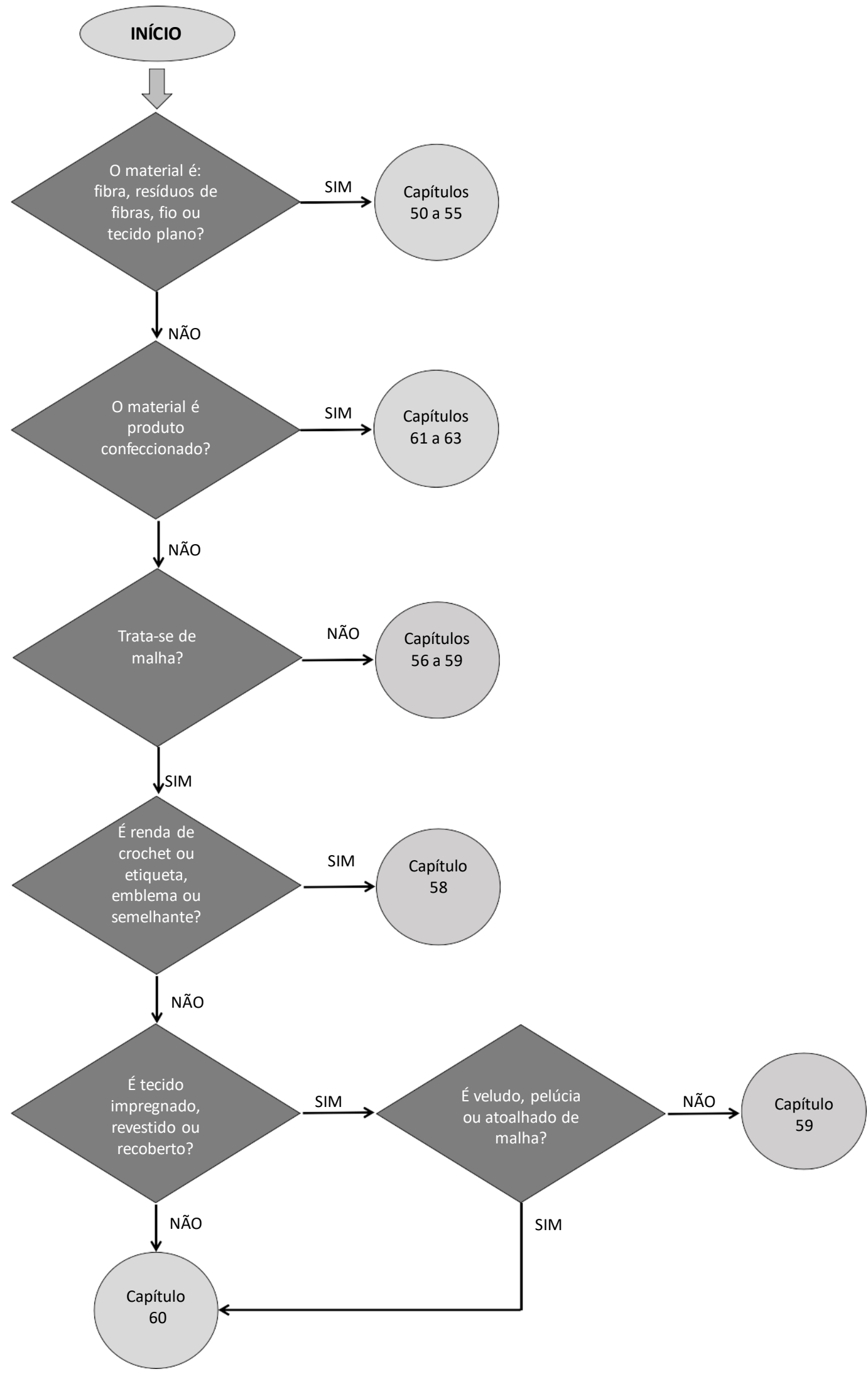

Fonte: Fabio Campos Fatalla, 2016 
A malha de urdume em questão enquadra-se no capitulo 60 cujas posições estão mostradas na figura 83.

Figura 83 - Posições do capítulo

60

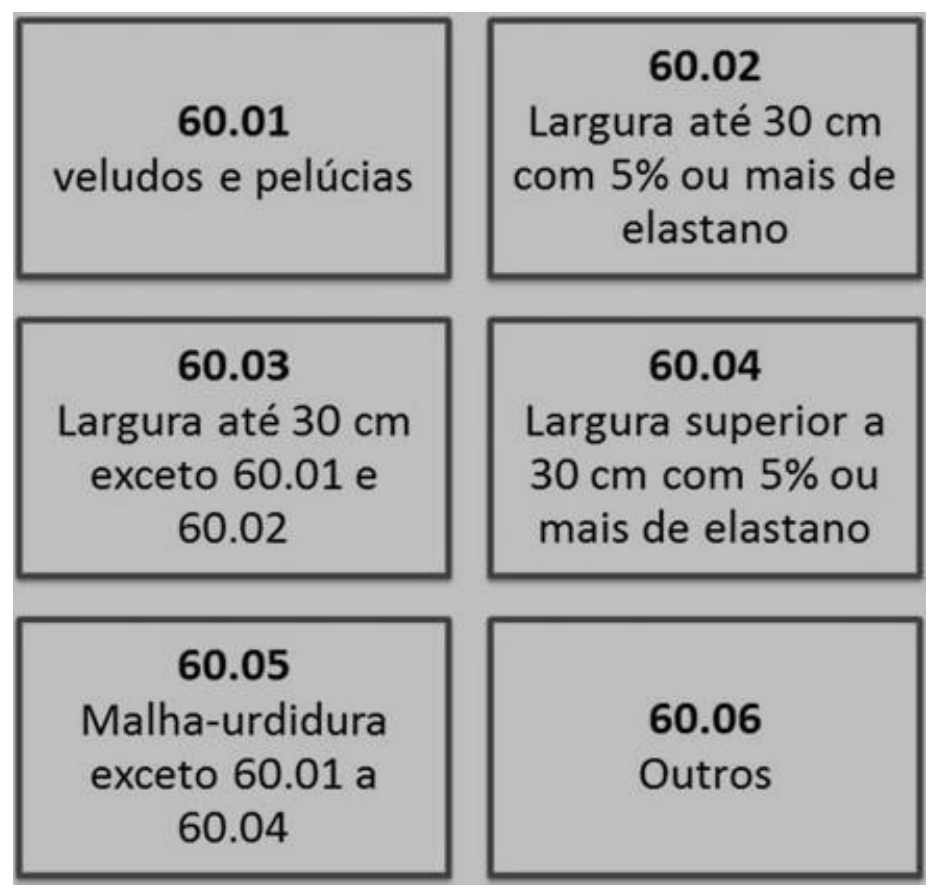

Fonte: Fabio Campos Fatalla com dados da NESH, 2016

Analisando as posições do capitulo 60 chega-se aos primeiros pontos chave:

- Veludo, pelucia ou atoalhado

- Largura

- Porcentagem de elastano

- Malha urdidura

O fluxograma da figura 84 mostra a definição desses fatores: 
Figura 84 - fluxograma de posições do capítulo 60

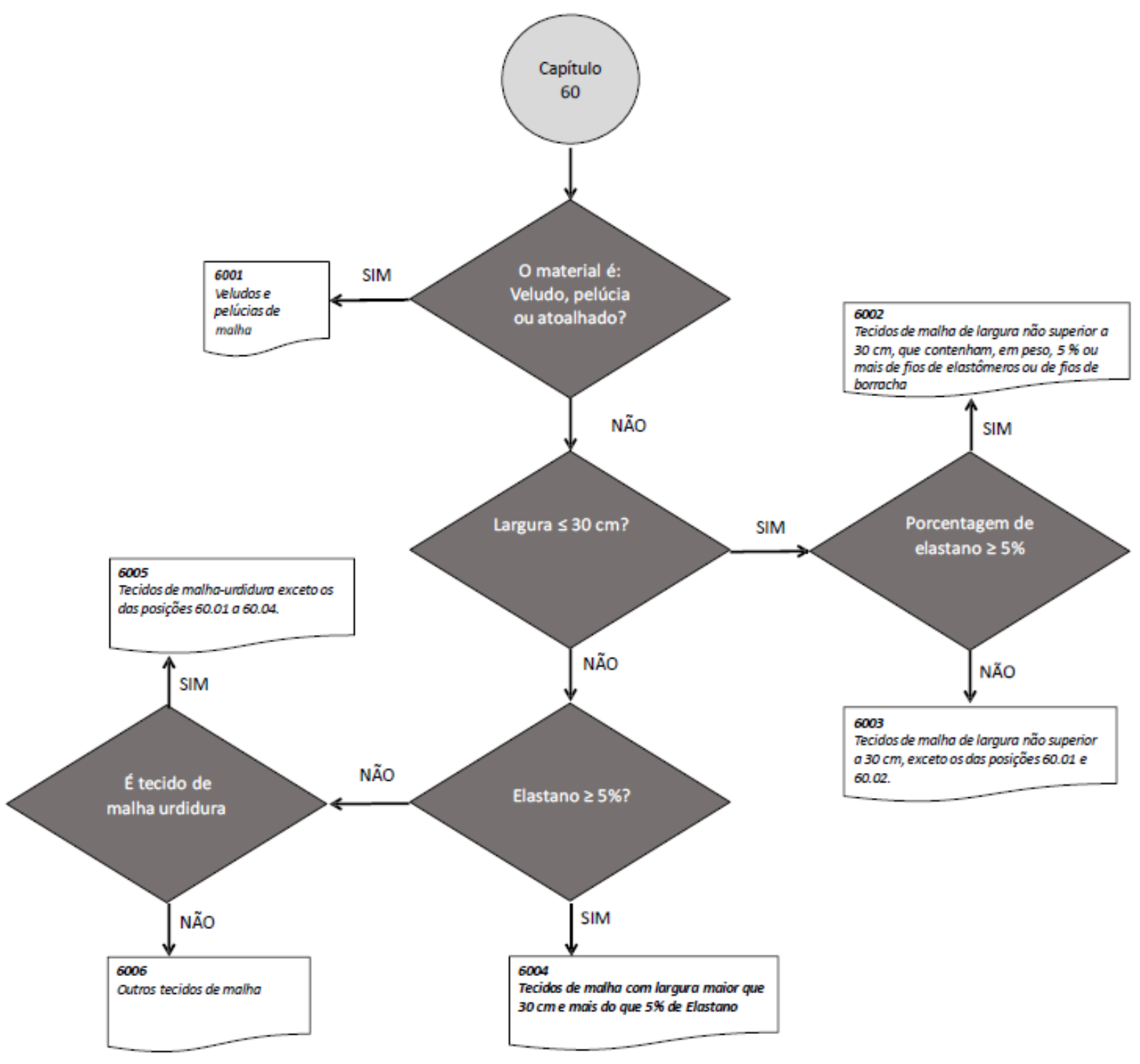

Fonte: Fabio Campos Fatalla, 2016

$\mathrm{Na}$ posição 6004 onde se enquadra o produto usado como exemplo o ponto chave para definição da subposição é:

- O tecido contém fios de borracha?

A análise desse ponto chave está mostrada no fluxo da figura 85: 
Figura 85 - fluxograma de posições do capítulo 60

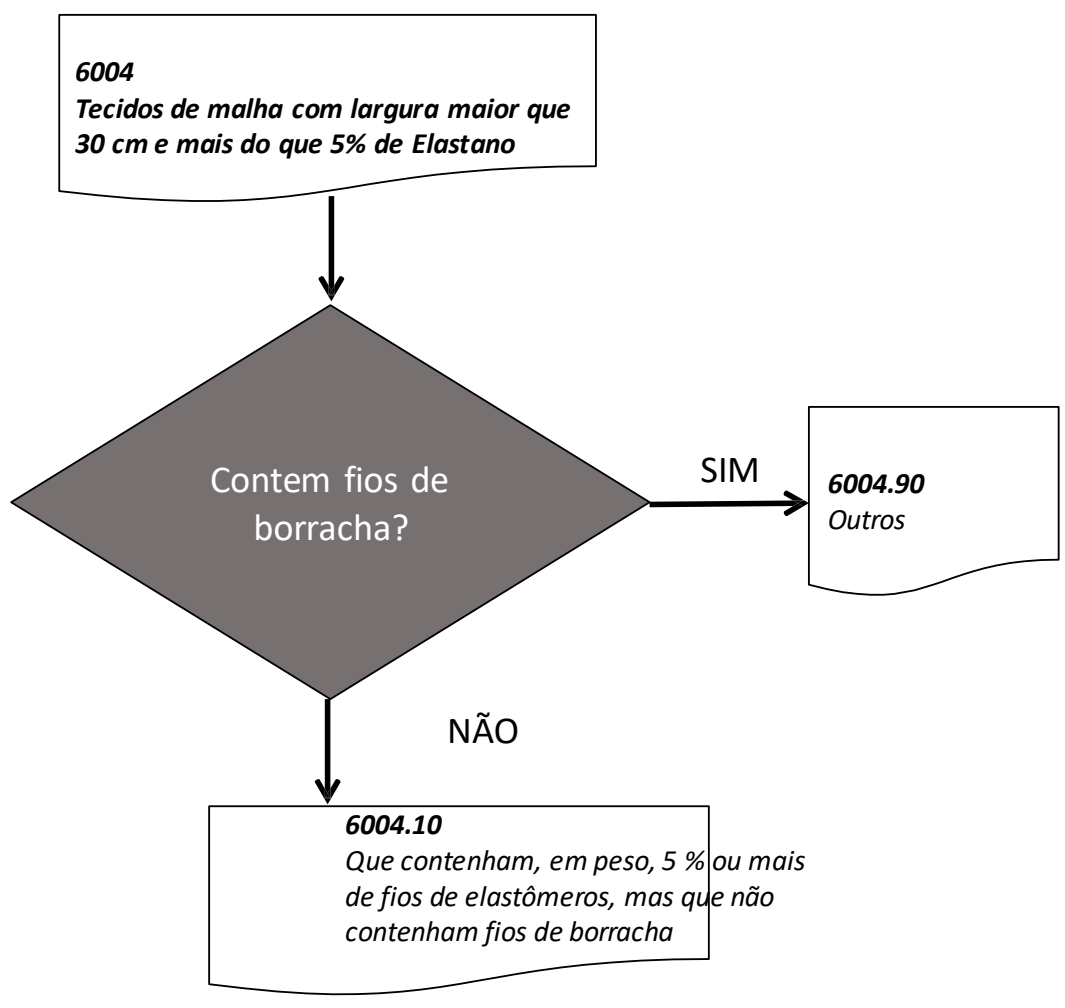

Fonte: Fabio Campos Fatalla, 2016

Para definição do item, o proximo ponto chave é:

- Materia prima predominante

Essa análise está mostrada no fluxograma da figura 86.

Finalmente, para definição do sub item leva-se em consideração o tipo de beneficiamento:

- Cru ou branqueado

- Tinto

- De fios de diversas cores

- Estampado

Essa análise está mostrada no fluxograma da figura 87. 
Figura 86 - fluxograma de itens da subposição 6004.10

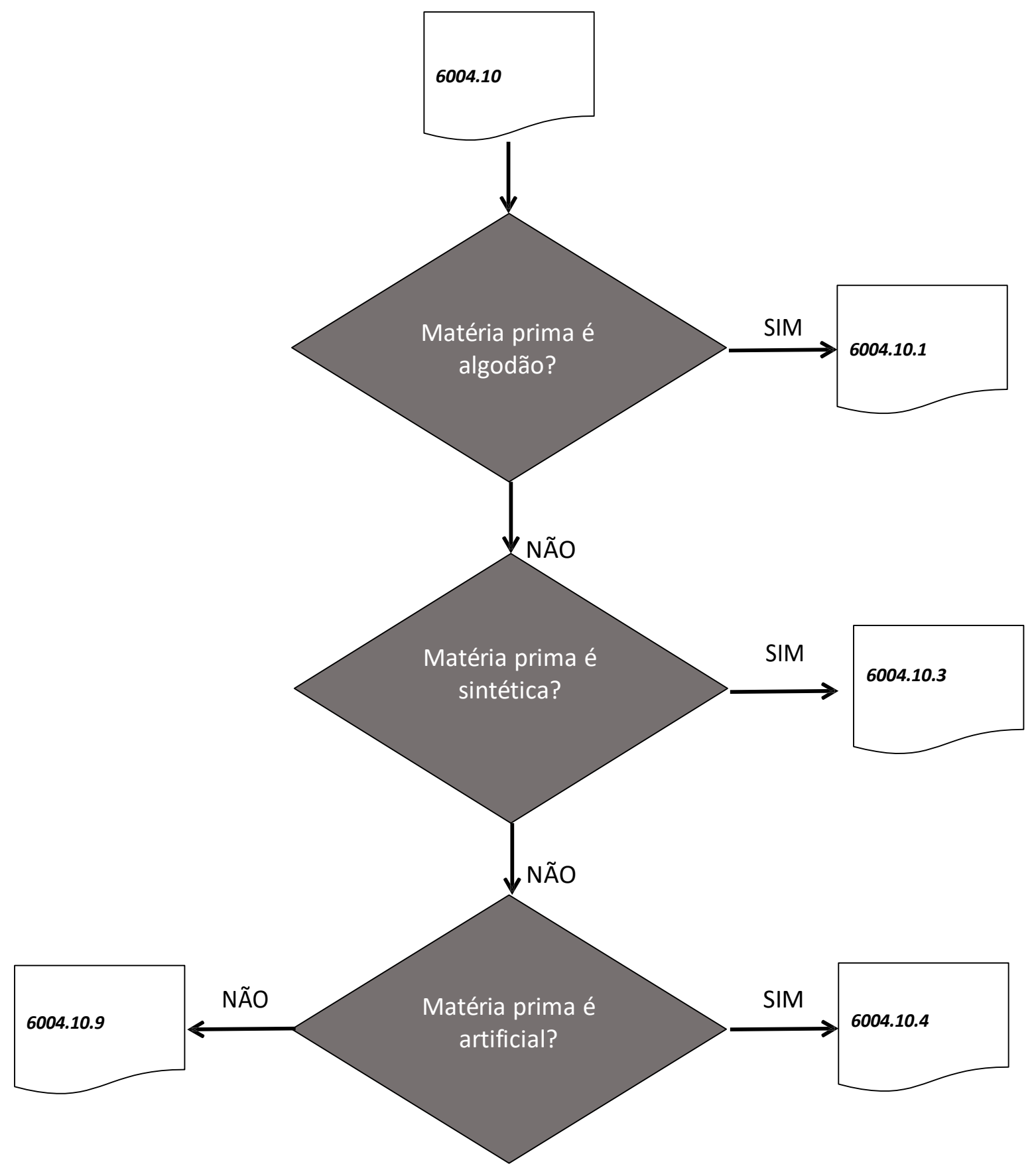

Fonte: Fabio Campos Fatalla, 2016 
Figura 87 - fluxograma de itens da subposição 6004.10

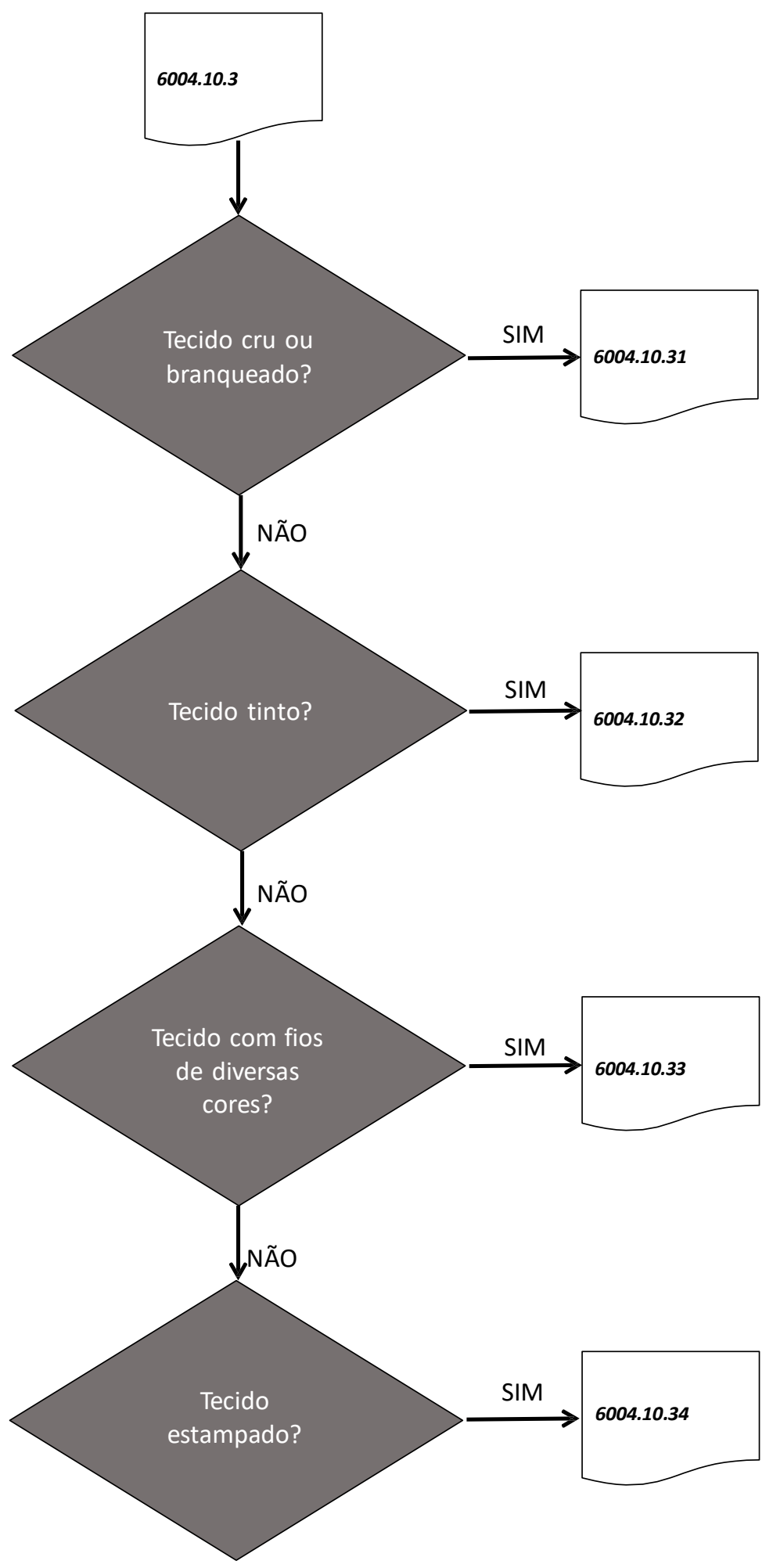

Fonte: Fabio Campos Fatalla, 2016 


\subsection{CAPÍTULOS 61 A 63}

\subsubsection{Vestido de tecido plano em algodão}

Os capítulos 61 a 63 envolvem produtos confeccionados, conforme mostrado na figura 88 .

Figura 88 - capítulos 61 a 63

\begin{tabular}{|l|l|}
\hline 61 & VESTUÁRIO E SEUS ACESSÓRIOS, DE MALHA \\
\hline 62 & VESTUÁRIO E SEUS ACESSÓRIOS, EXCETO DE MALHA \\
\hline 63 & $\begin{array}{l}\text { OUTROS ARTEFATOS TÊXTEIS CONFECCIONADOS; SORTIDOS; ARTEFATOS DE } \\
\text { MATÉRIAS TÊXTEIS, CALÇADOS, CHAPÉUS E ARTEFATOS DE USO SEMELHANTE, } \\
\text { USADOS; TRAPOS }\end{array}$ \\
\hline
\end{tabular}

Fonte: Fabio Campos Fatalla com base na NESH, 2016

Para definição do capítulo, alguns pontos chaves são inicialmente necessários:

- Se o material é de malha

- Se é sutiã, cinta, espartilho, liga, suspensório ou semelhante

- Se é vestuário

- Se é produto usado ou trapo

O fluxograma da figura 89 mostra essas definições.

O produto tomado como exemplo (vestido) está alocado no capítulo 62. As posições do capítulo 62 estão mostradas na figura 90. Analisando essas posições é possível verificar os pontos chaves para sua definição.

Num primeiro grupo define-se:

- Se é vestuário de bebê

- Se é produto confeccionado com feltro ou falso tecido

- Se é produto confeccionado com tecidos impregnados ou revestidos Num segundo grupo define-se:

- Se é algum tipo de acessório Num terceiro grupo define-se:

- Se é algum vestuário especifico: esporte, banho, etc. ou lingerie, modeladores, etc.

- Se é vestuário masculino ou feminino. 
Figura 89 - fluxograma para os capítulos 61 a 63

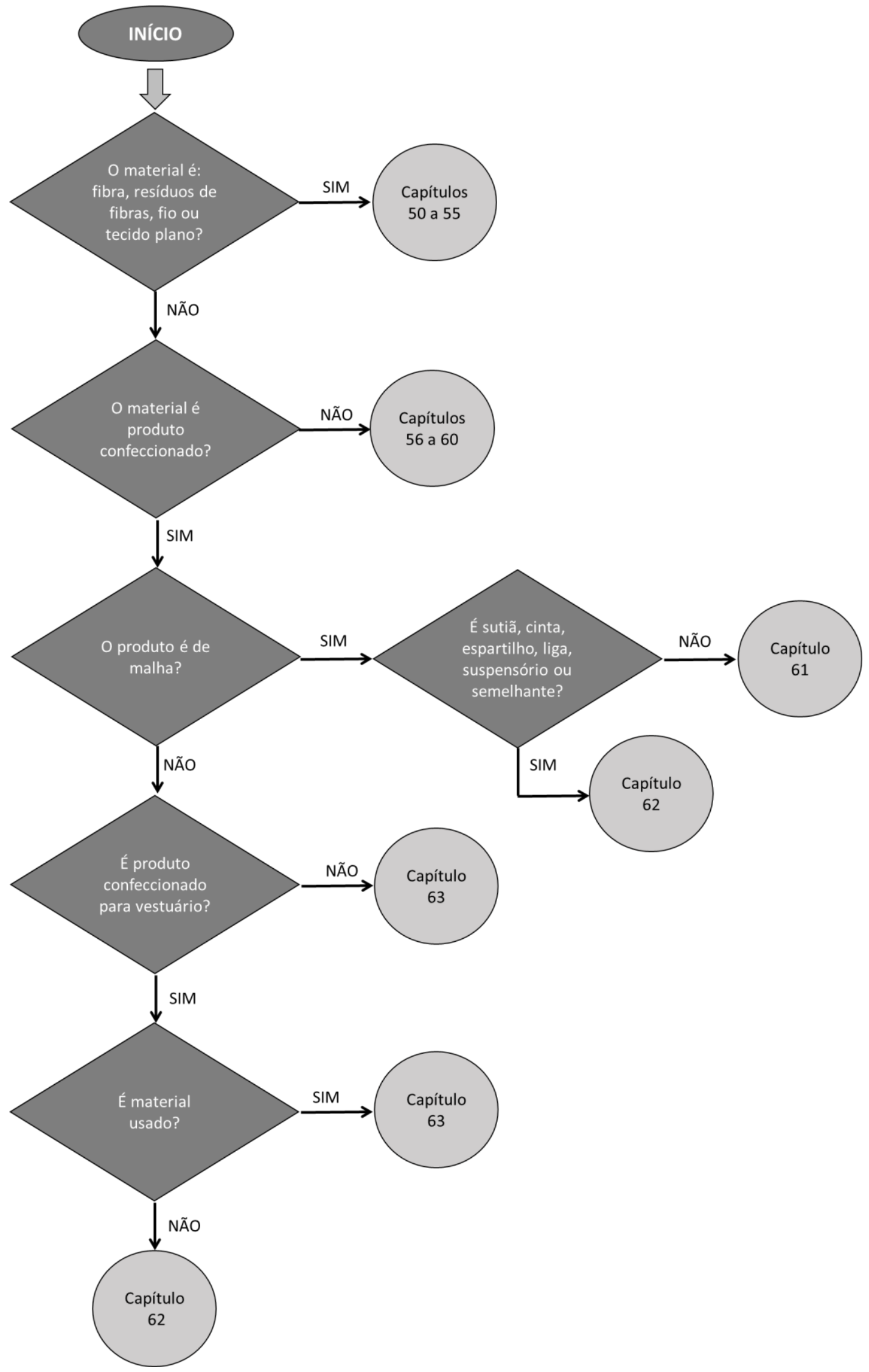

Fonte: Fabio Campos Fatalla, 2016 
Figura 90 - posições do capítulo 62

\begin{tabular}{|c|c|c|}
\hline $\begin{array}{c}\text { 62.01 -Sobretudos, japonas, gabões, } \\
\text { capas, anoraques, casacos e semelhantes, } \\
\text { de uso masculino, exceto os artefatos da } \\
\text { posição } 62.03 \text {. }\end{array}$ & $\begin{array}{l}\text { 62.16 - Luvas, } \\
\text { mitenes e }\end{array}$ & $\begin{array}{l}\text { 62.08 - Corpetes, combinações, anáguas, } \\
\text { calcinhas, camisolas, pijamas, déshabillés, } \\
\text { roupões de banho, penhoares e } \\
\text { semelhantes, de uso feminino. }\end{array}$ \\
\hline $\begin{array}{l}\text { 62.02 - Mantôs, capas, anoraques, casacos } \\
\text { e semelhantes, de uso feminino, exceto os }\end{array}$ & \multirow{3}{*}{$\begin{array}{c}\text { Cap. } 62 \\
\text { VESTUÁRIO E } \\
\text { SEUS } \\
\text { ACESSÓRIOS, } \\
\text { EXCETO DE } \\
\text { MALHA }\end{array}$} & $\begin{array}{l}\text { 62.09-Vestuário e seus acessórios, para } \\
\text { bebês. }\end{array}$ \\
\hline \multirow{2}{*}{$\begin{array}{l}\text { 62.03 - Ternos, conjuntos, paletós, calças, } \\
\text { jardineiras, bermudas e shorts (calções) } \\
\text { (exceto de banho), de uso masculino. }\end{array}$} & & $\begin{array}{c}\mathbf{6 2 . 1 0} \text { - Vestuário confeccionado com as } \\
\text { matérias das posições } 56.02,56.03,59.03 \text {, } \\
59.06 \text { ou } 59.07 . .\end{array}$ \\
\hline & & $\begin{array}{l}\text { 62.11 - Abrigos para es porte macacões e } \\
\text { conjuntos de esqui, maiôs, biquinis, shorts } \\
\text { (calções) e sungas de banho. }\end{array}$ \\
\hline $\begin{array}{c}\text { jardineiras, bermudas e shorts } \\
\text { (calções)(exceto de banho), de uso } \\
\text { feminino. }\end{array}$ & $\mathbf{6 2 . 1 7 - O u t r o s}$ & $\begin{array}{c}\text { 62.12 - Sutiãs, cintas, espartilhos, } \\
\text { suspensórios, ligas e artefatos } \\
\text { semelhantes, e suas partes, mesmo de } \\
\text { malha }\end{array}$ \\
\hline 62.05 - Camisas de uso masculino & & 62.13 -Lenços de assoar e de bolso. \\
\hline $\begin{array}{c}\text { 62.06-Camisas, blusas, blusas chemisiers, } \\
\text { de uso feminino }\end{array}$ & $\begin{array}{l}\text { vestuário ou } \\
\text { dos seus } \\
\text { acessórios, }\end{array}$ & $\begin{array}{c}\text { 62.14 -Xales, echarpes, lenços de pescoço, } \\
\text { cachenês, cachecóis, mantilhas, véus e } \\
\text { artefatos semelhantes. }\end{array}$ \\
\hline $\begin{array}{l}\text { 62.07 - Cuecas, ceroulas, camisolões, } \\
\text { pijamas, roupões de banho, robes e } \\
\text { semelhantes, de uso masculino. }\end{array}$ & $\begin{array}{l}\text { exceto as da } \\
\text { posição } 62.12 \text {. }\end{array}$ & $\begin{array}{l}\text { 62.15 - Gravatas, gravatas-borboletas e } \\
\text { plastrons. }\end{array}$ \\
\hline
\end{tabular}

Fonte: Fabio Campos Fatalla com base na NESH, 2016

O Fluxograma da figura 91 mostra a primeira fase da definição da posição. Considerando que o produto em análise é vestuário feminino (vestido), numa segunda fase (fluxograma da figura 92) é necessário definir o próximo ponto chave para classificação da posição:

- Grupo de tipo de peças afins

Para definir o primeiro digito da subposição o próximo ponto chave é:

- Tipo de peça dentro do grupo

Essa definição está esquematizada no fluxograma da figura 93.

Finalmente o segundo dígito da subposição baseia-se no último ponto chave:

- Matéria prima predominante

Essa definição está esquematizada no fluxograma da figura 94.

Essa posição não considera itens e subitens, portanto os dois últimos dígitos da classificação são: 00. 
Figura 91 - Posições do capítulo 62 (1)

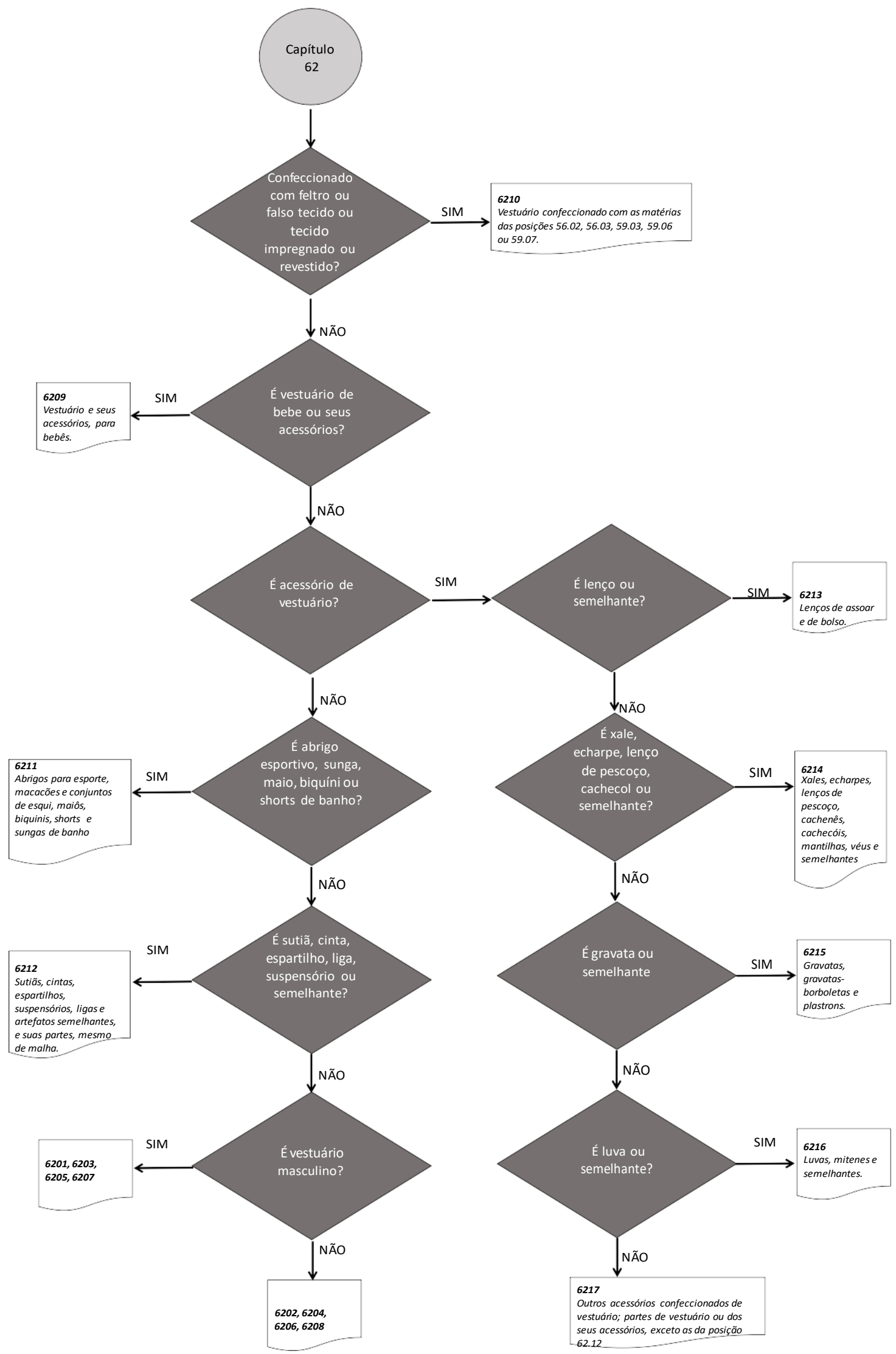

Fonte: Fabio Campos Fatalla, 2016 
Figura 92 - Posições do capítulo 62 (2)

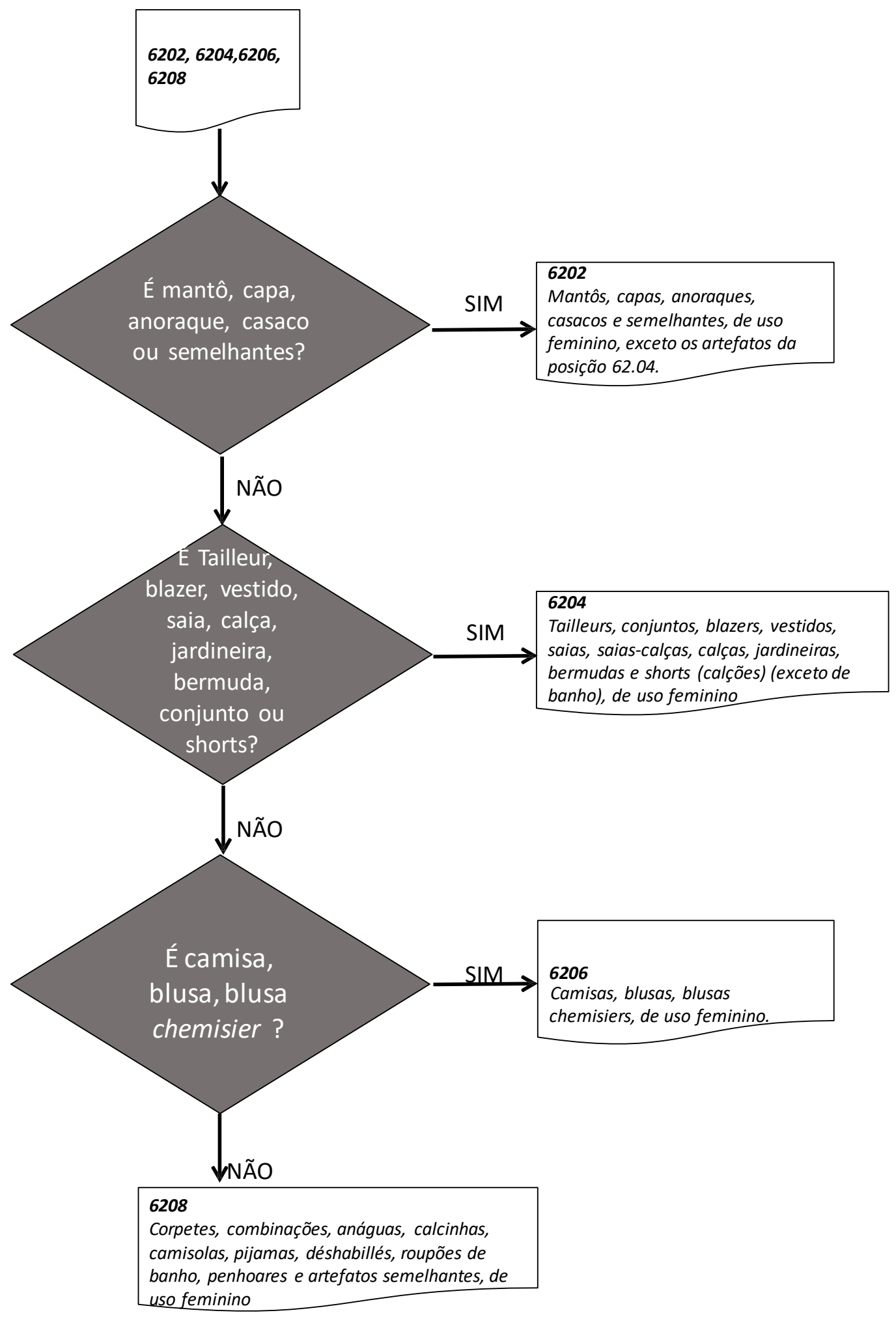

Fonte: Fabio Campos Fatalla, 2016 
Figura 93 - Subposições da posição 6204 (1ํ dígito)

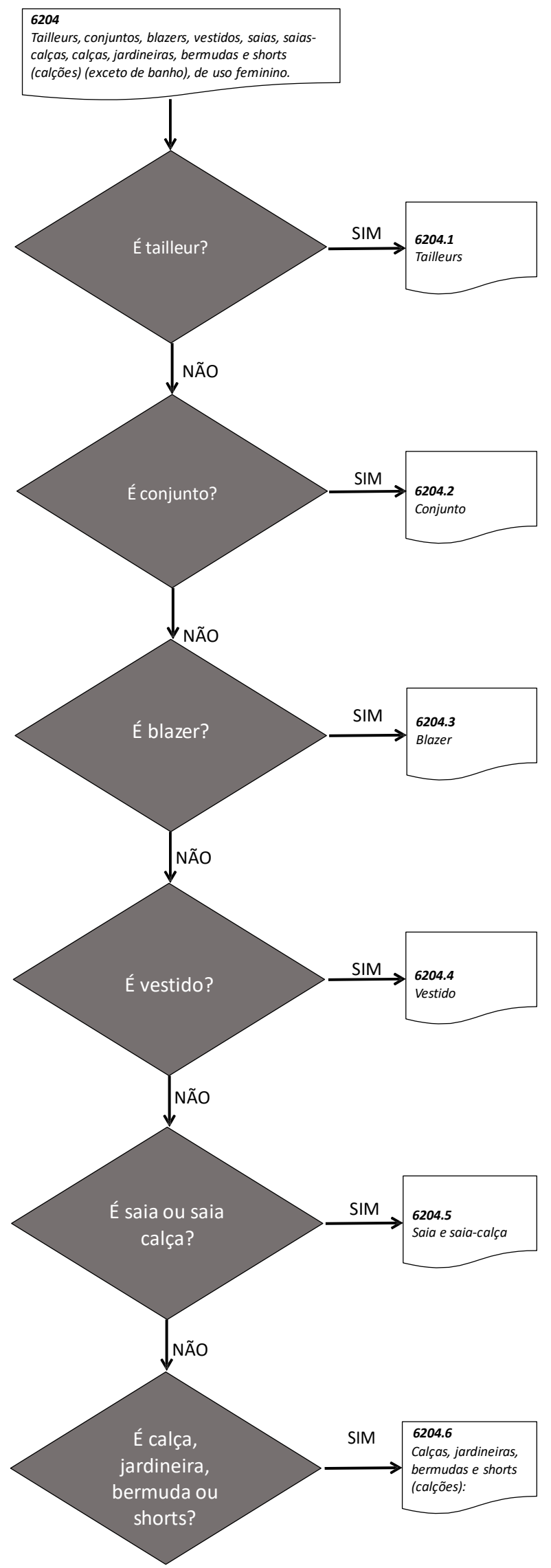

Fonte: Fabio Campos Fatalla, 2016 
Figura 94 - Subposições da posição 6204 (2ํ dígito)

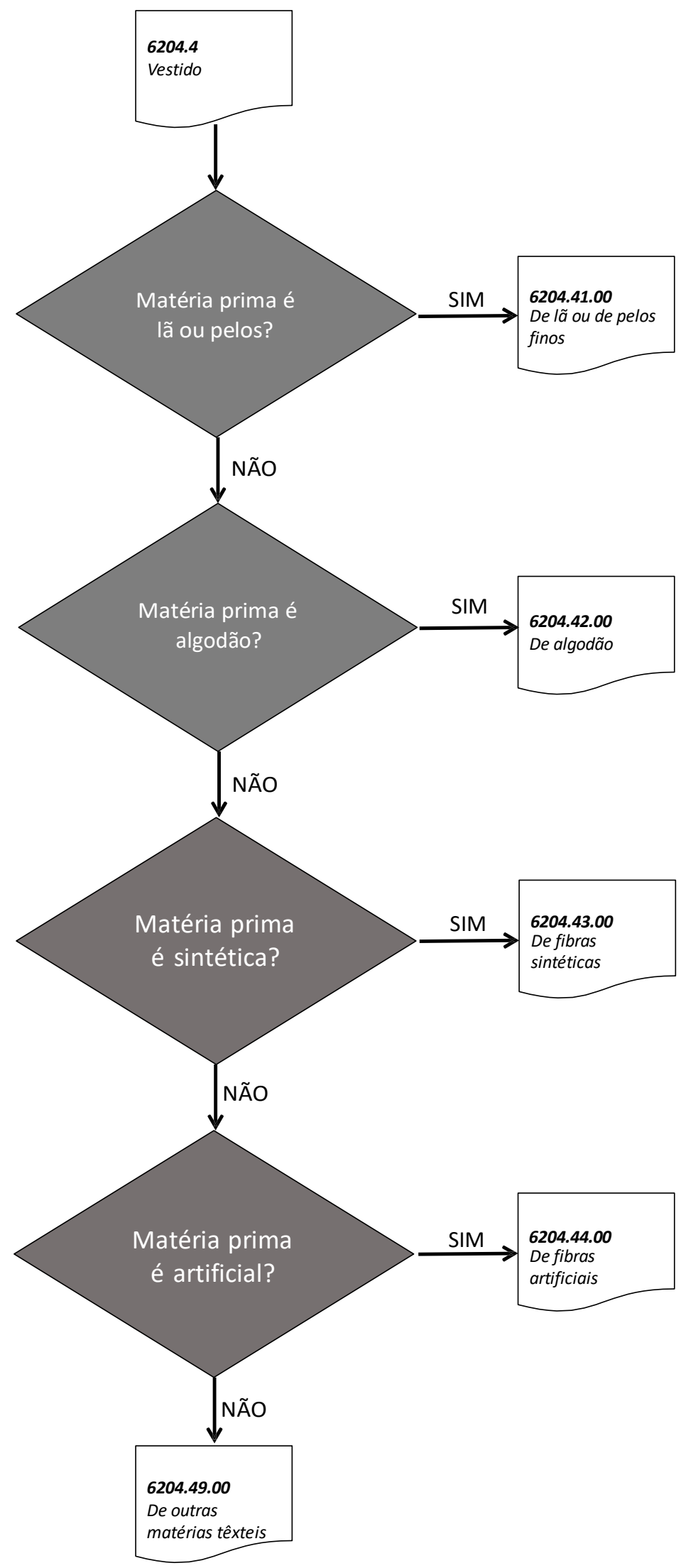

Fonte: Fabio Campos Fatalla, 2016 
3.4.1.1 Pontos chaves para vestido de algodão - resumo:

- Produzido com material especial: feltro ou falso tecido, tecido impregnado ou revestido?

- Roupa de bebê?

- Acessorio de vestuário?

- Vestuário específico: roupa de esporte ou banho, lingerie ou modeladores?

- Vestuário masculino ou feminino?

- Grupo de tipos de peças afins

- Tipo de peça

- Matéria prima predominante

\section{RESULTADOS E DISCUSSÕES}

Os fluxogramas definidos no capítulo III - Materiais e métodos foram aplicados na classificação dos seguintes produtos:

- Fio $100 \%$ algodão

- Tecido plano poliéster/viscose

- Tecido de malha por urdume poliamida/elastano

- Vestido de tecido plano $100 \%$ algodão

\subsection{FIO $100 \%$ ALGODÃO}

\subsubsection{Descrição do material}

O produto em análise trata-se fio $100 \%$ algodão cru cardado OE retorcido a dois cabos de título $\mathrm{Ne} 20 / 2$ em cones.

\subsubsection{ADE COANA 22:}

I - Quanto à natureza da matéria-

$$
\begin{aligned}
& \text { prima } 1 \text { - Natural } \\
& 1.1 \text { - Vegetais } \\
& 1.1 .1 \text { - Algodão } \\
& 1.1 .2 \text { - Linho } \\
& 1.1 .3 \text { - Rami } \\
& 1.1 .4 \text { - Juta } \\
& 1.1 .5 \text { - Outras (especificar) }
\end{aligned}
$$

3 - Composição: $100 \%$ algodão

II - Quanto ao processo de 
fabricação 1 - Fio de fibra

descontínua

\section{1 - Fio cardado}

\subsection{1 - Filatório de Anéis}

1.1.2 - Filatório a rotor

III - Quanto à torção

1 - Fio simples (singelo)

2 - Fio retorcido ou retorcido múltiplo

IV - Quanto ao beneficiamento

1 - Fio cru

2 - Fio tinto

3 - Fio branqueado

4 - Fio fantasia

5 - Outros (especificar)

V - Quanto à forma de

acondicionamento 1 - Bobina

2 - Cone

3 - Cops

4 - Outras (especificar)

IV - Quanto a outras informações

1 - Título (em dTex): 301,2 dTex por cabo (602,4 dTex total)

2 - Tenacidade (se aplicável) (em cN/Tex)

3 - Número de torções (voltas/metro)

\subsubsection{Fluxogramas}

\subsubsection{Fluxograma 1 - grupo de capítulos}

Como se trata de fio, segundo o fluxo, o produto deve ser classificado nos capítulos 50 a 55 (figura 95):

Figura 95 - classificação de fio de algodão - grupo de capítulos

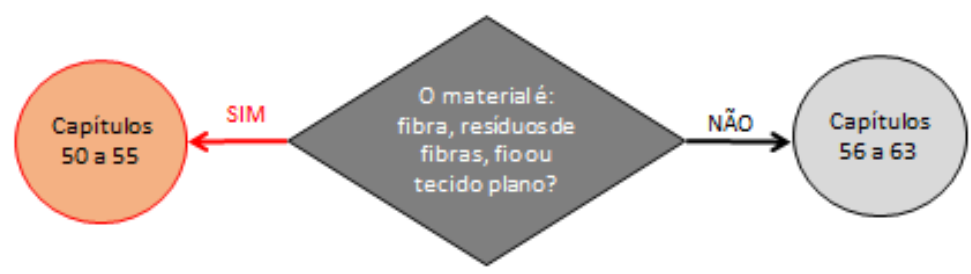


4.1.3.2 Fluxograma 2 - capítulo

Como a matéria prima é natural, vegetal, predominantemente algodão, de acordo com o fluxograma da figura 96, devemos classifica-la no capitulo 52 - Algodão.

Figura 96 -classificação de fio de algodão - capítulo

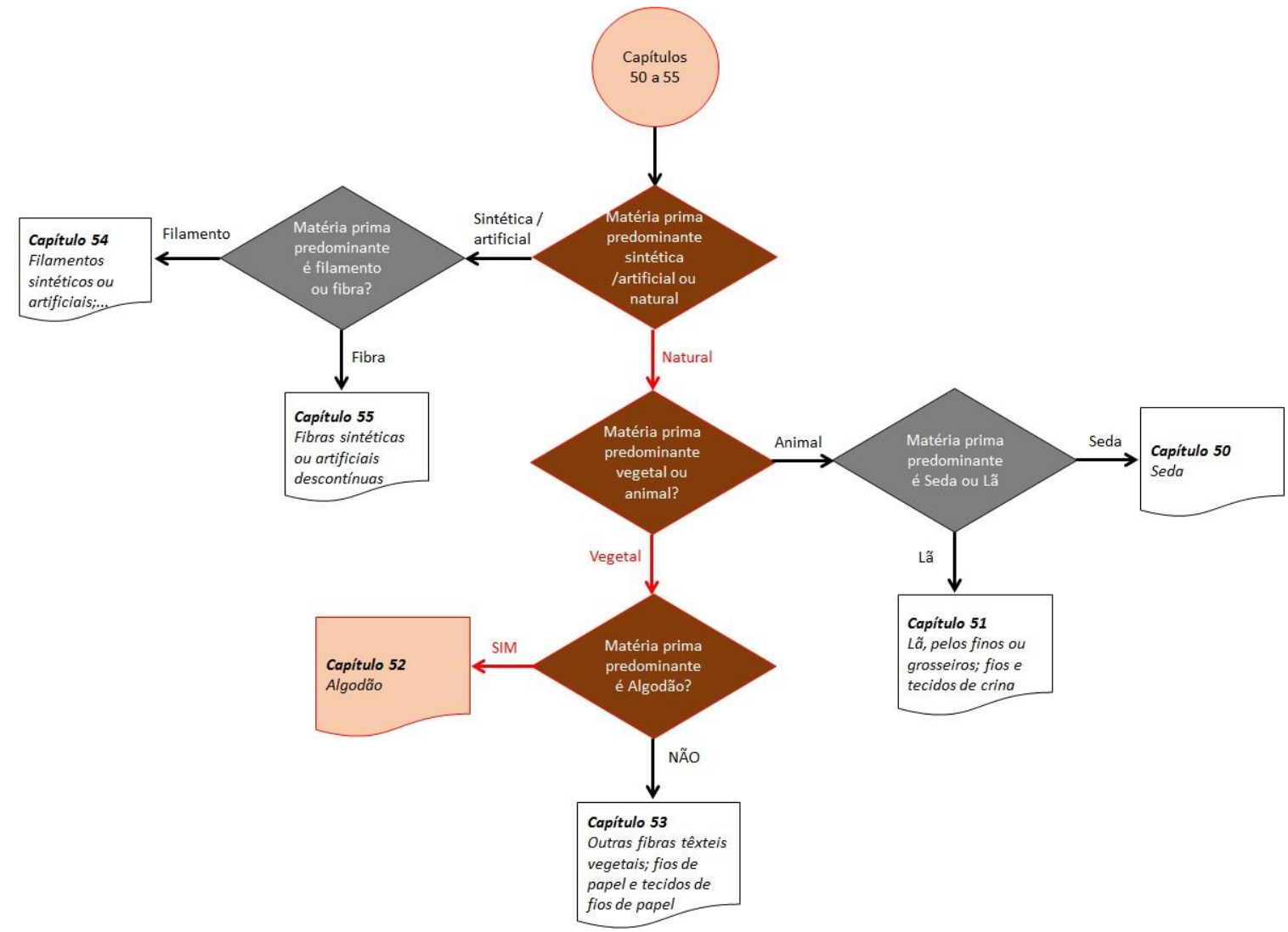

Fonte: Fabio Campos Fatalla, 2016

\subsubsection{Fluxograma 3 - posição (1)}

Como se trata de fio, conforme o fluxograma da figura 97 , o produto deve ser classificado nas posições 5204 a 5207.

Figura 97 -classificação de fio de algodão - posição (1)

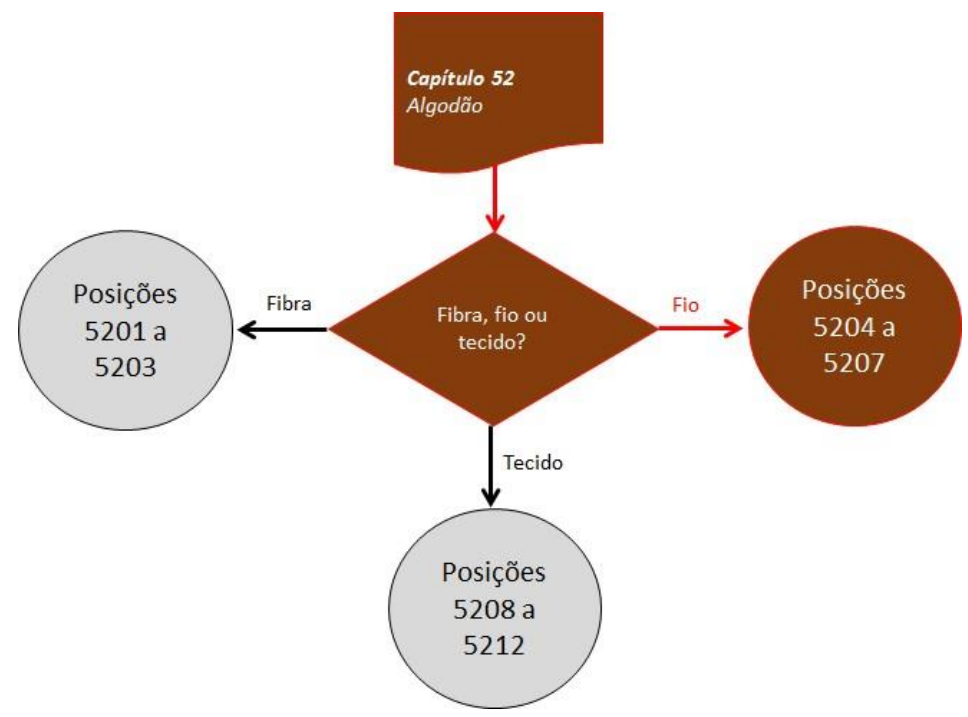

Fonte: Fabio Campos Fatalla, 2016 


\subsubsection{Fluxograma 4 - posição (2)}

Como não se trata de linha de costura e o fio está acondicionado em cones e não para venda a retalho e contém $85 \%$ ou mais de algodão (100\%), de acordo com o fluxograma (figura 98) chega-se à posição 5205.

\section{Figura 98 - Classificação de fio de algodão - posição}

(2)

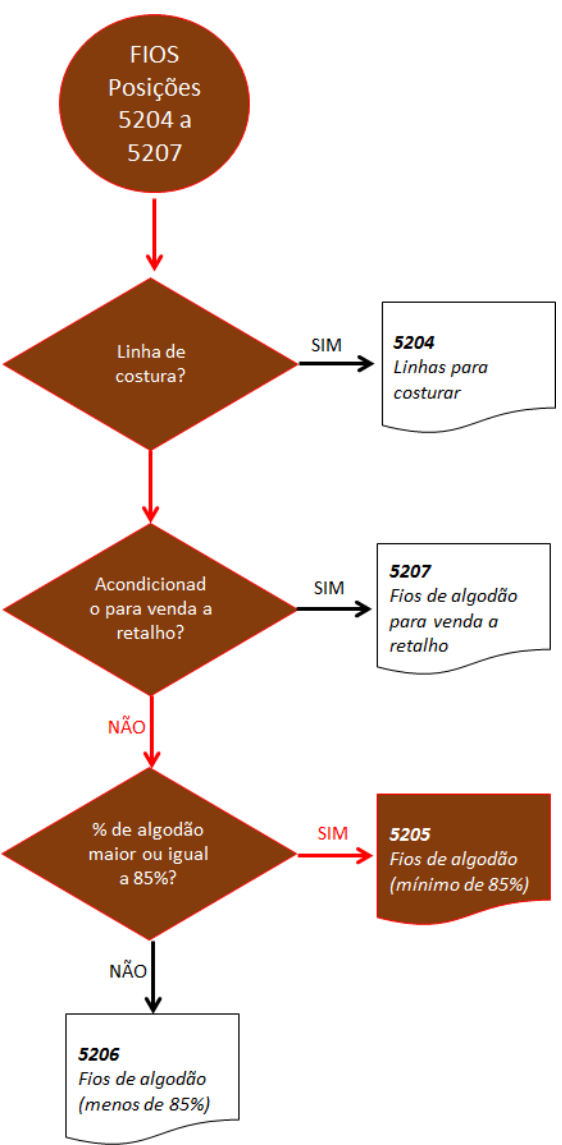

Fonte: Fabio Campos Fatalla, 2016

\subsubsection{Fluxograma 5 - subposição nível 1}

Como não se trata de fio retorcido (2 cabos) não penteado, de acordo com o fluxograma (figura 99) chega-se ao primeiro nível da subposição: 5205.3. 
Figura 99 - Classificação de fio de algodão - subposição nível 1

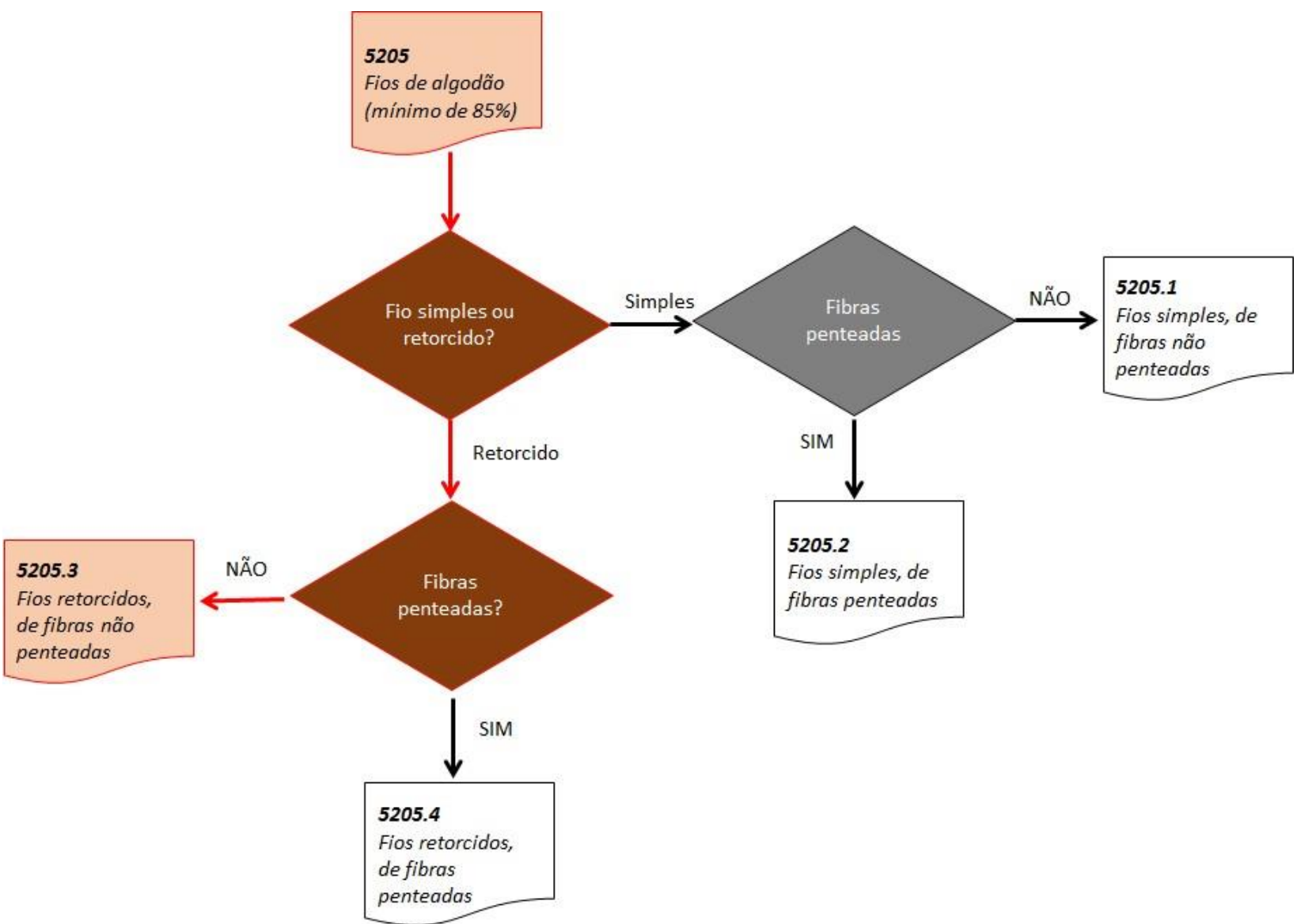

Fonte: Fabio Campos Fatalla, 2016

\subsubsection{Fluxograma 6 - subposição nível 2}

Como o título do fio é de 301,2 dtex por cabo está entre 232,56 e 714,29, de acordo com o fluxograma (figura 100) e, considerando que essa subposição não possui itens e subitens, chega-se ao segundo nível da subposição e à classificação final do artigo: $\underline{5205.32 .00}$. 
Figura 100 - Classificação de fio de algodão - subposição nível 2

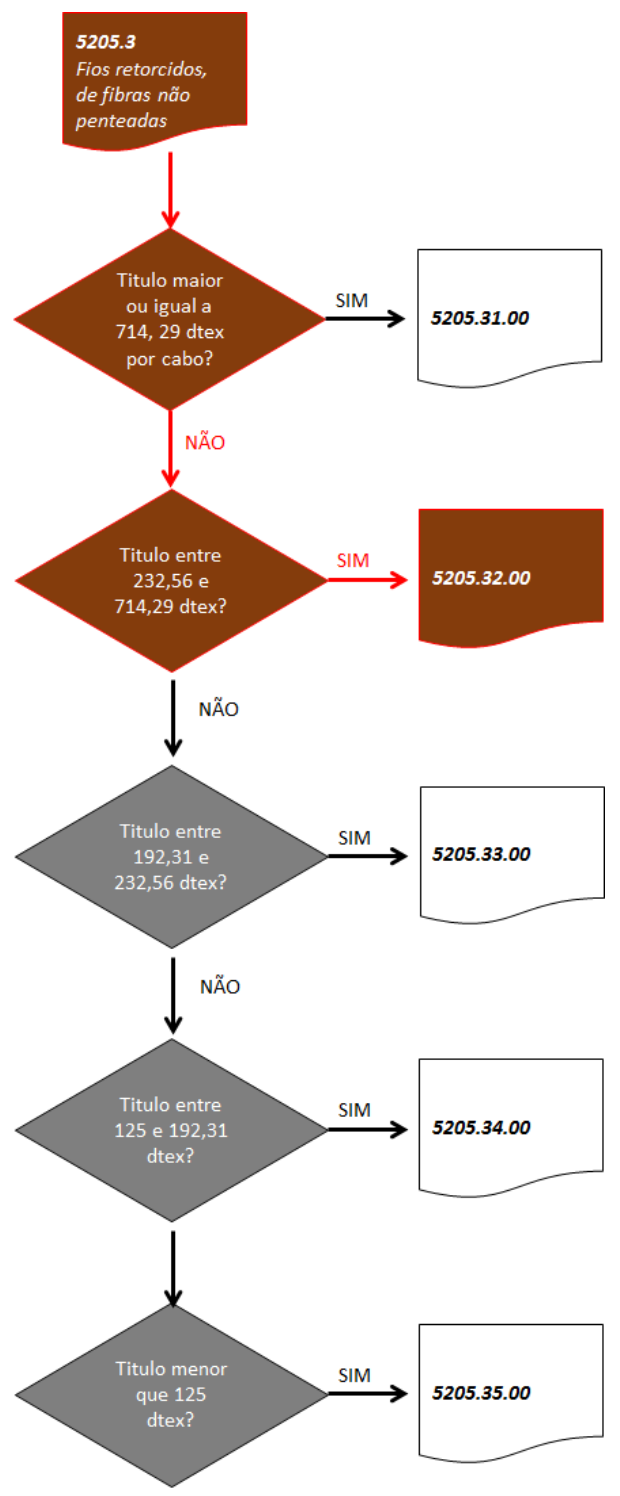

Fonte: Fabio Campos Fatalla, 2016

\subsection{TECIDO PLANO POLIÉSTER/ALGODÃO}

\subsubsection{Descrição do material}

O produto em análise trata-se de tecido plano tinto com $45 \%$ CO, 37\% PES e 18\% CV em ligamento tela com urdume de fio tinto $100 \%$ CO Ne 24/1 e trama PES / CV 67/33 $\% \mathrm{Ne} 20 / 1 \mathrm{cru}$. 


\subsubsection{ADE COANA 22:}

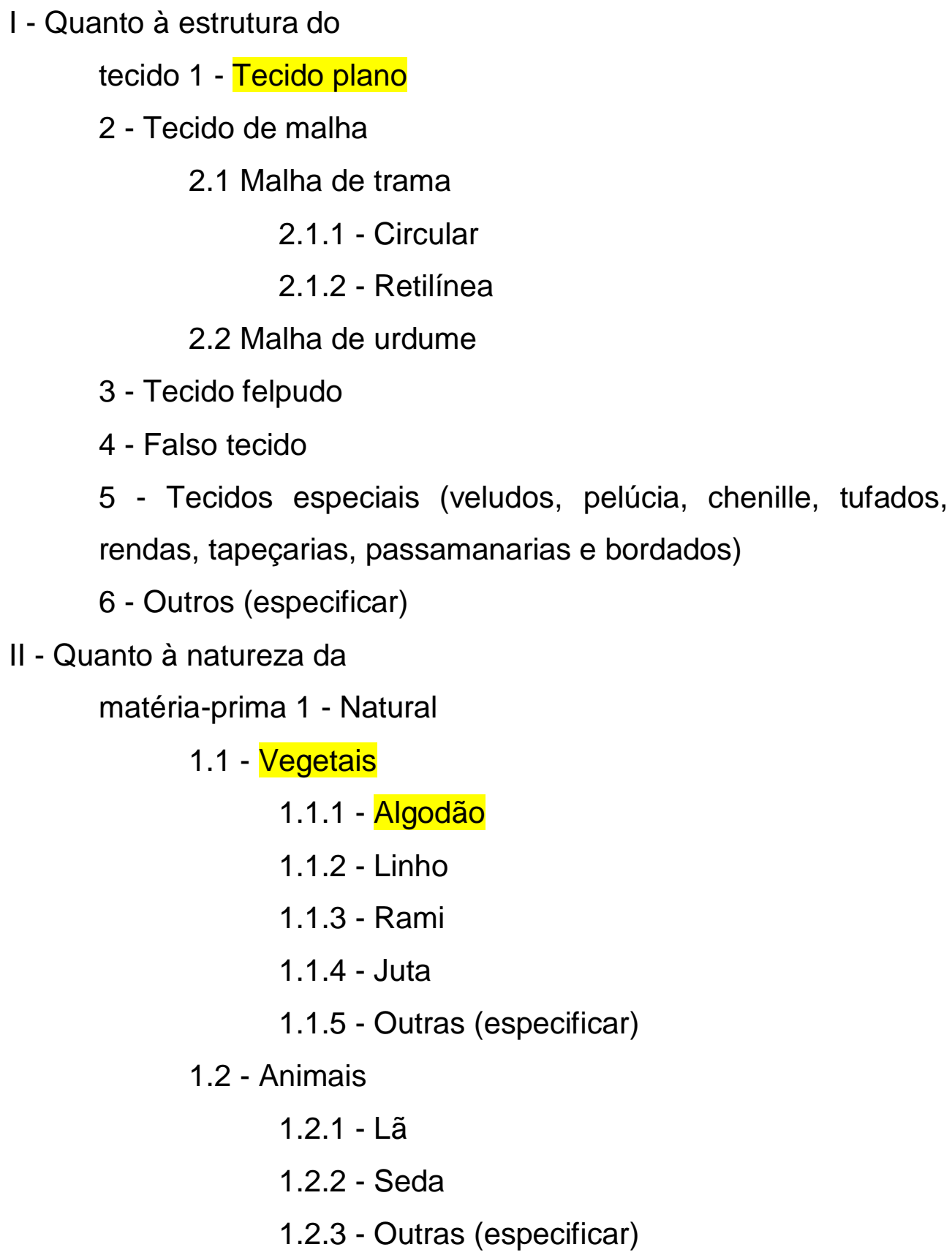

2 - Química

2.1 - Artificiais
2.1.1 - Raiom viscose
2.1.2 - Acetato
2.1.3 - Modal
2.1.4 - Liocel
2.1.5 - Cupro
2.1.6 - Outras (especificar) 


\section{2 - Sintéticas}

2.2.1 - Poliéster

2.2.2 - Poliamida

2.2.3 - Acrílico

2.2.4 - Elastano

2.2.5 - Polipropileno

2.2.6 - Outras

(especificar) 3 - Composição

Urdume: $100 \%$ algodão, $\mathrm{Ne} 24 / 1$

Trama: $67 \%$ poliéster e $33 \%$ viscose, $\mathrm{Ne} 20 / 1$

Total: $45 \%$ algodão $37 \%$ poliéster e $18 \%$ viscose

III - Quanto ao tipo de ligamento dos

fios 1 - Tela

2 - Sarja

3 - Cetim

4 - Outros (especificar)

IV - Quanto ao beneficiamento

1 - Tecido

cru 2 -

Tecido tinto

3 - Tecido branqueado

4 - Tecido de fios de diversas

cores 5 - Tecido estampado

6 - Outros (especificar)

IV - Quanto a outras informações

1 - Título dos fios (em dtex): urdume: 24,6 dtex e trama: 29,5

dtex 2 - Largura do tecido: 1,65 m

3 - Gramatura do tecido $\left(\mathrm{g} / \mathrm{m}^{2}\right): 220 \mathrm{~g} / \mathrm{m}^{2}$

\subsubsection{Fluxogramas}

\subsubsection{Fluxograma 1 - grupo de capítulos}

Como se trata de tecido plano, segundo o fluxo, o produto deve ser classificado nos capítulos 50 a 55 (figura 101): 
Figura 101 - Classificação de tecido - grupo de capítulos

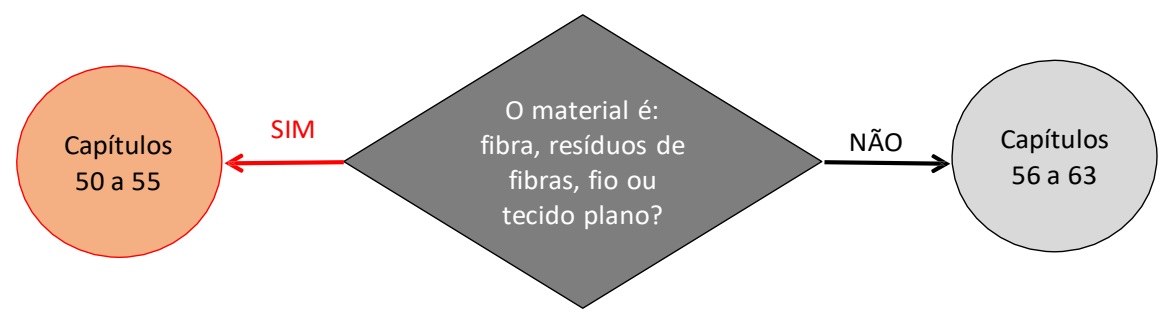

Fonte: Fabio Campos

Fatalla, 2016

\subsubsection{Fluxograma 2 - capítulo}

$\mathrm{Na}$ análise da matéria prima predominante a porcentagem de naturais (45\%) é menor do que a soma das artificiais e sintéticas (55\%). Nesse caso como essas são classificadas no mesmo capítulo devem ser tomadas em consideração conjuntamente. Em seguida, a matéria predominante é formada por fibras, portanto chega-se ao capitulo 55, conforme mostrado no fluxo da figura 102.

Figura 102 - Classificação de tecido - capítulo

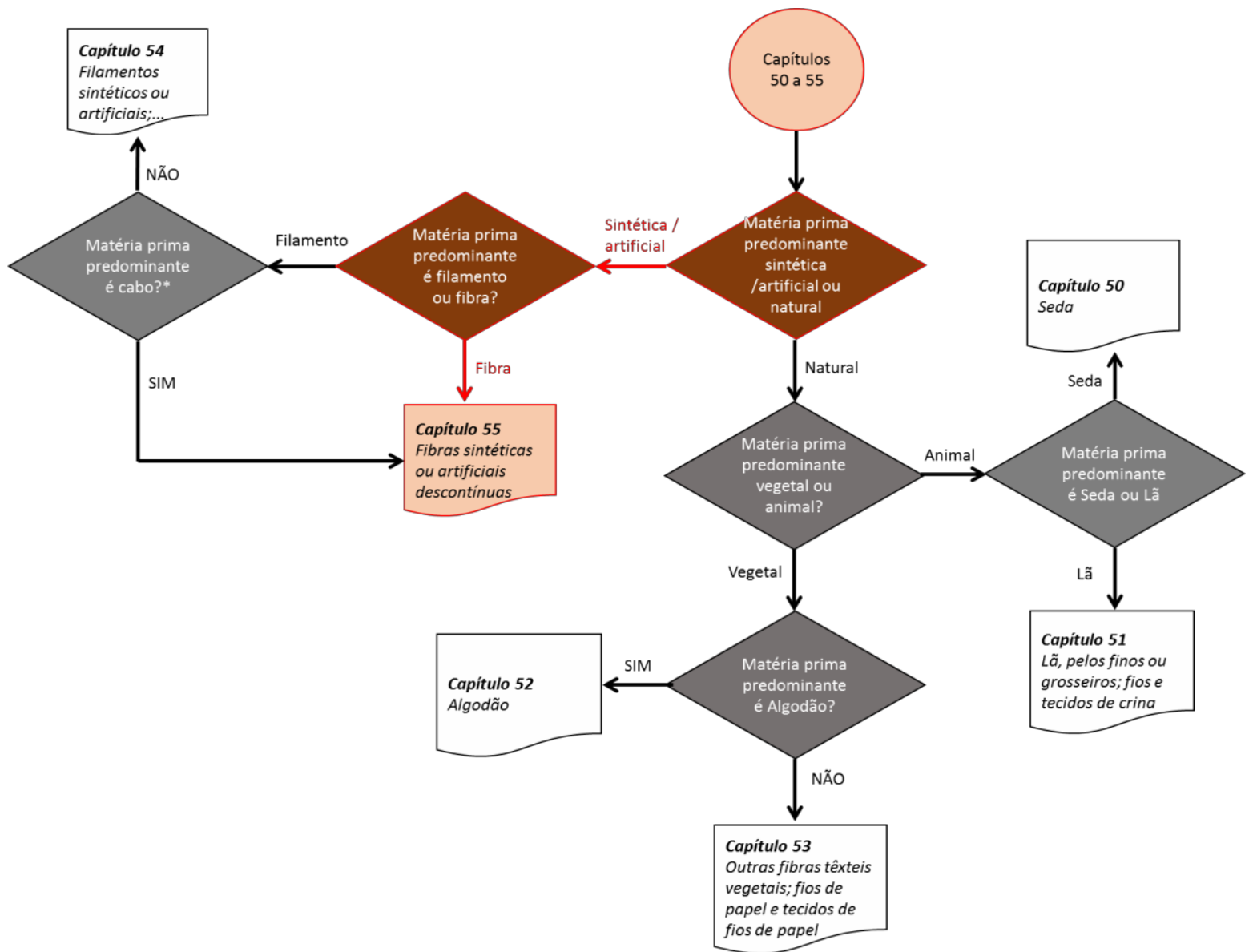

Fonte: Fabio Campos Fatalla, 2016 


\subsubsection{Fluxograma 3 - grupo de posições}

Conforme mostrado no fluxo da figura 103, como o produto trata-se de tecido, estará enquadrado nas posições 5513 a 5516.

Figura 103 - Classificação de tecido - grupo de posições

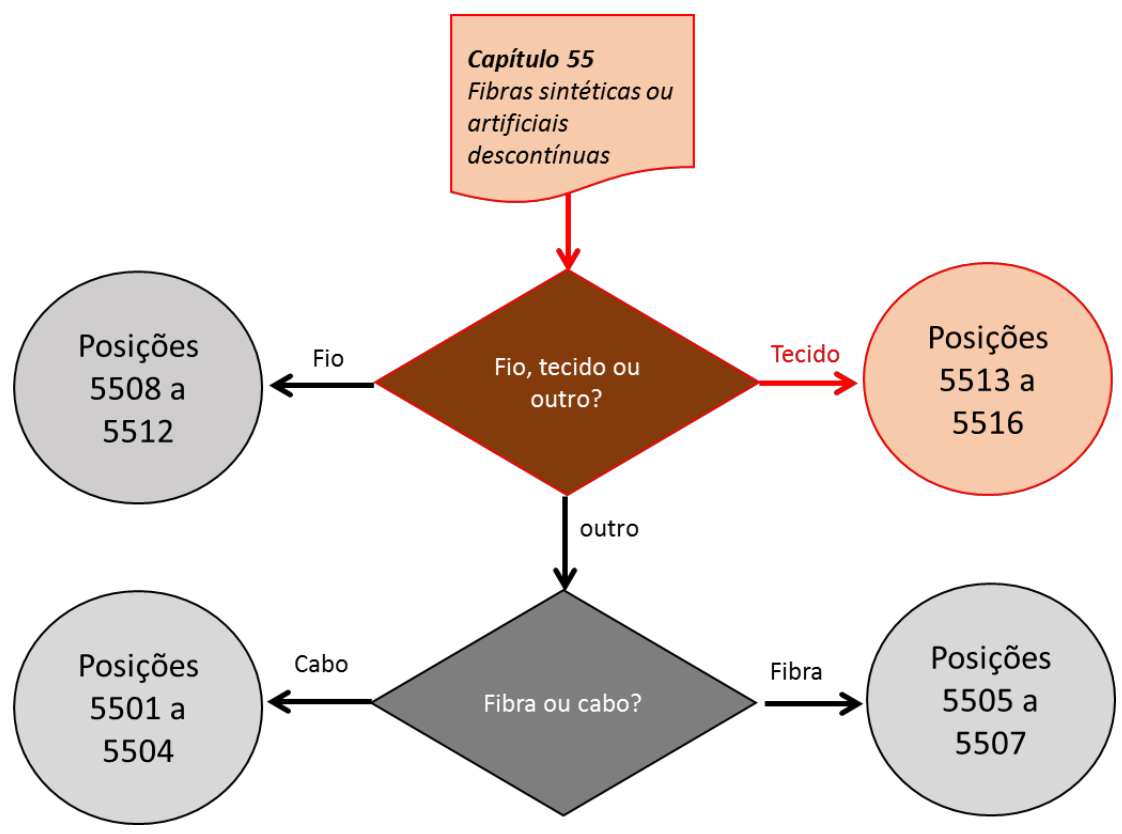

Fonte: Fabio Campos Fatalla, 2016

\subsubsection{Fluxograma 4 - posição}

Conforme mostrado no fluxo da figura 104, nesse caso tem-se em primeiro lugar que a porcentagem de fibras sintéticas descontínuas é menor do que $85 \%$ (37\%). A seguir verifica-se que nos tecidos as fibras sintéticas estão combinadas com algodão. E a seguir, considerando que a gramatura $\left(220 \mathrm{~g} / \mathrm{m}^{2}\right)$ é menor que $170 \mathrm{~g} / \mathrm{m}^{2}$, chega-se à posição 5514 . 
Figura 104 - Classificação de tecido - posição

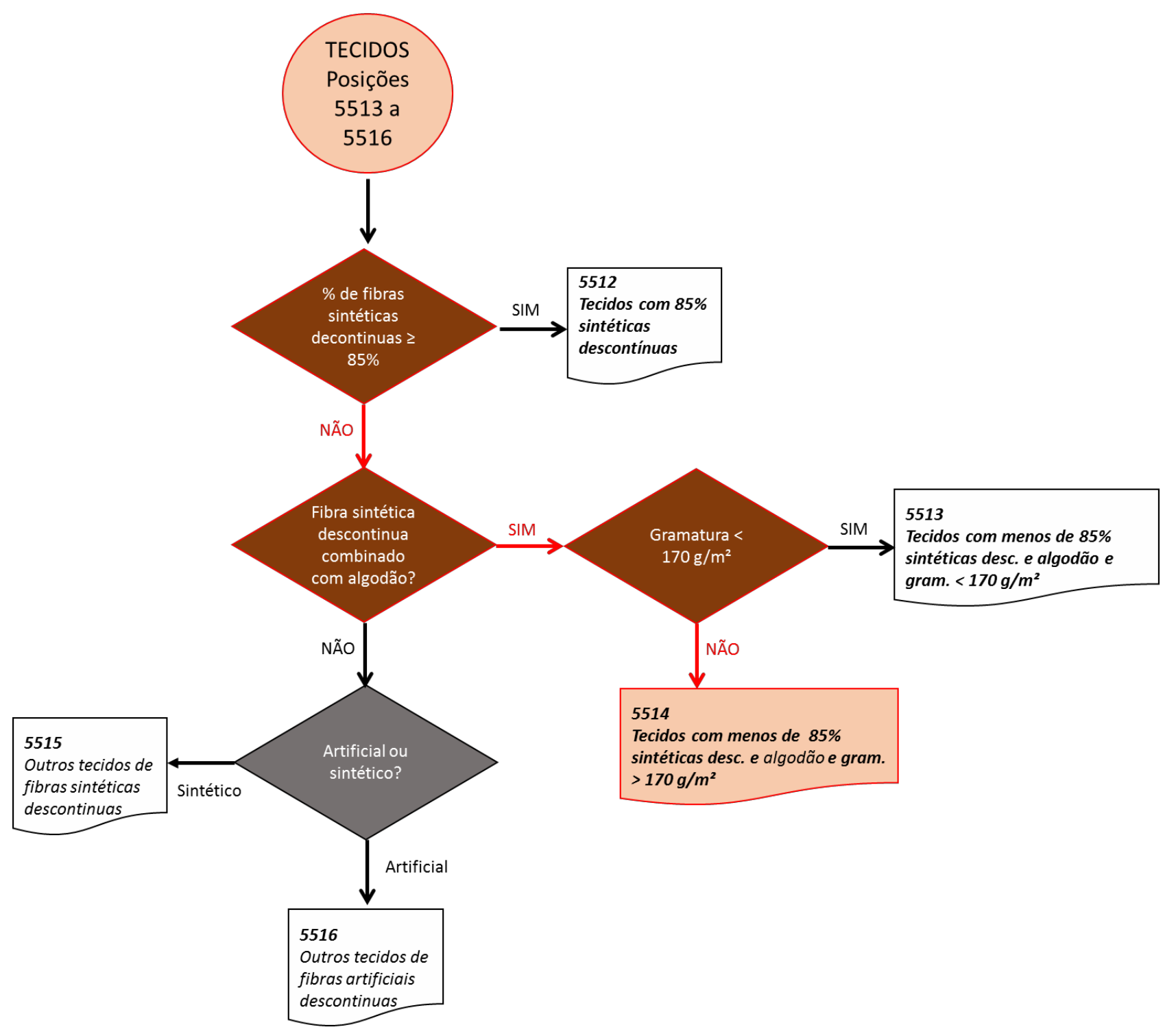

Fonte: Fabio Campos Fatalla, 2016

\subsubsection{Fluxograma 5 - primeiro algarismo da subposição}

Para definição do primeiro algarismo da subposição utiliza-se o fluxo da figura 105. Como trata-se de tecido tinto chega-se ao primeiro dígito da subposição: 5514.2. 
Figura 105 - Classificação de tecido - primeiro algarismo da subposição

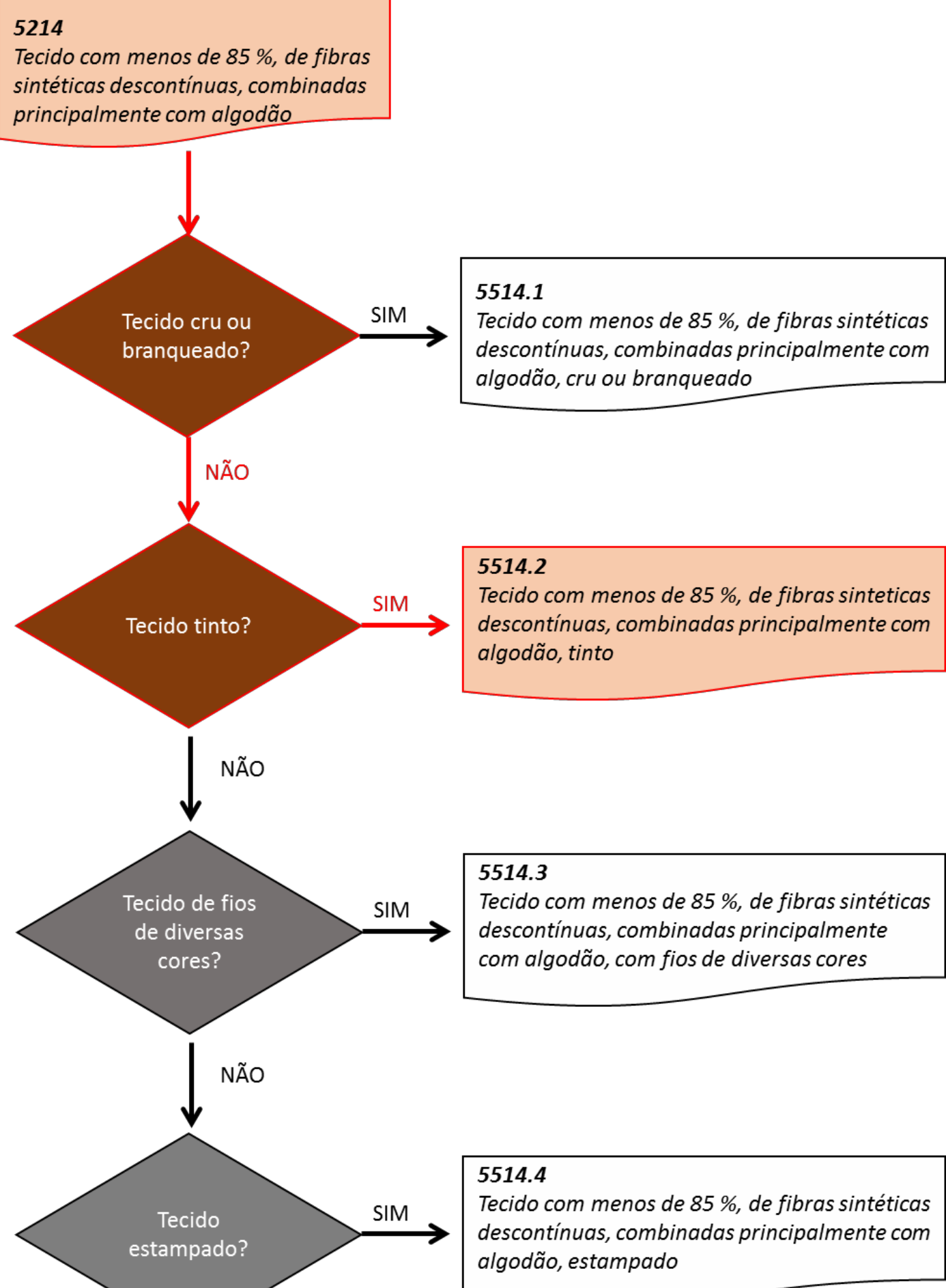

Fonte: Fabio Campos Fatalla, 2016 


\subsubsection{Fluxograma 6 - segundo algarismo da subposição}

Finalmente, o segundo algarismo da subposição é definido em função do ligamento conforme mostrado no fluxo da figura 106. Neste caso como trata-se de tecido em ligamento tela, chega-se ao segundo dígito da subposição: 5514.21.

Nesse caso como não há itens e subitens o artigo é classificado como 5514.21 .00

Figura 106 - Classificação de tecido - segundo algarismo da subposição

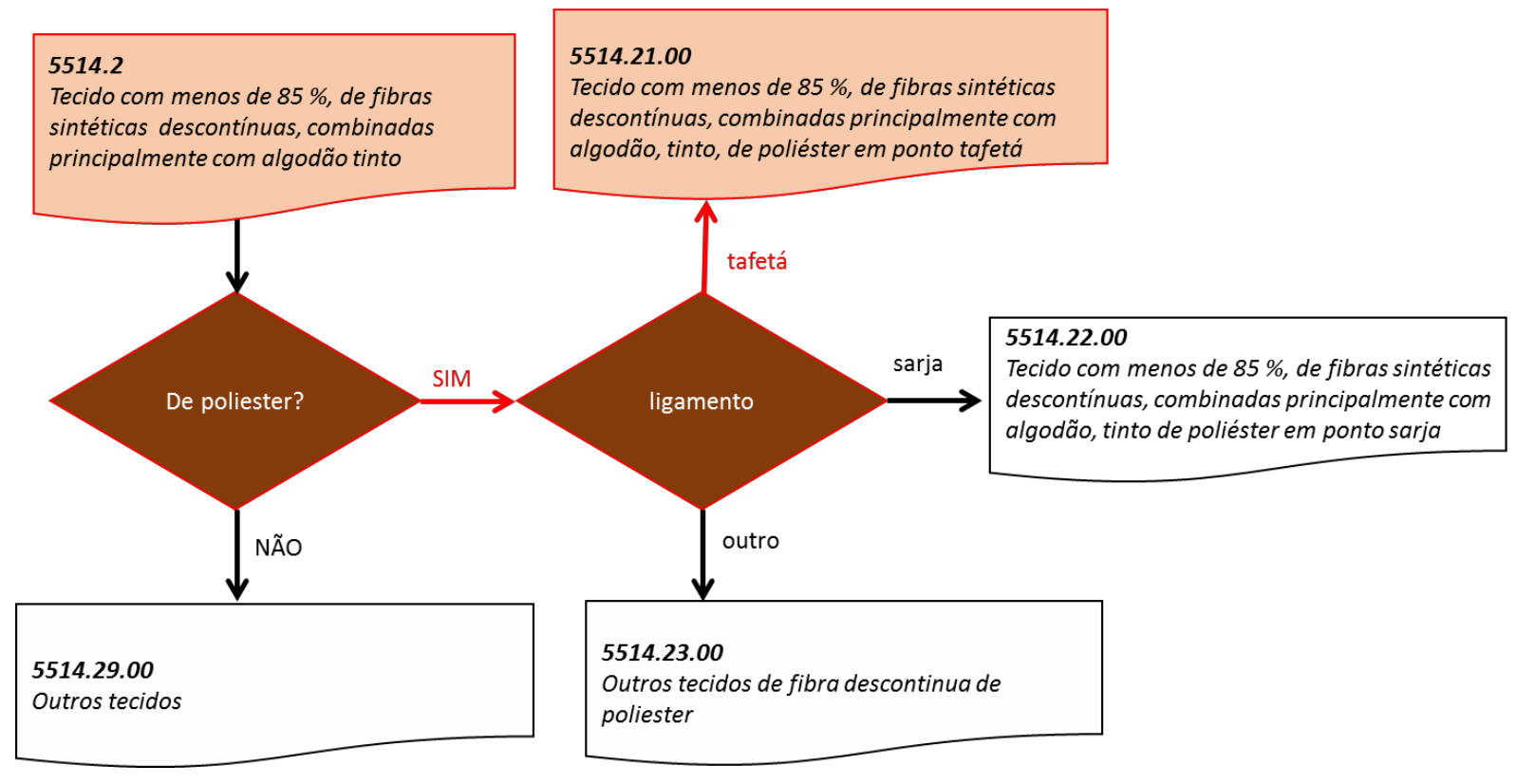

Fonte: Fabio Campos Fatalla, 2016

\subsection{TECIDO DE MALHA POR URDUME POLIAMIDA/ELASTANO}

\subsubsection{Descrição do material}

O produto em análise trata-se de tecido de malha por urdume estampado em poliamida / elastano com $140 \mathrm{~g} / \mathrm{m}^{2}$.

\subsubsection{ADE COANA 22:}

I - Quanto à estrutura do tecido

1 - Tecido plano 
2 - Tecido de malha

2.1 Malha de trama

2.1.1 - Circular

2.1.2 - Retilínea

2.2 Malha de urdume

3 - Tecido felpudo

4 - Falso tecido

5 - Tecidos especiais (veludos, pelúcia, chenille, tufados, rendas, tapeçarias, passamanarias e bordados)

6 - Outros (especificar)

II - Quanto à natureza da matéria-prima

1 - Natural

1.1 - Vegetais

1.1.1 - Algodão

1.1.2 - Linho

1.1.3 - Rami

1.1 .4 - Juta

1.1.5 - Outras (especificar)

1.2 - Animais

1.2.1 - Lã

1.2.2 - Seda

1.2.3 - Outras (especificar)

2 - Química

2.1 - Artificiais

2.1.1 - Raiom viscose

2.1.2 - Acetato

2.1.3 - Modal

2.1.4 - Liocel

2.1.5 - Cupro

2.1.6 - Outras (especificar)

2.2 - Sintéticas

2.2.1 - Poliéster

2.2.2 - Poliamida

2.2.3 - Acrílico 
2.2.4 - Elastano

2.2.5 - Polipropileno

2.2 .6 - Outras

(especificar) 3 - Composição

Poliamida: $85 \%$

Elastano: $15 \%$

III - Quanto ao tipo de ligamento dos

fios 1 - Tela

2 - Sarja

3 - Cetim

4 - Outros (especificar): charmeuse

IV - Quanto ao beneficiamento

1 - Tecido

cru 2 -

Tecido tinto

3 - Tecido branqueado

4 - Tecido de fios de diversas

cores 5 - Tecido estampado

6 - Outros (especificar)

IV - Quanto a outras informações

1 - Título dos fios (em dtex): Poliamida 44 dtex; Elastano: 44

dtex 2 - Largura do tecido: $1,80 \mathrm{~m}$

3 - Gramatura do tecido (g/m2): $140 \mathrm{~g} / \mathrm{m}^{2}$

\subsubsection{Fluxogramas}

\subsubsection{Fluxograma 1 - capítulo}

Inicialmente para determinação do capítulo recorre-se ao fluxograma 1 (figura 107). Neste caso, o produto em análise trata-se de tecido de malha por urdume, não é renda de crochet, etiqueta, emblema ou semelhante e também não é revestido ou recoberto. Portanto enquadra-se no capítulo 60. 
Figura 107 - Classificação de malha de urdume - capítulo

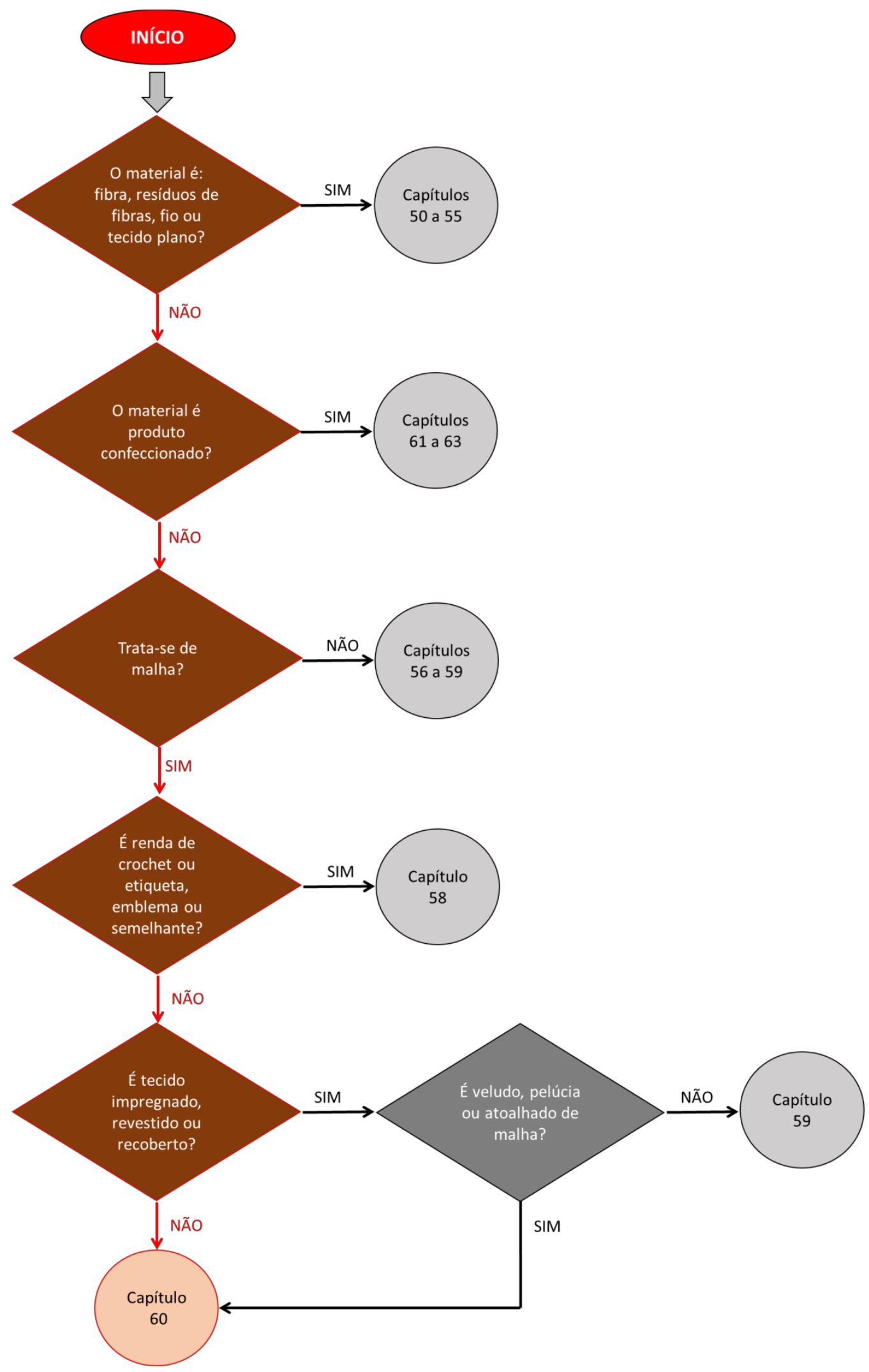

Fonte: Fabio Campos Fatalla, 2016 


\subsubsection{Fluxograma 2 - posição}

Para definição da posição utiliza-se o fluxo da figura 108, observando-se:

- $\quad$ Se o material é veludo, pelúcia ou atoalhado

- A largura (maior ou menor que $30 \mathrm{~cm}$ )

- A porcentagem de elastano (menor ou maior que $5 \%$ )

No caso do produto analisado trata-se de malha lisa, com largura 1,80 m (superior a $30 \mathrm{~cm}$ ) e 15\% de elastano (superior a 5\%). Portanto será enquadrada na posição 6004.

Figura 108 - Classificação de malha de urdume - posição

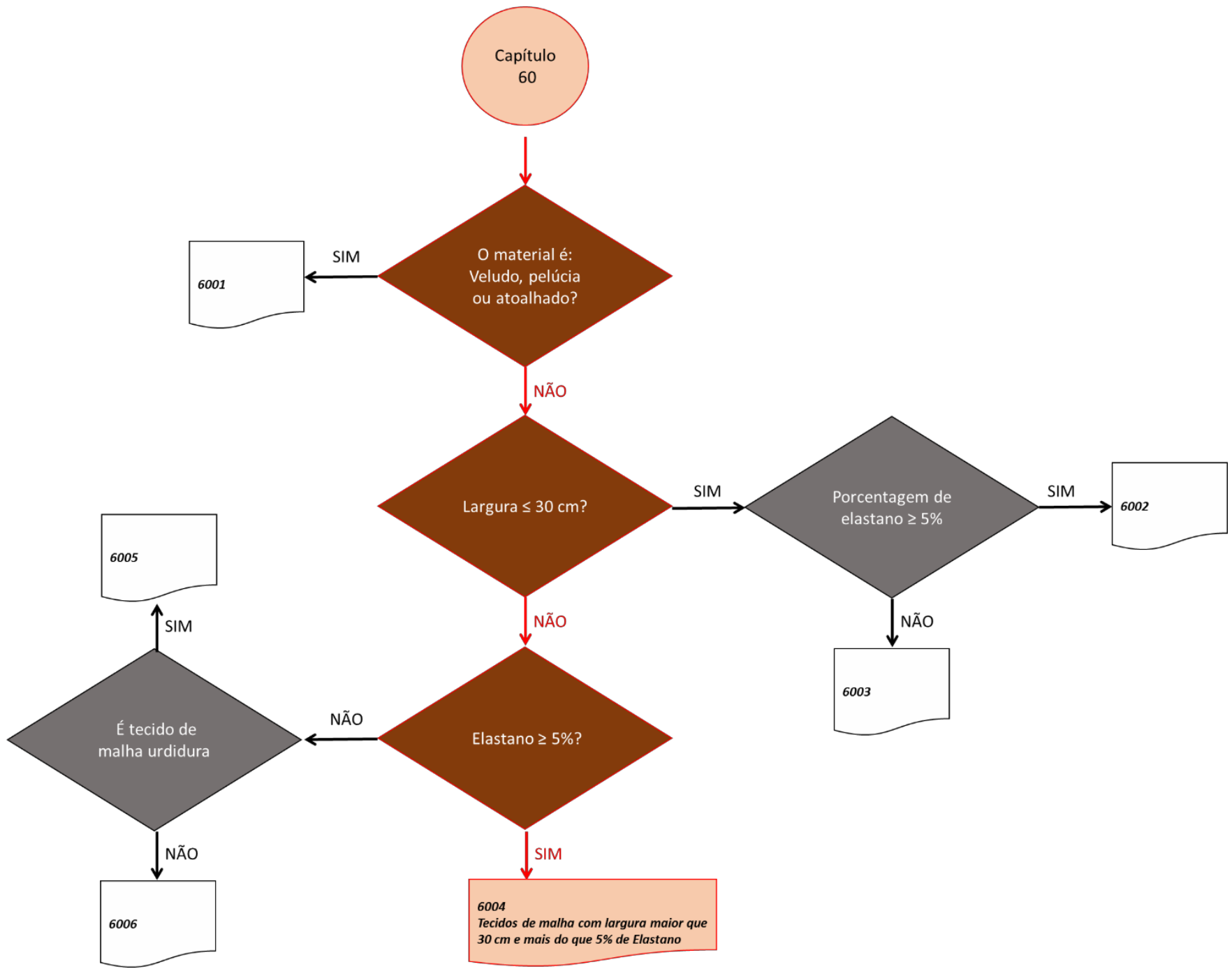

Fonte: Fabio Campos Fatalla, 2016 


\subsubsection{Fluxograma 3 - subposição}

Para determinação da subposição, conforme mostrado no fluxo da figura 109, deve-se verificar se o tecido, além do elastano, contém fios de borracha. Nesse caso, o produto em análise não contém fios de borracha enquadrando-se, portanto na subposição 6004.10.

Figura 109 - Classificação de malha de urdume - subposição

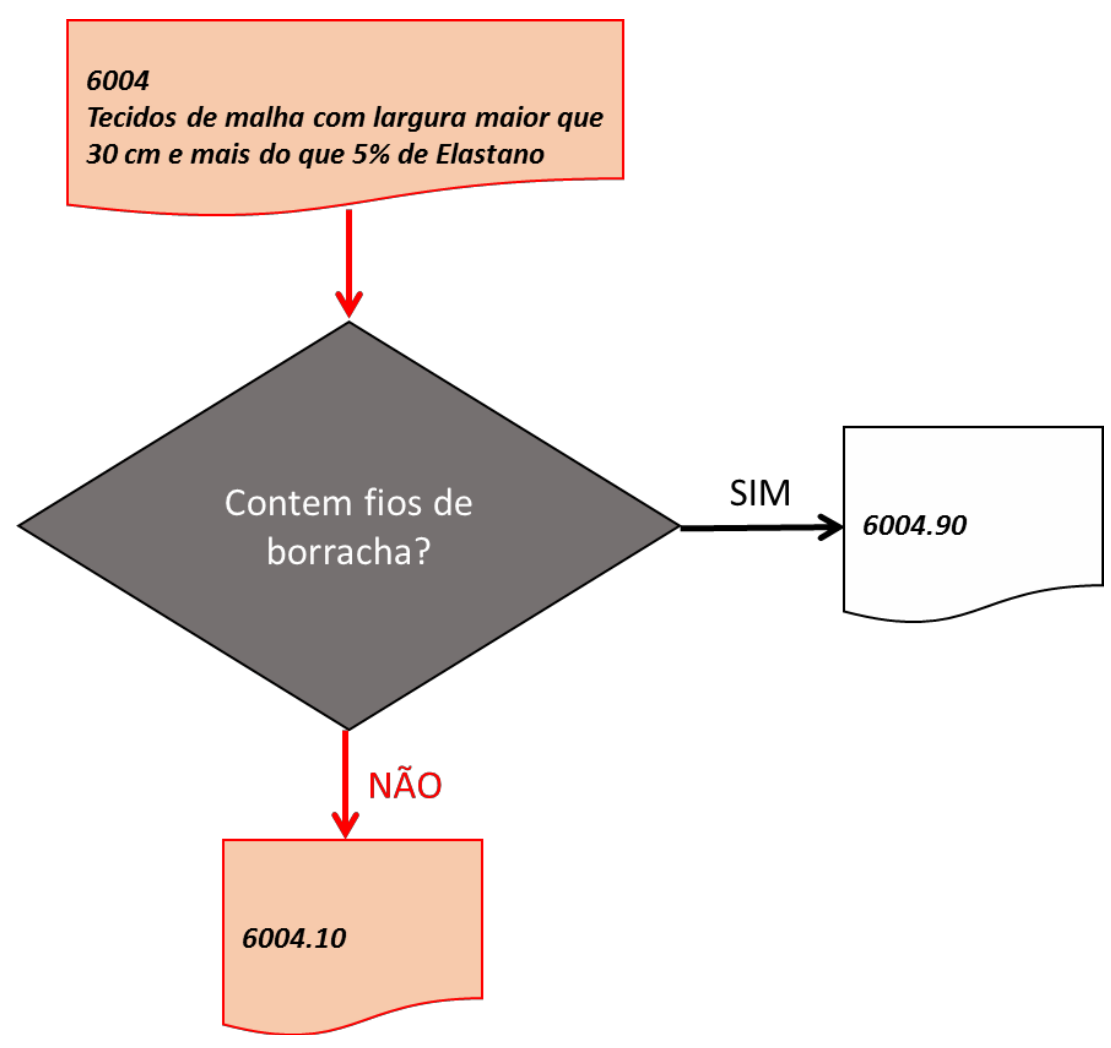

Fonte: Fabio Campos Fatalla, 2016

\subsubsection{Fluxograma 4 - item}

O dígito de item para esse tipo de produto leva em conta o tipo de matéria prima, conforme mostrado no fluxo da figura 110 . No caso do produto analisado, com tratase de matéria prima sintética (poliamida) chega-se ao item 6004.10.3. 
Figura 110 - Classificação de malha de urdume - subposição

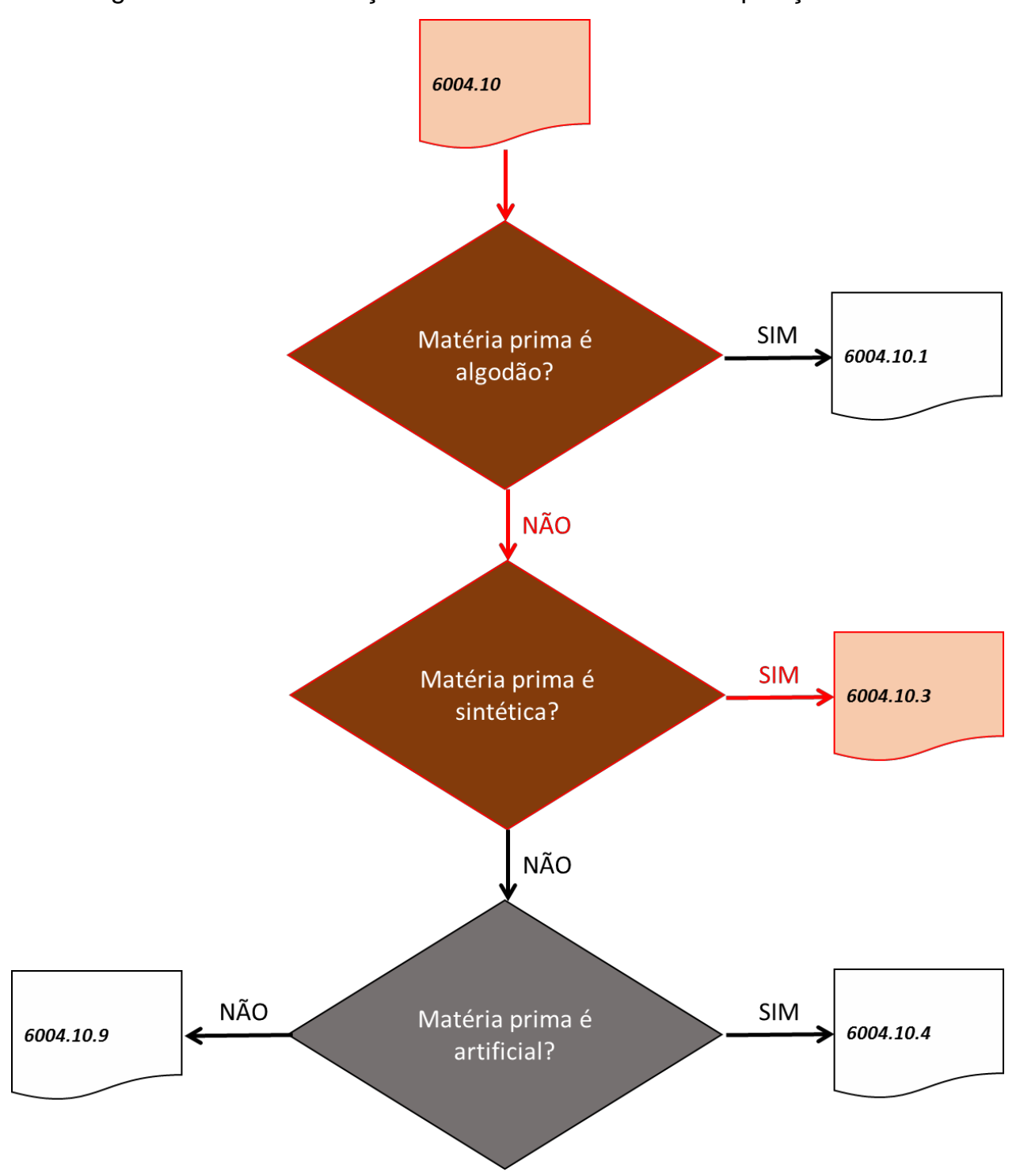

Fonte: Fabio Campos Fatalla, 2016

\subsubsection{Fluxograma 5 - subitem}

Para definição do subitem considera-se o tipo de beneficiamento da malha (fluxo da figura 111). Nesse caso trata-se de malha estampada e, portanto, chega-se à classificação final: 6004.10.34. 
Figura 111 - Classificação de malha de urdume - subposição

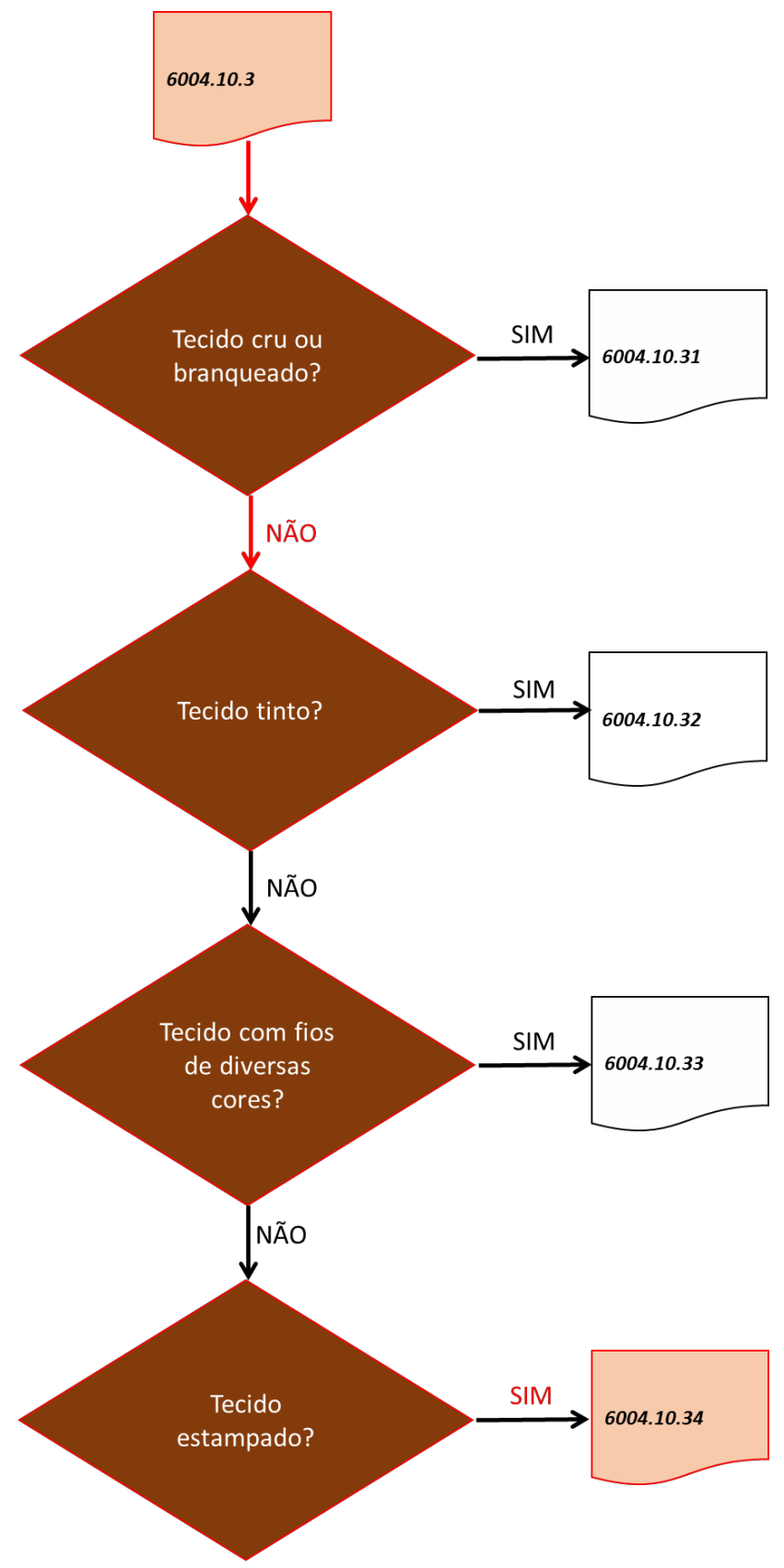

Fonte: Fabio Campos Fatalla, 2016

\subsection{VESTIDO DE TECIDO PLANO DE ALGODÃO}

\subsubsection{Descrição do material}

O produto em análise trata-se de vestido de malha $100 \%$ algodão. No caso de confeccionados não se aplica o ADE COANA 22. 


\subsubsection{Fluxogramas}

\subsubsection{Fluxograma 1 - capítulo}

Para determinação do capítulo utiliza-se o fluxograma 1 (figura 112). Neste caso, trata-se de produto confeccionado para vestuário, não é de malha e não é usado. Portanto enquadra-se no capítulo 62.

Figura 112 - Classificação de vestido de algodão - capítulo

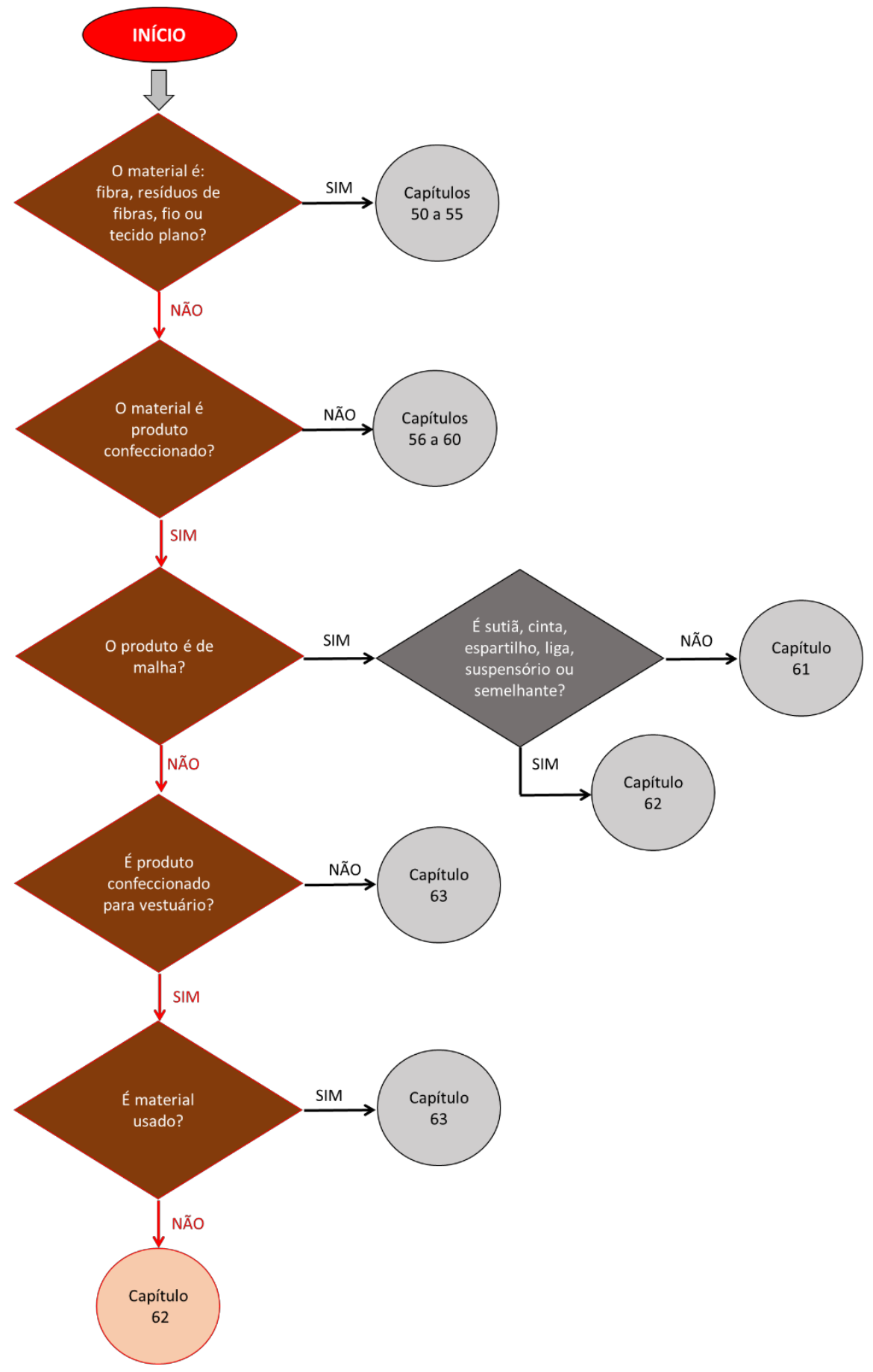

Fonte: Fabio Campos Fatalla, 2016 


\subsubsection{Fluxograma 2 - grupo de posições}

Para definição da posição utilizando o fluxo da figura 113, verifica-se inicialmente:

- Não utiliza falso tecido ou tecido impregnado ou revestido

- Não é vestuário de bebê

- Não é acessório de vestuário

- Não é abrigo esportivo, sunga, maio, etc.

- Não é sutiã, espartilho, liga, etc.

- Não é vestuário masculino

Nesse caso chega-se às posições possíveis: 6202, 6204, 6206, 6208.

\subsubsection{Fluxograma 3 - posição}

Para definição final da posição (fluxo 3 - figura 114) verifica-se o conjunto de peças de peça. Nesse caso está incluído na posição 6204: Tailleurs, conjuntos, blazers, vestidos, saias, saias-calças, calças, jardineiras, bermudas e shorts (calções) (exceto de banho), de uso feminino.

\subsubsection{Fluxograma 4 - primeiro dígito da subposição}

Utilizando o fluxo 4 (figura 115), define-se o primeiro dígito da subposição que considera o tipo de peça. Nesse caso, 6204.4 pois trata-se de vestido.

\subsubsection{Fluxograma 5 - segundo dígito da subposição}

O segundo dígito da subposição leva em conta a matéria prima predominante, conforme pode ser observado no fluxo da figura 116. Nesse caso a matéria prima predominante é algodão e, como essa classificação não tem itens ou subitens, chega- se à classificação final 6204.42.00. 
Figura 113 - Classificação de vestido de algodão - grupo de posições

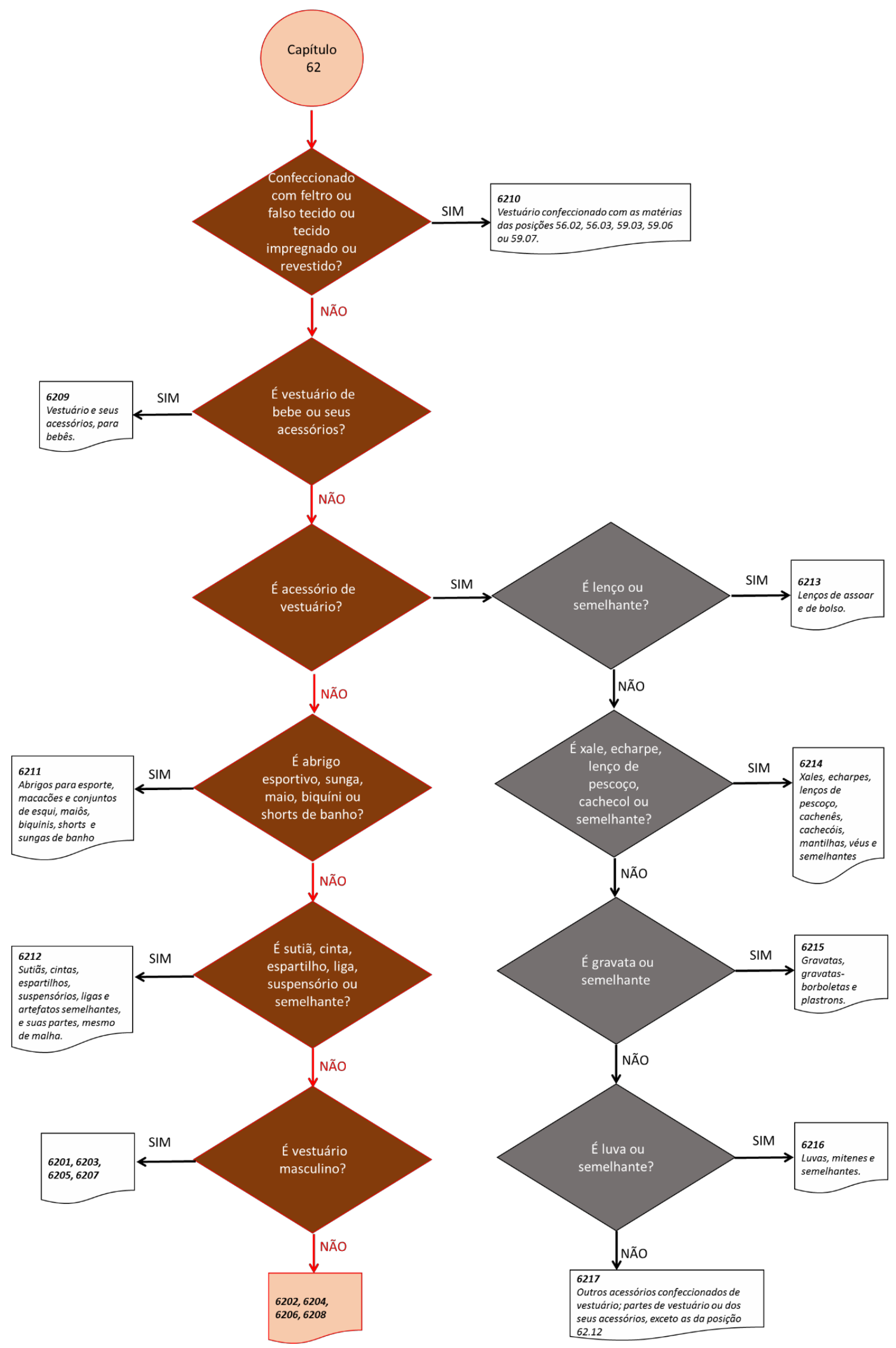

Fonte: Fabio Campos Fatalla, 2016 
Figura 114 - Classificação de vestido de algodão - posição

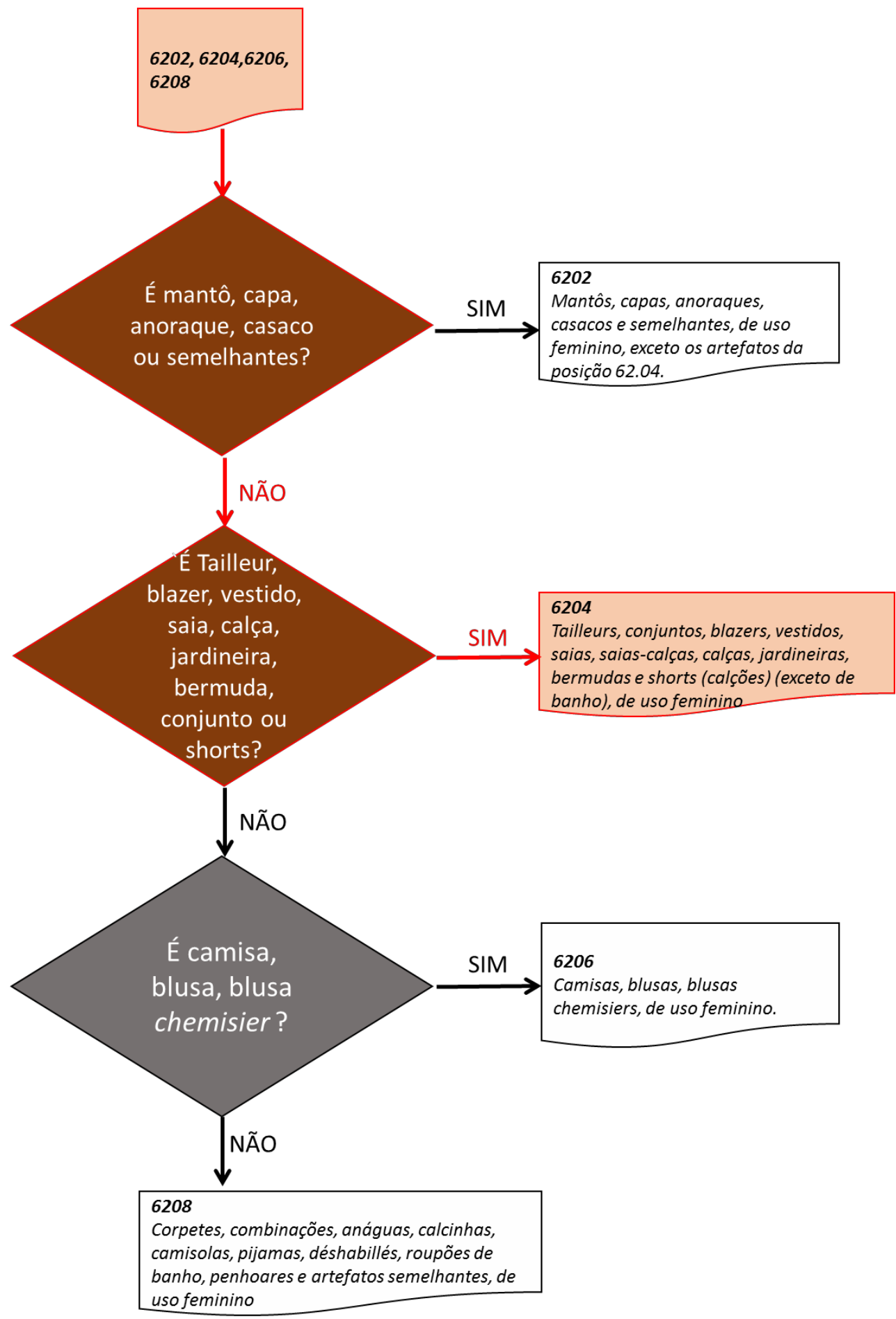

Fonte: Fabio Campos Fatalla, 2016 
Figura 115 - Classificação de vestido de algodão - primeiro dígito da subposição

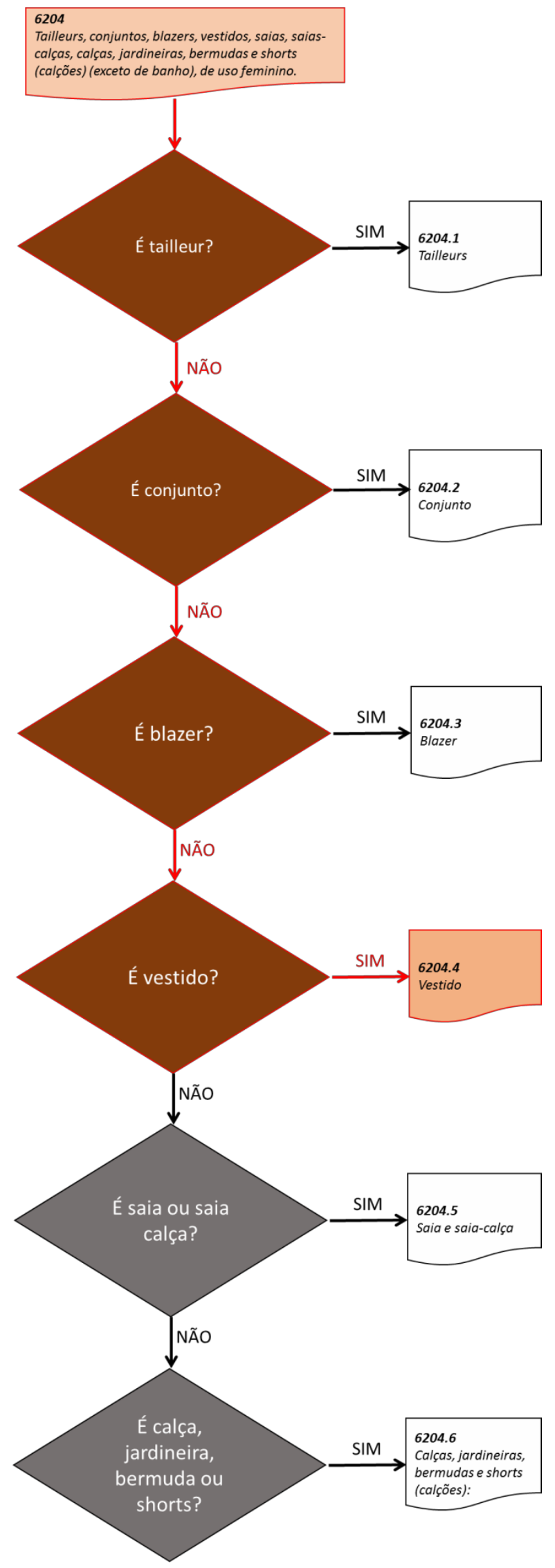

Fonte: Fabio Campos Fatalla, 2016 
Figura 116 - Classificação de vestido de algodão - segundo dígito da subposição

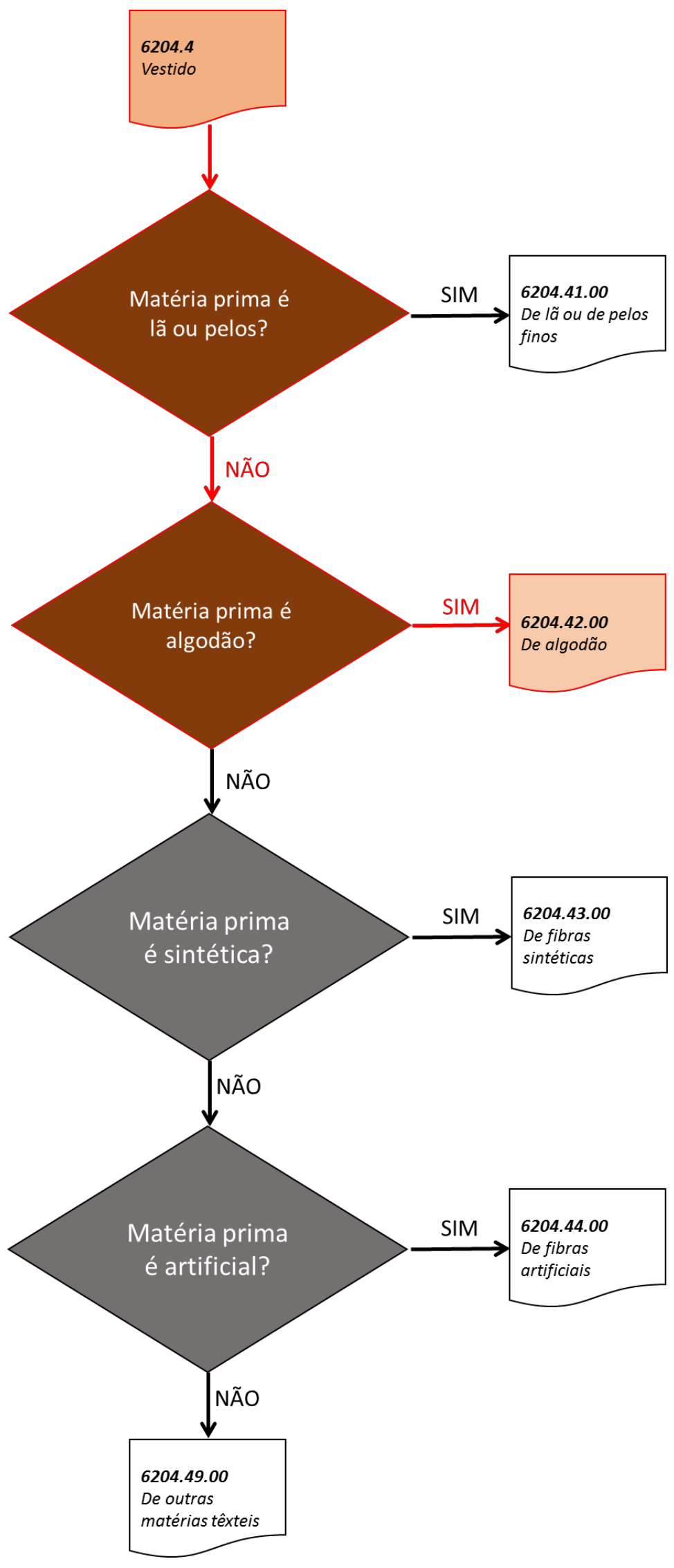

Fonte: Fabio Campos Fatalla, 2016 


\section{CONCLUSÃO}

Foram estudados os critérios para classificação de mercadorias e desenvolvida uma metodologia proposta para a classificação de mercadorias têxteis na NCM consiste em:

- Verificar e levantar os pontos chaves de diferenciação contidos na descrição dos produtos

- Analisar e descrever os produtos a serem classificados, focando especialmente esses pontos chaves, de acordo com o ADE COANA 22

- Construir fluxogramas lógicos de decisão baseado nos pontos chaves levantados e nas regras de classificação.

- Submeter o material ao fluxograma lógico de decisão e determinar sua classificação.

Essa metodologia foi aplicada em quatro produtos distintos

- Fio $100 \%$ algodão

- Tecido plano algodão/poliéster/viscose

- Tecido de malha por urdume poliamida/elastano

- Vestido de tecido plano algodão

Observou-se que, em todos os casos, a metodologia permitiu a correta classificação do material sem dificuldades, desde que os pontos chaves estivessem corretamente caracterizados nos produtos.

Com isso demonstra-se que a metodologia pode ser difundida e empregada na classificação de materiais têxteis. O segredo para permitir uma correta classificação através da metodologia proposta está baseado em quatro pontos principais:

- Compreender os princípios da classificação fiscal de mercadorias e suas regras

- Compreender as características que são pontos focais nas classificações dos diversos materiais

- Estabelecer critérios de decisão nos fluxogramas baseados nessas características 
- Analisar correta e exaustivamente os materiais a serem classificados no que diz respeito à essas características

Como sugestões para trabalhos futuros é possível citar o desenvolvimento de algoritmos computacionais e, consequentemente, softwares que permitam determinar a classificação fiscal de um produto baseado em inputs solicitados ao usuário. Essas informações seriam oriundas e da análise de caracterização dos materiais e baseadas naquelas características que são pontos chaves de diferenciação e decisão na análise da classificação. 


\section{REFERÊNCIAS}

ADE COANA 22/05 - ADE - Ato declaratório executivo coordenador geral do sistema aduaneiro - COANA no 22, DOU de 27.9.2005

ANTERO, S. A. Articulação de políticas públicas a partir dos fóruns de competitividade setoriais: a experiência recente da cadeia produtiva têxtil e de confecções. RAP. Rio de Janeiro, 2006.

ABNT NBR 12744/1992 - Fibras têxteis - Classificação, 1992

ARAÚJO, M., e CASTRO, E.M.M., Manual de Engenharia Têxtil. Vol.1 e 2, Fundação Calouste Gulbenkian, Lisboa, 1986.

BARBOSA, M. Z.; NOGUEIRA JÚNIOR, S. Reestruturação da cadeia de produção de têxteis no Brasil e seus reflexos na cotonicultura. Anais do XXXVIII Congresso Brasileiro de Economia e Sociologia Rural - SOBER. Rio de Janeiro, 2000.

BIZELLI, J. S. Classificação fiscal de mercadorias, Aduaneiras, São Paulo, 2006

BROGINI, G. Tributação e benefícios fiscais no comércio exterior. $20^{a}$ edição. Curitiba: Editora Ibpex, 2008.

CAMPOS, M. J. C.; MOUTINHO, L. M. G. e CAMPOS, L. H. R. Reestruturação Produtiva e Qualidade do Emprego Formal na Indústria Têxtil: um estudo comparativo entre as regiões Nordeste e Sul. - Biblioteca SEBRAE, 2014.

CIESP; Manual básico sobre nomenclatura e classificação de mercadorias. 2007

COOK, J.G. Handbook of Textile Fibres: Man-Made Fibres, Volume 1. Woodhead Publishing. New York,1984 
COSTA NETO, P. L. e GUSMÃO, N. N. Uma visão da qualidade na cadeia têxtil em empresas de pequeno e médio porte. IV Congresso Nacional de Excelência em Gestão. 2008.

COUTINHO, L.; HIRATUKA, C. e SABBATINI, R. O desafio da construção de uma inserção externa dinamizadora. Rio de Janeiro: UFRJ, 2003

DALSTON, C. O. Classificando Mercadorias: Uma abordagem didática da Ciência da Classificação de Mercadorias. São Paulo: Lex Editora, 2005.

DULCI, O. S., Guerra Fiscal, desenvolvimento desigual e relações federativas no Brasil. Revista de Sociologia e Política, № 18: 95-107, JUN 2002.

ELALI, A. Incentivos fiscais, neutralidade da tributação e desenvolvimento econômico: a questão da redução das desigualdades regionais e sociais SISNET - Aduaneiras, 2013

FRANCISCHINI, A. S. N. e AZEVEDO, P. F. Estratégias das empresas do setor calçadista diante do novo ambiente competitivo: análise de três casos. G\&PGestão e Produção, 2009.

GARCIA, R. Uma Análise do processo de desconcentração regional nas indústrias têxtil e de calçados e a importância dos sistemas locais de produção. Anais do XIII Encontro Regional de Economia da ANPEC e Fórum BNB de Desenvolvimento. 2001.

GORINI, A. P. F. Panorama do setor têxtil no Brasil e no mundo: reestruturação e perspectivas. BNDES Setorial, Rio de Janeiro, n. 12, 2000.

GORINI, A. P. F. e SIQUEIRA, S. H. G. Complexo têxtil brasileiro. AO1/GESET2, 2002.

GUILLÉN, J. G., Microfibras. Barcelona: UPC, 2001. 
HAGUENAUER, L.; BAHIA, L. D.; CASTRO, P. F. e RIBEIRO, M. B. Evolução das Cadeias Brasileira na Década de 90. IPEA - Instituto de Pesquisa Econômica Aplicada. Brasília, 2001.

IEMI - Instituto de Estudos e Marketing Industrial, Brasil Têxtil - Relatório Setorial da Indústria Têxtil Brasileira, 2014

KELLER, P. F., Economia global e novas formas de organização na produção na cadeia têxtil - confecção. Revista Universidade Rural, Série. Ciências Humanas. Vol. 24, 2002.

KON, A. e COAN, D. C., Transformações na indústria têxtil brasileira: a transição para a modernização. Revista de Economia Mackenzie, v. 3, n. 3, 2005.

LORD, P. R. Handbook of yarn production. Woodhead Publishing. Cambridge, 2003

MALUF. A e KOLBE. W., Manual de dados técnicos para a Indústria Têxtil, IPT, São Paulo, 2003

MARCOVITCH, J.; SBRAGIA, R.; STAL, E. e TERRA, J. C. C. Inovação tecnológica e incentivos fiscais. Revista de Administração. São Paulo, 1991.

MASSUDA, E. M. Transformações recentes da indústria têxtil brasileira (1992-1999). Acta Scientiarum. Maringá, 2002.

NESH - Notas Explicativas do Sistema Harmonizado de Designação e de Codificação de Mercadorias. Instrução Normativa RFB oㅜ 807. 2008

OLIVEIRA, F.R. A complexa ciência da Classificação Fiscal de Mercadorias e o clássico exemplo do parafuso. Thomson Reuters Global Resources. 2009

OLIVEIRA, M.H.; MEDEIROS, L. A. Investimentos necessários para a modernização do Setor Têxtil. BNDES Setorial. Rio de Janeiro: BNDES, n.3, 1996. 
SEGAL, W. AF Encyclopedia of Textiles, Prentice-Hall. Minnesota. 1972.

SIFUENTES, M. C. O sistema harmonizado de designação e codificação de mercadorias. Revista da Associação Mineira de Direito e Economia (AMDE), 2013.

SITE: Portal ALICEWEB - Sistema de Análise de Informações de Comércio Exterior, http://aliceweb.mdic.gov.br, acesso em 10/05/16.

SPENCER, D., Knitting technology, Pergamon Press, 3aed, London, 2001.

VASCONCELOS, F.B. Introdução à malharia. Centro Universitário FEI. Apostila não publicada. 2015

WALCZAK, Z.K. Processes of Fiber Formation. ELSEVIER. Oxford, 2002 